EFFECTS OF PRESENT AND PROJECTED GROUND-WATER WITHDRAWALS

ON THE TWIN CITIES AQUIFER SYSTEM, MINNESOTA

by M. E. Schoenberg

U.S. GEOLOGICAL SURVEY

Water-Resources Investigations Report 90-4001

Prepared in cooperation with the

MINNESOTA DEPARTMENT OF NATURAL RESOURCES and METROPOLITAN COUNCIL OF THE TWIN CITIES

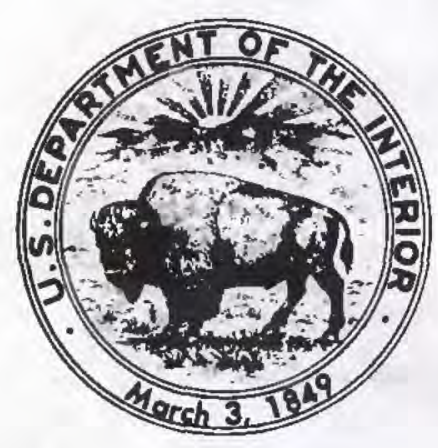

St. Paul, Minnesota 
DEPARTMENT OF THE INTERIOR

MANUEL LUJAN, JR., Secretary

U.S. GEOLOGICAL SURVEY

Dallas L. Peck, Director

For additional information write to:

District Chief

U.S. Geological Survey

702 Post Office Building

St. Paul, Minnesota 55101
Copies of this report can be purchased from:

U.S. Geological Survey Books and Open-File Reports Section Federal Center

Box 25425

Denver, Colorado 80225 


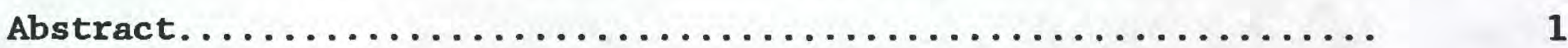

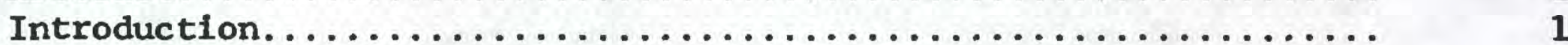

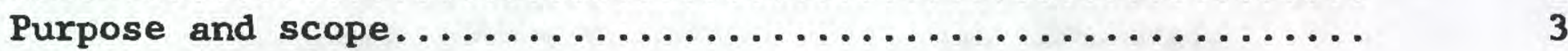

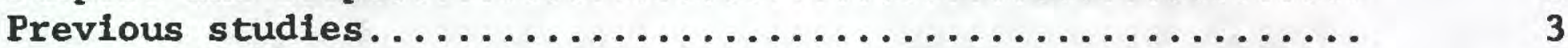

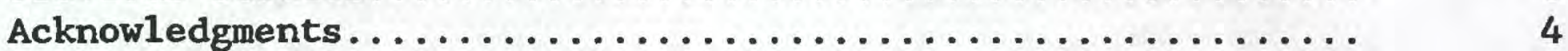

General description of aquifer system................... 4

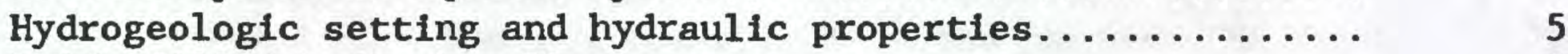

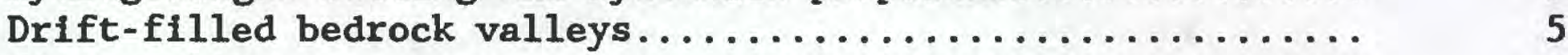

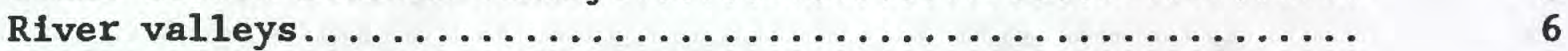

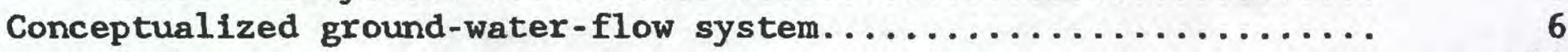

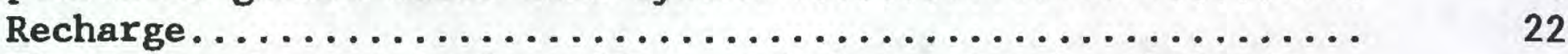

Flow through principal aquifers and change in the altitude

of their potentiometric surfaces..................... 24

Prairie du Chien-Jordan aquifer................... 25

Mount Simon-Hinckley aquifer.................. 30

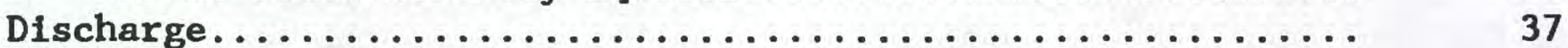

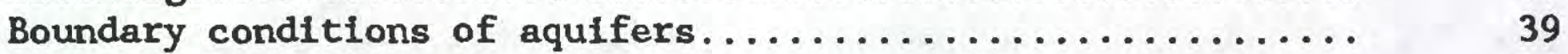

Conceptual model................................ 42

Effects of present ground-water withdrawals................ 42

Mathematical basis for the numerical model............... 43

Finite-difference grid....................... 44

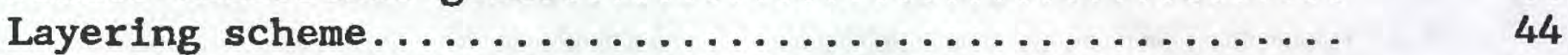

Discretization of data...................... 57

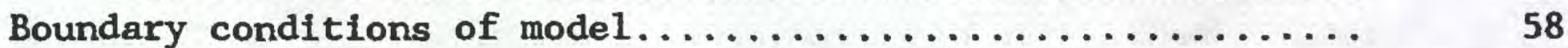

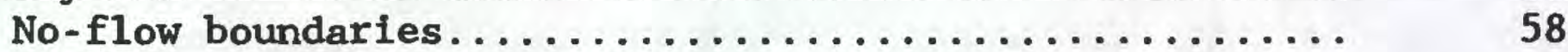

Head-dependent flux boundaries................. 58

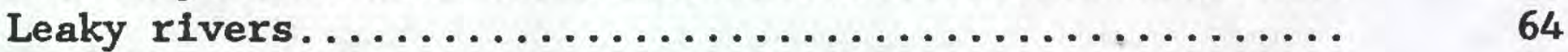

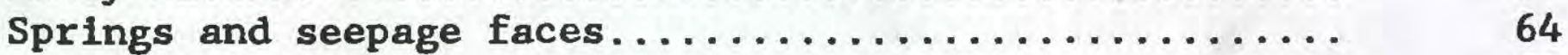

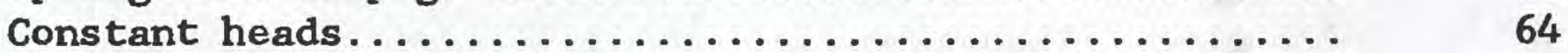

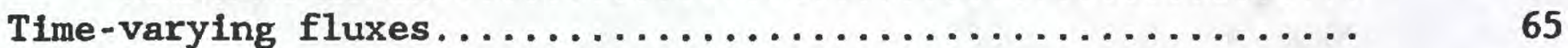

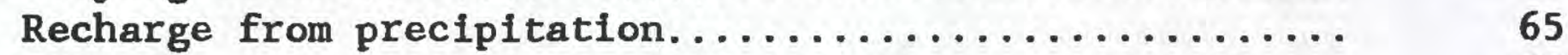

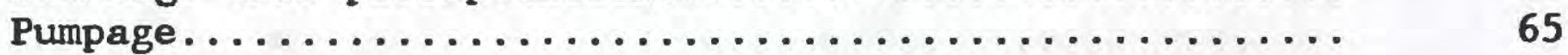

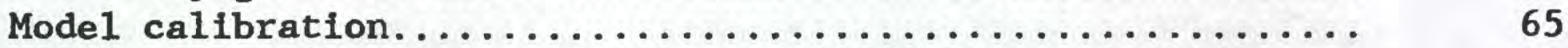

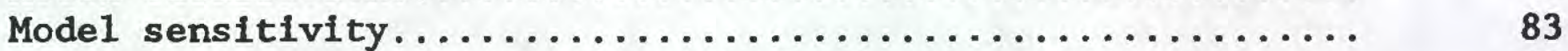

Effects of projected ground-water withdrawals............. 83

Projected ground-water use............................. 87

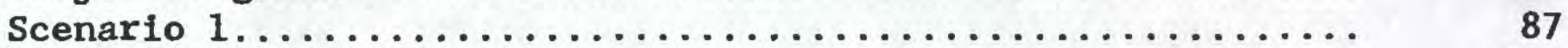

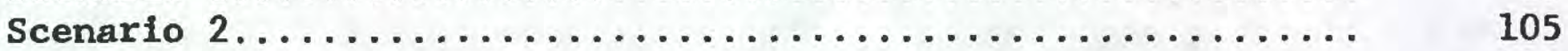

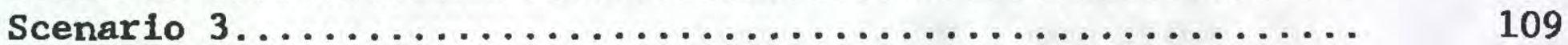

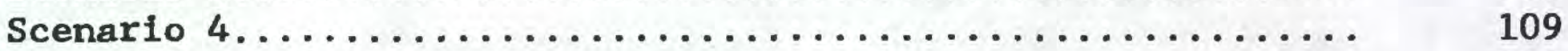

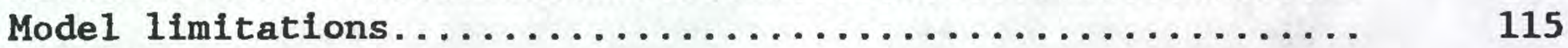

Need for future studies............................. 119

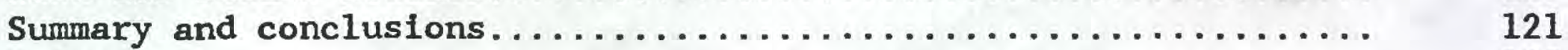

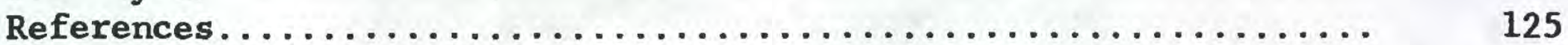

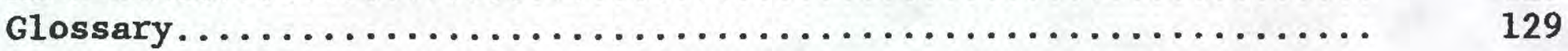


Appendixes A: Calculation of transmissivity and vertical leakage coefficients for heterogeneous hydrogeologic materials in a model cell.......

B: Withdrawals simulated at each cell for all simulations........................... 135

C: True differences between model-calculated and observed heads (residuals) for model calibra-

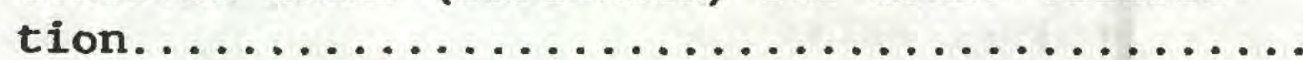

D: Absolute differences between model-calculated and observed heads (residuals) for model calibration.

\section{ILLUSTRATIONS}

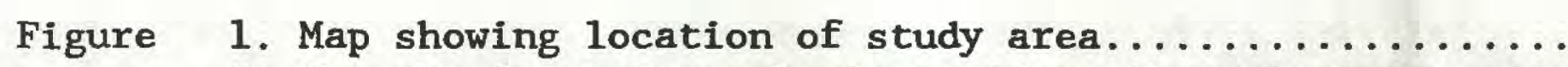

2. Map showing hydrogeologic sections through study area.

3-4. Maps showing thickness of the:

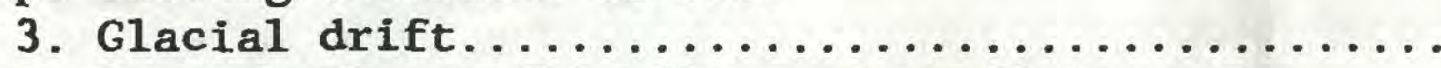

4. Decorah-Platteville-Glenwood confining unit.....

5. Map showing the composite thickness of the St. Peter aquifer and lower St. Peter confining unit........ 6-10. Maps showing thickness of the:

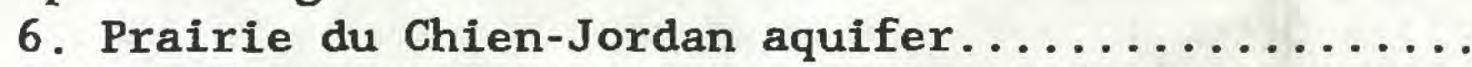

7. St. Lawrence-Franconia confining unit..........

8. Ironton-Galesville aquifer...............

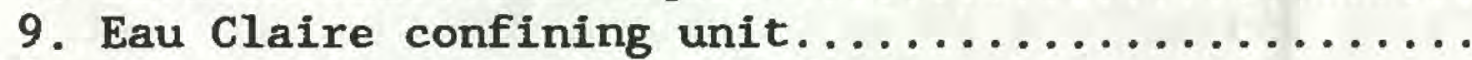

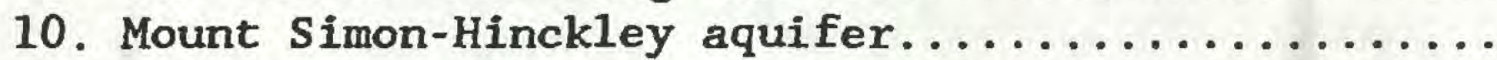

11-15. Maps showing:

11. Configuration of the bedrock surface..........

12. Distribution of types of glacial deposits.........

13. Predevelopment potentiometric surface, Prairie du

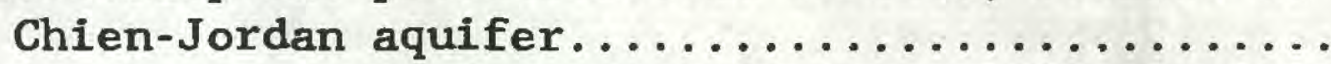

14. Potentiometric surface during winter 1980, Prairie du Chien-Jordan aquifer..................

15. Change in altitude of the potentiometric surface of the Prairie du Chien-Jordan aquifer from pre-

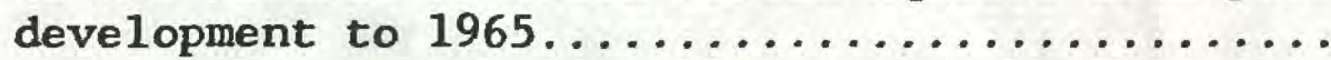

16. Graph showing hydrograph of well open to the Prairie du Chien-Jordan aquifer, Twin Cities Metropolitan

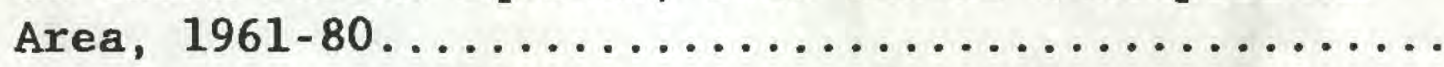


Figures 17-21. Maps showing:

17. Change in altitude of the potentiometric surface of the Prairie du Chien-Jordan aquifer from predevelopment to winter 1980 , Twin

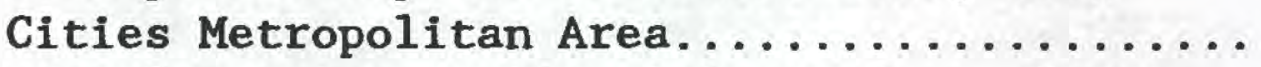

18. Predevelopment potentiometric surface, Mount Simon-Hinckley aquifer..................

19. Potentiometric surface during winter 1980 , Mount Simon-Hinckley aquifer..............

20. Change in altitude of the potentiometric surface of the Mount Simon-Hinckley aquifer from

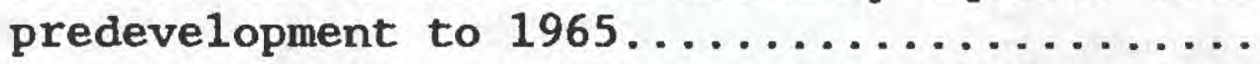

21. Change in altitude of the potentiometric surface of the Mount Simon-Hinckley aquifer from predevelopment to 1980 , Twin Cities Metro-

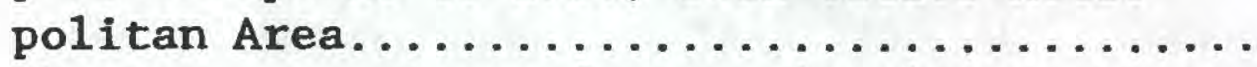

22. Graph showing comparison of water levels, pumpage in the Mount Simon-Hinckley aquifer, and precipitation in the Twin Cities Metropolitan Area.....

23. Schematic hydrogeologic section of a typical river

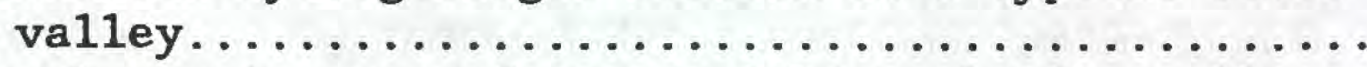

24. Graph showing ground-water withdrawals from all aquifers, $1880-1980 \ldots \ldots \ldots \ldots \ldots \ldots \ldots \ldots \ldots$

25. Finite-difference grid used in model analysis.....

26. Generalized layering scheme for model............

27. Map showing uppermost model layer at each cell.... 28-29. Maps showing:

28. Distribution of bedrock, drift, and driftfilled bedrock valleys in:

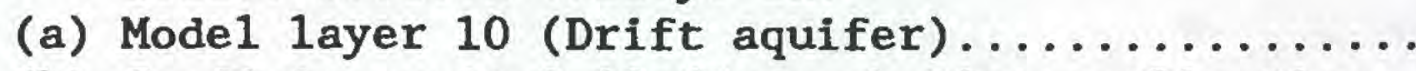

(b) Confining unit 9-10 (Decorah-Platteville-Glenwood confining unit) $\ldots \ldots \ldots \ldots \ldots \ldots \ldots \ldots$

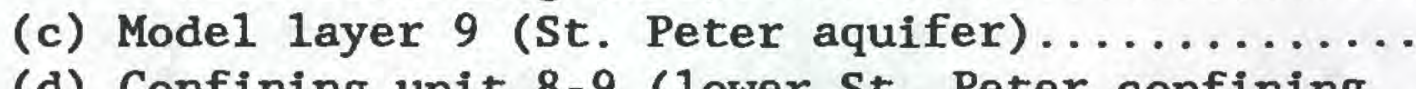

(d) Confining unit 8-9 (lower St. Peter confining

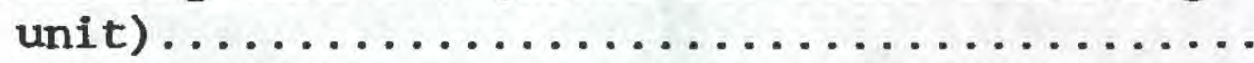

(e) Model layer 8 (Prairie du Chien-Jordan aquifer)

(f) Confining unit 7-8 (St. Lawrence-Franconia con-

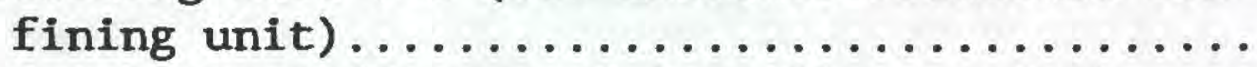

(g) Mode1 layer 7 (Ironton-Galesville aquifer)....

(h) Mode1 layers 2 through 6 and confining units 1-2 through 6-7 (Eau Claire confining unit)..

(i) Mode1 layer 1 (Mount Simon-Hinckley aquifer)... 


\section{ILLUSTRATIONS - - Continued}

\section{Page}

Figure 29. Boundary conditions in:

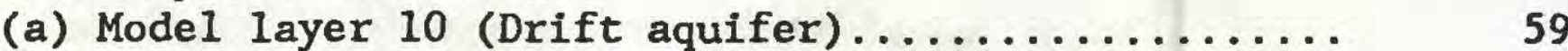

(b) Model layer 9 (St. Peter aquifer)................ 60

(c) Model layer 8 (Prairie du Chien-Jordan aquifer)... 61

(d) Model layer 7 (Ironton-Galesville aquifer)........ 62

(e) Model layer 1 (Mount Simon-Hinckley aquifer)...... 63

30-32. Maps showing zones of:

30. (a) Horizontal hydraulic conductivity in the drift 68

(b) Vertical hydraulic conductivity in the drift.. 69

31. Vertical hydraulic conductivity in the St.

Lawrence-Franconia confining unit...........

32. Vertical hydraulic conductivity in the Eau Claire

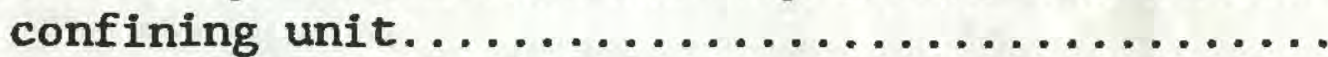

0

2

3

68

69

70

71

33. Maps showing model-calculated potentiometric surface

for the calibration period (1970-79) for:

(a) Model layer 1 (Mount Simon-Hinckley aquifer)...... 72

(b) Model layer 8 (Prairie du Chien-Jordan aquifer)... 73

34-35. Graphs showing:

34. Change in distribution of two-thirds of differences between observed and model-calculated heads (residuals) during model calibration......

35. Changes in standard deviation of the absolute residuals during model calibration............

36. Maps showing distribution of residuals for model calibration for:

(a) Model layer 1 (Mount Simon-Hinckley aquifer)......

(b) Model layer 8 (Prairie du Chien-Jordan aquifer)...

37. Map showing differences between simulated potentiometric surfaces for the calibration period and scenario 1 for:

(a) Model layer 1 (Mount Simon-Hinckley aquifer)......

(b) Model layer 8 (Prairie du Chien-Jordan aquifer)...

38. Sections showing simulated potentiometric surfaces through selected model rows and columns for:

(a) Layer 1 (Mount Simon-Hinckley aquifer)...........

(b) Layer 8 (Prairie du Chien-Jordan aquifer)........

39. Maps showing model-calculated cumulative discharge from aquifers to major streams under steady-state conditions for (a) the 1970's (calibration period),

(b) scenarios 1 and 3, (c) scenario 2 , and

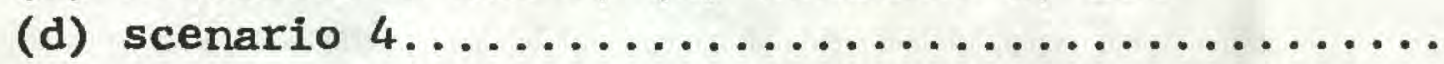


Figures 40-42. Map showing differences between simulated potentiometric surfaces for the calibration period and:

40. Scenario 2 for:

(a) Model layer 1 (Mount-Simon-Hinckley aquifer)... 106

(b) Model layer 8 (Prairie du Chien-Jordan aquifer)..................... 107

41. Scenario 3 for:

(a) Mode1 layer 1 (Mount-Simon-Hinckley aquifer)... 110

(b) Model layer 8 (Prairie du Chien-Jordan

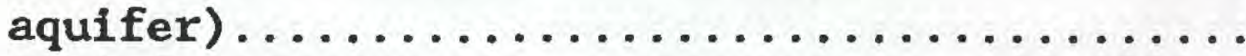

42. Scenario 4 for:

(a) Model layer 1 (Mount-Simon-Hinckley aquifer)... 116

(b) Model layer 8 (Prairie du Chien-Jordan aquifer) 117

43. Graph showing model response to increased simulated pumping rates at cell $(15,30,8) \ldots \ldots \ldots \ldots \ldots \ldots$

A-1. Diagram showing four physical models for the calculation

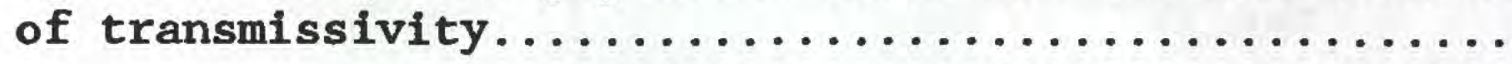

\section{TABLES}

Table 1. Hydrogeologic units and their water-bearing characteristics, Twin Cities aquifer system, Twin Cities

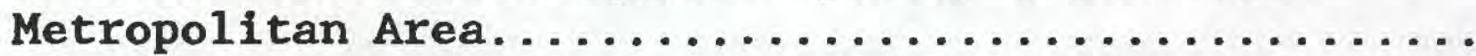

2. Surface-water and ground-water discharges to major rivers, Twin Cities Metropolitan Area.............

3. Initial, final and range of values of horizontal $\left(\mathrm{K}_{\mathrm{H}}\right)$ and vertical $\left(\mathrm{K}_{\mathrm{V}}\right)$ hydraulic conductivities during

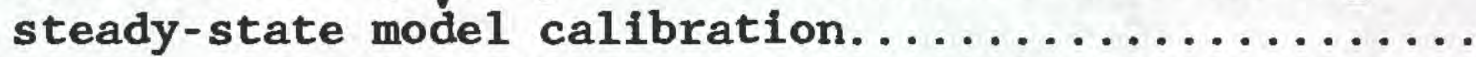

4. Ground-water budget for each model layer for calibra-

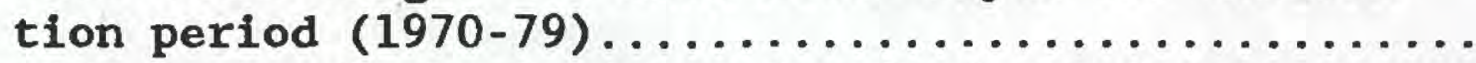

5. Residuals at the beginning and end of steady-state

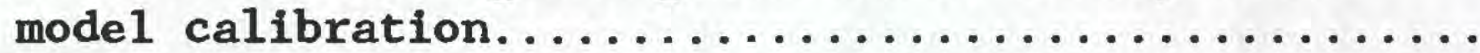

6. Model sensitivity to parameter variation............

7. Projected increases in ground-water withdrawals from the year 1980 for the years 1990 and 2000 for commer-

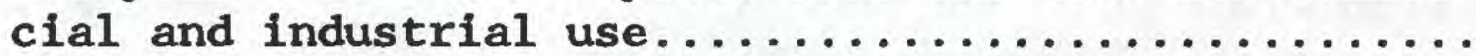

8. Number of additional wells needed to meet population

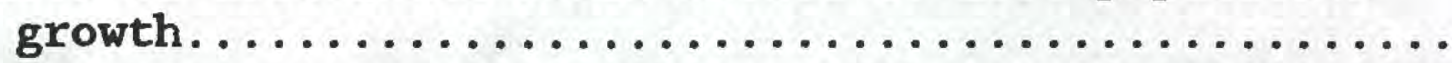

9. Estimated ground-water withdrawals by aquifer and use

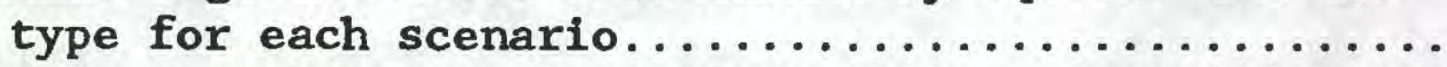

10. Simulated withdrawals for model calibration and development scenarios by model layer................

11. Ground-water budget for each model layer for scenario 1

12. Simulated hydraulic-head differences between the calibration simulation (1970-79) and the four scenarios

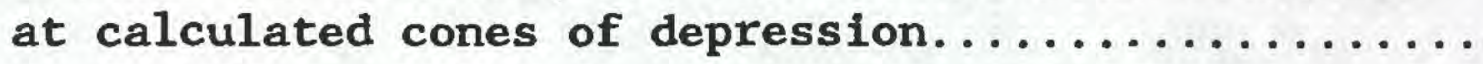


Table 13. Calculated effective recharge, river leakage, and seepage for model calibration and scenarios of future

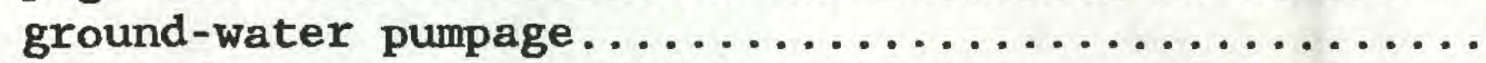

14. Simulated ground-water discharge to streams for river segments along the Crow, Rum, Minnesota, St. Croix,

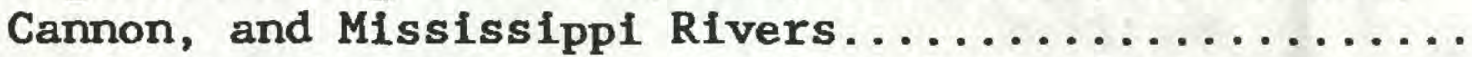

15-17. Ground-water budget for each model layer for:

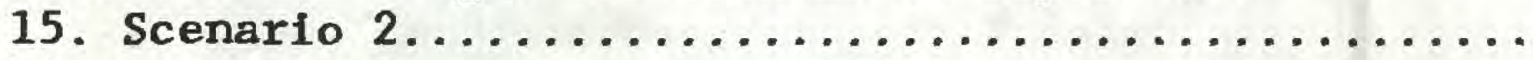

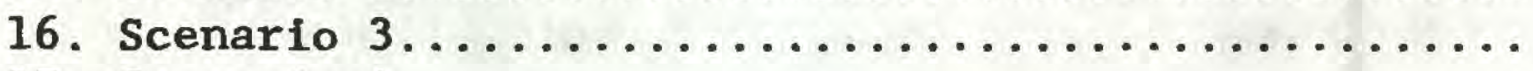

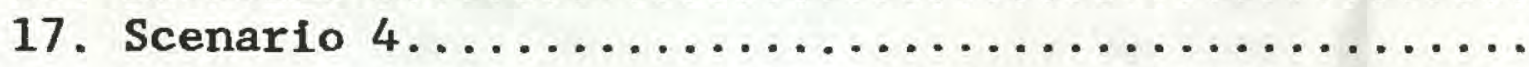

Multiply Inch-Pound Unit

inch (in.)

foot ( $f t$ )

mile (mi)

foot per day (ft/d)

cubic foot per second $\left(\mathrm{ft}^{3} / \mathrm{s}\right)$

gallon per minute (gal/min)

million gallons per day (Mgal/d)

Inch per year (in/yr)
0.06310

By

2.54

0.3048

1.609

0.3048

0.02832

0.04381

2.54
To Obtain Metric Unit

centimeter $(\mathrm{cm})$

meter (m)

kilometer $(\mathrm{km})$

meter per day (m/d)

cubic meter per second $\left(\mathrm{m}^{3} / \mathrm{s}\right)$

liter per second (L/s)

cubic meter per second $\left(\mathrm{m}^{3} / \mathrm{s}\right)$

centimeter per year $(\mathrm{cm} / \mathrm{yr})$

Sea level: In this report "sea level" refers to the National Geodetic Vertical Datum of 1929 (NGVD of 1929)--a geodetic datum derived from a general adjustment of the firstaorder level nets of both the United states and Canada, formerly called "Sea Level Datum of 1929." 


\title{
EFFECTS OF PRESENT AND PROJECTED GROUND-WATER WITHDRAWALS ON THE TWIN CITIES AQUIFER SYSTEM, MINNESOTA
}

\begin{abstract}
The Twin Cities aquifer system in Minnesota contains 5 aquifers and 4 confining units composed of 14 stratigraphic units. Bedrock aquifers consist of friable sandstones and highly fractured carbonate rocks; aquifers in the glacial drift consist of outwash and alluvium. From 1880 to 1980 , groundwater withdrawals had caused long-term declines of water levels of as much as 90 feet in the Prairie du Chien-Jordan aquifer and 240 feet in the deeper Mount Simon-Hinckley aquifer--the two major sources of ground-water supplies in the area. A steady-state model of ground-water flow was used successfully to simulate the potentiometric surfaces of the aquifers during the 1970's, assuming a withdrawal rate of about 190 million gallons per day from the entire system.
\end{abstract}

Projected changes in population and industrial development suggest that future ground-water withdrawals may increase from those for the $1970^{\circ} \mathrm{s}$. Steady-state model results indicate that the potentiometric surface of the Mount Simon-Hinckley aquifer would be lowered as much as 400 feet if pumpage from that aquifer were increased by 125 percent above 1980 ground-water withdrawal rates of about 200 million gallons per day. The potentiometric surface of the Prairie du Chien-Jordan aquifer also would be lowered as much as 400 feet if pumpage from that aquifer were increased by 200 percent above 1980 ground-water withdrawals of 160 million gallons per day. Given the projected distribution of future ground-water development, and the limitations inherent in simulating ground-water flow, the model results indicate that an approximate limit of ground-water availability in the Twin Cities Metropolitan Area, Minnesota, is from about 500 to 800 million gallons per day.

\section{INTRODUCTION}

The Twin Cities Metropolitan Area (fig. 1) depends heavily on ground water. This dependence began in the $1880^{\prime} \mathrm{s}$, when large quantities of water were needed for fire protection, public supply, and commercial and industrial use. By the late 1970's about $200 \mathrm{Mgal} / \mathrm{d}$ (million gallons per day) of water were used. During the period 1976-79, ground water supplied 62 percent of a11 water used, excluding instream use by electrical powerplants. of all the water used, ground water supplied 29 percent for municipal use, 27 percent for self-supplied industrial and commercial use, and 6 percent for irrigation and golf-course watering (Horn, 1983). The remaining water used (38 percent) came from the Mississippi River, which serves as the primary municipal water supply for Minneapolis, St. Paul, and the cities they supply.

Future changes in ground-water use within the study area depend on continued changes in land use, population, and economic development (Oberts, 1984). The present distribution of ground-water use is determined by the distribution of rural, mixed rural and suburban, suburban, and urban areas and their different water-use patterns. The conversion of rural and undeveloped suburban areas to developed suburban and urban locales in the future will 




Figure 1.--Location of study area 
increase ground-water use. In addition, development will reduce open areas through which "precipitation can infiltrate to and recharge the ground-water system.

This report describes the third phase of a three-phase, multiyear study, conducted by the U.S. Geological Survey in cooperation with the Minnesota Department of Natural Resources and the Metropolitan Council of the Twin Cities, to (1) develop a detailed understanding of the hydrogeologic system in the Twin Cities Metropolitan Area, (2) evaluate the hydrologic effects of continued development of ground-water supplies, and (3) provide sound technical information and a predictive tool for wise continued development of ground-water supplies. In the first phase, Guswa and others (1982) developed a preliminary ground-water-flow model. Horn $(1983,1984)$ and Schoenberg (1984) collected and reported additional water-use and potentiometric data, respectively, in the second phase.

\section{Purpose and Scope}

The purpose of this report is to (1) consolidate geologic and hydrologic information on the aquifer system in the study area, and (2) describe the development and application of a model to simulate ground-water flow in the aquifer system for the period 1970-79.

The model used to simulate ground-water flow is used to test the possible effects of projected ground-water withdrawals of (1) $370 \mathrm{Mgal} / \mathrm{d}$; (2) 510 Mgal/d, with major increases in pumpage from the Prairie du Chien-Jordan aquifer and aquifers in the drift; (3) $370 \mathrm{Mgal} / \mathrm{d}$, with major increases in pumpage from the Prairie du Chien-Jordan and Mount Simon-Hinckley aquifers; and (4) $665 \mathrm{Mgal} / \mathrm{d}$ (representing drought conditions), with major increases in pumpage from the Pralrie du Chien-Jordan aquifer and aquifers in the drift. The consequences of various water-use scenarios, which illustrate possible responses of the hydrologic system to successively increasing demands on the ground-water resource, are discussed.

\section{Previous Studies}

The Twin Cities Metropolitan Area has been described in terms of regional and local hydrology. In an early report, Hall and others (1911) evaluated the ground-water resources of the area while discussing all of southern Minnesota. Thiel (1944) described the Twin Cities Metropolitan Area in the context of southern Minnesota. Prior and others (1953), Liesch (1961), Minnesota Conservation Department, Division of Waters (1961), and Norvitch and others (1974) described the hydrology of the study area only. Norvitch and others (1974) give a significant summary of the regional hydrology. The reader is referred to that report for additional background information.

\footnotetext{
"Words listed in the slossary are shown in bold italicized print where first used.
} 
Many reports address specific aspects of the hydrology of the Twin Cities Metropolitan Area. Lindholm and others (1974) discussed the hydrogeology of the lower St. Croix River valley in Washington County. Larsen-Higdem and others (1975) reported on the configuration of the vater table in the sevencounty metropolitan area and estimated recharge from the surface to the Prairie du Chien-Jordan aquifer. Helgesen and Lindholm (1977) described the hydrology of outwash in the vicinity of Anoka County (Anoka sandplain), and Winter and Pfannkuch (1976) described the relationship of that sandplain to a drift-filled bedrock valley. Winter and Pfannkuch (1976) also discussed the effects of a drift-filled bedrock valley on the hydrologic system. Reeder and others (1976) investigated the effects of fractures in the Prairie du ChienJordan aquifer on artificial recharge through a well. Madsen and Norvitch (1979) described the constraints placed on tunneling through the St. Peter aquifer related to the hydraulic properties of that unit. More recently, Ehrlich and others (1982), Hult and Schoenberg (1983), and Stark and Hult (1985) described ground-water contamination by coal-tar derivatives in St. Louis Park, Minnesota. Woodward (1986) described regional hydraulic properties; Delin and Woodward (1985) described regional potentiometric surfaces in bedrock aquifers; and Woodward (1985) described historical trends in the installation of municipal wells and utilization of aquifers. Miller (1983, 1984, 1985), Blair and Deutsch (1983), and Hoyer and Walton (1983) described the results of injecting, storing, and retrieving hot water in and from the Ironton-Galesville aquifer and part of the St. Lawrence-Franconia confining unit.

Several reports describe the hydrogeological framework of the Twin Cities aquifer system. Theil (1956), Craddock and others (1963), Sims and Zeitz (1967), and Mooney and others (1970) discuss development of the Twin Cities basin during the Proterozoic Eon as a dropped-block structure along the midcontinental gravity high. Austin (1972) considered the coeval development of the basin and the Hollandale Embayment during the Cambrian Period. Austin (1972), Morey (1972), and Mossler (1972) discuss evolution of the Twin Cities basin through the Ordovician Period and the materials deposited therein.

\section{Acknowledgments}

Crucial data for simulation of the various development scenarios were provided by Gary Oberts, Metropolitan Council of the Twin Cities, and Gina Miller, Minnesota Department of Natural Resources, and are gratefully acknowledged. In addition, they, along with Marcel Jouseau, Metropolitan Council of the Twin Cities, and Sarah Tufford, Minnesota Department of Natural Resources, helped formulate the scenarios so that the model simulations would provide meaningful results for ground-water-resource planning and management.

\section{GENERAL DESCRIPTION OF AQUIFER SYSTEM}

The framework of the Twin Cities aquifer system can be described under three major topics: (1) hydrogeologic setting and hydraulic properties; (2) drift-filled, buried-bedrock valleys; and (3) present-day river valleys. Geology and stratigraphy determine the areal extent, thickness, altitude of the top, and 1ithologic character of individual units in the Twin Cities aquifer system. Hydraulic properties are based on the water-transmitting 
characteristics of the five aquifers and four confining units. The movement of water between major streams and the ground-water system is affected by the hydraulic connection between the streambed, the alluvium, and the bedrock aquifers.

\section{Hydrogeologic Setting and Hydraulic Properties}

Bedrock units of the aquifer system consist of about $1,000 \mathrm{ft}$ of sedimentary rocks that fill the spoon-shaped Twin Cities basin (Sims and Zietz, 1967). This material was deposited from Late Proterozoic to Early Ordovician time. Initial rates of deposition matched rates of subsidence throughout the basin. During the later phases of deposition, thicker deposits accumulated in the center of the basin than around the periphery (Austin, 1972; Morey, 1972; Mossler, 1972). Subsidence faults cut some of the lower units (Jirsa and others, 1986). As much as $600 \mathrm{ft}$ of unconsolidated deposits of Pleistocene age drape the bedrock (Jirsa and others, 1986).

The 9 hydrogeologic units (fig. 2), 5 aquifers and 4 confining units, in the aquifer system comprise 14 geologic formations in the Twin Cities basin (table 1). The major physical and hydraulic characteristics of the hydrogeologic units in the study area are described in table 1 . Characteristics of hydrogeologic units that affect ground-water flow in the study area are areal extent and continuity, geometry, hydraulic boundaries, and grain-size variations and consequent hydraulic conductivity (table 1, figs. 3-10).

\section{Drift-filled Bedrock Valleys}

Valleys developed on the preglacial bedrock surface have been filled with drift consisting mainly of glacial outwash and till (fig. 2). In comparison to the present-day surface, which generally has less than $150 \mathrm{ft}$ of relief and a few deeply incised streams, the preglacial surface had an extensive and well-developed drainage system (fig. 11).

Understanding the relation of the drift-filled bedrock valleys to the aquifer system depends on understanding both the morphology of the preglacial erosional surface and the type of glacial materials that cover that surface. The different properties of the drift in the four zones (fig. 12) affect the local movement of ground water in drift-filled bedrock valleys. Variations in depositional sequences control the vertical and horizontal hydraulic properties of deposits in the valleys. The most significant aspect of drift-filled valleys is the manner in which they physically disrupt the continuity of bedrock aquifers and confining units (fig. 2). Because the vertical hydraulic conductivity of drift is about 10 to 100 times higher than that of the bedrock confining units, valleys that breach the bedrock confining units short-circuit vertical flow through the bedrock by providing a more rapid flow path for ground water.

The preglacial surface is implied from data collected in the process of drilling water wells and test borings. These data are collected at discrete points. The smooth surface which is interpreted as passing through these points is based on comparisons with typical nonglacial or heavily eroded glacial surfaces such as are found in the "driftless zone" in southeastern Minnesota (Jirsa, M. A., Minnesota Geological Survey, oral commun., 1980). 
The preglacial surface had many geomorphic features presently found in the study area. For example, the St. Croix River valley along eastern Washington County is a modern analog of the ancestral Mississippi River Valley. Steep-sided valley walls, with drops of 60 to $100 \mathrm{ft}$, similar to those found along the Mississippi River from Nininger to Minneapolis, bordered the ancestral Mississippi River and its tributaries as they cut their way across what is now Dakota and Scott Counties. From highest to lowest, there was a drop of about 500 to $600 \mathrm{ft}$ over a distance of 5 to $10 \mathrm{mi}$ (miles). Most of the change in elevation occurs where a dolomitic layer overlaid a friable, poorly cemented sandstone; for example, where the Platteville Formation and Prairie du Chien Group of Ordovician age overlie the St. Peter Sandstone of Ordovician age and the Jordan Sandstone of Cambrian age, respectively. Between the areas of sharp elevation change, the landscape was gently rolling. On average, the steepest slope from the top of the highlands to the bottom of the valleys was a two-percent grade.

The buried preglacial surface has a distorted rectangular pattern of valleys in an arc swinging from northeastern Dakota County through Anoka and Hennepin Counties, ending in Carver County. This pattern is known as trellis drainage. The valleys roughly parallel the edges of the Twin Cities Basin.

\section{River Valleys}

Three major and three minor rivers flow through the study area; these are the Minnesota, Mississippi, and St. Croix Rivers and the Cannon, Crow, and Rum Rivers, respectively (fig. 1). The major rivers have cut channels into the bedrock that are filled with as much as $200 \mathrm{ft}$ of drift and alluvium (Jirsa, M. A., Minnesota Geological Survey, written commun., 1981) (fig. 2). The Ironton-Galesville aquifer is the lowermost aquifer incised by river valleys in the study area (fig. 8). Floodplains of the major rivers are narrower along bedrock-walled channels, but may be a mile wide in the pre-Wisconsin ancestral Mississippi River drainage way.

\section{CONCEPTUALIZED GROUND-WATER-FLOW SYSTEM}

Ground water moves from areas of recharge to areas of discharge, and the distribution of hydraulic head controls the direction of ground-water flow through the system. Hydraulic stresses, which include natural recharge (precipitation), natural discharge (seepage to rivers), and manmade discharge (pumpage) drive the flow system. 

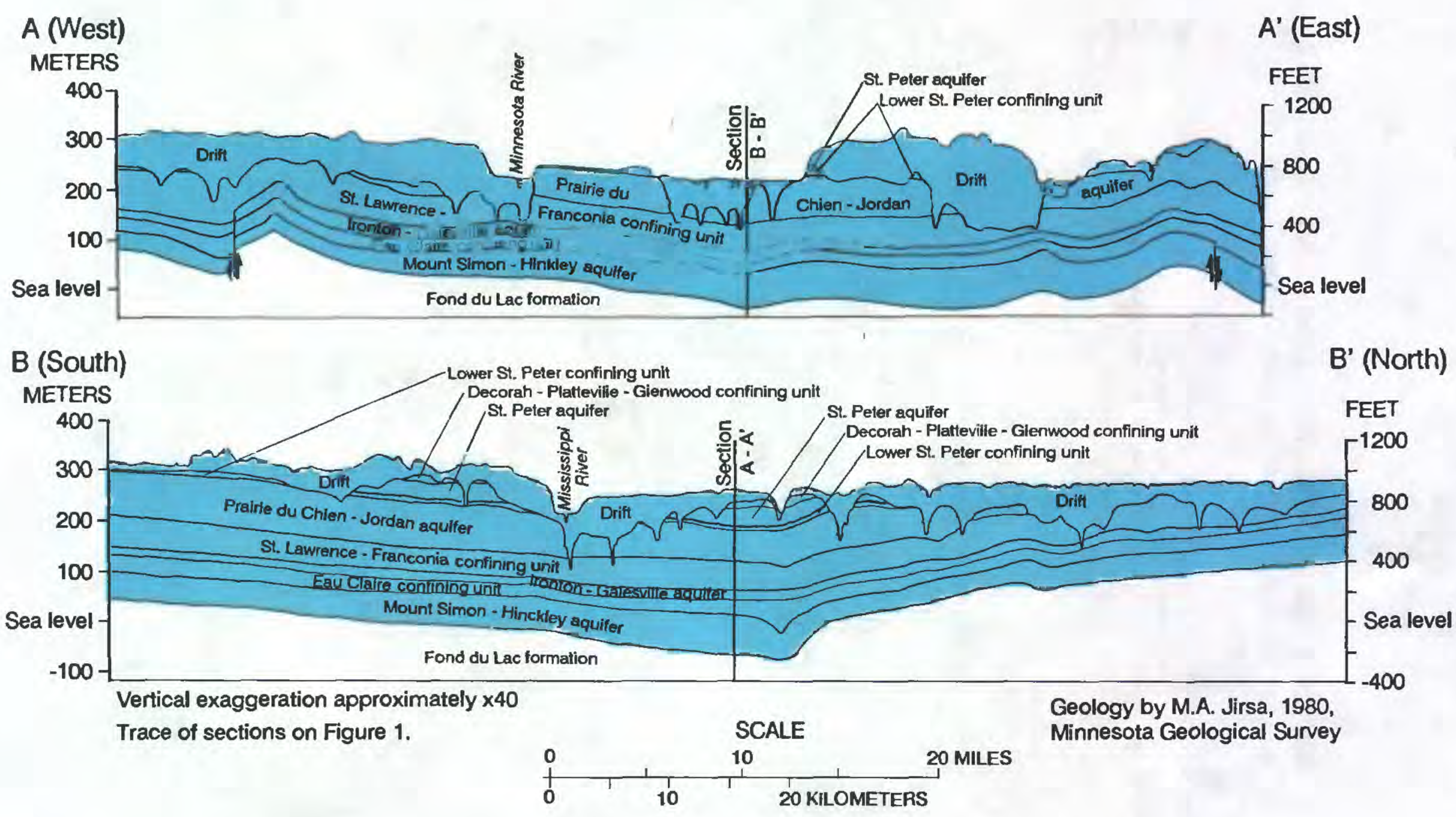

\section{EXPLANATION}

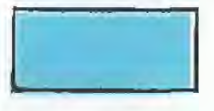

Twin Cities aquifer system

$\|$ Fault-arrows show direction of relative motion

Figure 2.--Hydrogeologic sections through study area. 


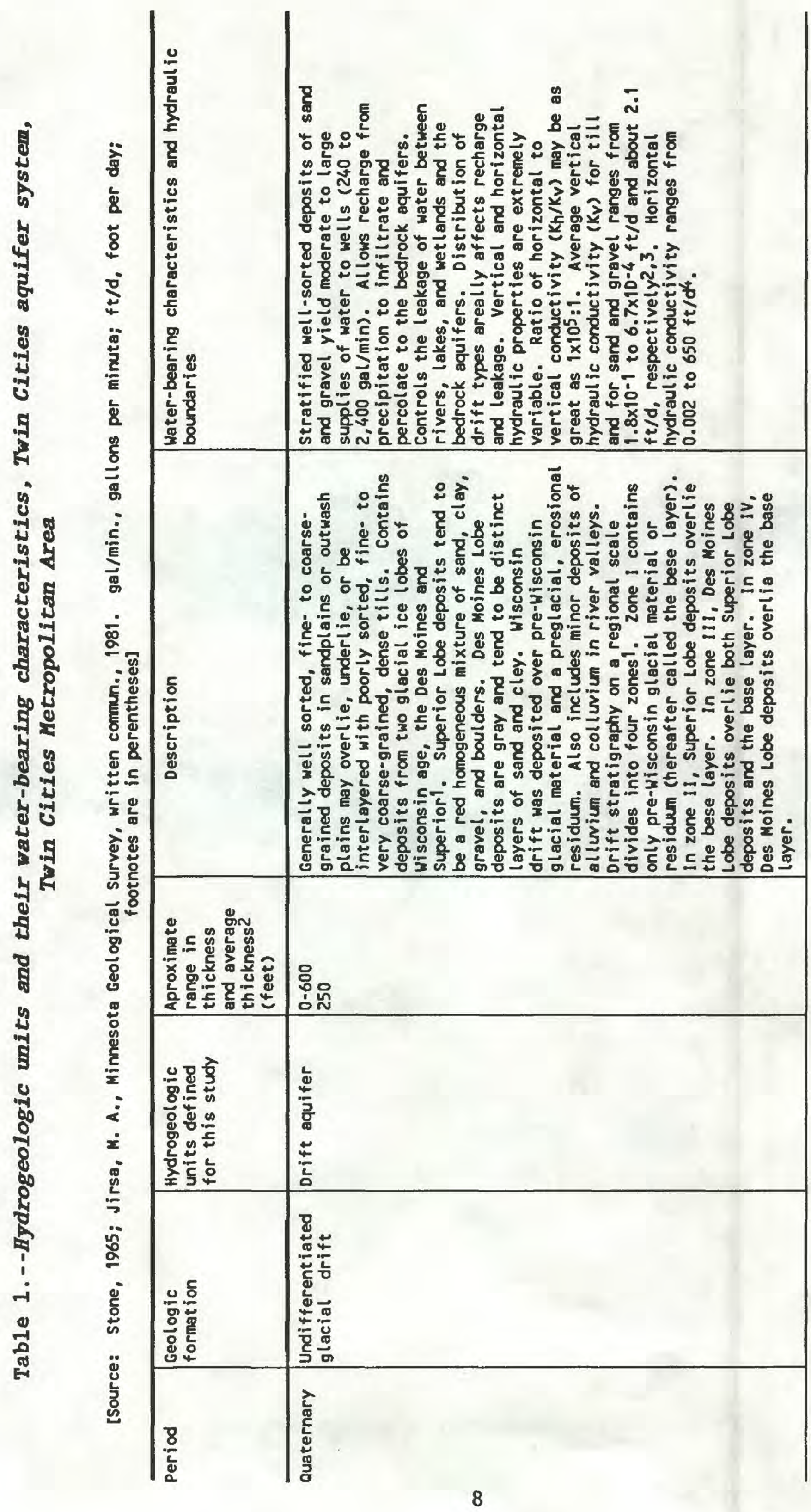




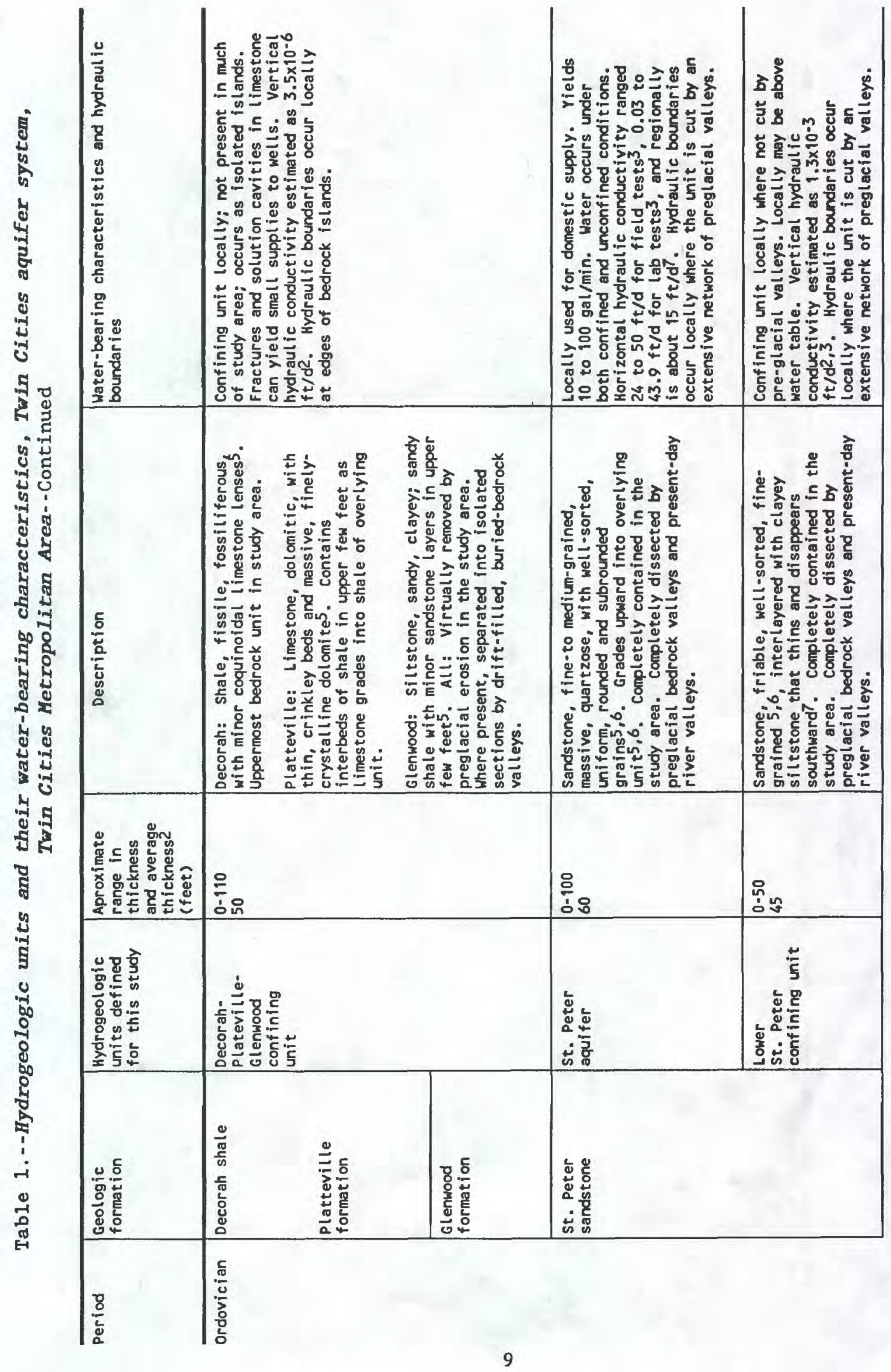




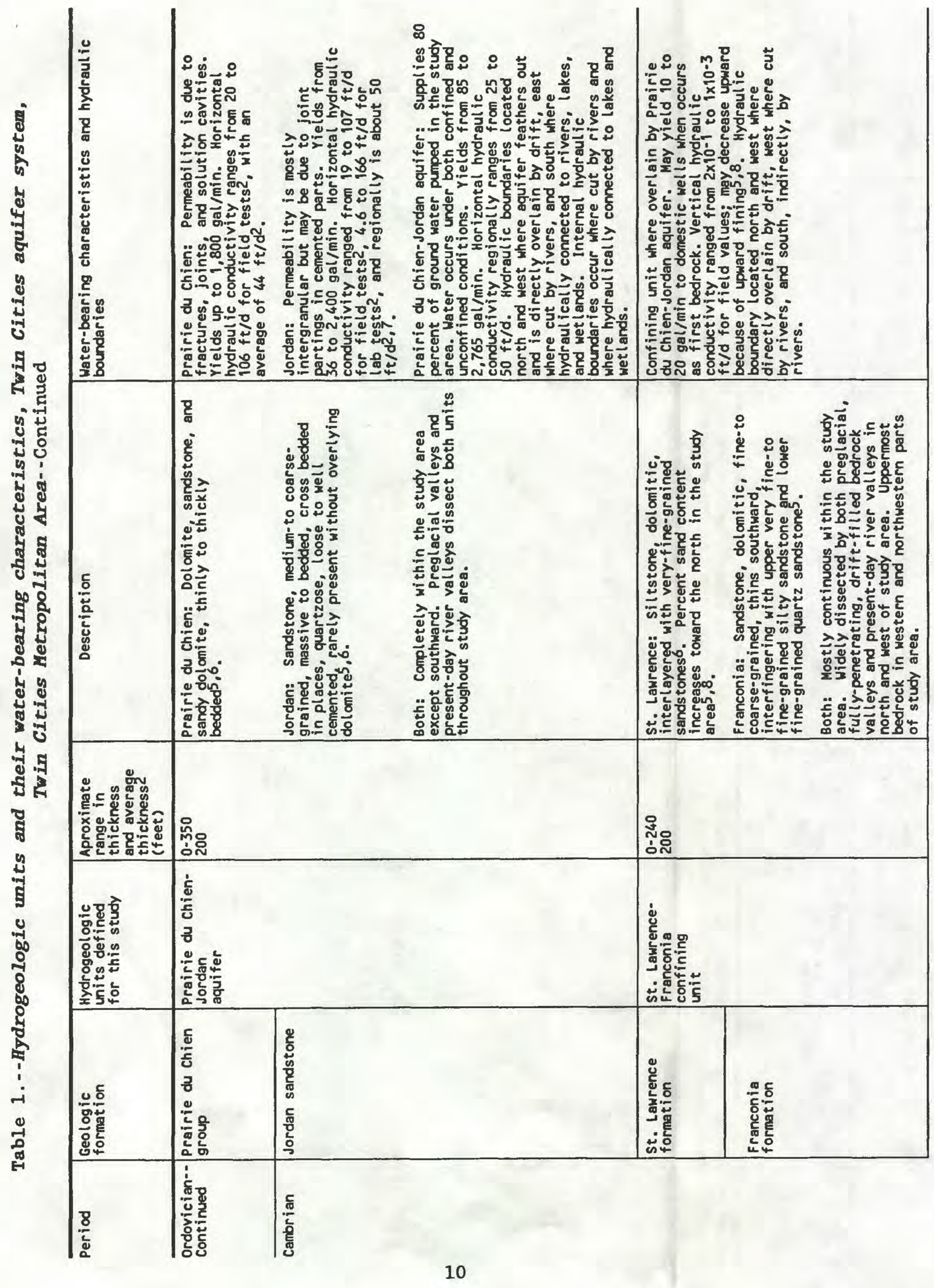




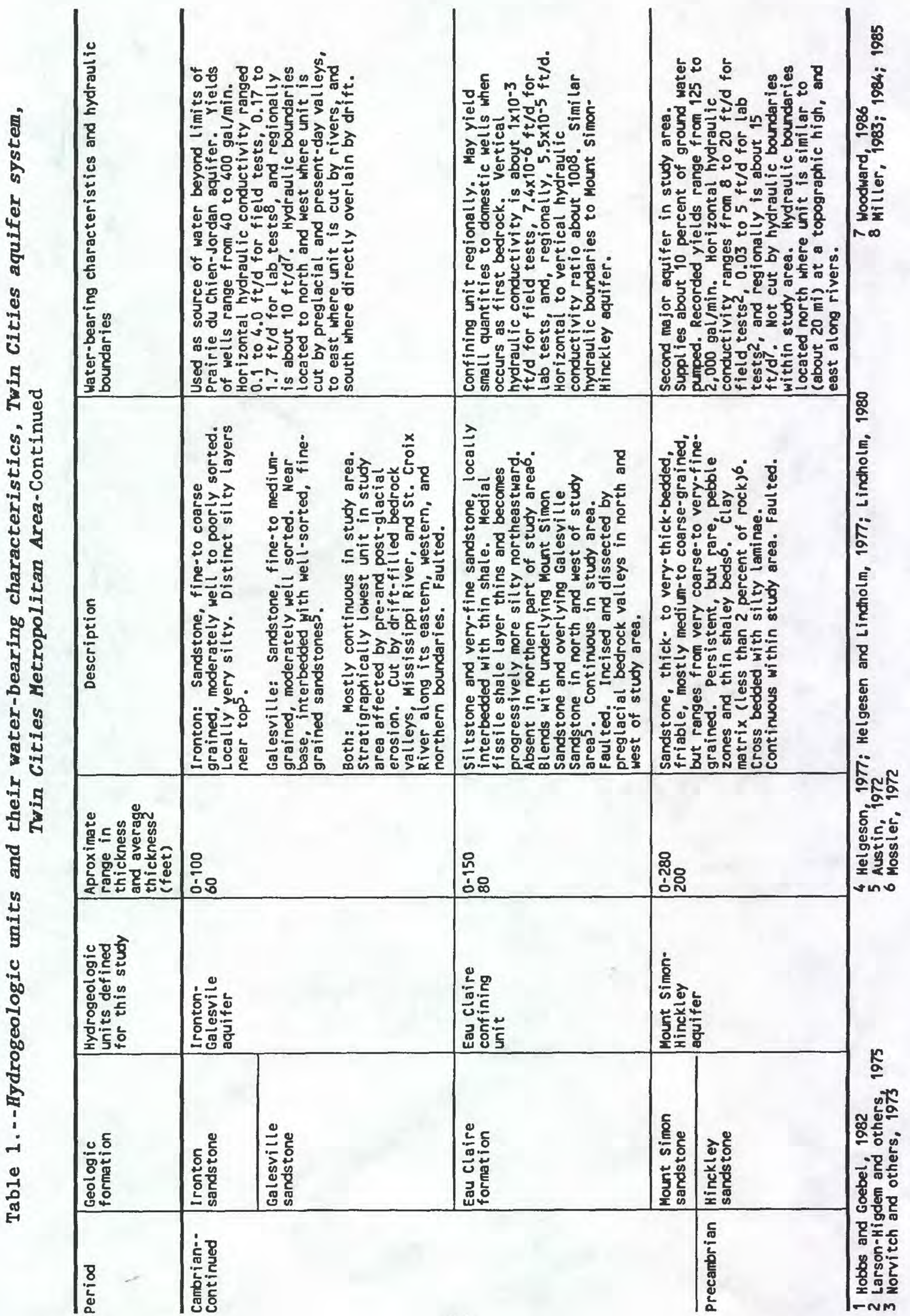




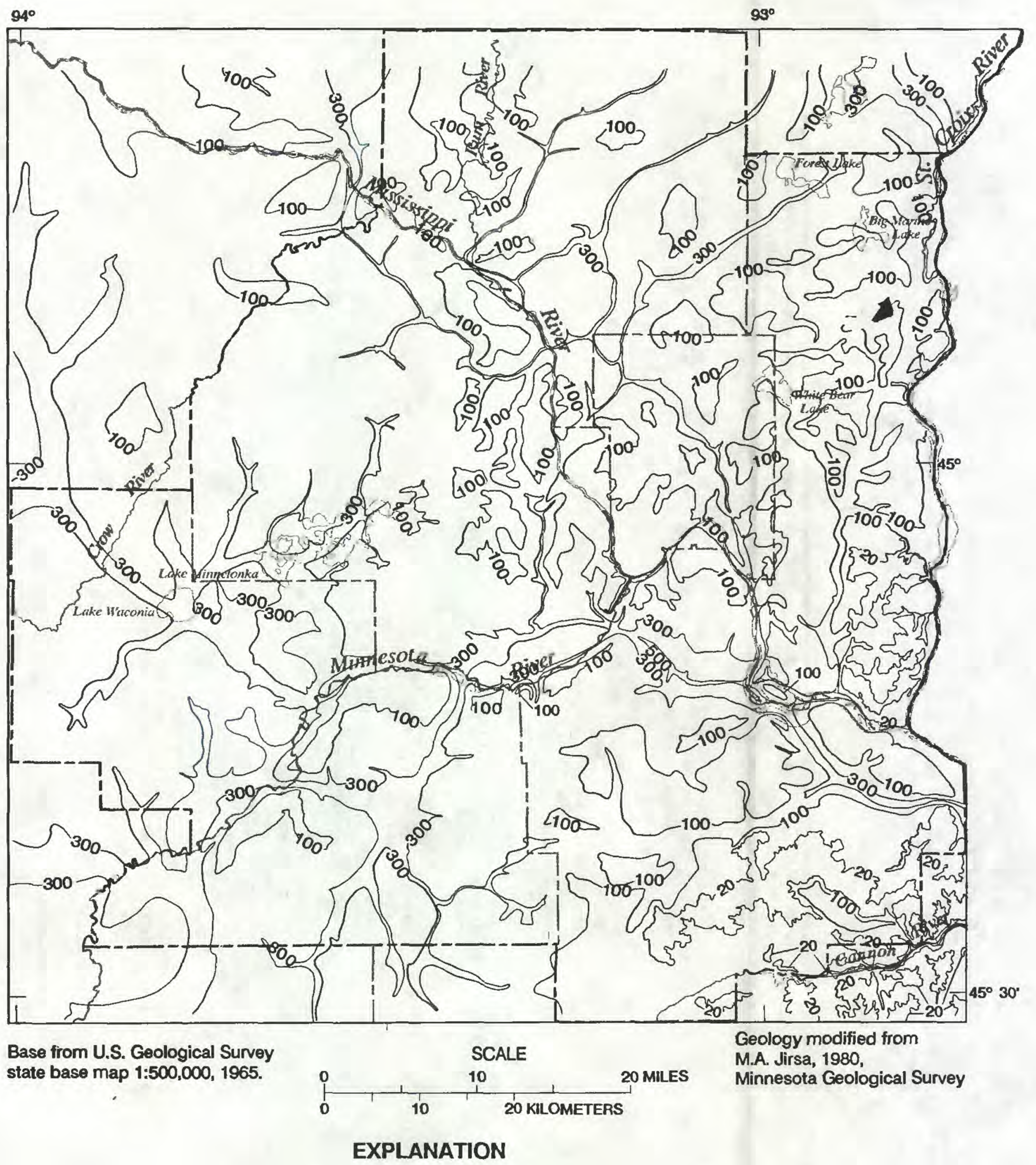

- 300 - Line of equal thickness of glacial drift. Interval, in feet, is variable.

Boundary of Twin Cities Metropolitan Area

Figure 3.--Thickness of the glacial drift. 


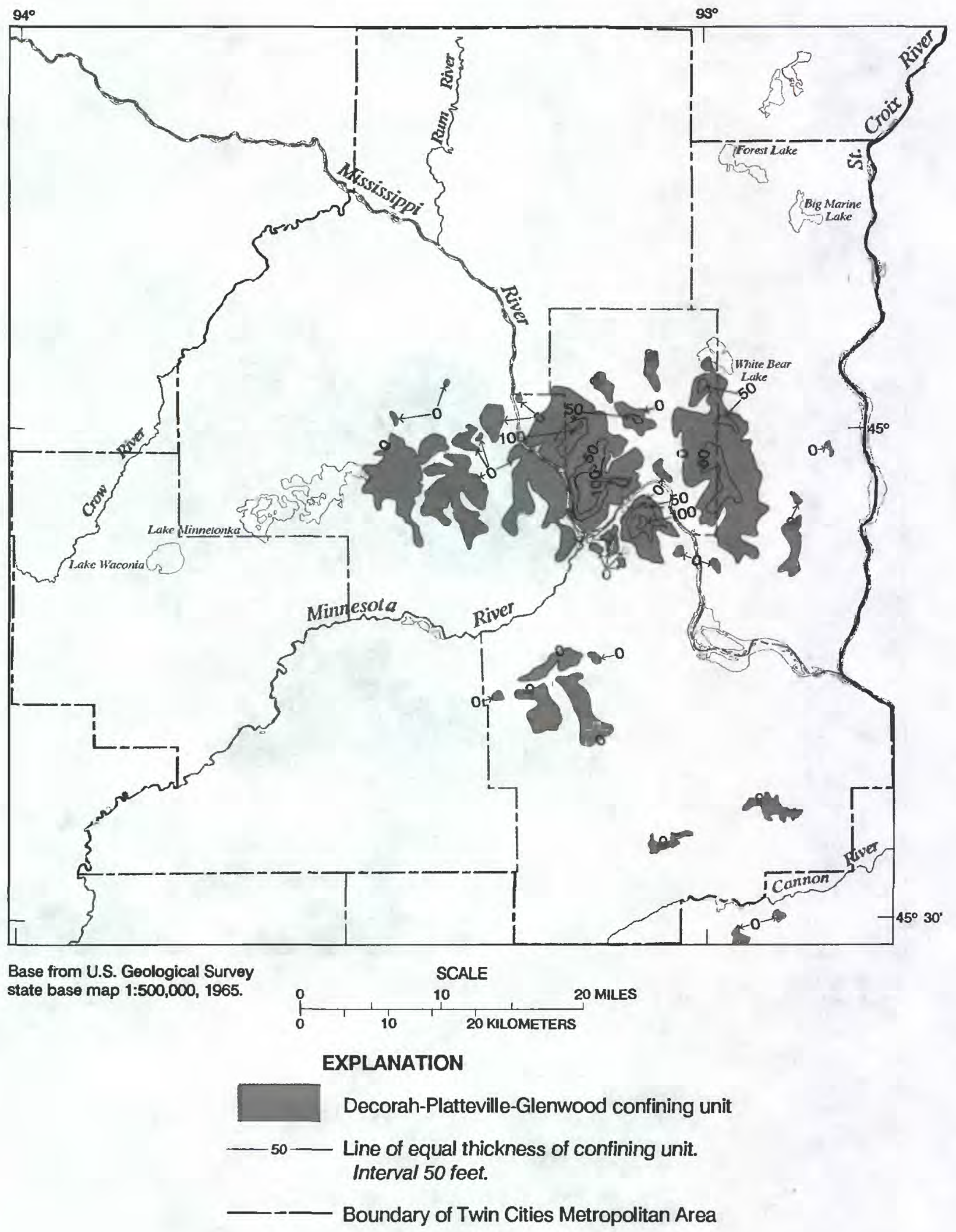

Figure 4.--Thickness of the Decorah-Platteville-Glenwood confining unit. 

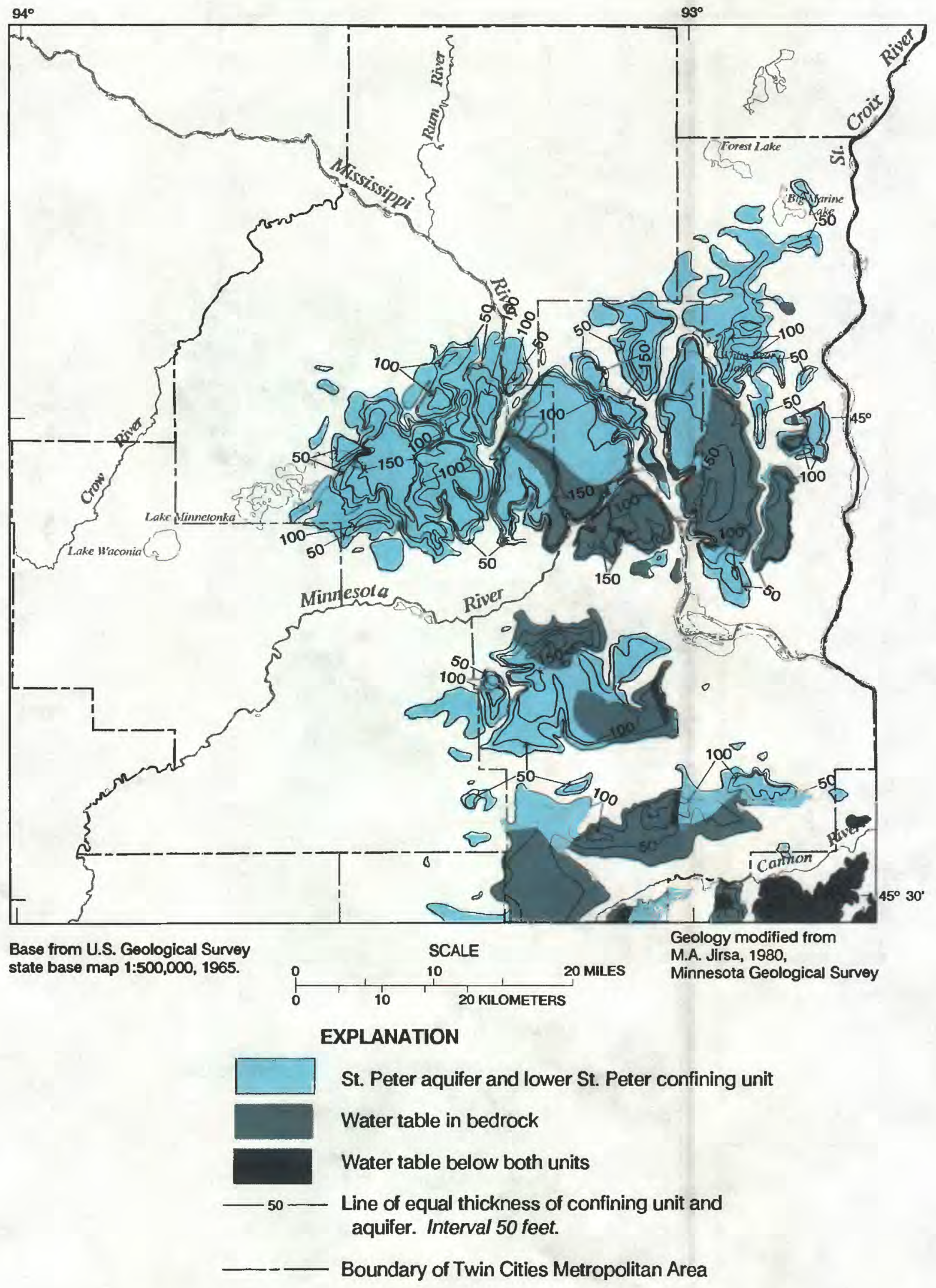

Figure 5.-Composite thickness of the St. Peter aquifer and lower St. Peter confining unit. 


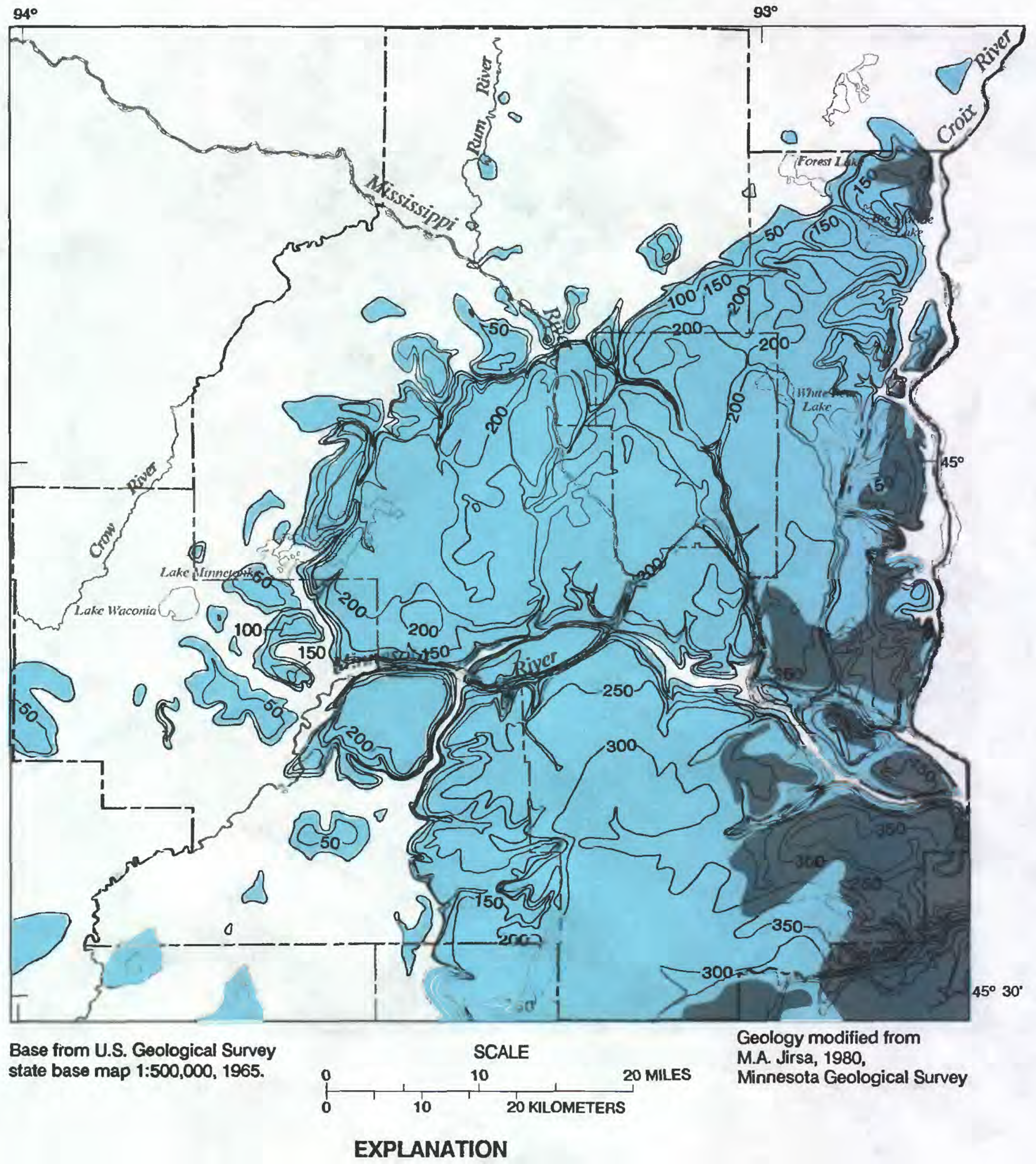

Prairie du Chien-Jordan aquifer

Water table in bedrock

Line of equal thickness of aquifer. Interval 50 feet.

Boundary of Twin Cities Metropolitan Area

Figure 6.--Thickness of the Prairie du Chien-Jordan aquifer. 


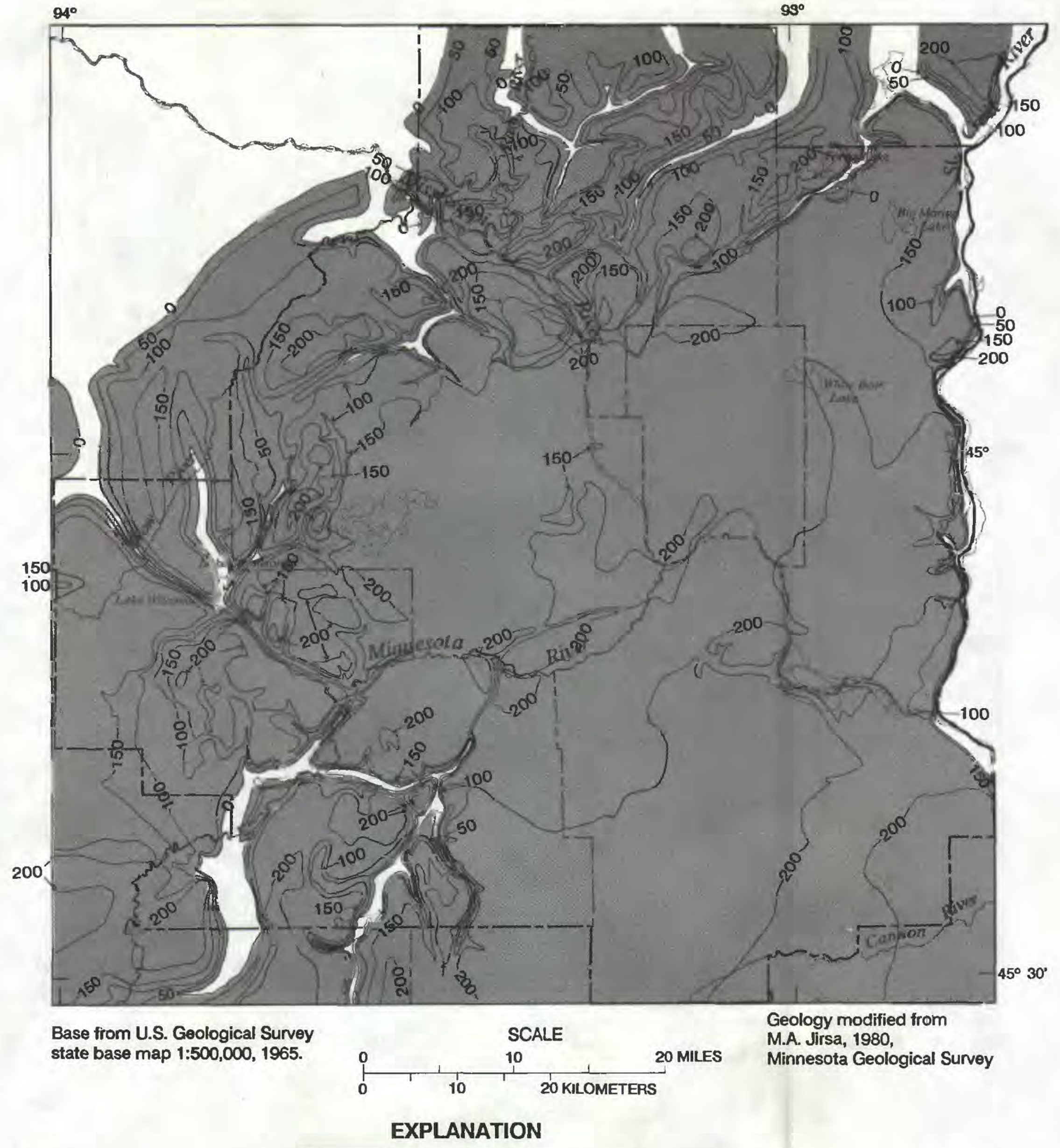

St. Lawrence-Franconia confining unit

- 50 - Line of equal thickness of confining unit. Interval, in feet, is variable.

Boundary of Twin Cities Metropolitan Area

Figure 7.--Thickness of the St. Lawrence-Franconia confining unit. 


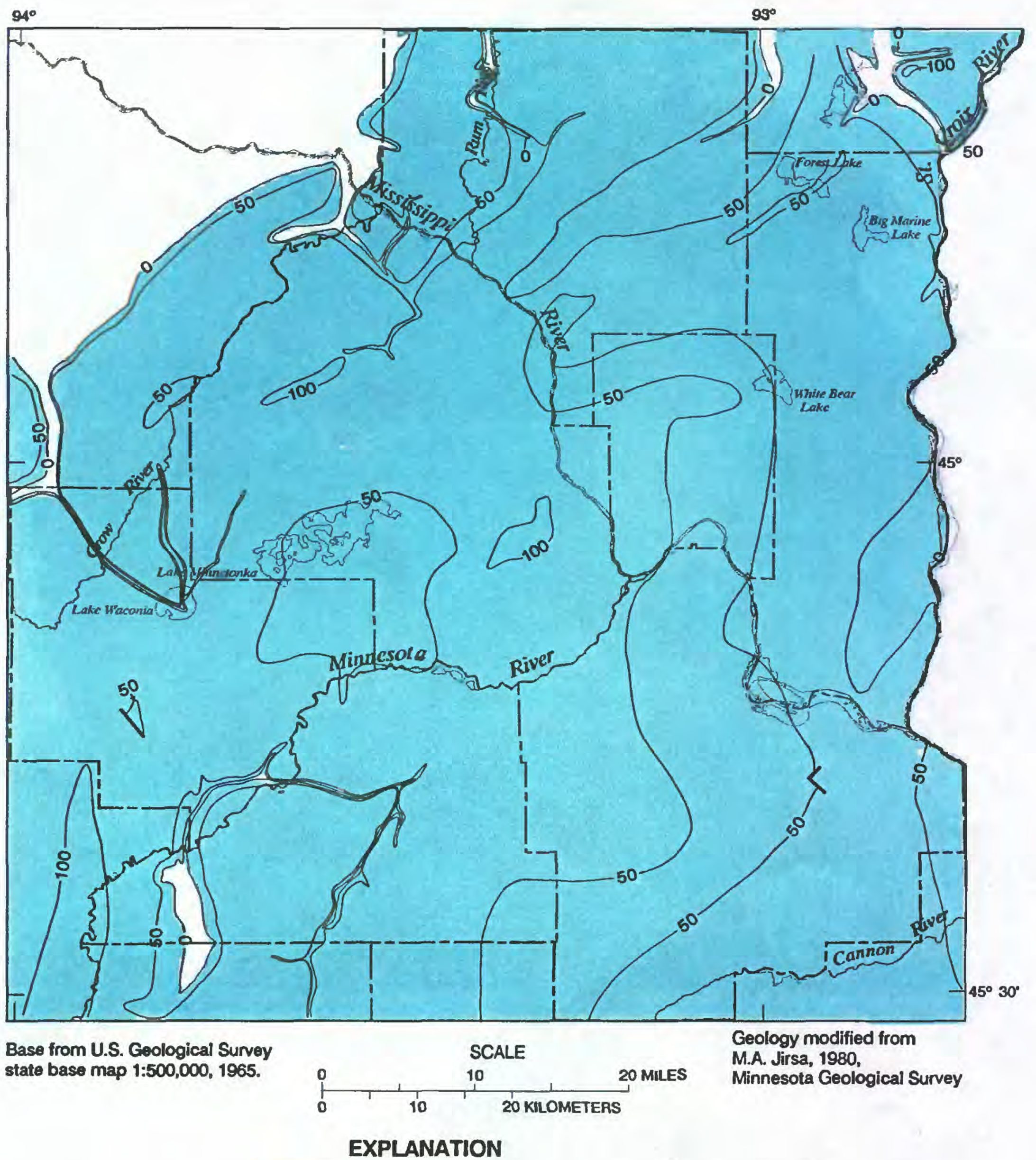

Ironton-Galesville aquifer

Line of equal thickness of aquifer. Interval 50 feet.

Fault trace

Boundary of Twin Cities Metropolitan Area

Figure 8.-Thickness of the Ironton-Galesville aquifer. 

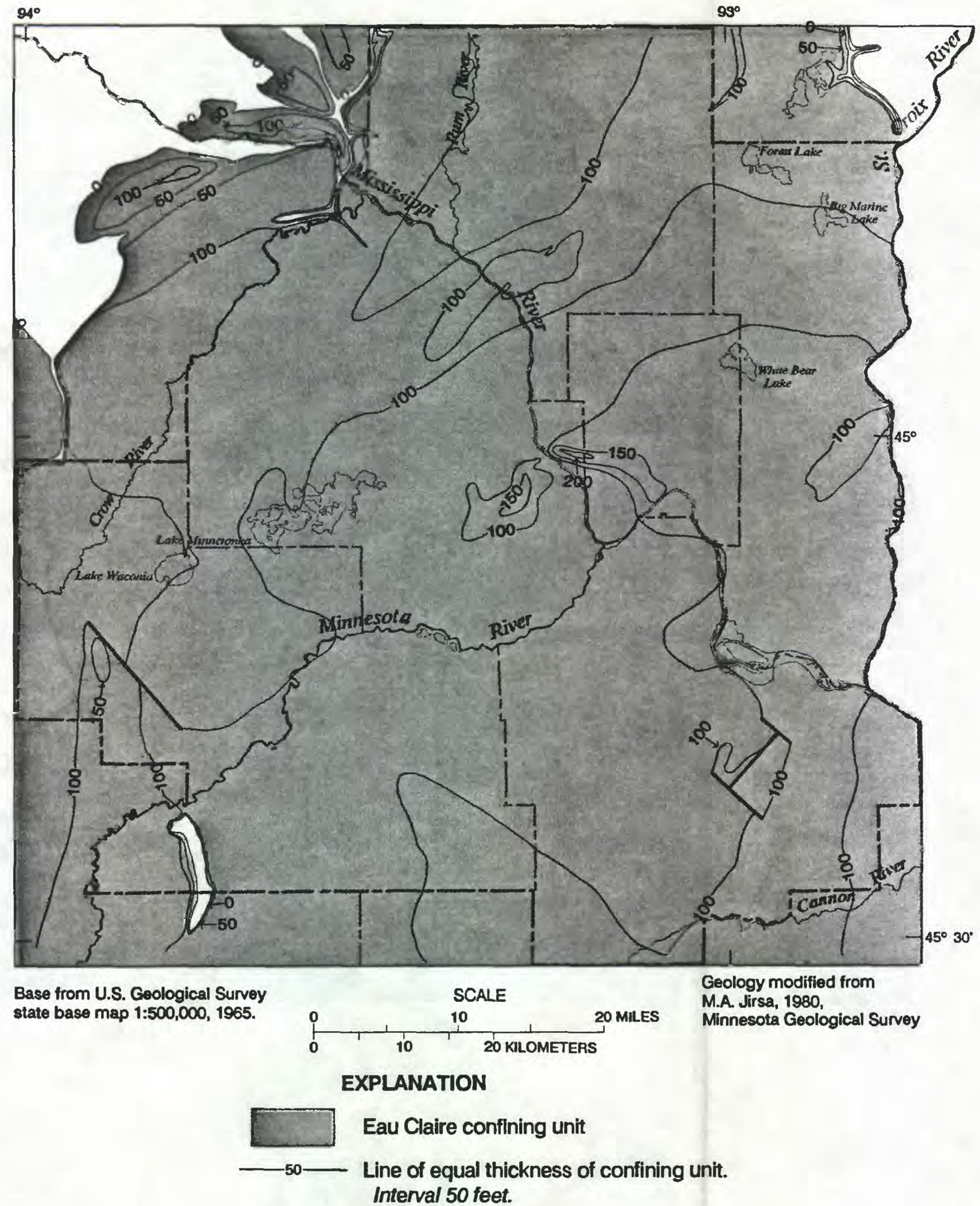
Interval 50 feet.

Fault trace

Boundary of Twin Cities Metropolitan Area

Figure 9.-Thickness of the Eau Claire confining unit. 


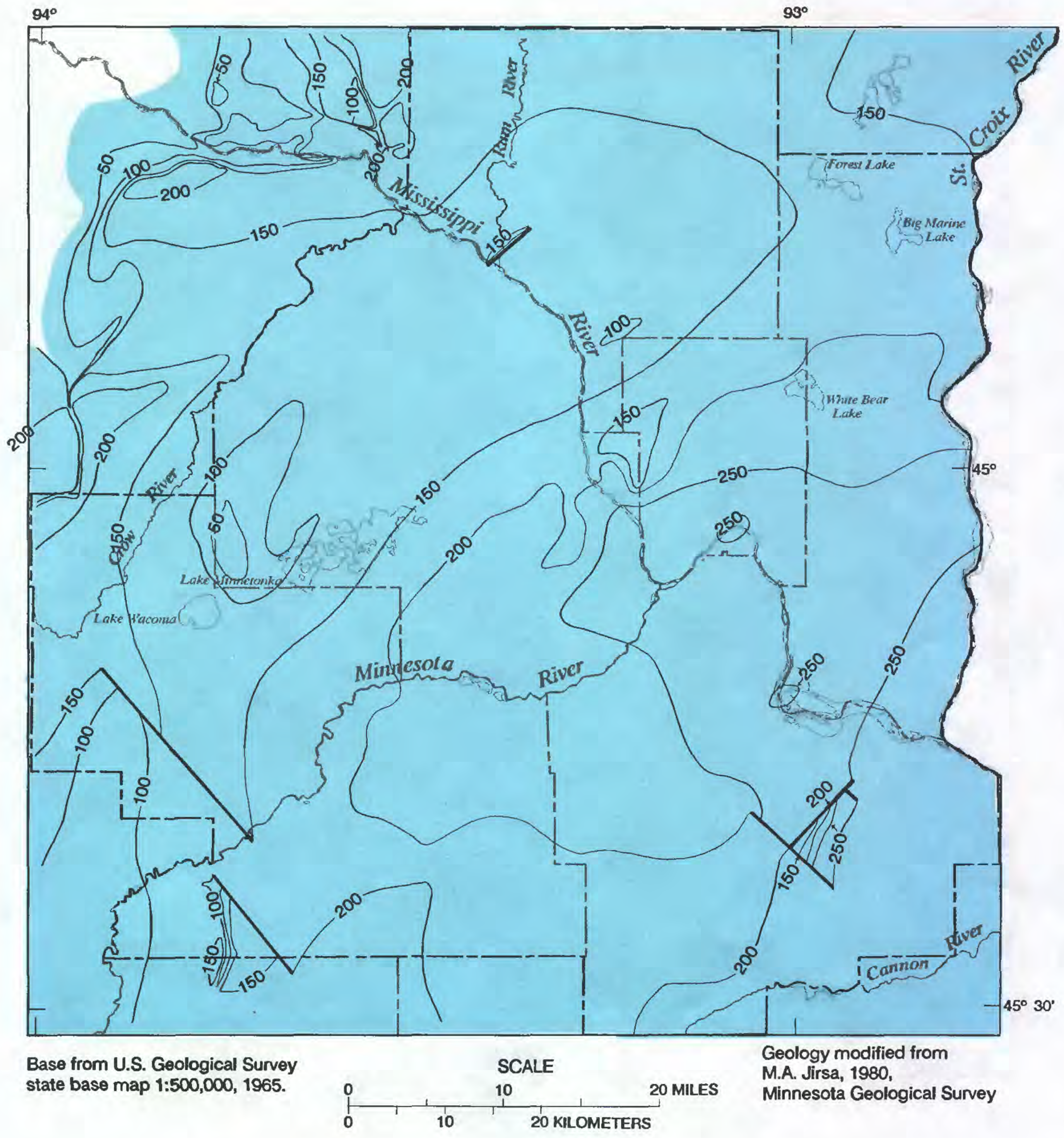

EXPLANATION

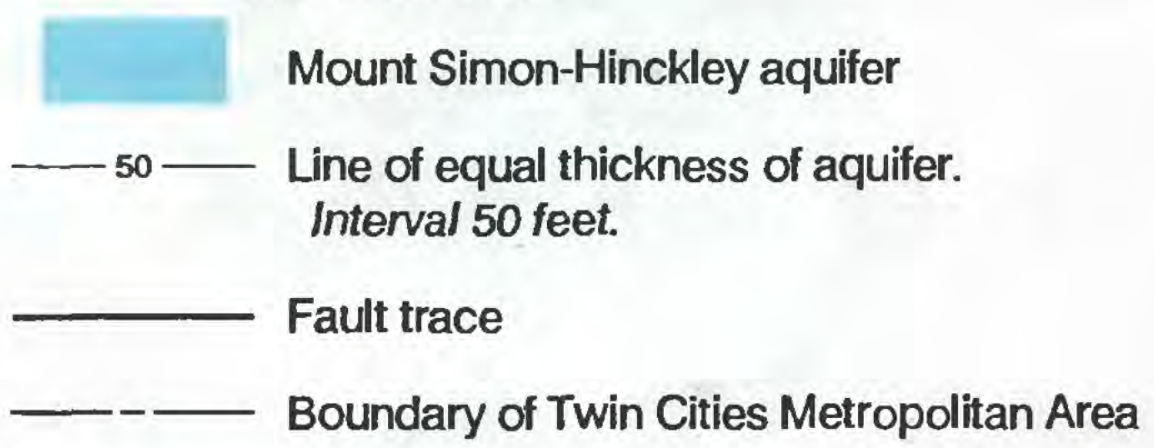

Figure 10.-Thickness of the Mount Simon-Hinckley aquifer 


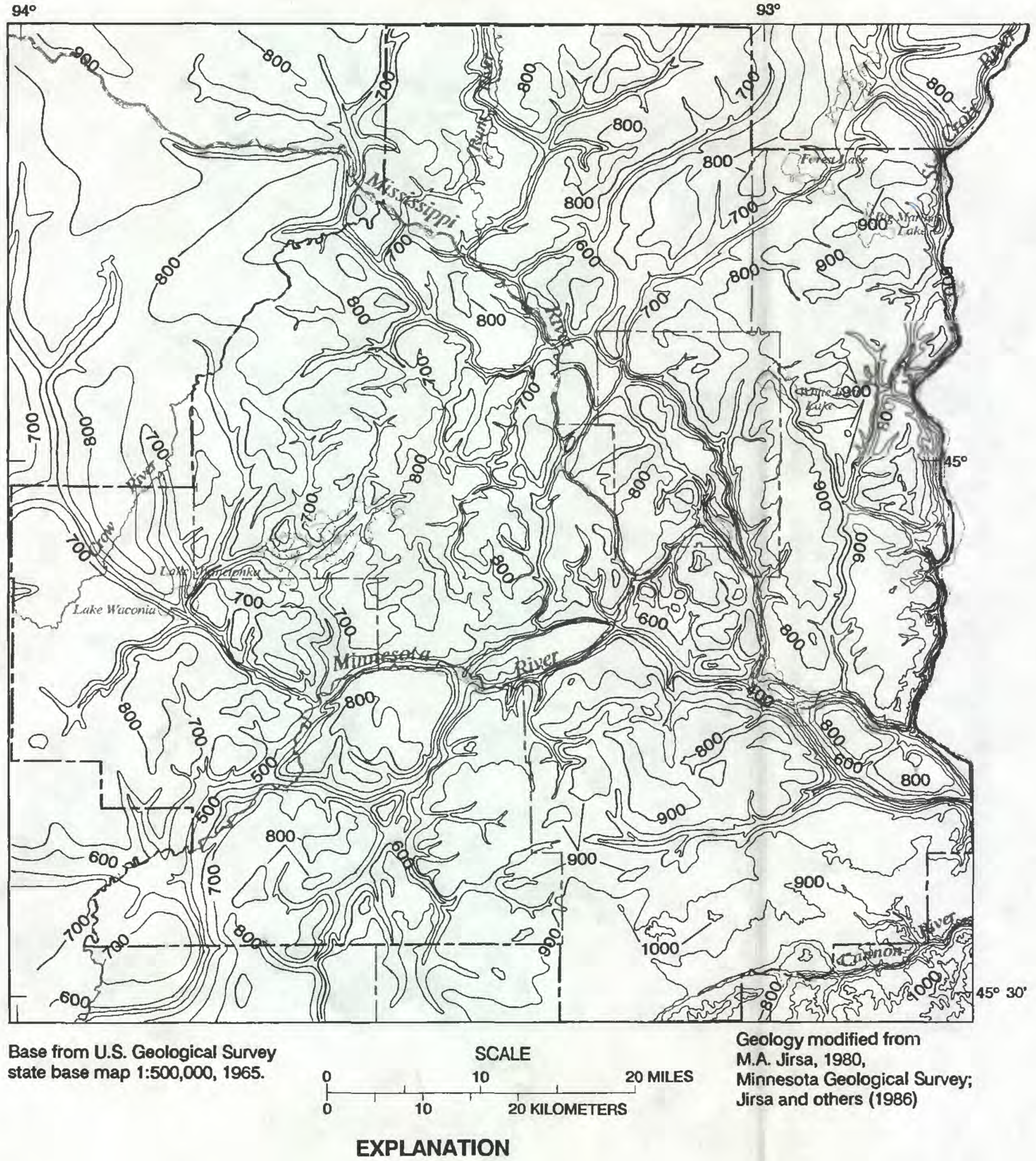

\section{$-800-$ Bedrock contour. Shows approximate altitude of bedrock surface. Contour interval 100 feet. Datum is sea level.}

Boundary of Twin Cities Metropolitan Area

Figure 11.--Configuration of the bedrock surface. 


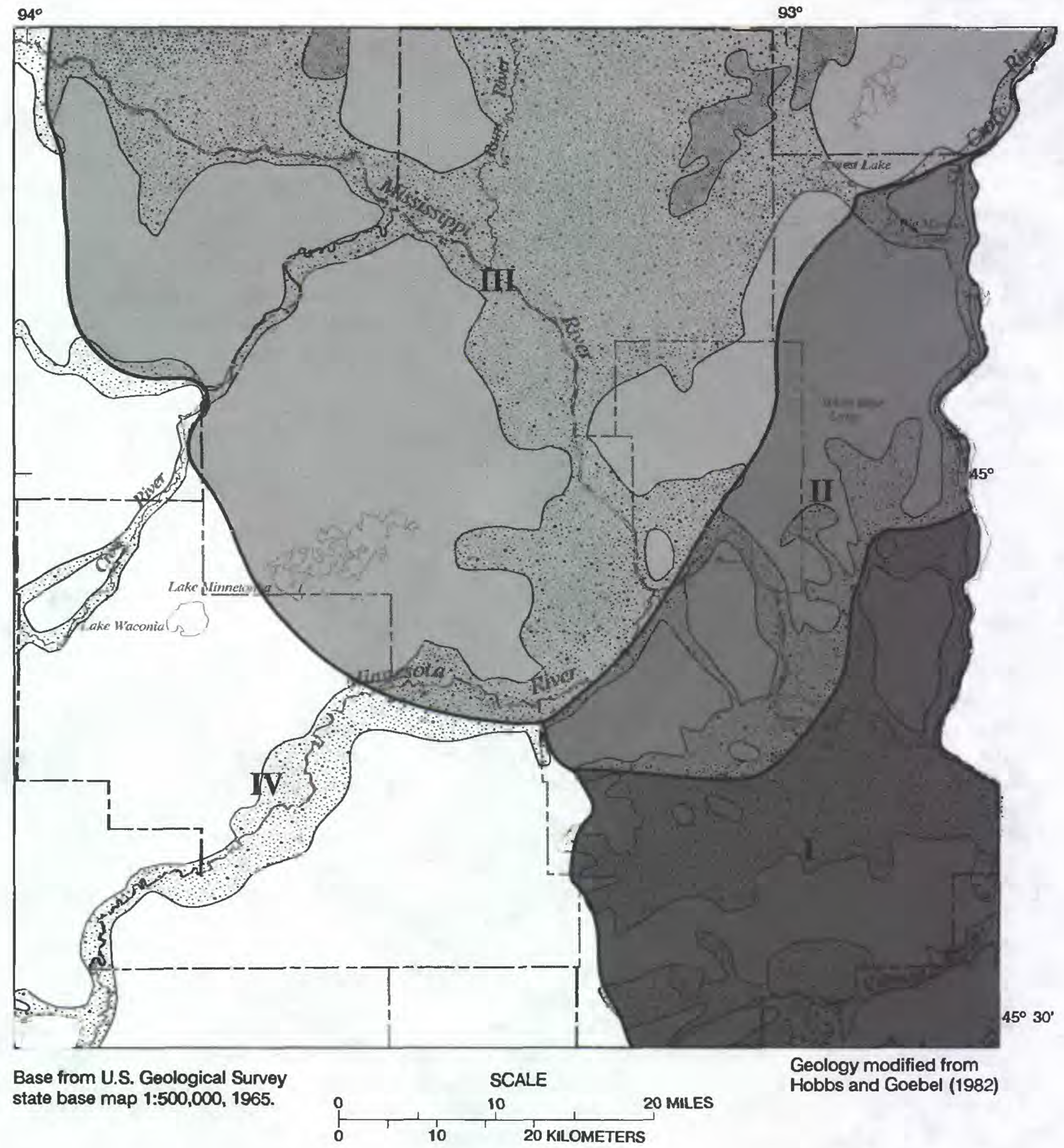

\section{EXPLANATION}

IV Des Moines lobe deposits overlying pre-Wisconsin surface

III Des Moines lobe glacial deposits over Superior lobe glacial deposits and pre-Wisconsin surface

II Superior lobe glacial deposits overlying pre-Wisconsin surface

Pre-Wisconsin drift and residuum over bedrock, overlain locally by Superior and Des Moines lobe outwash

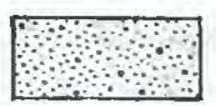

Sand, coarse to fine, mixed with silt, occurring as glacial outwash, river terrace deposits, and alluvium

Clay to sandy, boulder-like clay, present as glacial till

Organic clay to sandy clay, present as peat

$\therefore \therefore \quad$ Clay to boulders, unsorted, present as colluvium

Boundary of Twin Cities Metropolitan Area

Figure 12.- Distribution of types of glacial deposits. 


\section{Recharge}

Recharge to the ground-water system occurs mainly as infiltration of precipitation and percolation through the unsaturated zone to the water table. Evapotranspiration data (Baker and others, 1979, p. 6, 8, 10, 11; Kuehnast and others, 1975, p. 6-8) suggest that, of the 26 to $32 \mathrm{in} / \mathrm{yr}$ (inch per year) of precipitation on the study area, about 7 to $9 \mathrm{in} / \mathrm{yr}$ are available for recharge and overland runoff. Long-term stream-discharge records (1935-87) for the Twin Cities area (U.S. Geological Survey National Water-Data Storage and Retrieval System files) indicate that annual basin discharge (overland runoff plus ground-water discharge to streams) is 3.21 to $7.77 \mathrm{in} / \mathrm{yr}$ (table 2), based on statistics for minimum (3.21 in/yr), mean (5.46 in/yr), and median ( 7.77 in/yr) annual basin discharge. Annual basin discharge is calculated by dividing the annual surface-water flow through the basin by the area of the drainage basin.

The ground-water component of basin discharge is most easily estimated for the months of December through February, when overland runoff in the study area approaches or is equal to zero and ground-water flow to streams constitutes all of the basin discharge. The lowest value of monthly basin discharge for December through February ( 0.28 in.) is used as an estimate of groundwater discharge for those months. Ground-water flow to streams could be reduced during periods of large spring runoff (March and April) because river stage rises relative to the ground-water hydraulic head. The lower value of monthly basin discharge for March and April ( 0.25 in., table 2) is used as an estimate of ground-water flow to streams for those months. For the remaining months (May through November), the lowest value of monthly basin discharge for those months ( 0.39 in.) is used as an estimate of ground-water flow to streams. Estimated annual ground-water flow to streams is 1.60 to $4.30 \mathrm{in} / \mathrm{yr}$ (table 2), based on statistics for minimum ( $1.6 \mathrm{in} / \mathrm{yr})$, mean $(4.07 \mathrm{in} / \mathrm{yr})$, and median ( $4.30 \mathrm{in} / \mathrm{yr}$ ) estimated ground-water discharge in response to net basin discharge. For the months March through November, the mean and median values probably incorporate some component of overland runoff for some months and exclude some component of ground-water discharge for others. The minimum value of estimated ground-water flow to streams probably understates the total ground-water contribution because it incorporates extreme events such as droughts. Maximum streamflow discharge values indicate that water moves into either surface-water or ground-water storage or both under high-flow conditions. Consequently, it is reasonable to estimate that there is little or no ground-water discharge to the major rivers under high-flow conditions. Assuming that long-term ground-water recharge is approximately equal to long-term ground-water discharge to streams, recharge is about 1.5 to $4.5 \mathrm{in} / \mathrm{yr}$.

Lakes and wetlands represent locations where the water table intersects land surface. Ground water can flow in one side of these features and out the other (Brown, 1985). In addition, lakes and wetlands with control structures that raise their normal stage effectively store water that otherwise would have run off. As a result, the water table surrounding these lakes rises and leakage to the ground-water system from these lakes and wetlands can increase. Leakage occurs throughout the year and not just at the times of spring snowmelt and precipitation events. 


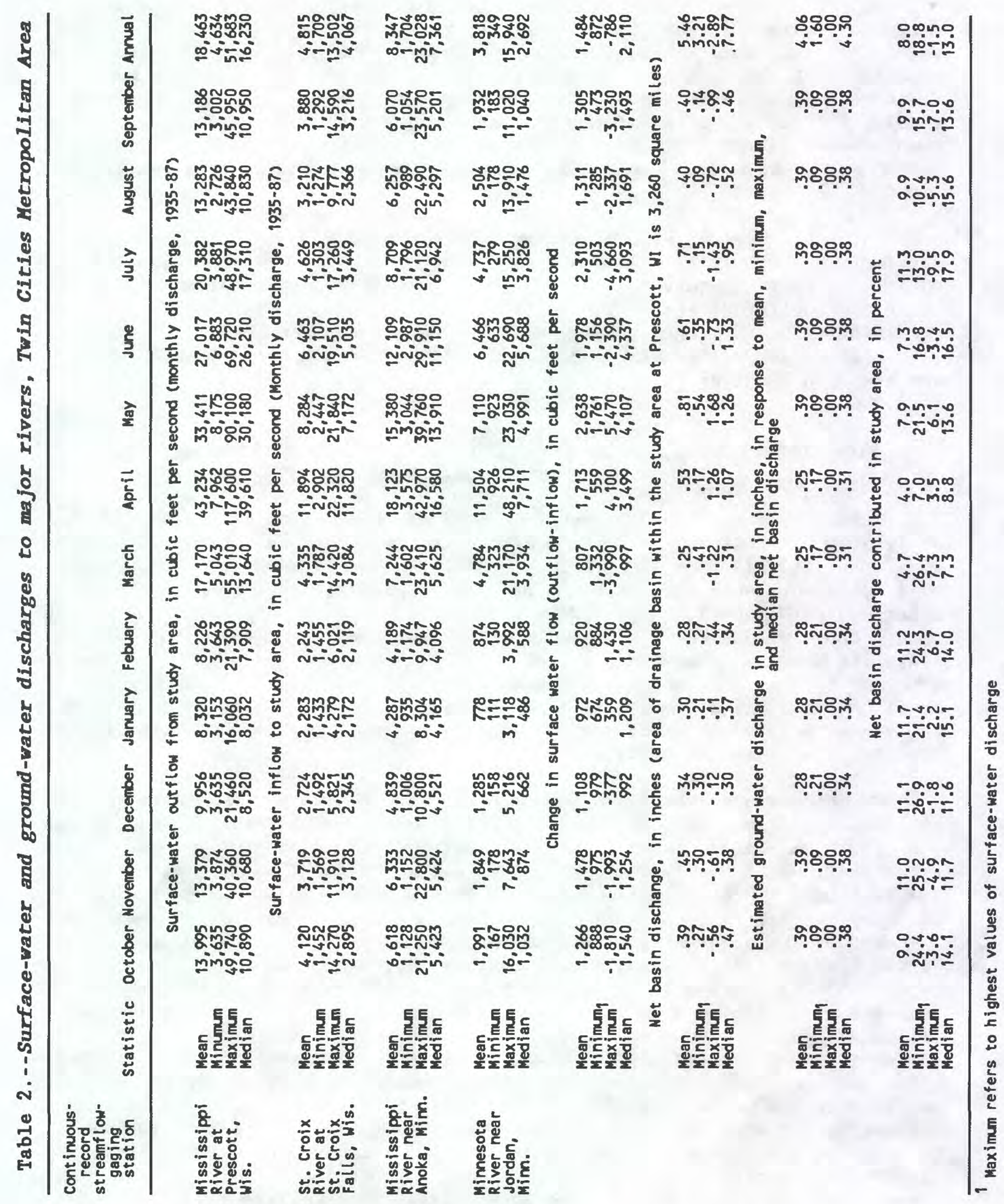


The distribution of sand plains and till plains affects the areal distribution of recharge. Precipitation infiltrates more rapidly through sand than through till. However, it also discharges more readily to local flow systems through sand than through till. Land-use practices also directly affect recharge. Increased urbanization has decreased wetland and wooded areas. Man-made surfaces such as concrete, asphalt, rooftops, and turf in urbanized areas tend to increase runoff, and sewering, which intercepts the increased runoff, further prevents infiltration of precipitation and percolation to the ground-water system. Changes in farming practices have increased overland runoff and decreased the potential for ground-water recharge from precipitation.

In areas of recharge, the movement of water is downward into the aquifer system. Where there is a good hydraulic connection between the surficial and underlying bedrock aquifers, and where the rate of recharge exceeds the ability of the aquifer to transport the water, the potentiometric surface rises. In the study area, ground-water mounds in bedrock aquifers occur under recharge areas associated with topographic highs in Washington, Dakota, Scott, and Hennepin Counties.

\section{Flow Through Principal Aquifers and Change in the Altitude of Their Potentiometric Surfaces}

Delineation of regional ground-water flow depends in part on the availability of reliable hydraulic-head data. In the study area, hydraulic-head data are available from about the year 1880 (predevelopment) to 1980 . Most early data were collected at times of well completion, pump repair, or well maintenance (Winche11, 1888). With each succeeding hydraulic-head survey, the number and areal extent of hydraulic-head measurements expanded. By 1980 , hydraulic heads were measured in about 700 wells in the seven-county study area and in five surrounding counties. Most of the wells in which measurements are made are used for municipal supply, air conditioning of commercial buildings, industrial processes, irrigation, or domestic supply; consequently, they are mostly active wells.

Known consequences of ground-water use from before the development of ground-water resources (1880) to 1980 can be used to evaluate potential consequences of increased ground-water use. Between 1880 and 1980, ground-water withdrawals caused long-term declines of water levels of as much as 90 feet in the Prairie du Chien-Jordan aquifer and $240 \mathrm{ft}$ in the deeper Mount SimonHinckley aquifer (Reeder, 1966). Long-term declines in the potentiometric surfaces of these deeper aquifers induce more water to recharge deeper parts of the aquifer system. As a result of this increased capture of recharge, the water table is lowered and a greater percentage of water flows through the deeper bedrock aquifers and is denied as discharge to small streams, seepage faces, and springs. Consequent1y, many of the springs and seeps reported in earlier times (Winche11, 1888; Thiel, 1944) can no longer be found. In addition, under certain conditions, increased pumpage may be great enough to cause declines in the potentiometeric surface which can induce water to leak from streams into the ground-water system. Consequently, sufficient long-term lowering of the potentiometric surface has the potential of reducing streamflow for navigation, for flushing of unwanted constituents and dilution of sewage, and for public supply. Moreover, leakage of surface water into aquif- 
ers may impair the chemical and bacteriological quality of the ground water. Large seasonal water-level changes caused by seasonally variable pumpage also can occur in the short term (Schoenberg, 1984, figs. 3 and 4).

Hydraulic-head data were available to describe the configuration of the potentiometric surfaces under predevelopment conditions and in 1949, 1959, 1965, 1970, 1977-78, and 1980 in the Prairie du Chien-Jordan and Mount SimonHinckley aquifers. Only the predevelopment and winter 1980 potentiometric surfaces and changes in the hydraulic head from predevelopment to winter 1965 and predevelopment to winter 1980 are discussed in this report. Predevelopment heads were calculated from data given by Reeder (1966). Heads in winter 1965 and winter 1980 were measured during January-March 1965 (Reeder, 1966) and January-March 1980 (Schoenberg, 1984).

\section{Prairie du Chien-Jordan Aquifer}

Hydraulic heads during predevelopment (fig. 13) indicate that ground water flowed from topographically controlled potentiometric highs (greater than $900 \mathrm{ft}$ above sea level) in northern Washington and central Hennepin Counties toward the major rivers, the Mississippi, Minnesota, and St. Croix. No predevelopment data were available for southern Scott and southern Dakota Counties. Similarly, hydraulic heads in winter 1980 (fig. 14) indicated that ground water flowed from topographically controlled potentiometric highs (greater than $900 \mathrm{ft}$ above sea leve1) in northern Washington, central Hennepin, southern Scott, and southern Dakota Counties toward the Mississippi, Minnesota, and St. Croix Rivers. This head configuration shows that the major rivers in the study area are the principal natural drains of ground water from the system.

At several locations, irregularly shaped or closed potentiometric contours indicate that major pumping centers disrupt the natural flow pattern in the Prairie du Chien-Jordan aquifer by diverting ground water enroute from the potentiomentic highs to the major rivers. In some areas, such as near the depression on the potentiometric surface in southwestern Ramsey County, pumping may have reversed the natural direction of flow and caused water from the Mississippi River to enter the aquifer. However, despite ground-water pumpage that averaged about $154 \mathrm{Mgal} / \mathrm{d}$ from 1976 through 1979 (Horn, 1983, table 7), the potentiometric surface of the Prairie du Chien-Jordan aquifer reflects no large cones of depression. In addition, ground-water divides closely parallel surface-water divides. This suggests that, on a regional scale, overlying confining units play a small role in determining ground-water flow in the Prairie du Chien-Jordan aquifer and that the aquifer is highly transmissive and in good hydraulic connection both with the overlying drift and the major rivers.

Long-term declines in the potentiometric surface of about $60 \mathrm{ft}$ have occurred in the Prairie du Chien-Jordan aquifer from predevelopment to 1965 (fig. 15) as a result of pumpage (Reeder, 1966). Changes in the altitude of the potentiometric surface between 1965 (Reeder, 1966) and 1980 (Schoenberg, 1984) have been minor. A hydrograph for the Prairie du Chien-Jordan aquifer for 1961-80 (fig. 16) shows repetitive, seasonal water-level changes in response to seasonally varying pumpage. 

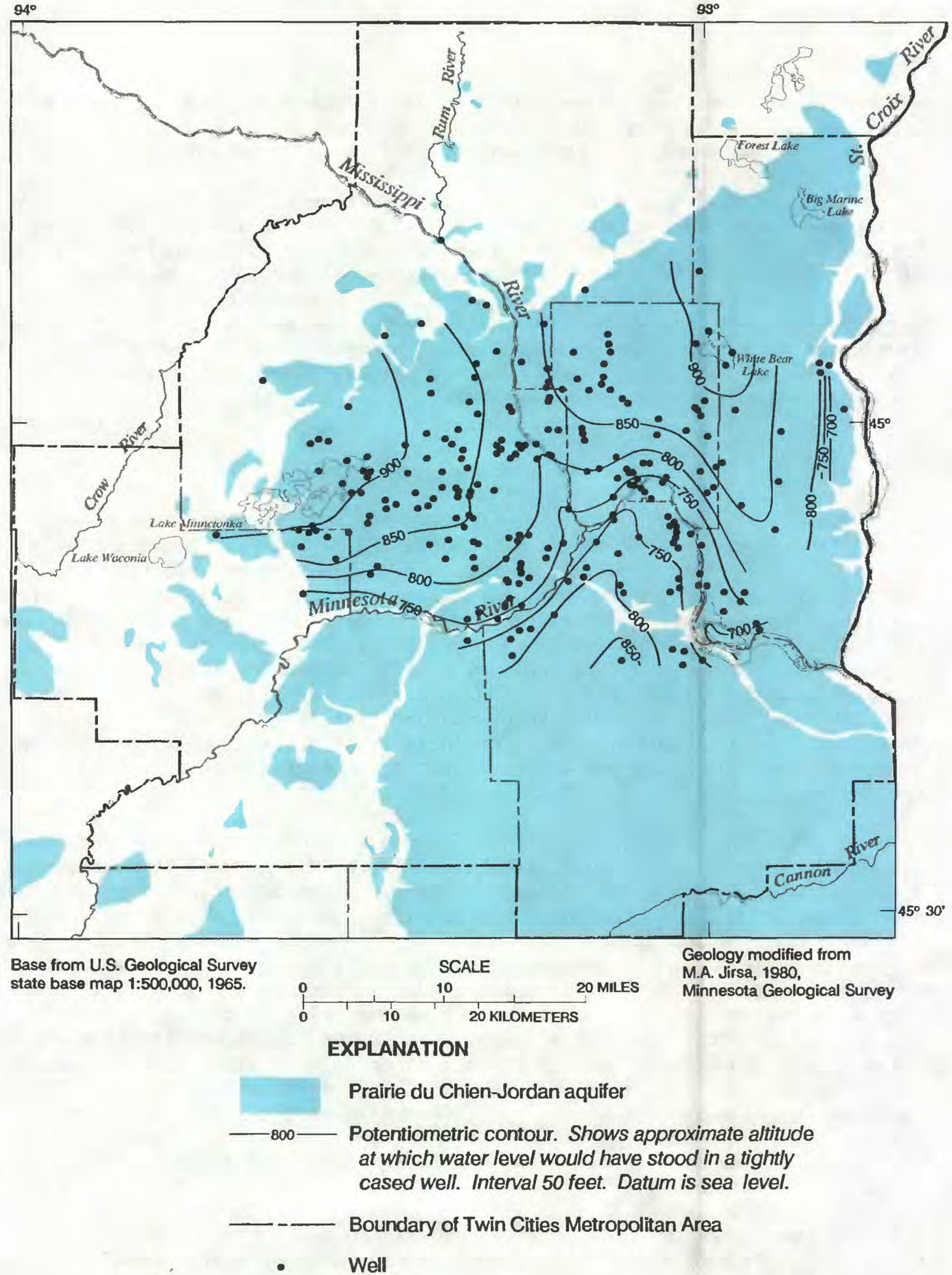

Figure 13.-Predevelopment potentiometric surface, Prairie du Chien-Jordan aquifer. 


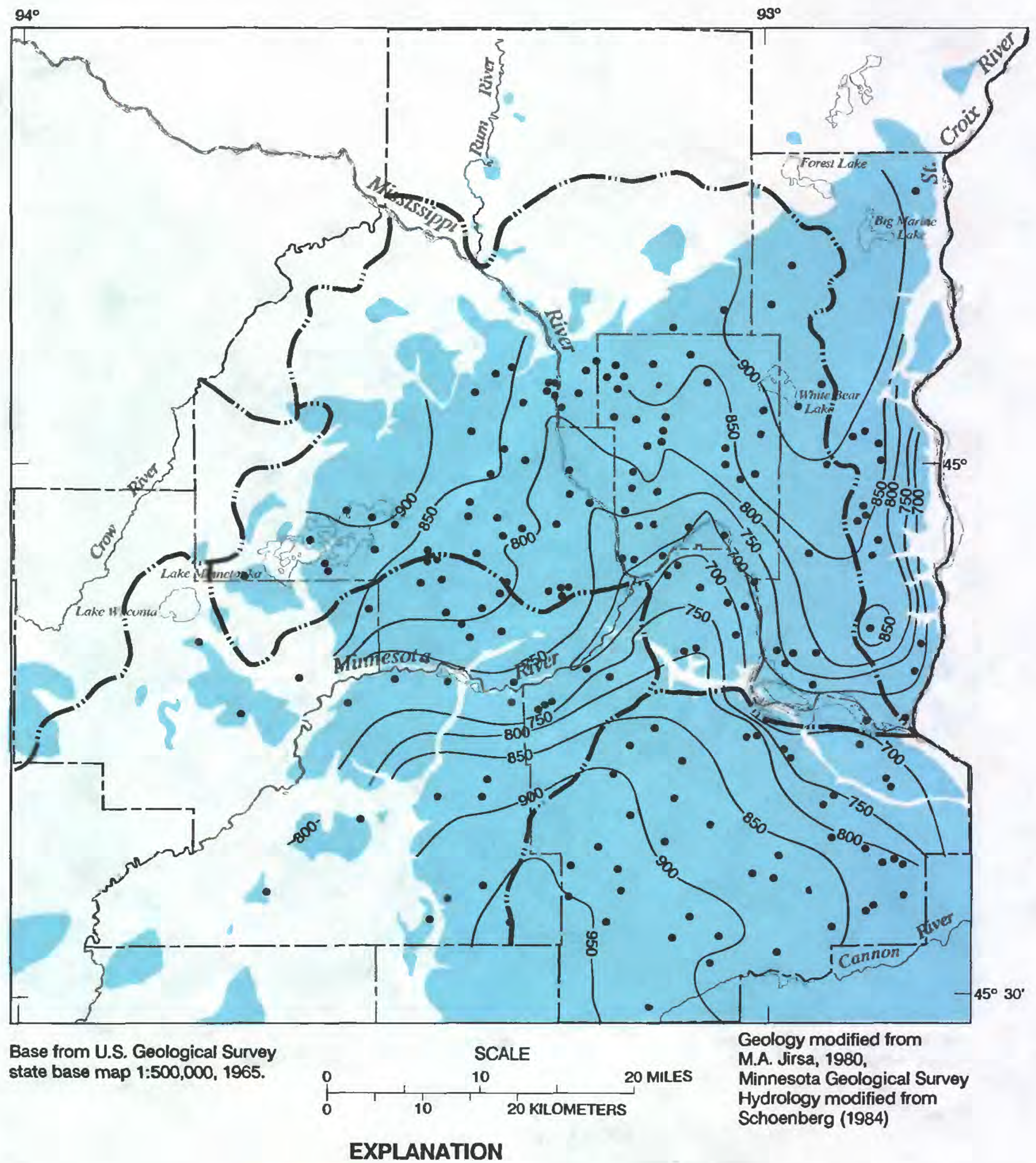

Prairie du Chien-Jordan aquifer

$\longrightarrow 700-$ Potentiometric contour. Shows approximate altitude at which water level would have stood in a tightly cased well. Interval 50 feet. Datum is sea level.

Boundary of Twin Cities Metropolitan Area

Watershed boundary

- Well

Figure 14.--Potentiometric surface during winter 1980, Prairie du Chien-Jordan aquifer. 


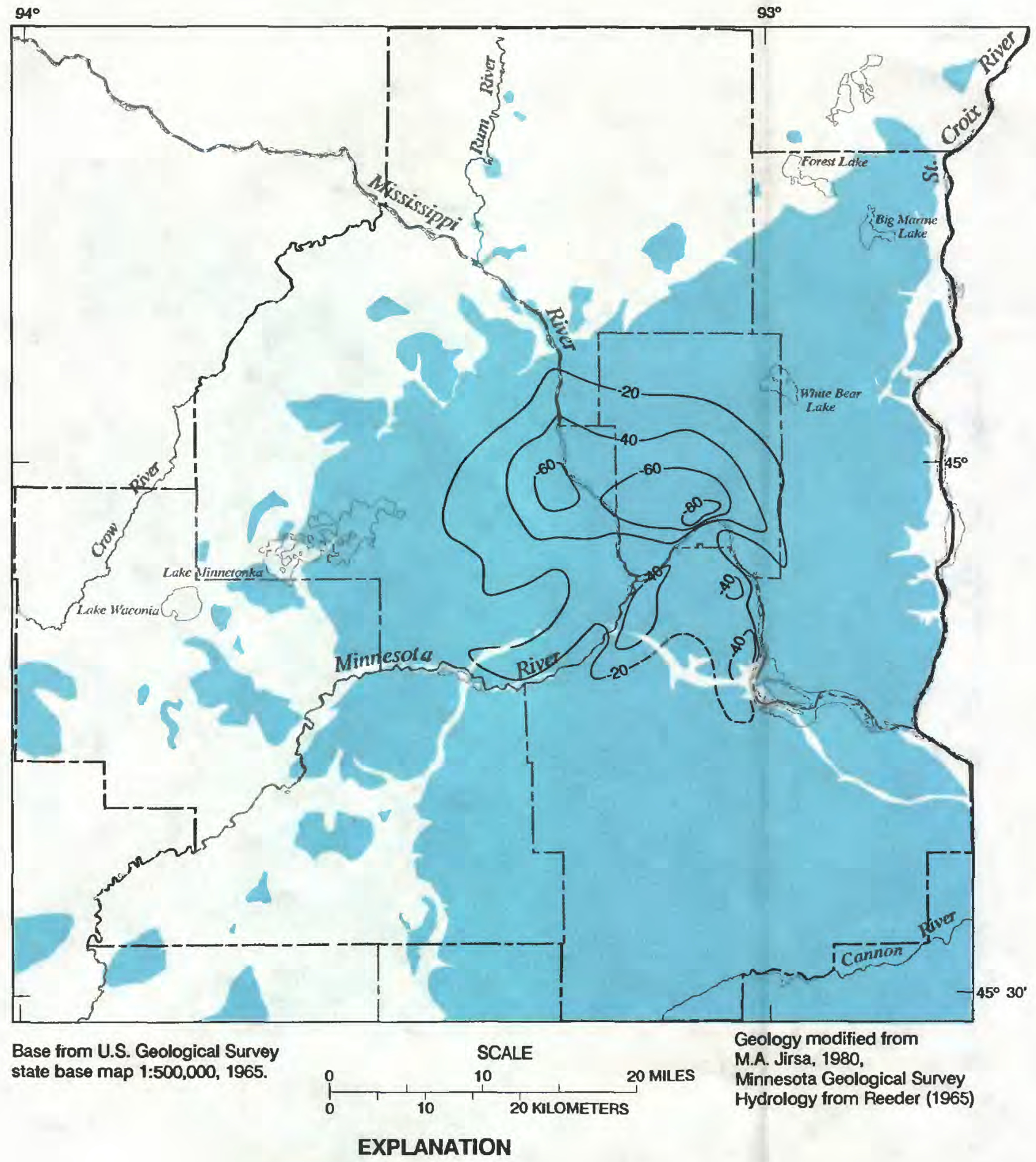

Prairie du Chien-Jordan aquifer

-60 L Line of approximate equal change in water level. Interval 20 feet. Dashed where approximate.

Boundary of Twin Cities Metropolitan Area

Figure 15.--Change in the altitude of the potentiometric surface of the Prairie du Chien-Jordan aquifer from predevelopment to 1965. 


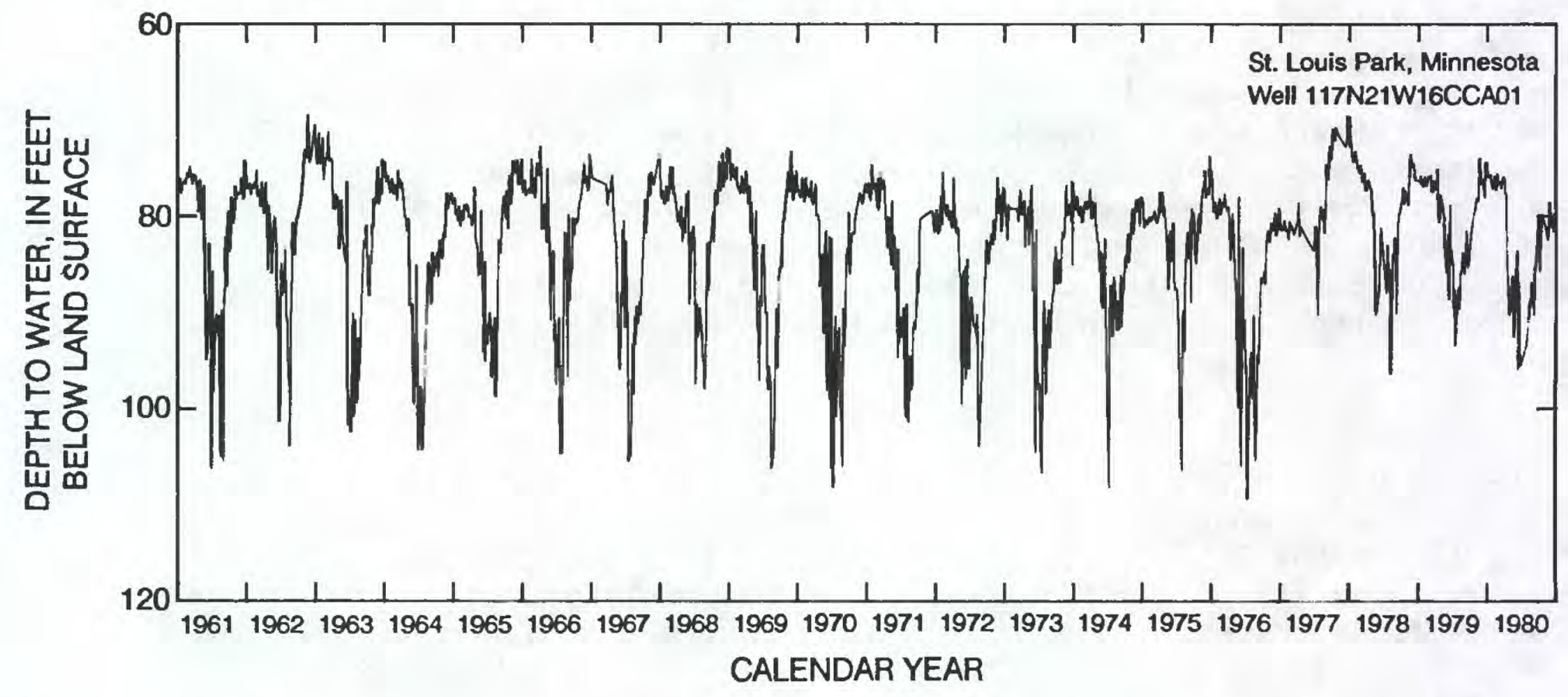

Figure 16.--Hydrograph of well open to the Prairie du Chien-Jordan aquifer, Twin Cities Metropolitan Area, 1961-80. 
Comparison of the distribution of heads in the Prairie du Chien-Jordan aquifer for predevelopment and either winter 1965 (fig. 15) or winter 1980 (fig. 17) show declines in excess of $25 \mathrm{ft}$ over wide areas in southeastern Hennepin County, the southern two-thirds of Ramsey County, and the northern fringe of Dakota County along the Minnesota and Mississippi Rivers. Declines locally exceeded $50 \mathrm{ft}$ in Hennepin County near Minnetonka and the eastern end of the boundary between Edina and St. Louis Park. A large area of decline in excess of $50 \mathrm{ft}$ occurred along the Mississippi River near downtown Minneapolis, along the Minnesota River from Burnsville to its confluence with the Mississippi River, and over much of southern Ramsey and northern Dakota Counties. The declines associated with Ramsey and Dakota Counties center about the Mississippi River and the City of St. Paul.

\section{Mount Simon-Hinckley Aquifer}

Hydraulic heads indicate that the natural, predevelopment flow of ground water in the Mount Simon-Hinckley aquifer (fig. 18) was from a topographically controlled potentiometric high in the northwest corner of the study area (greater than $900 \mathrm{ft}$ above sea level) east to the St. Croix and Mississippi Rivers. Hydraulic heads in winter 1980 (fig. 19) indicate that ground water now moves from the same topographically controlled potentiometric high in the northwestern part of the study area southeasterly toward the Minnesota and Mississippi Rivers and toward a large cone of depression. In addition, in winter 1980, ground water moved toward the cone (1) north from a potentiometric high south of the study area (Delin and Woodward, 1985, p. 38) and (2) west from eastern Washington County near the St. Croix River (Schoenberg, 1984).

During winter 1981 , the cone of depression in the potentiometric surface in the Mount Simon-Hinckley aquifer was about $25 \mathrm{mi}$ in diameter and 100 to 150 ft deep (Schoenberg, 1984, pl. 2A). The cone of depression encircles major pumping centers in St. Louis Park and Edina (Hennepin County) and in St. Paul (southern Ramsey County). Moreover, wells and pumping centers that represent sites of significant withdrawals from the Mount Simon-Hinckley aquifer are scattered throughout the study area (Horn, 1983, fig. 13) and all contribute to development of the cone.

Long-term declines in the altitude of the potentiometric surface of as much as $240 \mathrm{ft}$ have occurred in the Mount Simon-Hinckley aquifer from predevelopment to 1965 (fig. 20) (Reeder, 1966). Changes in that altitude have been minor between 1965 (fig. 20) and 1980 (fig. 21). Comparison of the predevelopment head distribution with winter 1965 and winter 1980 head distributions indicate that head declines in excess of $50 \mathrm{ft}$ occurred over much of southeastern Hennepin, southern Anoka, northwestern Washington, and parts of Dakota, Scott, and Carver Counties. A hydrograph for 1961-80 (fig. 22) shows a rapid, annual, inverse response between water levels and pumpage. Note that the pumpage scale is inverted. 


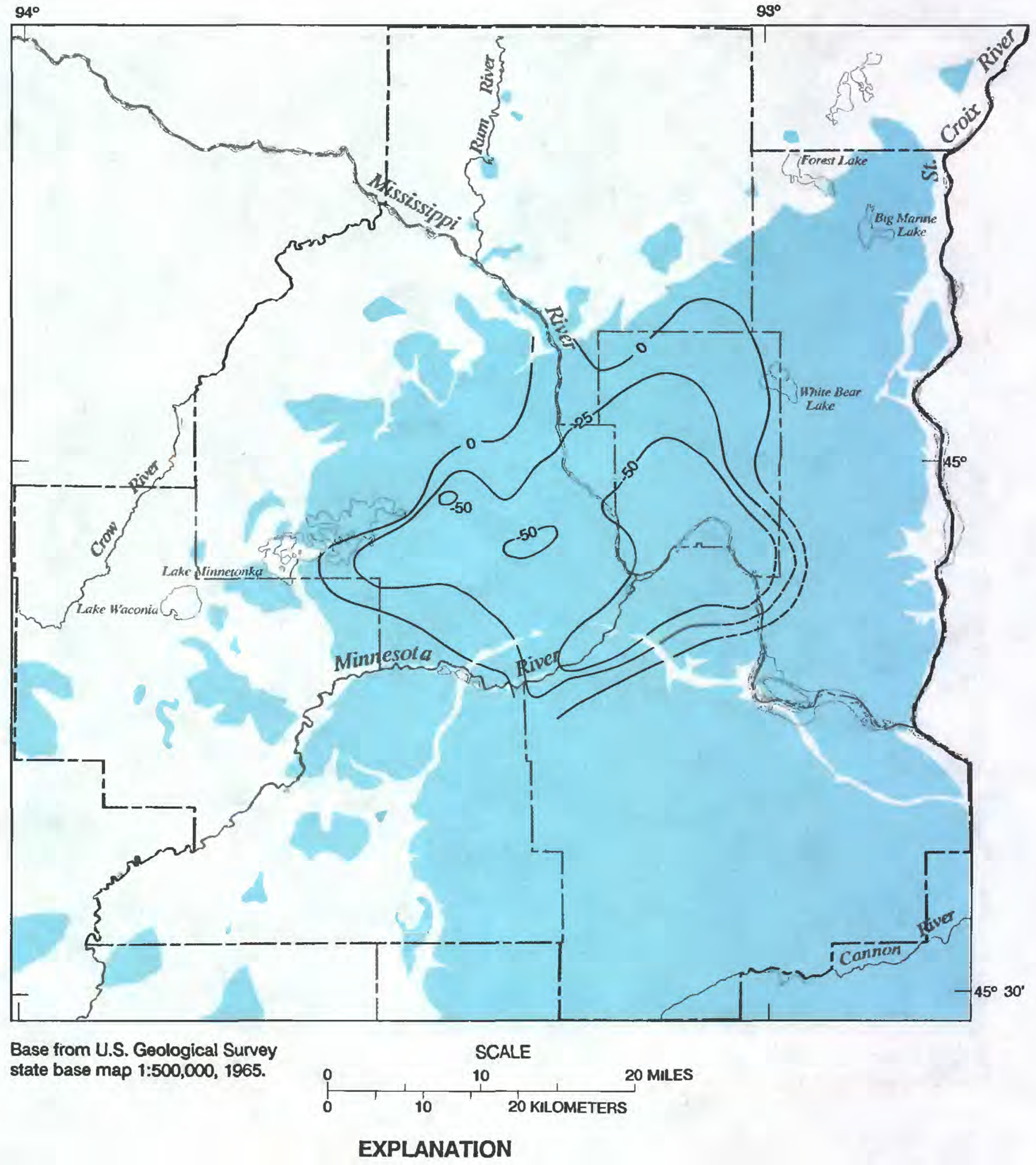

Prairie du Chien-Jordan aquifer

- 25 - Line of equal water-level decline. Interval 25

feet. Dashed where approximate.

- Boundary of Twin Cities Metropolitan Area

Figure 17.-Change in altitude of the potentiometric surface of the Prairie du ChienJordan aquifer from predevelopment to winter 1980, Twin Cities Metropolitan Area.

(Based on contours from potentiometrlc maps from predevelopment and winter 1980.) 


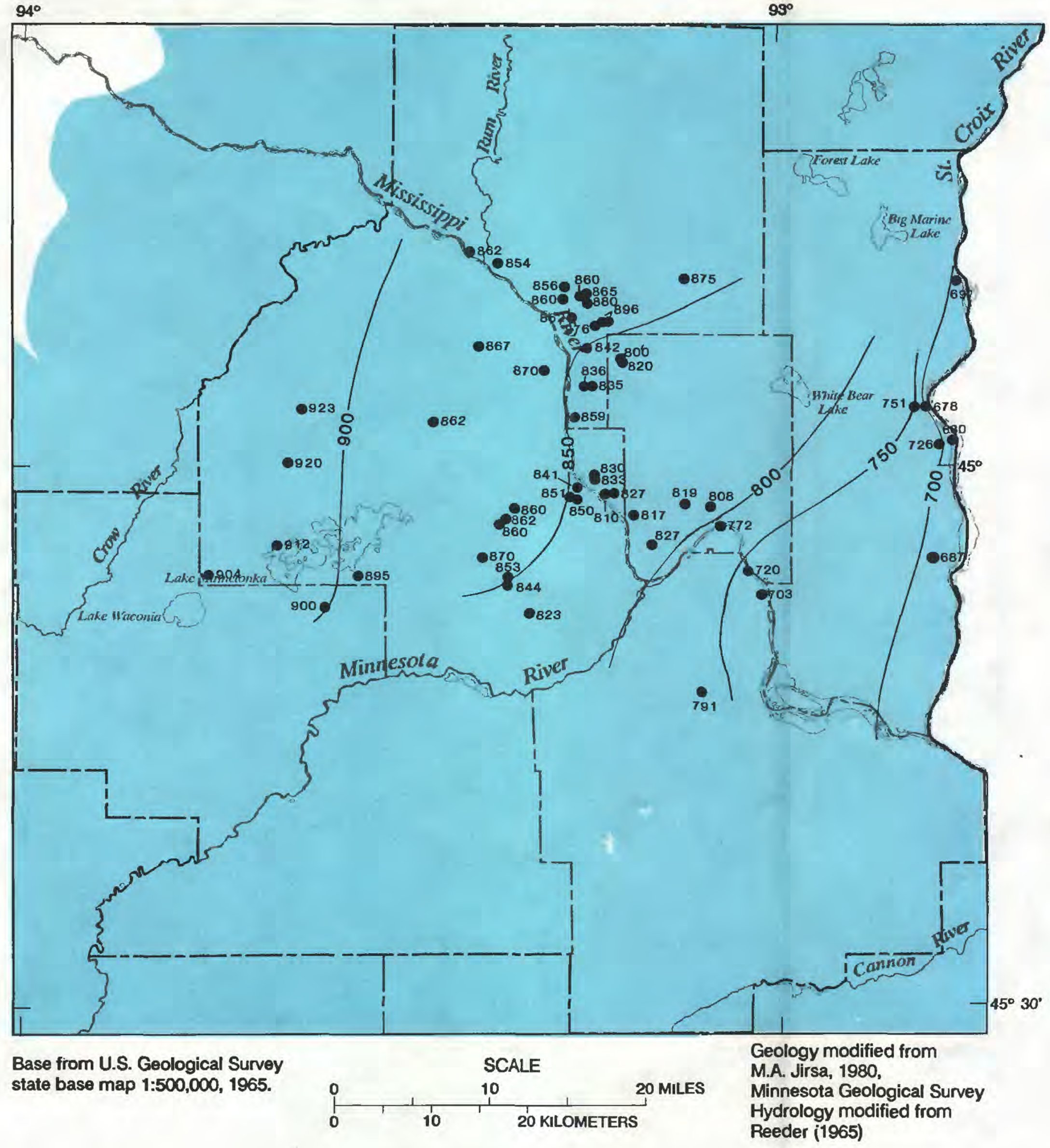

EXPLANATION

Mount Simon-Hinckley aquifer

-800 Potentiometric contour. Shows approximate altitude at which water level would have stood in a tightly cased well. Interval 50 feet. Datum is sea level.

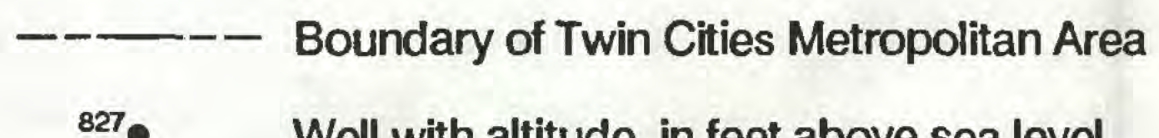

827. Well with altitude, in feet above sea level

Figure 18.-Predevelopment potentiometric surface, Mount Simon-Hinckley aquifer. 


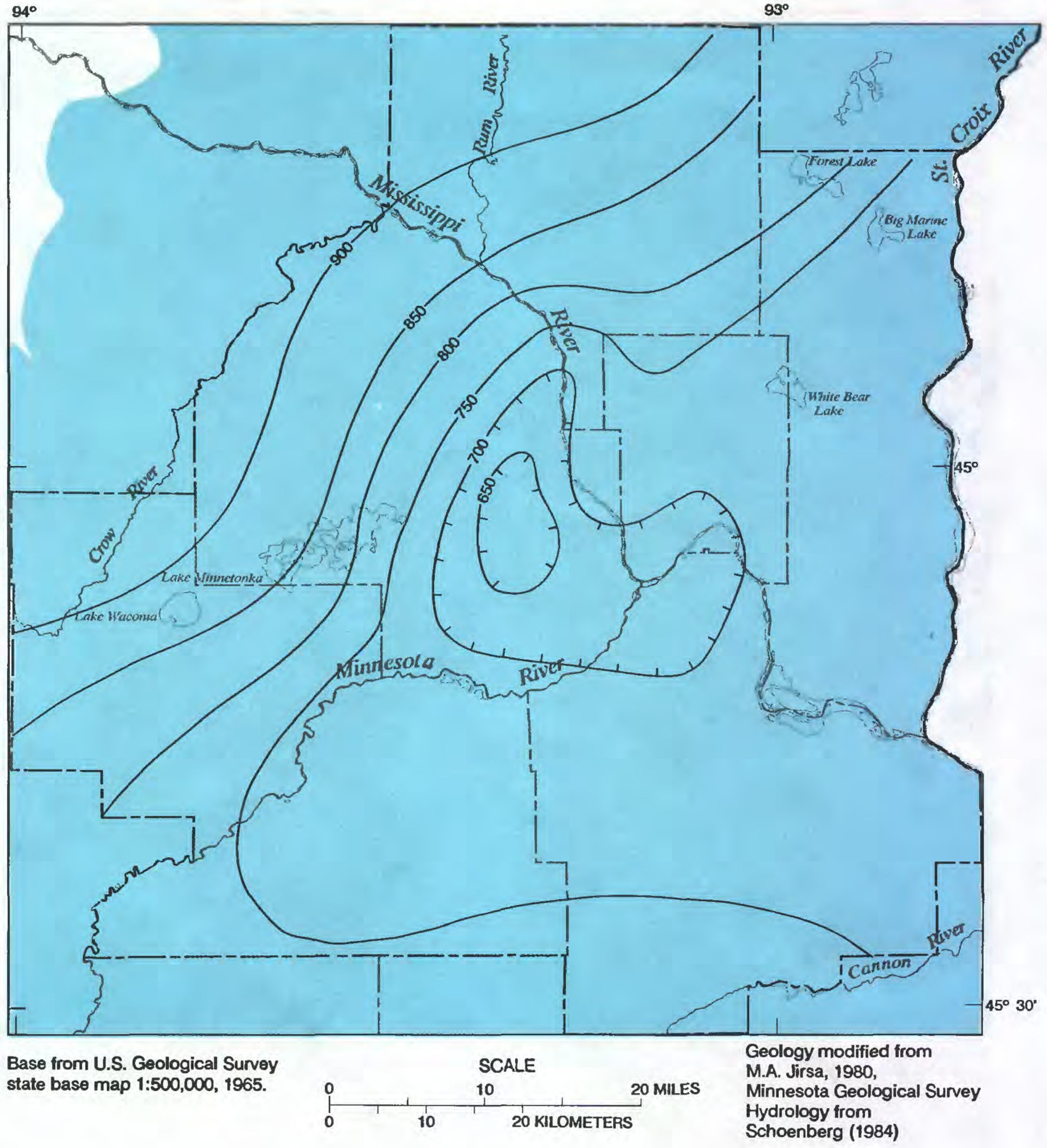

\section{EXPLANATION}

Mount Simon-Hinckley aquifer

$-700-$ Potentiometric contour. Shows approximate altitude at which water level would have stood in a tightly cased well. Hachured lines indicate area within a cone of depression. Interval 50 feet. Datum is sea level.

Boundary of Twin Cities Metropolitan Area

Figure 19.--Potentiometric surface during winter 1980, Mount Simon-Hinckley aquifer. 


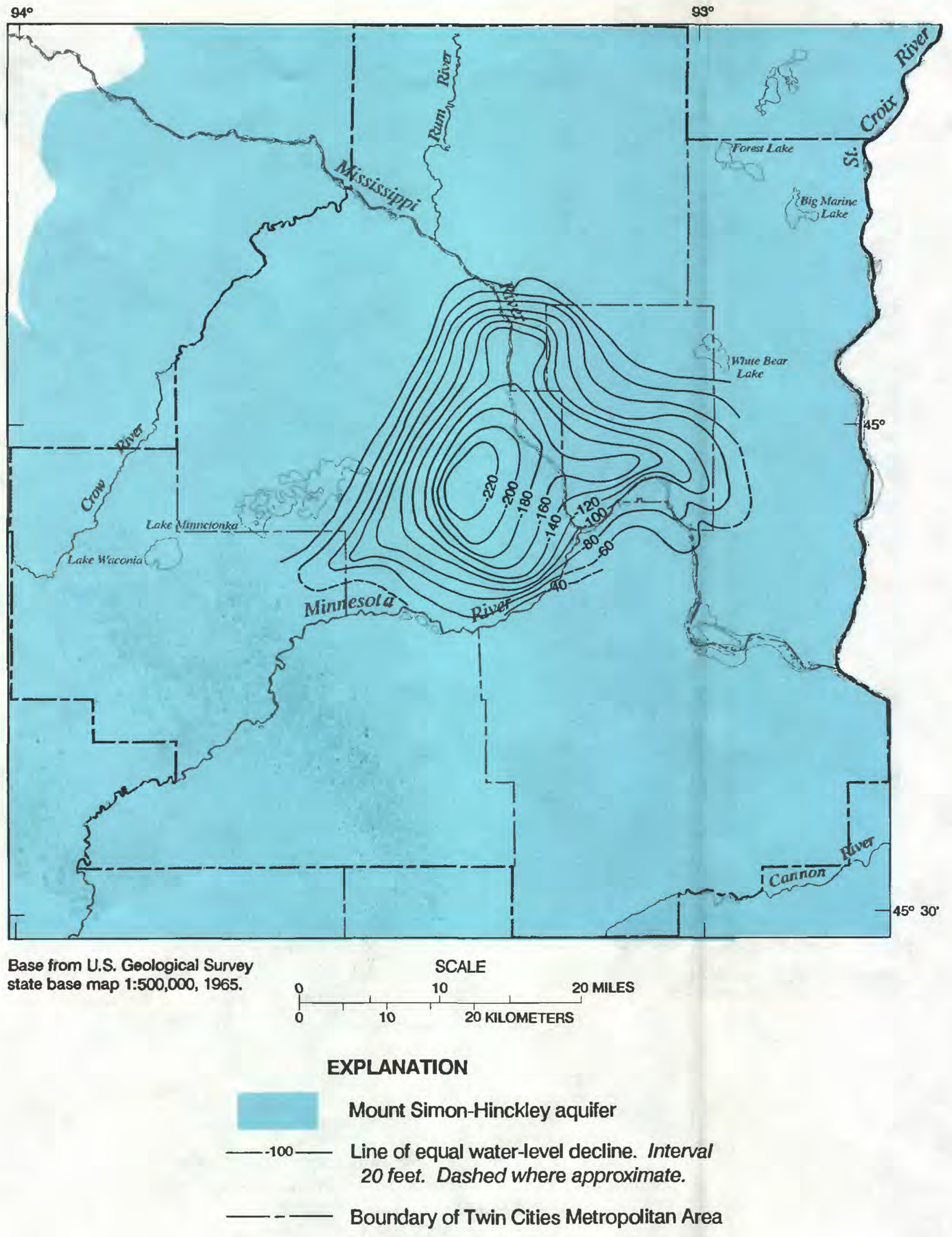

Figure 20.--Change in altitude of the potentiometric surface of the Mount SimonHinckley aquifer from predevelopment to 1965.

(Reeder, 1965) 

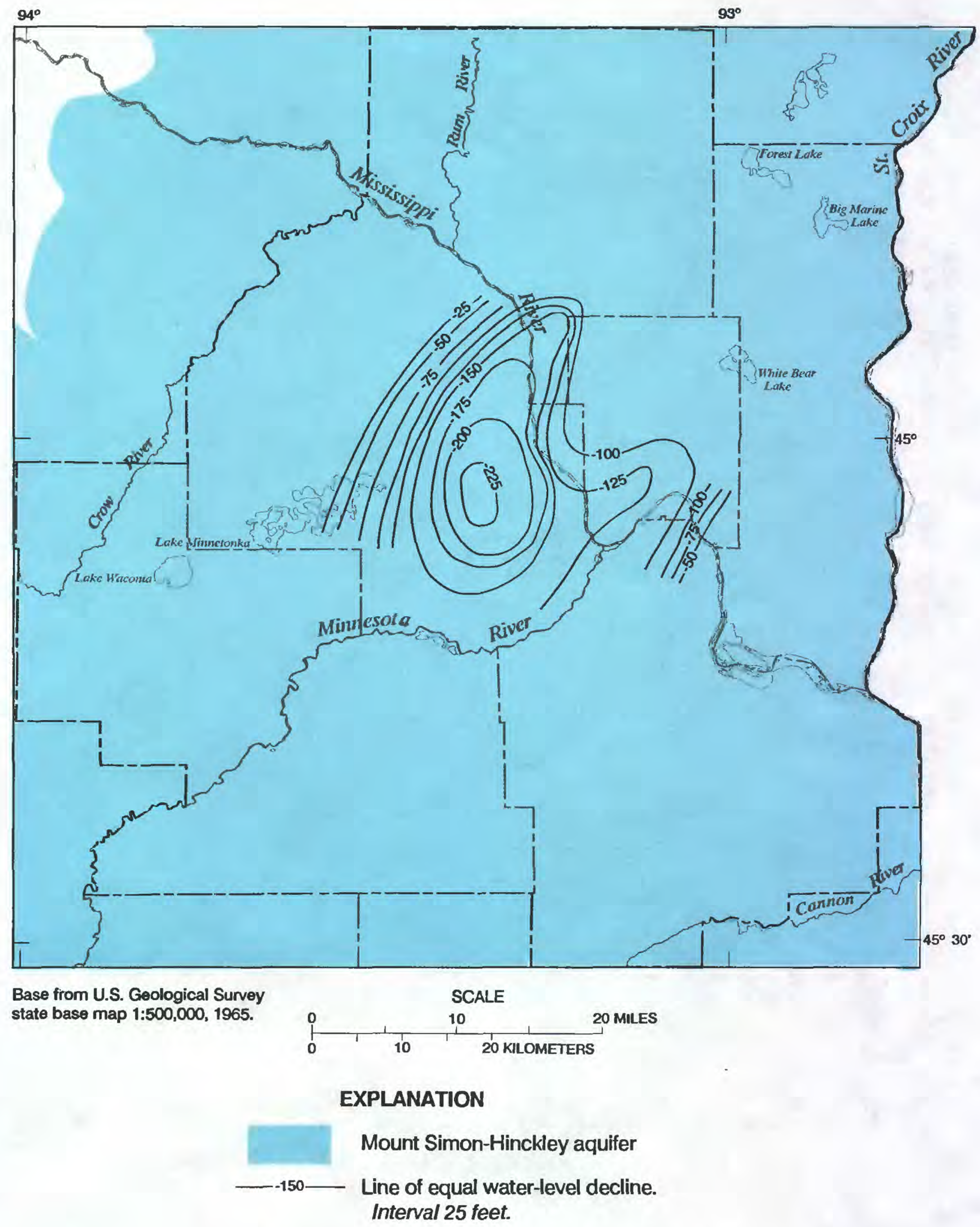

Boundary of Twin Cities Metropolitan Area

Figure 21.-Change in altitude of the potentiometric surface of the Mount Simon-Hinckley aquifer from predevelopment to winter 1980, Twin Cities Metropolitan Area. (Based on contours from potentiometric maps for predevelopment and winter 1980.) 

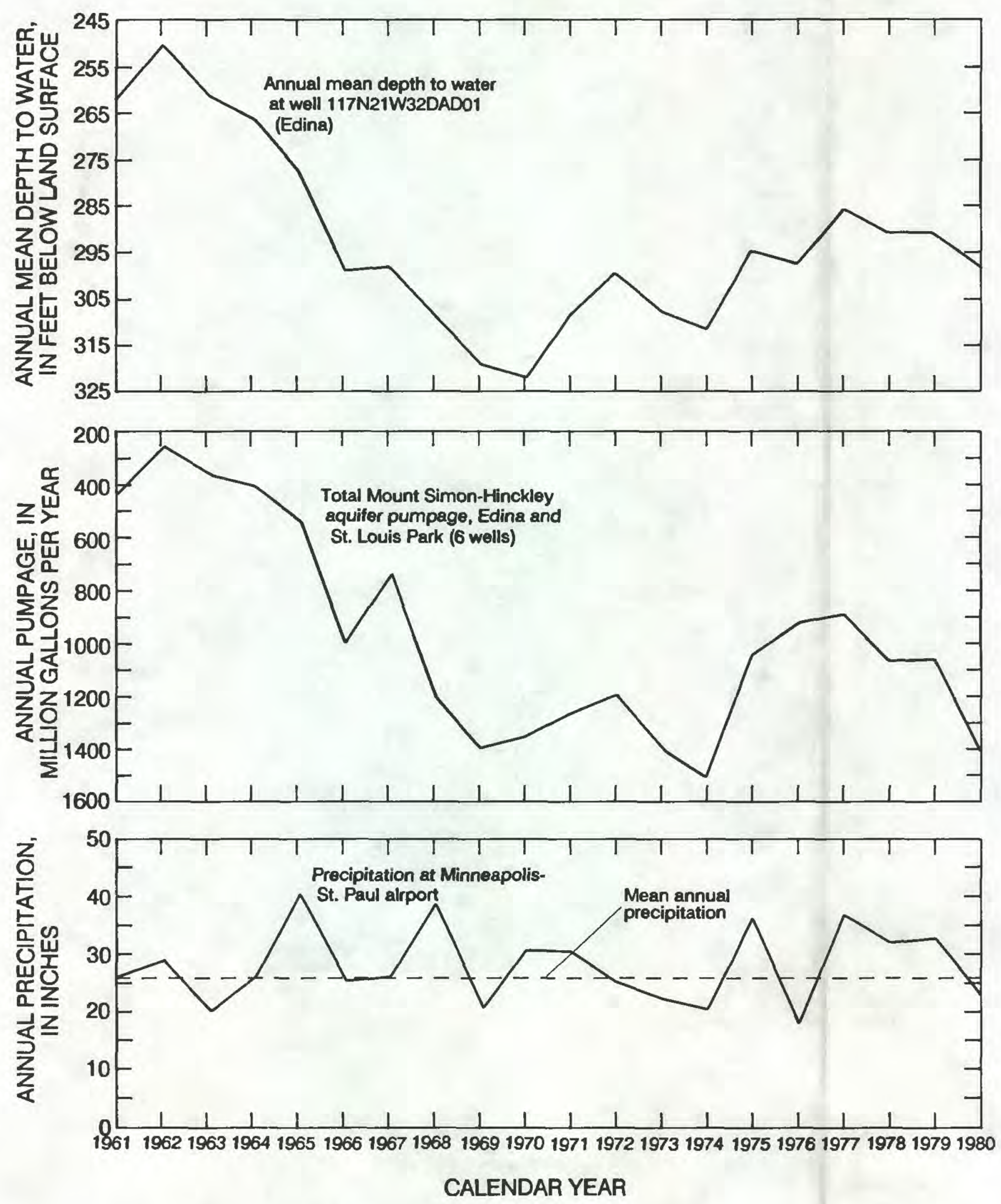

Figure 22.-Comparison of water levels, pumpage in the Mount Simon-Hinckley aquifer, and precipitation in the Twin Cities Metropolitan Area. 


\section{Discharge}

The major rivers are important natural hydraulic boundaries for each aquifer from the Ironton-Galesville through the drift. In addition, the St. Croix River is an important hydraulic boundary for the Mount Simon-Hinckley aquifer. The minor rivers are hydraulic boundaries for the drift aquifer as well as whichever bedrock aquifer immediately underlies the drift in the vicinity of the stream. Ground water typically flows into and out of a river through its bottom and sides. In some areas, ground water discharges to streams through seepage faces.

Alluvium in major river valleys tends to consist of repeated layers of fine silt, fine-grained sand, and clay cut by thick layers of coarse-grained stream-channel fill (fig. 23). Ground water travels more easily horizontally than vertically in alluvium and can more readily leak in and out through the sides of the river valleys than through the bottom. Leakage into and out of rivers is not only a function of alluvial and river-bed materials, but also a function of the difference in head between ground water in adjacent aquifers and the stage of the river. When the ground-water head is higher than the river stage, ground water will flow into the river. When the situation is reversed, river water will flow into the aquifer.

Springs and seepage faces occur along the sides of valleys. Springs may be found at various levels along steep-sided cliffs typical of the study area where a more transmissive layer in an aquifer overlies a less transmissive layer, typically a confining unit. Water tends to flow along the contact between the two layers. A seepage face occurs when water issues from the face of a steep-sided cliff over a wide, diffuse area but does not coalesce to form a spring. For both springs and seepage faces, the direction of water movement is one way--from the ground-water system to the stream. When the ground-water level drops below the altitude at which seepage or spring flow can occur, this discharge from the ground-water system to the stream ceases.

Flow through seepage faces or springs creates an overlying unsaturated zone within an aquifer (fig. 23). This zone goes from the face of the cliff back to the confined-unconfined boundary in the aquifer. The size of the unsaturated zone depends on the hydraulic characteristics and geometry of both the aquifer and the cliff face. The higher the transmissivity of the aquifer, the farther into the aquifer the unsaturated zone will extend. In several places in the study area, unsaturated zones extend 2 to $3 \mathrm{mi}$ into the aquifer (figs. 5 and 6 ). Discharge of water can be retarded by clogged pore spaces due to weathering of the cliff face or damming by ice during winter.

Ground-water discharge from aquifers to streams in the study area is a significant part of streamflow. The significance is shown by discharge of the Mississippi River at Prescott, Wisconsin, in January, which solely reflects ground-water discharge through valley-fill deposits. Analysis of data from gaging stations that define stream-flow in the study area shows that during January 1977 (a dry year) (U.S. Geological Survey, 1978) and January 1982 (a wet year) (Gunard and others, 1983) ground-water discharge contributed about 25 and 15 percent, respectively, of the mean monthly flow of the Mississippi River where it exits the study area. 


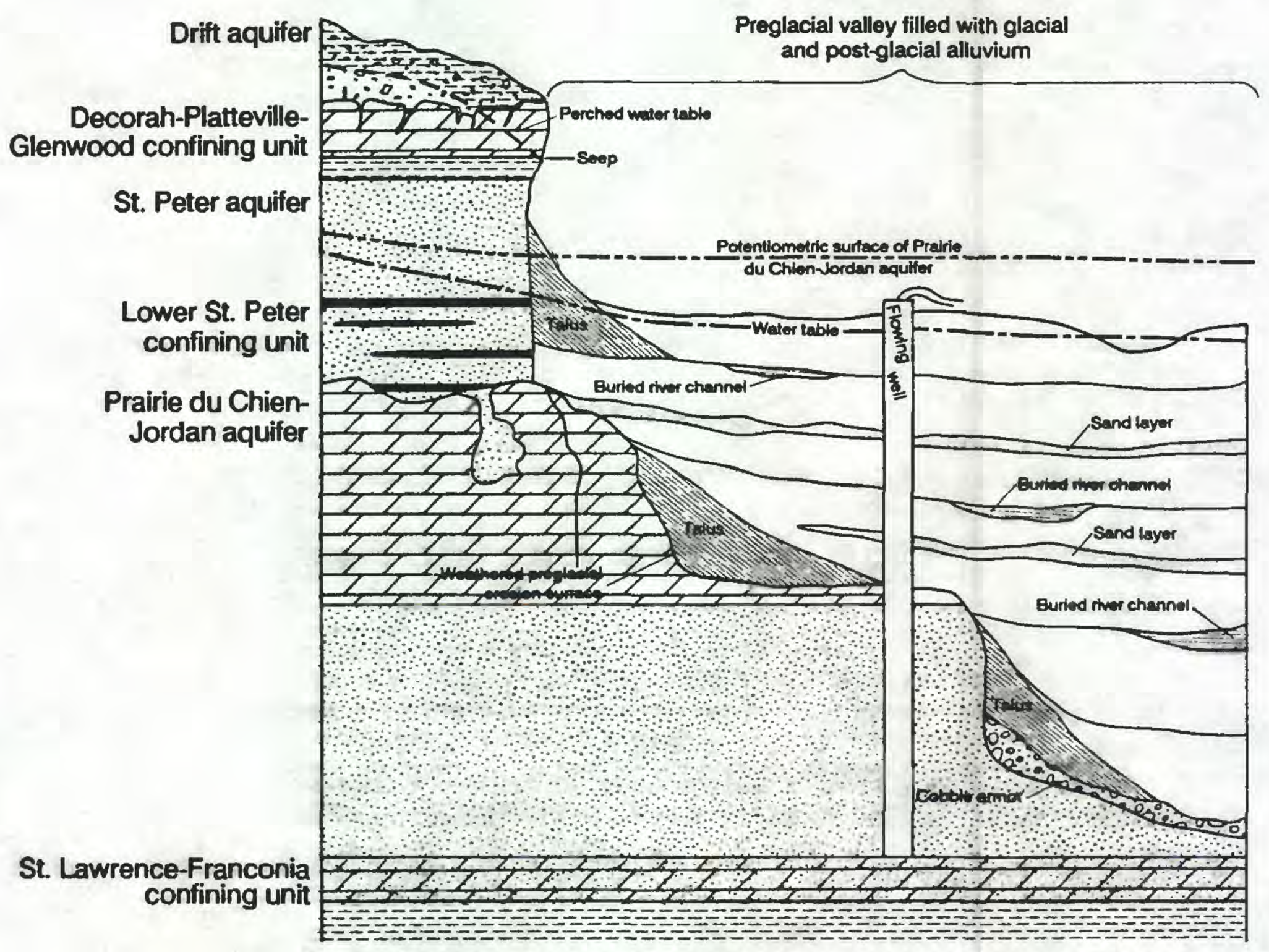

Note: Nl structures and material not specifically labeled are finely laminated, fine sand and silt with clay.

Figure 23.-Schematic hydrogeologic section of a typical river valley. 
Leakage between streams and ground water can vary seasonally because of floods and summer pumpage. Floods, which generally occur during spring, raise stream stage relative to the ground-water level in the banks surrounding the stream. As a result, ground-water flow to the river is either slowed or reversed. During summers, increased pumpage for air-conditioning, irrigation, and municipal supply reduces the availability of ground water and, consequent$1 y$, the rate of ground-water discharge to the streams. Under certain conditions, increased pumpage may be great enough to reverse normal gradients and induce water from the streams into the ground-water system.

Discharge of rivers in the study area has been recorded since the late $1890^{\prime} \mathrm{s}$. Records for the period 1935-87 suggest that the mean discharge from the ground-water system to the streams is about $4 \mathrm{in} / \mathrm{yr}$, or about $1,000 \mathrm{ft}^{3} / \mathrm{s}$ (table 2).

Determining the amount and areal distribution of ground-water use in the study area was vital to this study because, along with natural ground-water recharge and discharge, pumping is the principal hydrologic stress on the ground-water system. For example, compared to a recharge rate of $3.5 \mathrm{in} / \mathrm{yr}$ (or about $600 \mathrm{Mgal} / \mathrm{d}$ of water), ground-water use in 1980 amounted to about 200 $\mathrm{Mgal} / \mathrm{d}$.

Horn (1983) described available water-use data for 1880 to 1980 . Data from 1880 to 1970 were compiled as 10 or 20-year averaged values. Detailed water-use data were expanded from data complied for 1976 and 1978 (Guswa and others, 1983) to data for about 1,000 wells for 1970-79. The annual groundwater-use data for 1970-79 was obtained from records at the Minnesota Department of Natural Resources and other State and municipal agencies, or estimated on the basis of use at similar installations. Monthly data were recorded for 1970-79 when available. Statistical analysis was used to estimate monthly data for individual wells where only annual pumpage data were available. All data were stored in a computerized hierarchical data base (Horn, 1984, fig. 4). A plot of ground-water use for 1880 to 1980 (fig. 24) shows that withdrawals increased steeply from about $1 \mathrm{Mgal} / \mathrm{d}$ in 1880 to about $200 \mathrm{Mgal} / \mathrm{d}$ in the late $1960^{\prime} \mathrm{s}$, when it stabilized.

\section{Boundary Conditions of Aquifers}

The boundary conditions described in this section are the locations where water enters and leaves each aquifer. Each aquifer is described separately. Glacial drift usually contains the water table, the upper boundary of the aquifer system, and it directly affects that part of precipitation that infiltrates to the water table and recharges the aquifer system. Some water in the drift is diverted by shallow ground-water-flow systems that discharge to minor rivers such as the Rum, Crow, and Cannon Rivers or as seepage through bluffs at places along the Minnesota and Mississippi Rivers. The rest leaks out of the drift into deeper ground-water flow systems. Ground water also moves upward through the drift from bedrock aquifers and discharges as leakage to the Minnesota, Mississippi, and St. Croix Rivers. In addition, glacial drift controls rates of leakage of water between underlying bedrock aquifers and lakes and wetlands. 


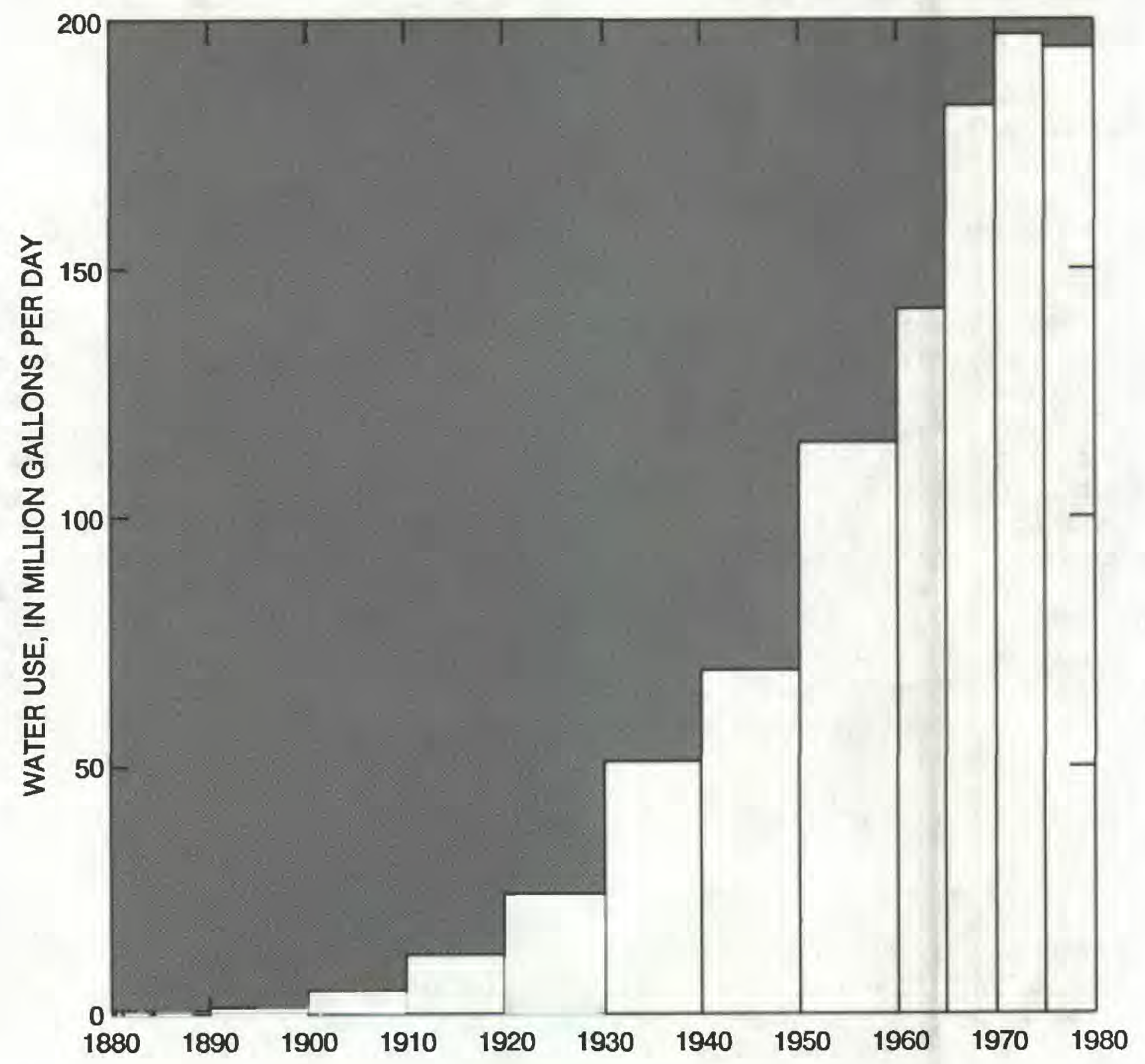

Figure 24.-Ground-water withdrawals from all aquifers, 1880-1980.

(from Horn, 1983, p. 30) 
The St. Peter aquifer receives water as leakage directly through overlying drift and through buried bedrock valleys. Ground water leaks between the aquifer and the overlying Decorah-Platteville-Glenwood and underlying lower St. Peter confining units, the flow moving from higher to lower hydraulic heads. Ground water from the aquifer discharges as leakage to the Cannon River along the southern boundary of the study area and as leakage to river bottoms or seepage through bluffs along the present-day valleys of the Minnesota, Mississippi, and St. Croix Rivers. A ground-water divide separates flow to the Mississippi and flow to the St. Croix Rivers where the aquifer underlies a topographic divide in Washington County. Locally, this hydrogeologic unit is unconfined and may be completely above the water table (fig. 5).

The Prairie du Chien-Jordan aquifer receives water as leakage directly through overlying drift and buried bedrock valleys. Ground water leaks between the aquifer and the overlying lower St. Peter and underlying St. Lawrence-Franconia confining units. Ground water from the aquifer dischaiges as leakage to the Cannon River and a series of lakes and wetlands along the southern boundary of the study area and as leakage to river bottoms or seepage through bluffs along the present-day valleys of the Minnesota, Mississippi, and St. Croix Rivers. Ground-water divides separate flow to the Mississippi and St. Croix Rivers, where the aquifer underlies a topographic divide in Washington County, and to the Mississippi and Minnesota Rivers, where the aquifer underlies topographic divides in Dakota and Hennepin Counties. Local1y, along the Minnesota, Mississippi and St. Croix Rivers, the aquifer is unconfined.

The Ironton-Galesville aquifer receives water as leakage through directly overlying drift and buried bedrock valleys. Ground water leaks between the aquifer and the overlying St. Lawrence-Franconia and underlying Eau Claire confining unit. Ground water discharges as leakage through overlying bedrock aquifers and drift to the Cannon and Minnesota Rivers and wetlands and lakes along the southern boundary of the study area and as leakage into the St. Croix and Mississippi Rivers (downstream from Hastings and where the river enters the seven-county area from the north). A flow divide in the aquifer occurs south of the Twin Cities Metropolitan Area in southern LeSueur, Rice, and Goodhue Counties where there is a topographic divide. Ground water divides separate flow to the Mississippi and St. Croix Rivers, where the aquifer underlies a topographic divide in Washington County, and to the Mississippi and Minnesota Rivers, where the aquifer underlies topographic divides in Dakota and Hennepin Counties.

The Mount Simon-Hinckley receives water as leakage directly through overlying drift. Ground water leaks between the aquifer and the overlying Eau Claire confining unit. Ground water discharges as leakage through overlying hydrogeologic units into the St. Croix and Mississippi Rivers along the eastern boundary of the study area and into the Mississippi River where the river enters the seven-county area from the north. A flow divide in the aquifer occurs south of the Twin Cities Metropolitan Area in southern LeSueur, Rice, and Goodhue Counties where there is a topographic divide. Ground water is assumed not to leak from underlying rocks across the base of the aquifer, making the base the lower external boundary of the aquifer system. 


\section{Conceptual Model}

Conceptual models qualitatively summarize the major physical and hydraulic characteristics of aquifer systems and form the basis for simplifying assumptions that facilitate computer modeling. Such models describe cause and effect relationships between stresses and the distribution of head. However, conceptual models give only the flavor of the extremely varied interactions in a geologically and hydraulically complex environment such as an aquifer system. Major elements and assumptions used in the conceptual model of the Twin Cities aquifer system are as follows:

(1) Aquifers are recharged by precipitation that infiltrates the ground and percolates to the saturated zone;

(2) Water is withdrawn from each of the aquifers in the system either by pumpage or natural discharge;

(3) The amount of water that moves across the base of the Hinckley Sandstone is sma11;

(4) Water flows between the aquifer system and the Mississippi, Minnesota, and St. Croix Rivers as a function of the difference between aquifer head and river stage;

(5) Aquifers discharge water through springs and seepage faces along the Mississippi, Minnesota, and St. Croix Rivers;

(6) Natural boundaries for some of the hydrogeologic units of the aquifer system are located beyond the boundaries of the study area.

(7) Ground-water flow in aquifers and confining units is considered to be horizontal and vertical, respectively, with the aquifers linked by leakage through the confining units.

(8) Overland runoff can be viewed as rejected recharge; that is, the capacity for ground-water recharge must be met before runoff occurs and, as the capacity for recharge increases, less water becomes available to run off.

(9) The aquifer system can be considered to have been in dynamic equilibrium for the period 1965-80 because changes in the altitude of the potentiometric surfaces of the two principal aquifers from predevelopment during that period are minor.

\section{EFFECTS OF PRESENT GROUND-WATER WITHDRAWALS}

The effects of present ground-water withdrawals were simulated using a ground-water flow model based on the Trescott (1975) and Trescott and Larson (1976) computer code. Mathematical models of ground-water flow provide quantitative information on the effects of complex and dynamic variations in natural and man-made stresses on the ground-water system. Additionally, quantitative models provide a tool for combining and analyzing massive amounts of complex data. A model of this type has the desirable characteristic of simulating all important processes that affect ground-water flow. The level of detail incorporated into the model is determined both by the degree of 
resolution needed to portray the complex behavior of the aquifer system and the availability of data (after Cosby and others, 1985, p.51).

The model constructed for this study resulted from a three-phase approach that included (1) preliminary modeling by Guswa and others (1983), (2) a period of additional data collection on water use and water levels (Horn, 1983; Schoenberg, 1984), and (3) construction of the current model. The preliminary model identified increased needs for accurate water levels and water-level-change data, water-use data, and a detailed physical description of the hydrologic system. Initial analysis indicated that the preliminary model was most sensitive to recharge, pumpage, and flow through the drift and semiconfining units to heavily pumped areas. Parts of the aquifer system that needed to be modeled in greater detail also were identified. The results of further analysis of water-level and water-use data were briefly described in previous sections. See Horn (1983) and Schoenberg (1984) for additional detail.

The numerical model constructed for this study was calibrated under equilibrium (steady-state) conditions for the period 1970-79. Calibration procedures and model response during calibration are described. Before the model could be used to simulate possible future conditions, it was necessary to (1) interpret the steady-state results in terms of differences between model results and behavior of the real aquifer system and (2) analyze model sensitivity to changes in modeled variables.

\section{Mathematical Basis for the Numerical Model}

The equations of three-dimensional flow of ground water provide a mathematical tool in which the properties of the aquifer system can be quantitatively related. For confined aquifers, Trescott (1975, P. 4) gives the equation as,

$$
\frac{\partial\left(\mathrm{T}_{x x} \frac{\partial h}{\partial x}\right)}{\partial x}+\frac{\partial\left(T_{y y} \frac{\partial h}{\partial y}\right)}{\partial y}+\frac{\partial\left(b_{z z} \frac{\partial h}{\partial z}\right)}{\partial z}=S^{\prime} \frac{\partial h}{\partial t}+b W(x, y, z, t)
$$

where

$\mathrm{h}$ is the hydraulic head [L]

$\mathrm{T}_{\mathrm{xx}}, \mathrm{T}_{\mathrm{yy}}$ are the principal components of the transmissivity tensor $\left[\mathrm{L}^{2} \mathrm{~T}^{-1}\right]$

$S^{\prime} \quad$ is the storage coefficient [dimensionless]

$\mathrm{K}_{\mathrm{zz}}$ is the vertical component of the hydraulic conductivity tensor $\left[\mathrm{LT}^{-1}\right]$

$W(x, y, z, t)$ is the volumetric flux per unit volume $\left[T^{-1}\right]$ and

b is the thickness of the hydraulic unit [L]. 
The computer code of Trescott (1975), later modified by Trescott and Larson (1976) and Torak (1982), used a finite-difference scheme to convert equation (1) into a numerical model for areally extensive aquifer systems. The system of finite-difference equations representing the study area is solved using the strongly implicit procedure (SIP).

\section{Finite-Difference Grid}

The aquifer system is represented by a grid having 59 east-west rows and 69 north-south columns (fig. 25). Cell dimensions range from 2,000 ft x 2,000 ft to $20,000 \mathrm{ft} \times 24,000 \mathrm{ft}$. The two outermost rows ( 1 and 59) and columns ( 1 and 69) in each layer form a no-flow boundary with transmissivity equal to zero. They are inserted around the border in each layer in the TrescottLarson finite-difference model for computational expediency.

The smallest cells are located in areas representing either actual or potential steep hydraulic-head gradients around major pumping centers in the vicinity of Minneapolis, St. Paul, and present-day river valleys. The greatest amounts of data also are available for these areas. Conversely, near the edge of the model, away from the centers of heavy use and areas of naturally steep hydraulic-head gradients, grid cells are large.

The size of model-grid nodes determines the resolution of model results. As a result, scenarios that can be modeled and successfully interpreted (1) provide general insights to the hydrologic response of the ground-water system to both natural and man-made stresses; and (2) need to be interpreted in terms of the regional ground-water-flow system as opposed to specific responses of local flow systems to local hydrologic stress.

\section{Layering Scheme}

The aquifer system was divided into ten layers for this study (fig. 26). The top layer (layer 10) represents drift near the center of the modeled area (fig. 27). Al1 other layers represent both drift and bedrock. The layers represent, in order of increasing depth below land surface, the St. Peter (1ayer 9), Prairie du Chien-Jordan (layer 8), Ironton-Galesville (layer 7), and Mount Simon-Hinckley (layer 1) aquifers. The Eau Claire confining unit is represented by model layers 2-6. Implicitly represented between the layers, in order of increasing depth below land surface are the Decorah-PlattevilleGlenwood (9-10), lower St. Peter (8-9), St. Lawrence-Franconia (7-8), and Eau Claire (6-7 through 1-2) confining units. Where the hydrogeologic units (either bedrock or drift or both) are absent in each layer, no-flow cells with transmissivity equal to zero were inserted. The Eau Claire confining unit was explicitly represented as multiple layers so that accurate flow from storage in the confining unit could be simulated at a later date under time-dependent (transient) conditions. Figure 28 shows the distribution of bedrock and drift hydrogeologic units in the different model layers. 
COLUMN



Figure 25.--Finite-difference grid used in model analysis. 


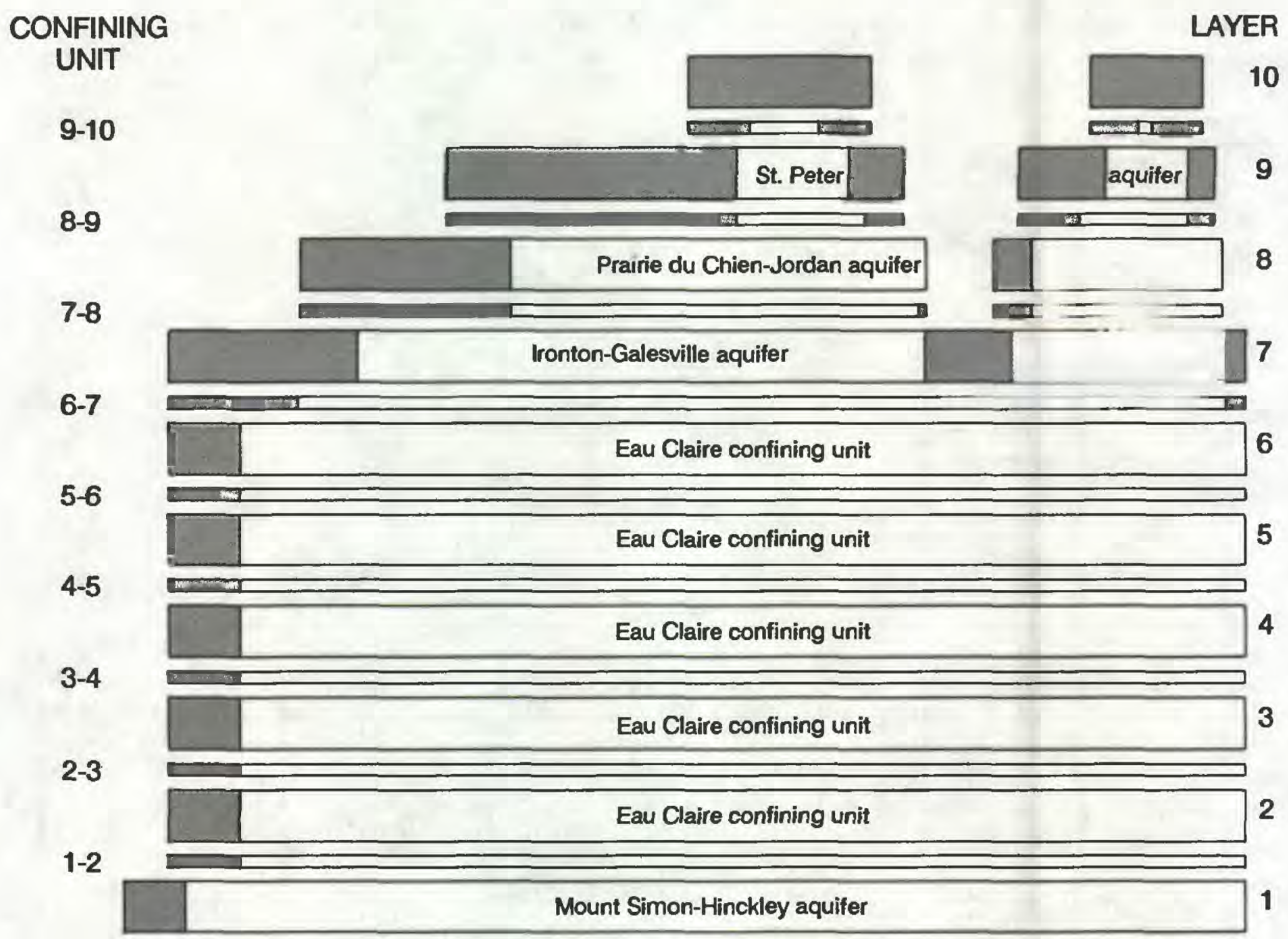

\section{EXPLANATION}

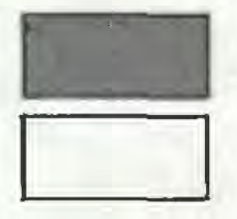

Drift (bedrock missing)

Bedrock

Confining Unit

9-10

8-9

7-8

Hydrogeologic Units

Drift and Decorah-Platteville-Glenwood confining unit

Drift and lower St. Peter confining unit

Drift and St. Lawrence-Franconia confining unit

$1-2,2-3,3-4,4-5,5-6,6-7$ Drift and Eau Claire confining unit

Figure 26--Generalized layering scheme for model. 


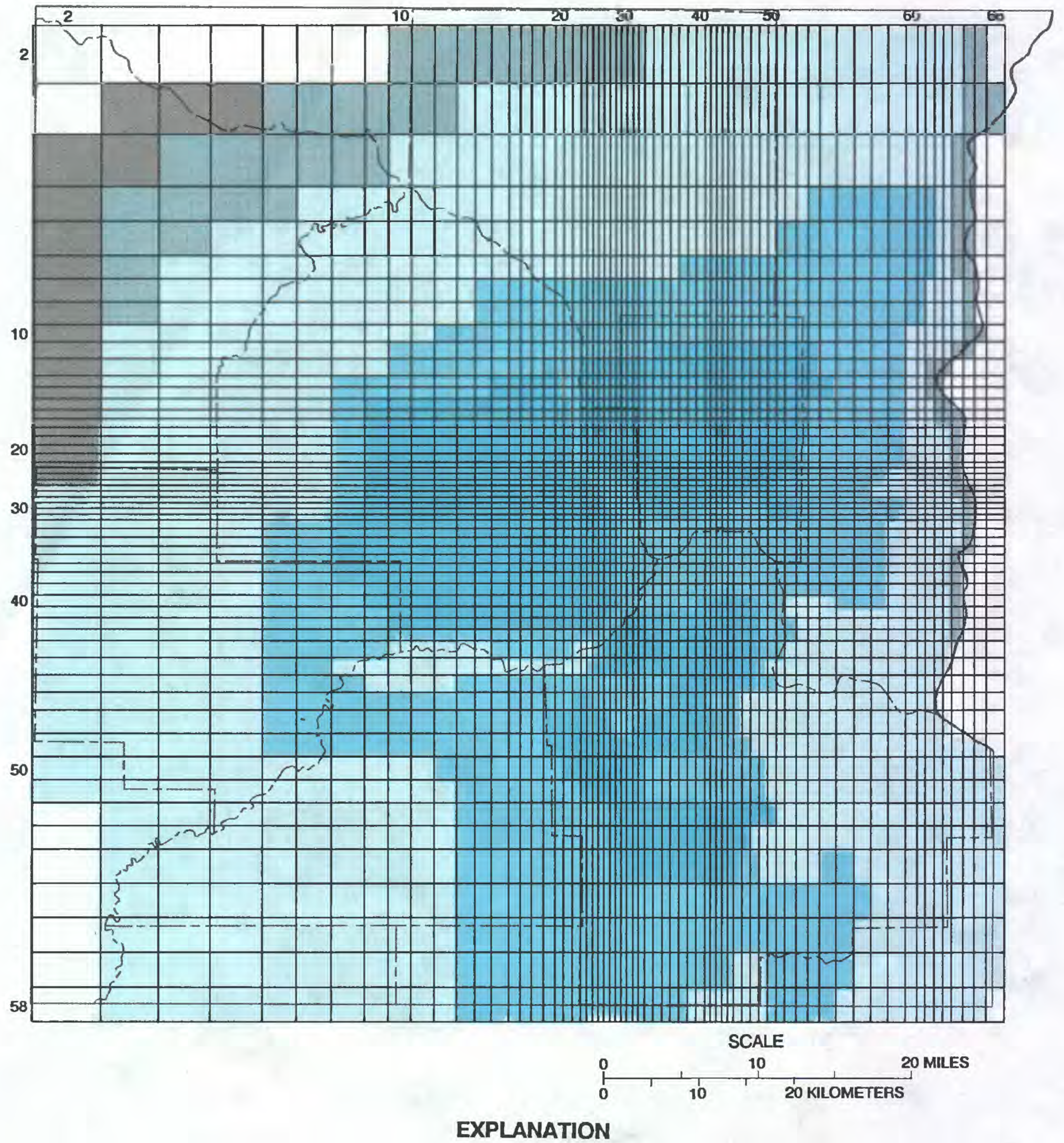

UPPER MOST MODEL LAYER

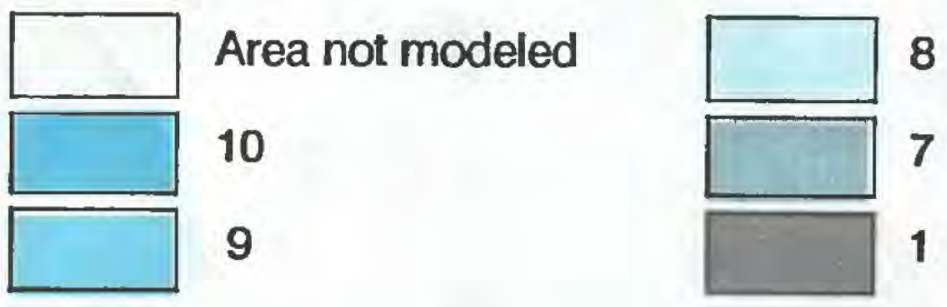

Figure 27.-Uppermost model layer at each cell. 


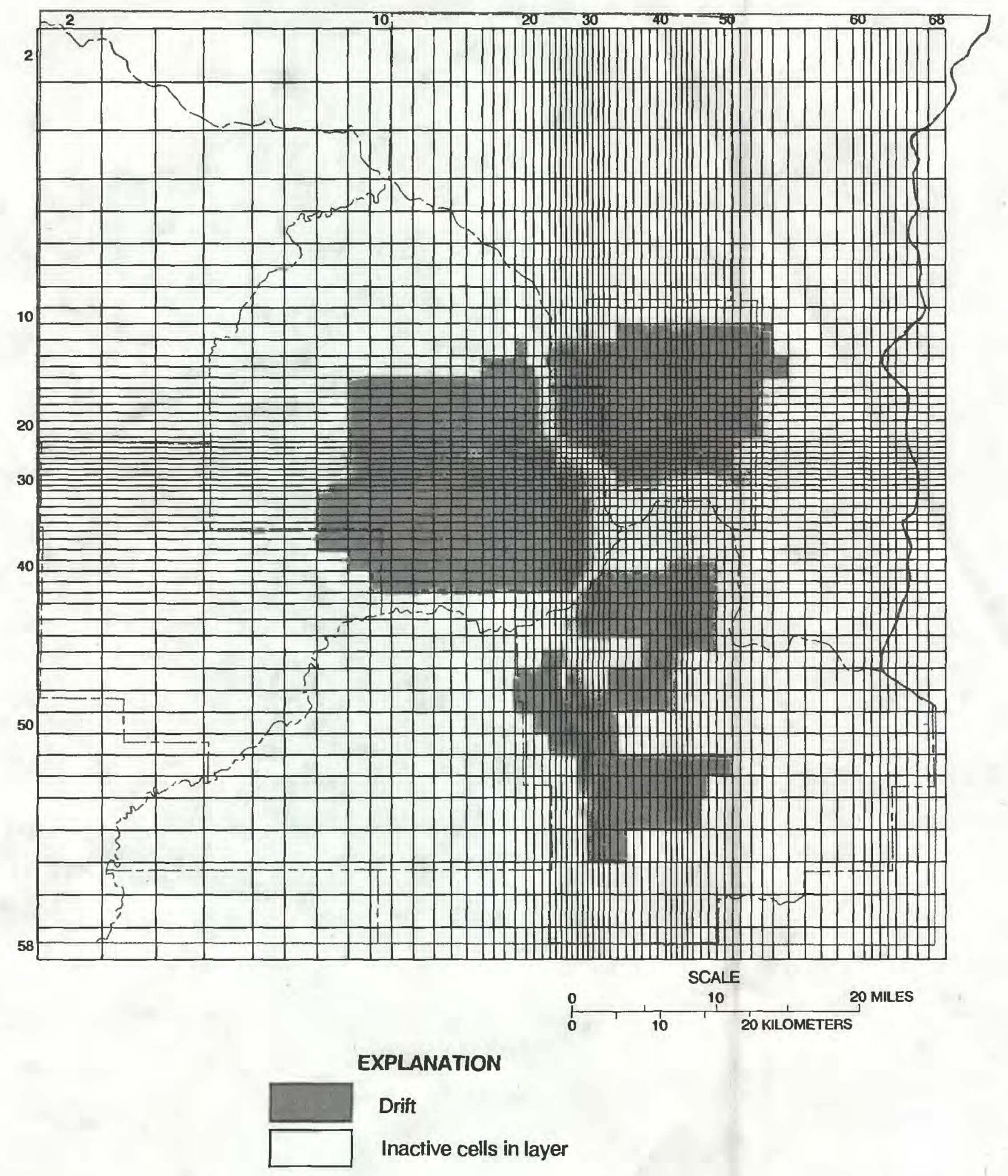

Figure 28a.--Distribution of bedrock, drift, and drift-filled bedrock valleys in model layer 10 (drift aquifer). 


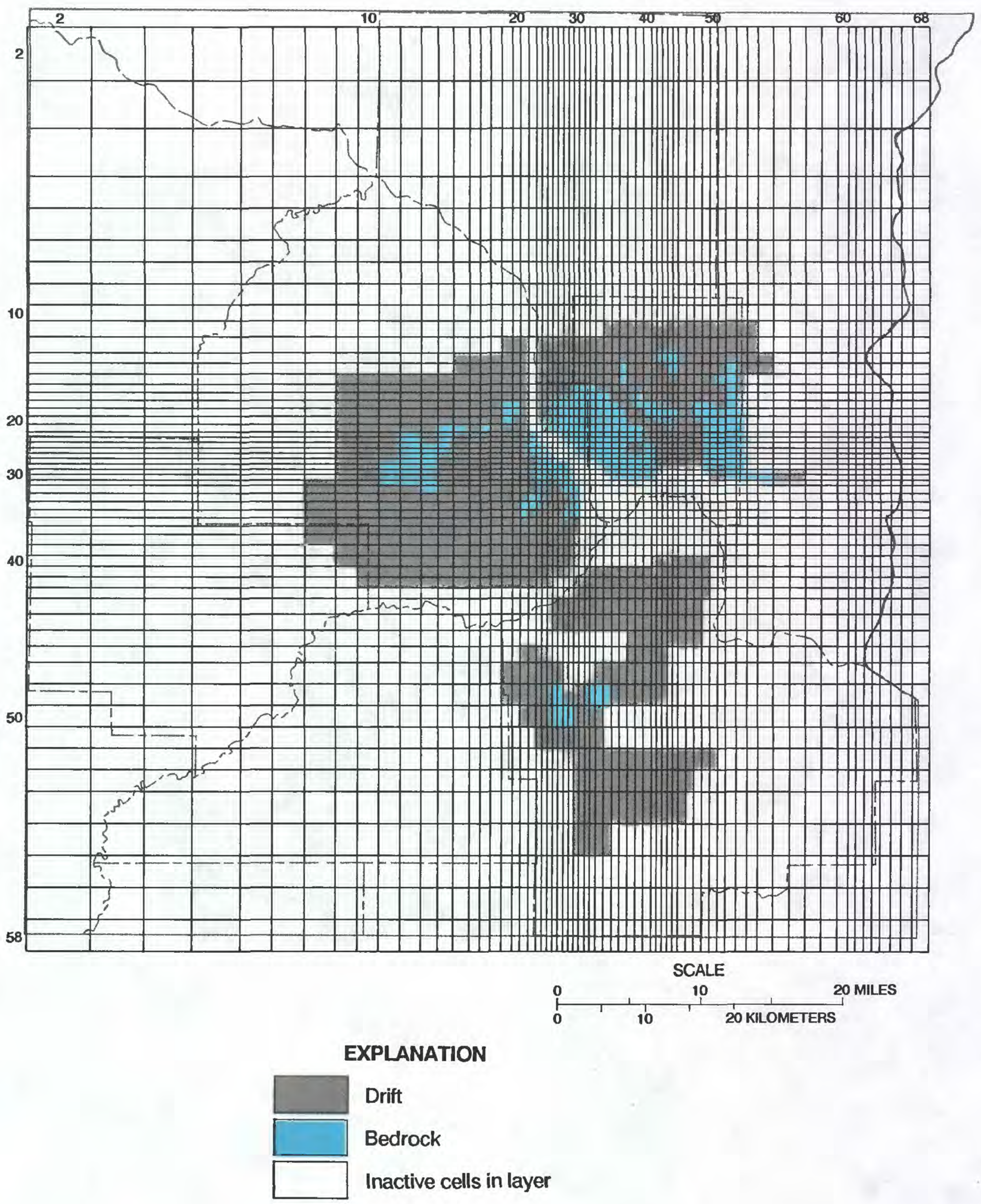

Figure 28b.--Distribution of bedrock, drift, and drift-filled bedrock valleys in confining unit 9-10 (Decorah-Platteville-Glenwood confining unit). 


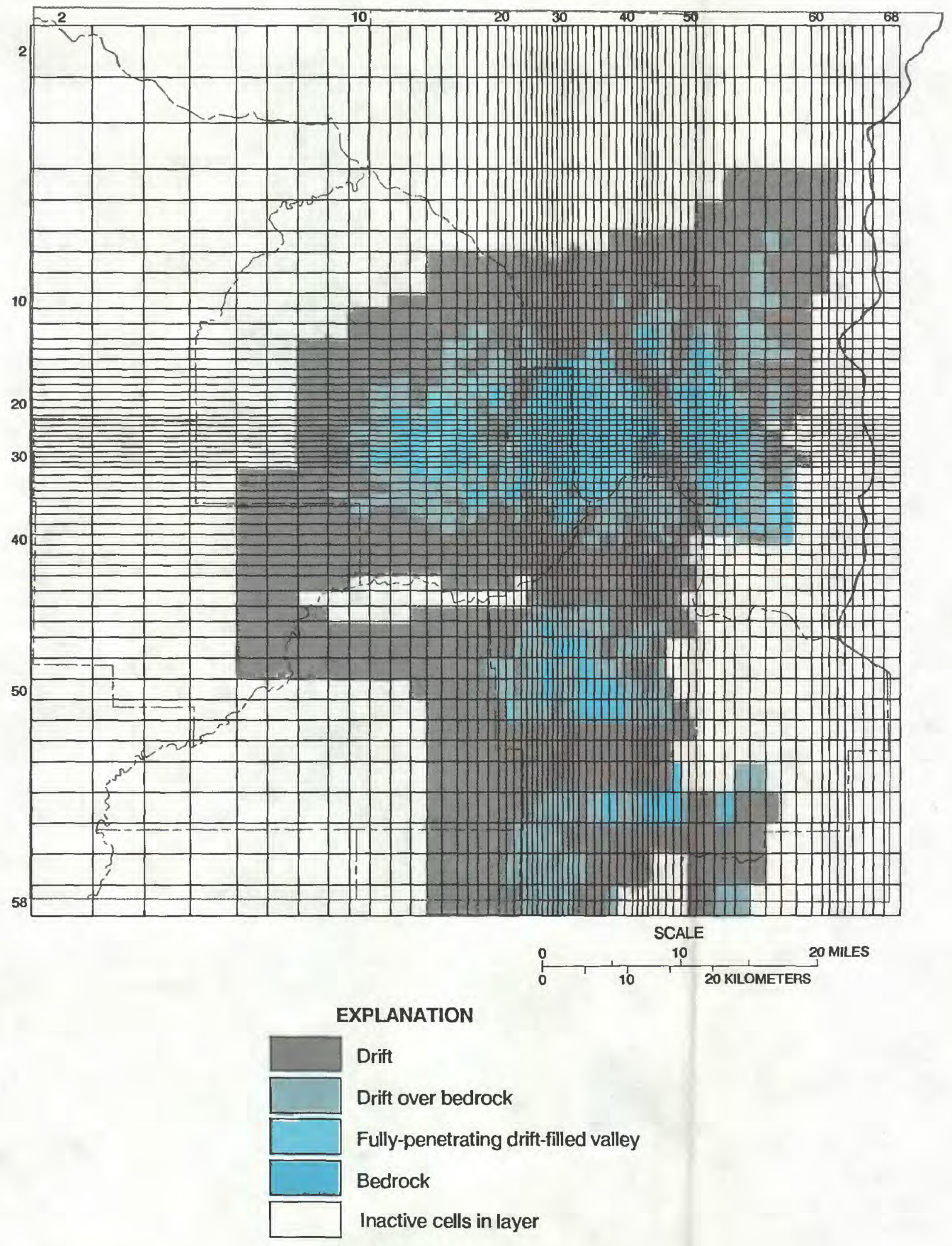

Figure 28c.--Distribution of bedrock, drift, and drift-filled bedrock valleys in model layer 9 (St. Peter aquifer). 


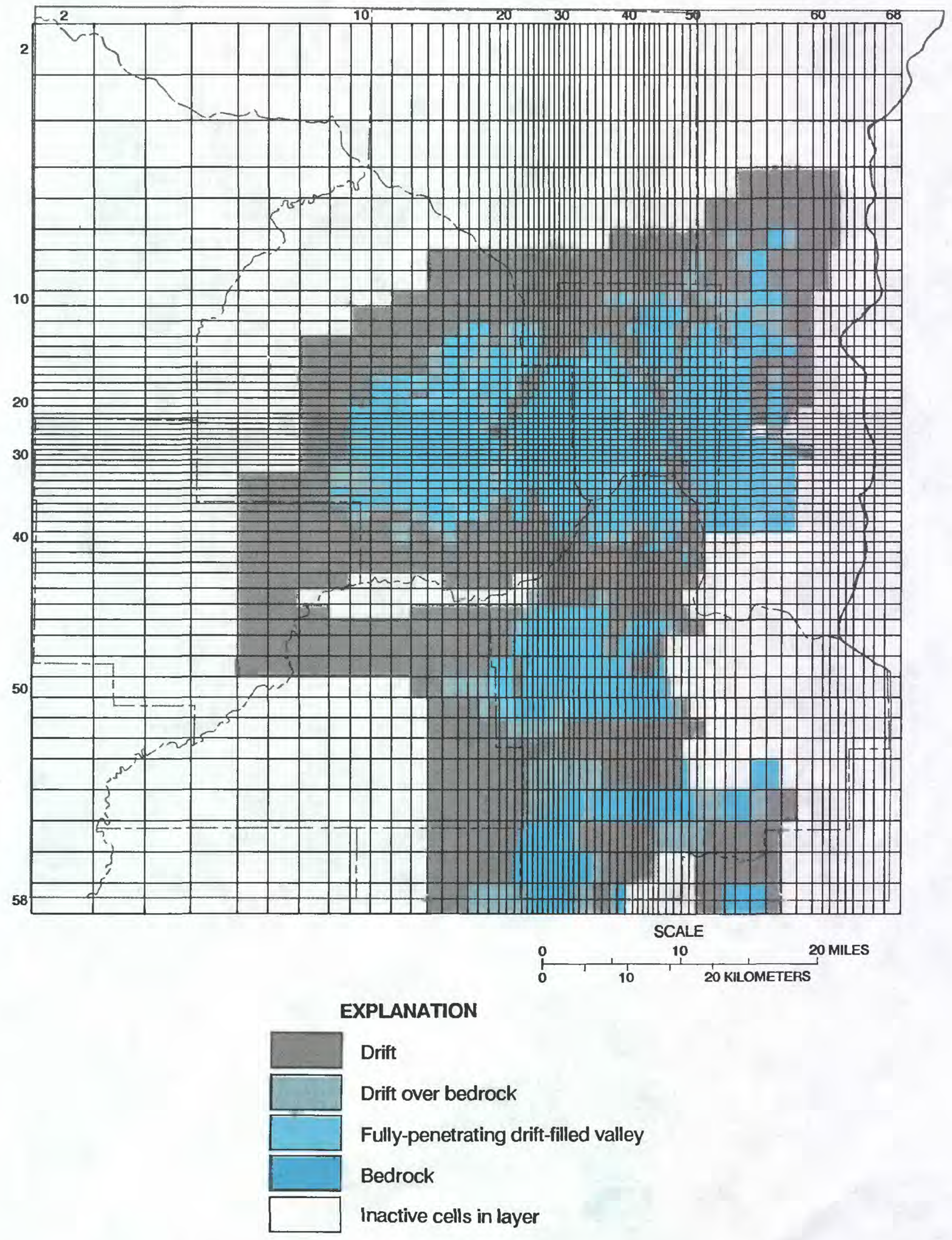

Figure 28d.--Distribution of bedrock, drift, and drift-filled bedrock valleys in confining unit 8-9 (lower St. Peter confining unit). 


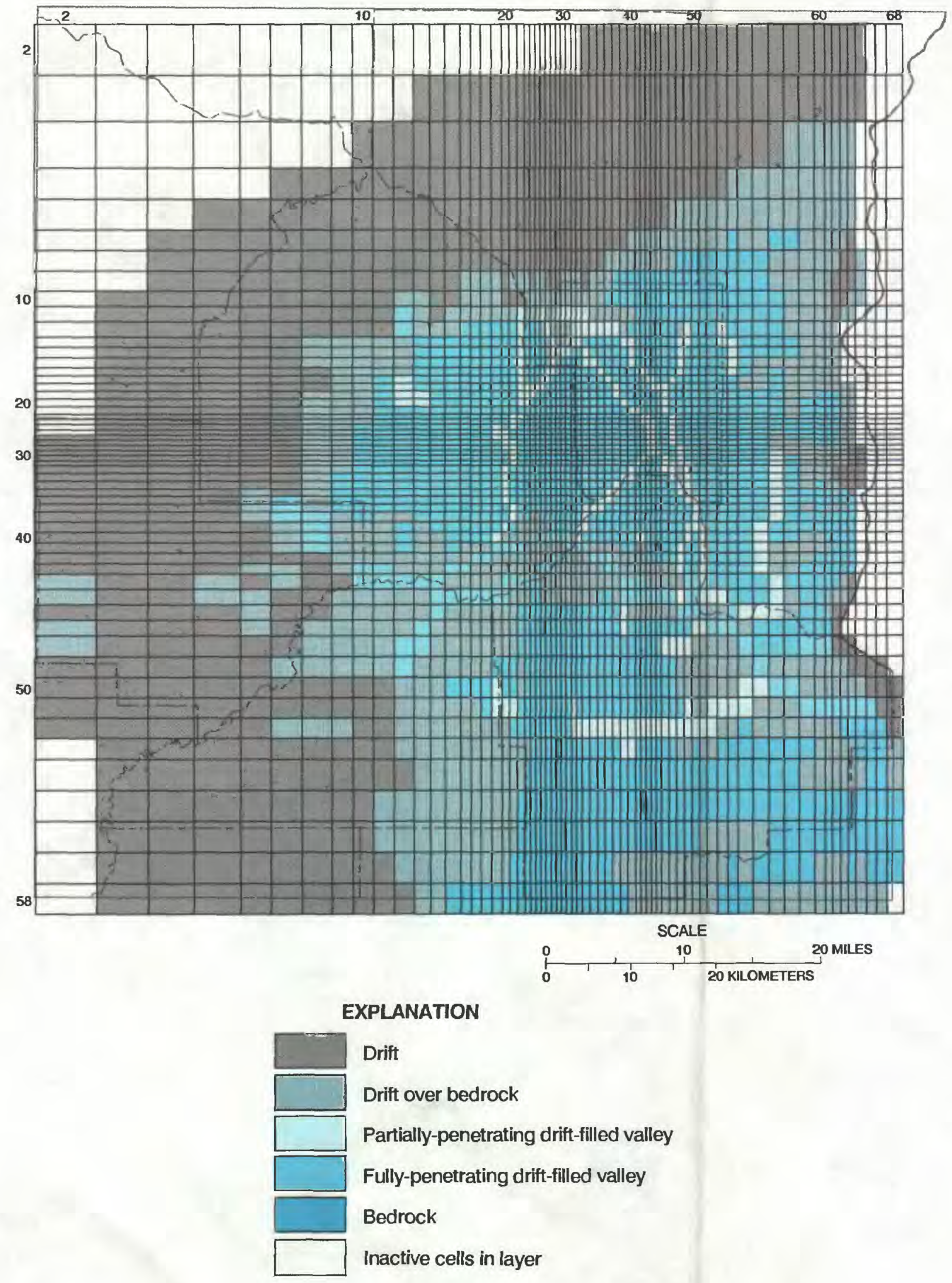

Figure 28e.--Distribution of bedrock, drift, and drift-filled bedrock valleys in model layer 8 (Prairie du Chien-Jordan aquifer). 


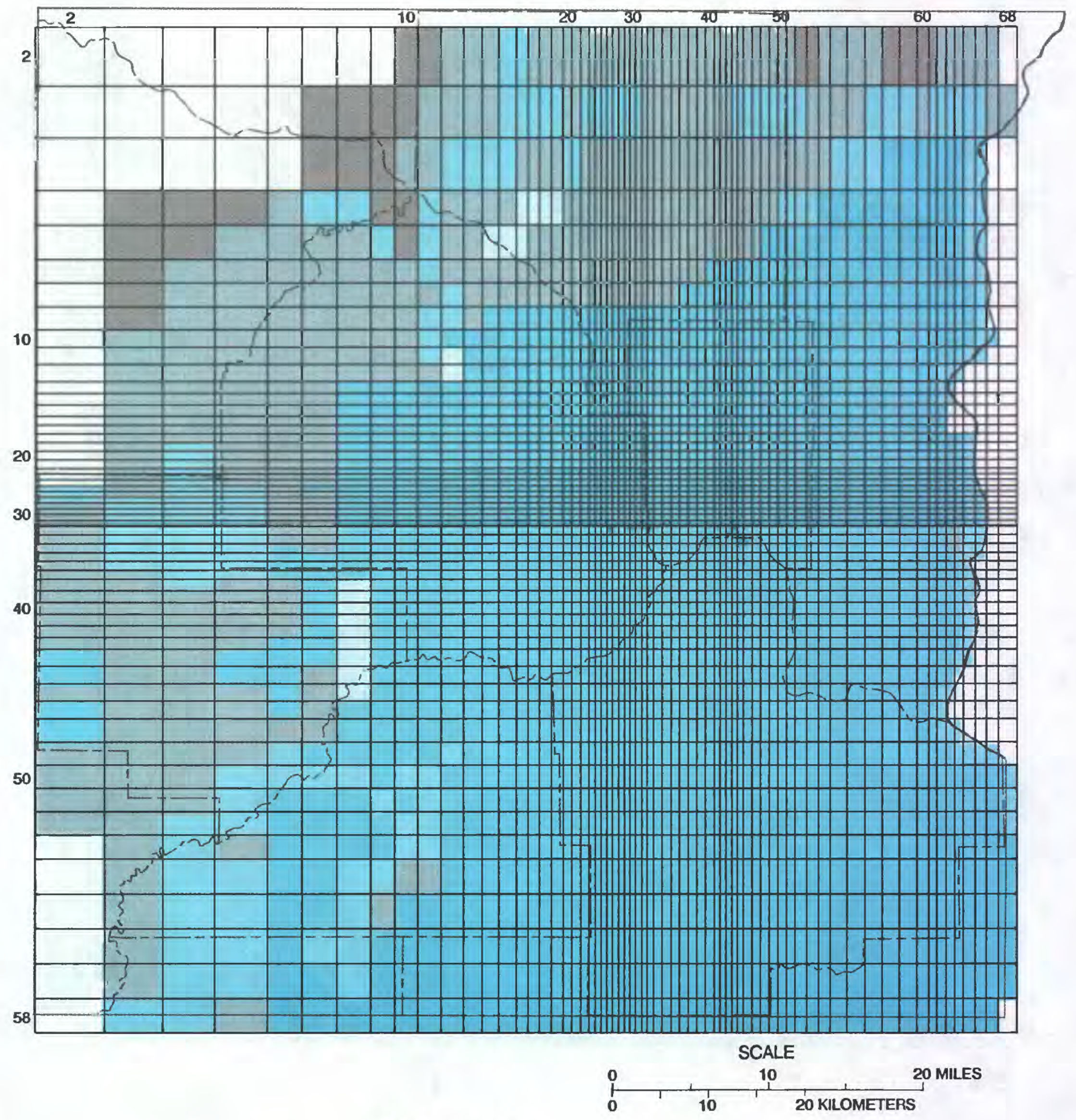

EXPLANATION

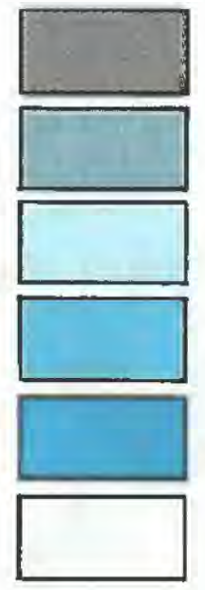

Drift

Drift over bedrock

Partially-penetrating drift-filled valley

Fully-penetrating drift-filled valley

Bedrock

Inactive cells in layer

Figure 28f.--Distribution of bedrock, drift, and drift-filled bedrock valleys in confining unit 7-8 (St. Lawrence-Franconia confining unit). 


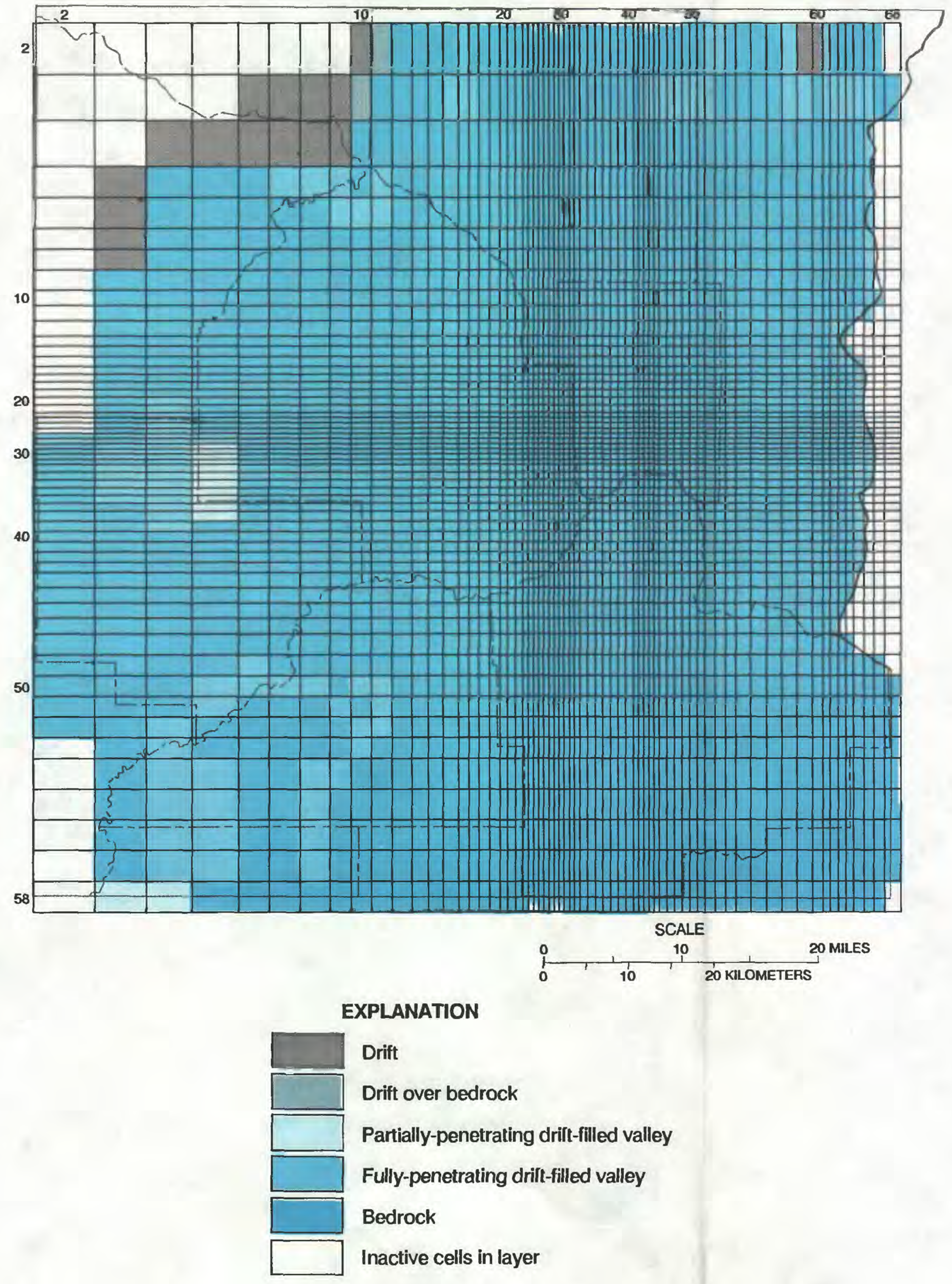

Figure 28g.--Distribution of bedrock, drift, and drift-filled bedrock valleys in model layer 7 (Ironton-Galesville aquifer). 


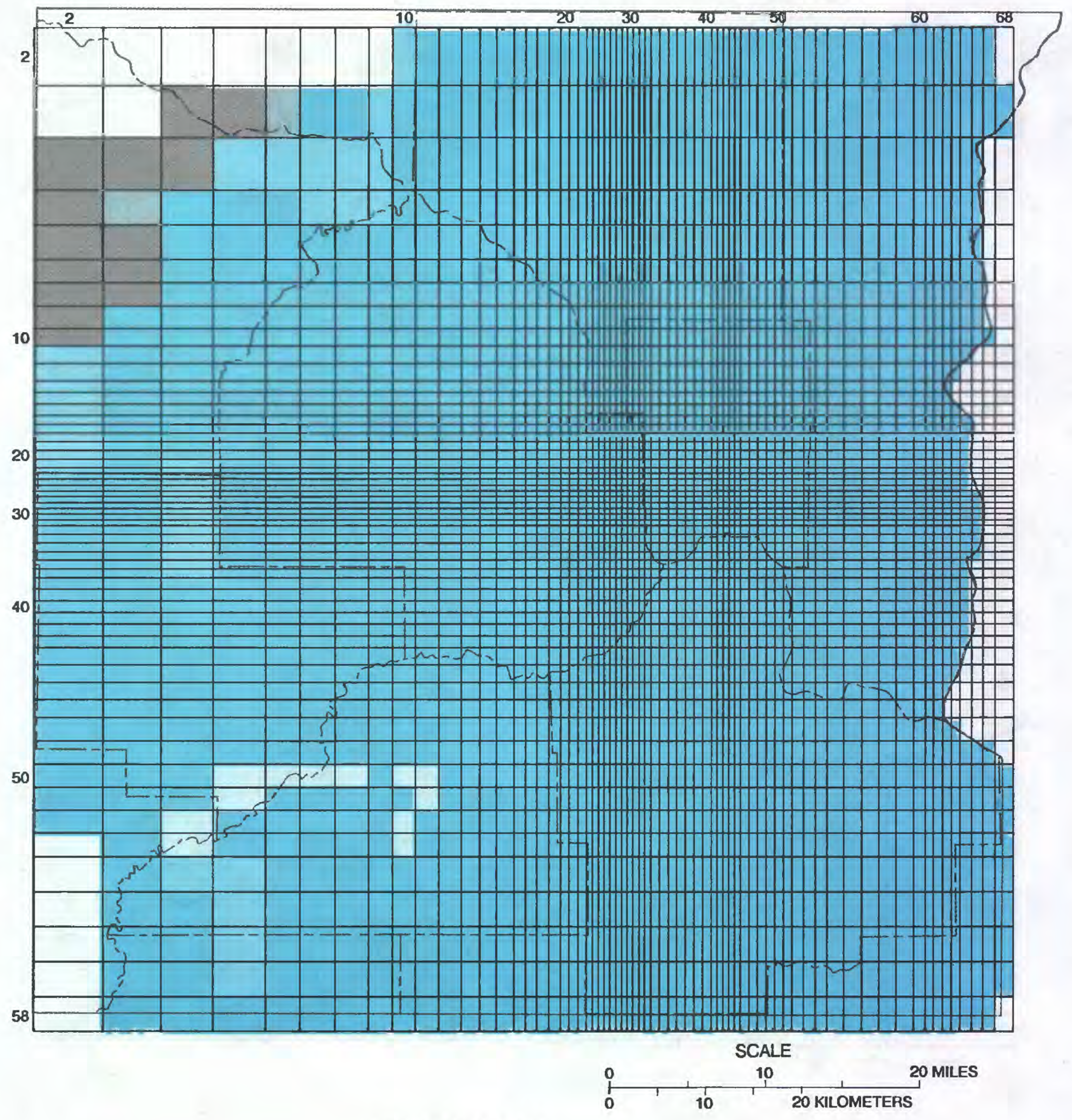

EXPLANATION

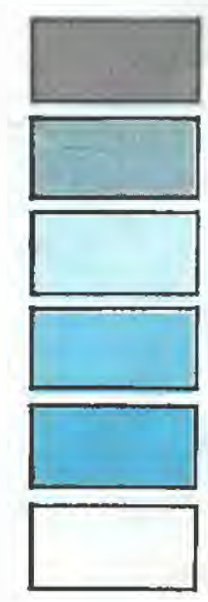

Drift

Drift over bedrock

Partially-penetrating drift-filled valley

Fully-penetrating drift-filled valley

Bedrock

Inactive cells in layer

Figure 28h.--Distributionof bedrock, drift, and drift-filled bedrock valleys in model layers 2 through 6 and confining units 1-2 through 6-7 (Eau Claire confining unit). 


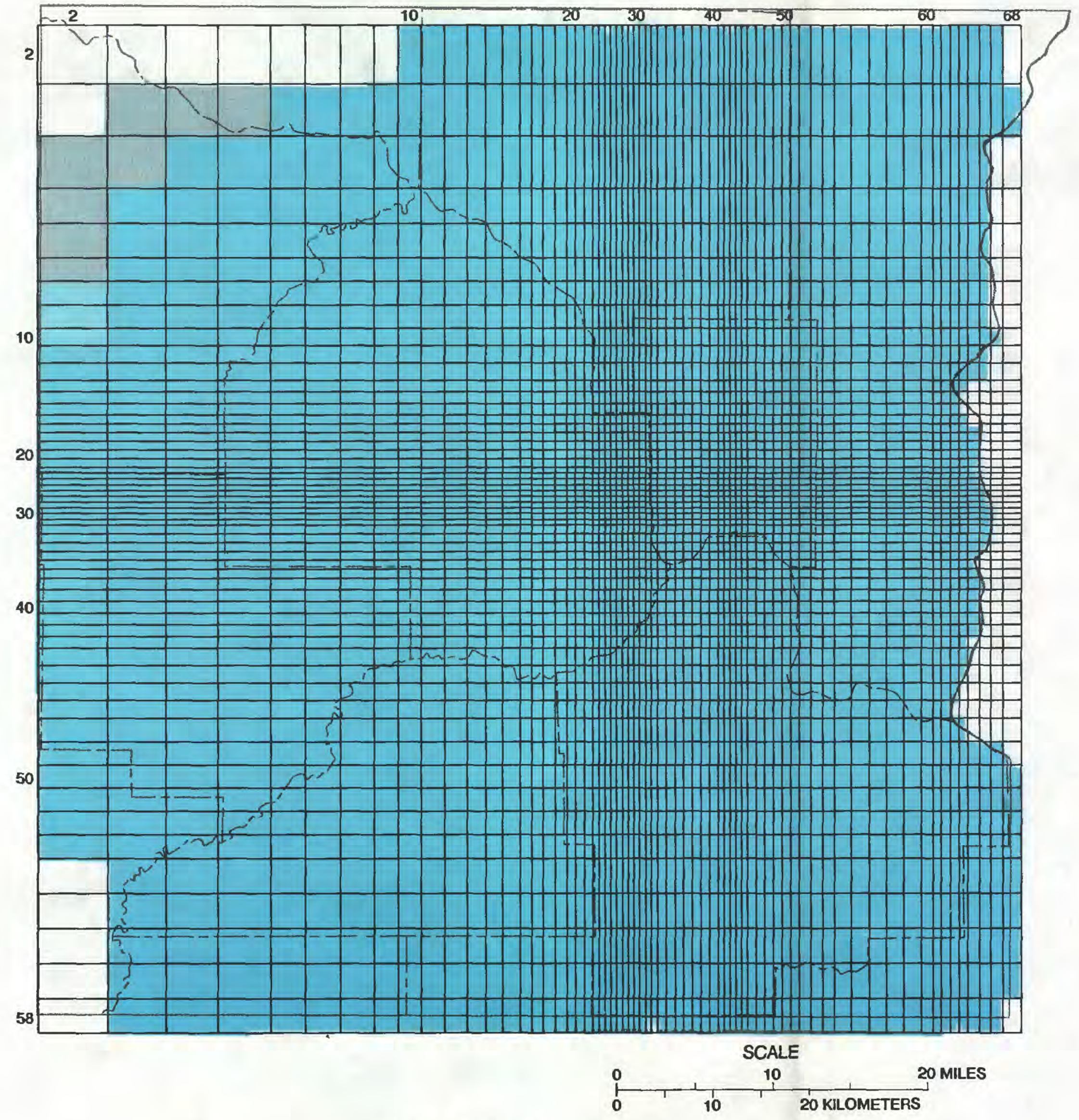

EXPLANATION

\begin{tabular}{|c|}
\hline Drift over bedrock \\
\hline Fully-penetrating drift-filled valley \\
\hline Bedrock \\
\hline Inactive cells in layer \\
\hline
\end{tabular}

Figure 28i.-Distribution of bedrock, drift, and drift-filled bedrock valleys in model layer 1 (Mount Simon-Hinckley aquifer). 
Model cells representing either solely bedrock or solely drift were assigned transmissivity values calculated from the product of average horizontal hydraulic conductivity and thickness. In many areas, bedrock hydrogeologic units are either partially or completely cut by pre-glacial valleys and the valleys are filled with drift. Model cells at these locations represent both bedrock and drift. For these, transmissivity was calculated from the attitude of the valley and the relative percentages of bedrock and drift in the cell represented. This step was taken to represent and model the effects of driftfilled, bedrock valleys on ground-water flow. Vertical flow in the aquifer system was simulated by allowing leakage through semiconfining units. A leakage coefficient was calculated for each model node by dividing the vertical hydraulic conductivity of the semiconfining unit by its thickness. In places where model-grid cells represent both drift and bedrock, the calculations of leakage coefficients took into account the relative percentage of bedrock and drift in the cell. The calculations of transmissivity and leakage coefficients used in this model are explained in detail in Appendix A.

\section{Discretization of Data}

Discretization represents data from either map form or point values to values expressed in terms of cell locations. Each value represents a property that is constant within that cell. Therefore, changes in hydrogeologic properties in digital models are jumps in values, not smooth changes. As a result, model results cannot be interpreted over areas which are smaller than the area represented by individual cells, which differ in size over the modeled area. Discretization involves interpolation when data points are few and averaging when data are available in great detail. Use of interpolation and averaging are based on information about hydrogeologic characteristics of the aquifer system, overall behavior of the flow system, and current understanding of geologic processes. In natural systems, hydrogeologic characteristics generally change smoothly and continuously. Many hydrogeologic characteristics of aquifers and semiconfining units can be described by mean-log values because the characteristics have a log-normal distribution (Neuman, 1982). In areas represented by larger cells, extreme, but local, variations in bedrock and drift thickness were averaged. Consequently, representation of small drift-filled bedrock valleys tends to be poor.

Model input for each cell includes transmissivity and leakage-coefficient values for the adjacent semiconfining units. Values for each cell were calculated from thickness and hydraulic-conductivity values rather than data directly from aquifer tests because thickness data were readily available, most accurate, and had the greatest areal distribution. Average thickness for each cell was visually estimated in 40 -ft-thick intervals by superimposing the model grid over a thickness map for each unit. Other characteristics affecting the transmissivity and leakage-coefficient values that were digitized include (1) size and direction of drift-filled bedrock valleys; (2) unsaturated thickness of the Prairie du Chien-Jordan and St. Peter aquifers; and (3) drift zonation. 


\section{Boundary Conditions of Mode1}

In order for the numerical model to calculate heads, efther hydraulic head or flux must be given at the fixed hydraulic boundarles of the model. Hydraulic boundarles are specified at the edge of the model (external boundary conditions) or within the area represented by the model (Internal boundary conditions). External boundary conditions represent lateral extent or head and flow conditions of each aquifer at the edge of the model. The top and bottom external boundaries are the water table and the base of the aquifer system, respectively. Internal boundary conditions represent leaky rivers, springs and seepage faces, and heads along rivers and at lakes. Each type of boundary condition is discussed as it relates to the real aquifer system. Figure 29 presents the boundary conditions used in each model layer. The uppermost model layer at each cell (fig. 26) recelves recharge.

\section{No-Flow Boundaries}

No-flow boundaries were used to (1) separate active and inactive cells within the model and (2) terminate a layer at the edge of the model. In the first case, the boundary is placed where the aquifer or confining unit ends within the model (fIg. 29). In the second case, elther the edge of the mode1 approximates a flow divide or is affected by an overlying boundary condition or both. The northern boundary of layer 1 , representing the Mount SimonHinckley aquifer (fig. 29e), typifies the second type of boundary. Hydrologic and stratigraphic evidence presented earlier suggests that the Mount SimonHinckley aquifer, Eau Clalre confining unit, and Ironton-Galesville aquifer are possibly indistinguishable in that area. Consequently, the Mount SimonHinckley aquifer receives recharge directly from infiltration of precipitation or by leakage from the overlying units. This flow to the aquifer was simulated with a high vertical-leakage coefficlent between layers 1 and 7 .

\section{Head-Dependent Flux Boundarles}

A head-dependent flux boundary is used along the southern edge of model layer 1 ( $\mathrm{fig}$. 29e). This boundary consists of a water source outside the modeled area that supplies water to cells along the inside edge of the area represented by the model. Water is supplied to the boundary at a rate proportional to the head difference between the source and the head calculated at the center of the inside cell and the hydraulic conductivity of the aquifer material between the locations. The source of water was located about $17 \mathrm{mi}$ south of the model boundary at the approximate flow divide in the Mount SimonHinckley aquifer (Delin and Woodward, 1985). One difficulty with establishing and verifying this model boundary was the virtual absence of head and hydrau1ic data for the Mount Simon-Hinckley aquifer both in the southern part of the modeled area and to the south of the modeled area. Consequently, flow across this boundary was taken as a variable and changed during model calibration by adjusting the hydraulic conductivity. 


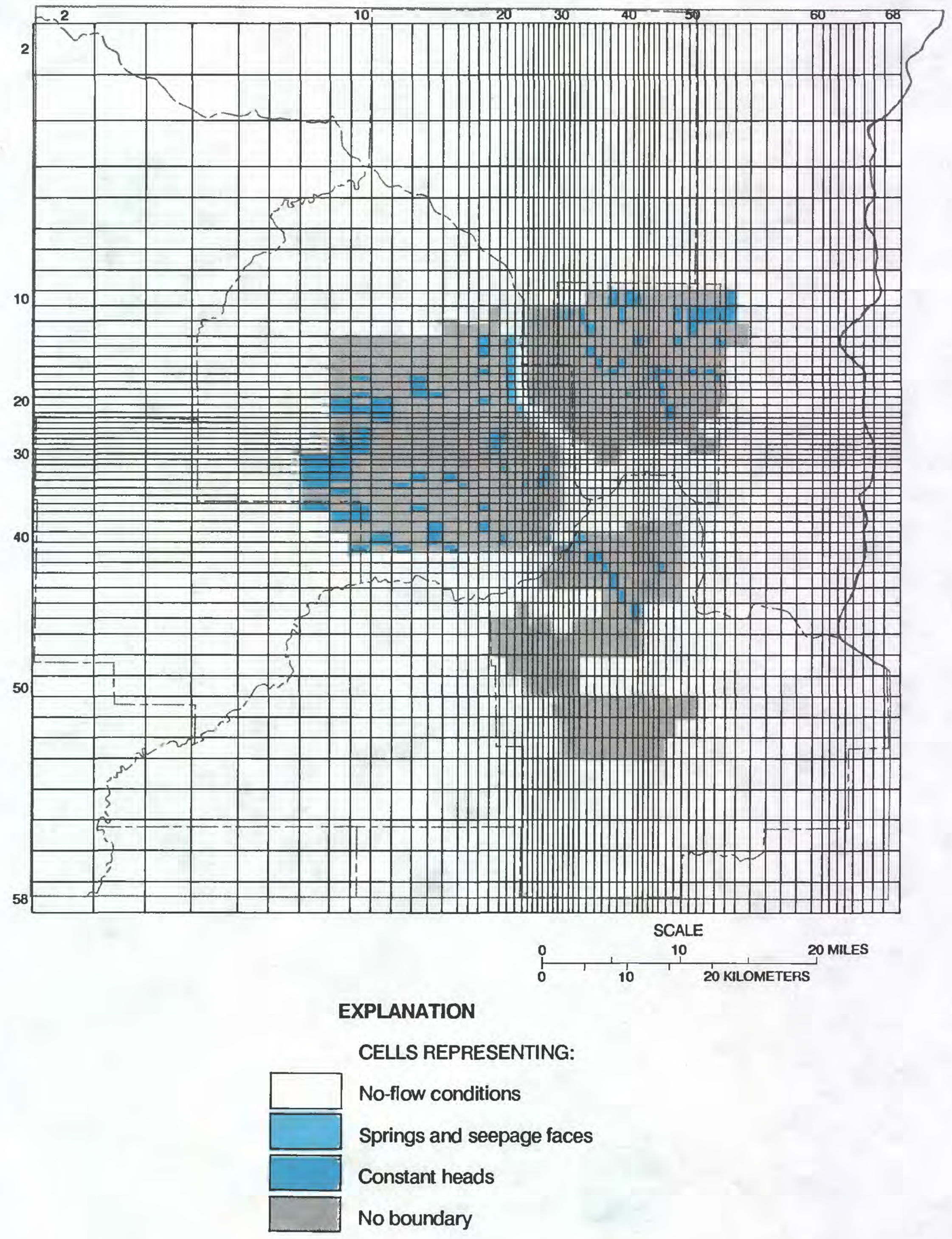

Figure 29a.-Boundary conditions in model layer 10 (drift aquifer). 


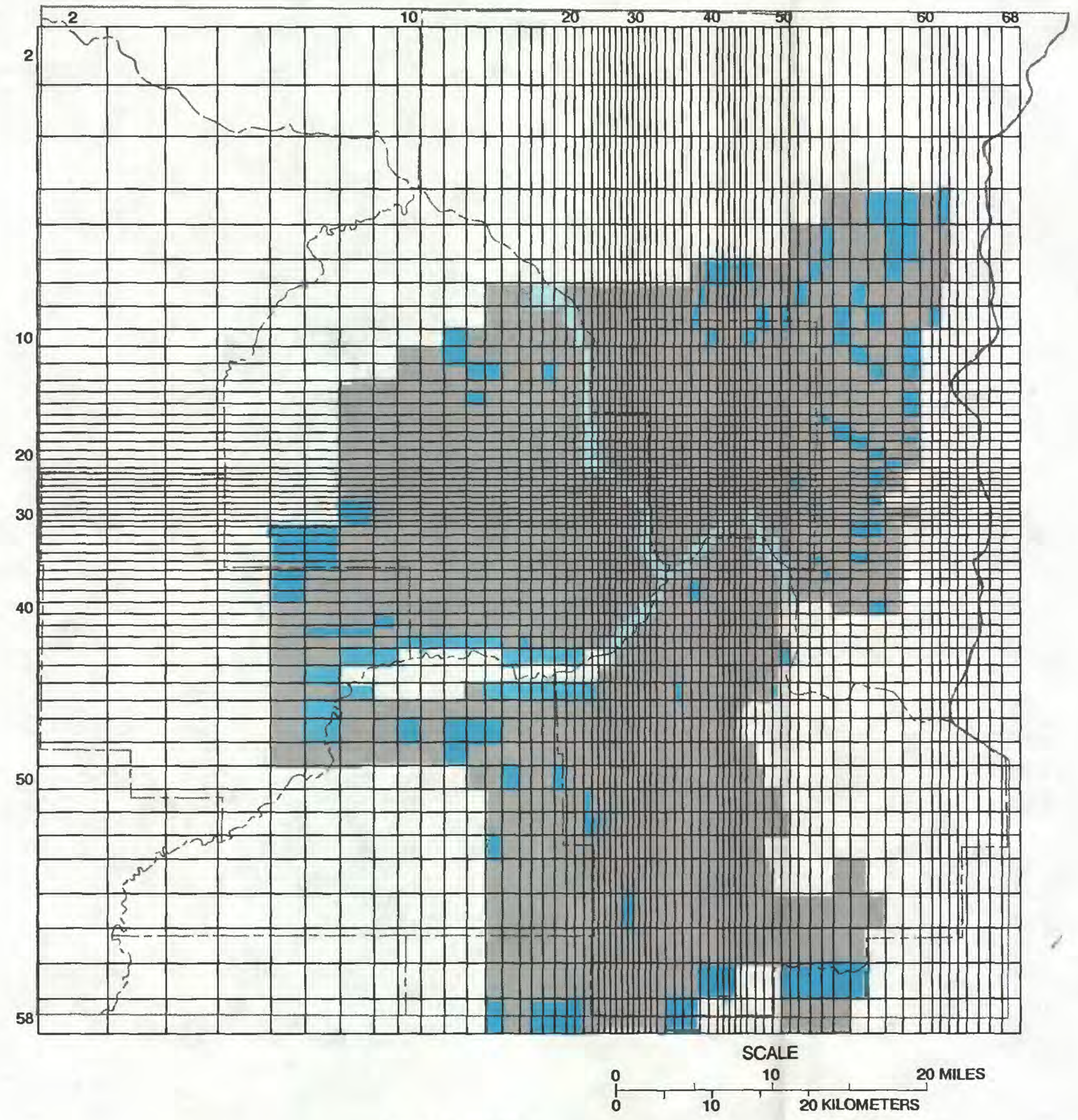

EXPLANATION

CELLS REPRESENTING:

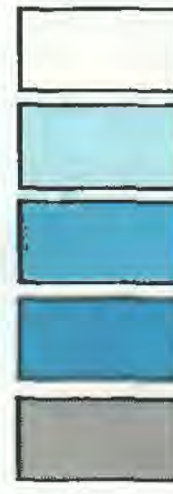

No-flow conditions

Leaky rivers

Springs and seepage faces

Constant heads

No boundary

Figure 29b.-Boundary conditions in model layer 9 (St. Peter aquifer). 


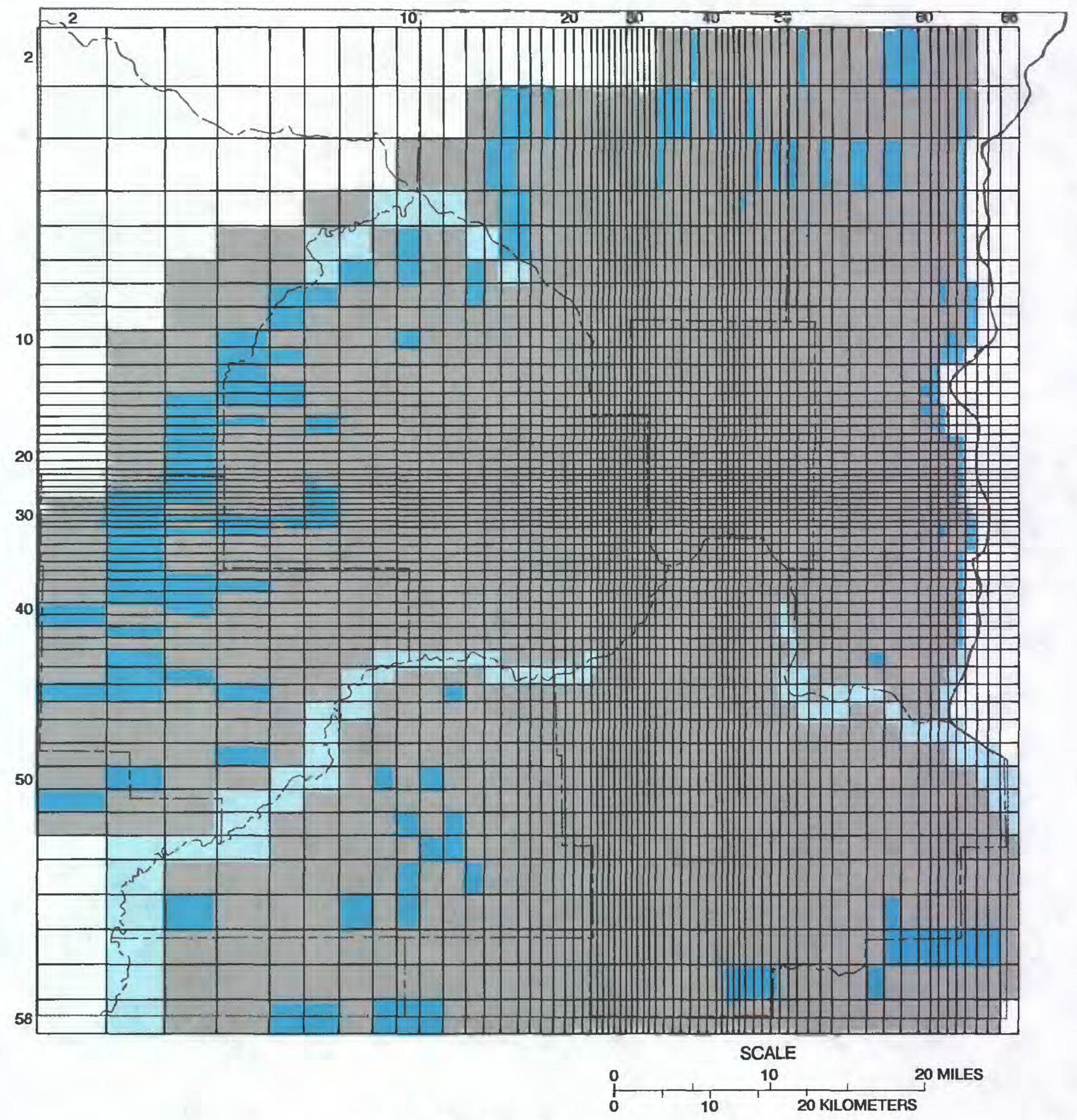

EXPLANATION

CELLS REPRESENTING:

\begin{tabular}{|c|}
\hline No-flow conditions \\
\hline Leaky rivers \\
\hline Springs and seepage faces \\
\hline Constant heads \\
\hline No boundary \\
\hline
\end{tabular}

Figure 29c.--Boundary conditions in model layer 8 (Prairie du Chien-Jordan aquifer). 


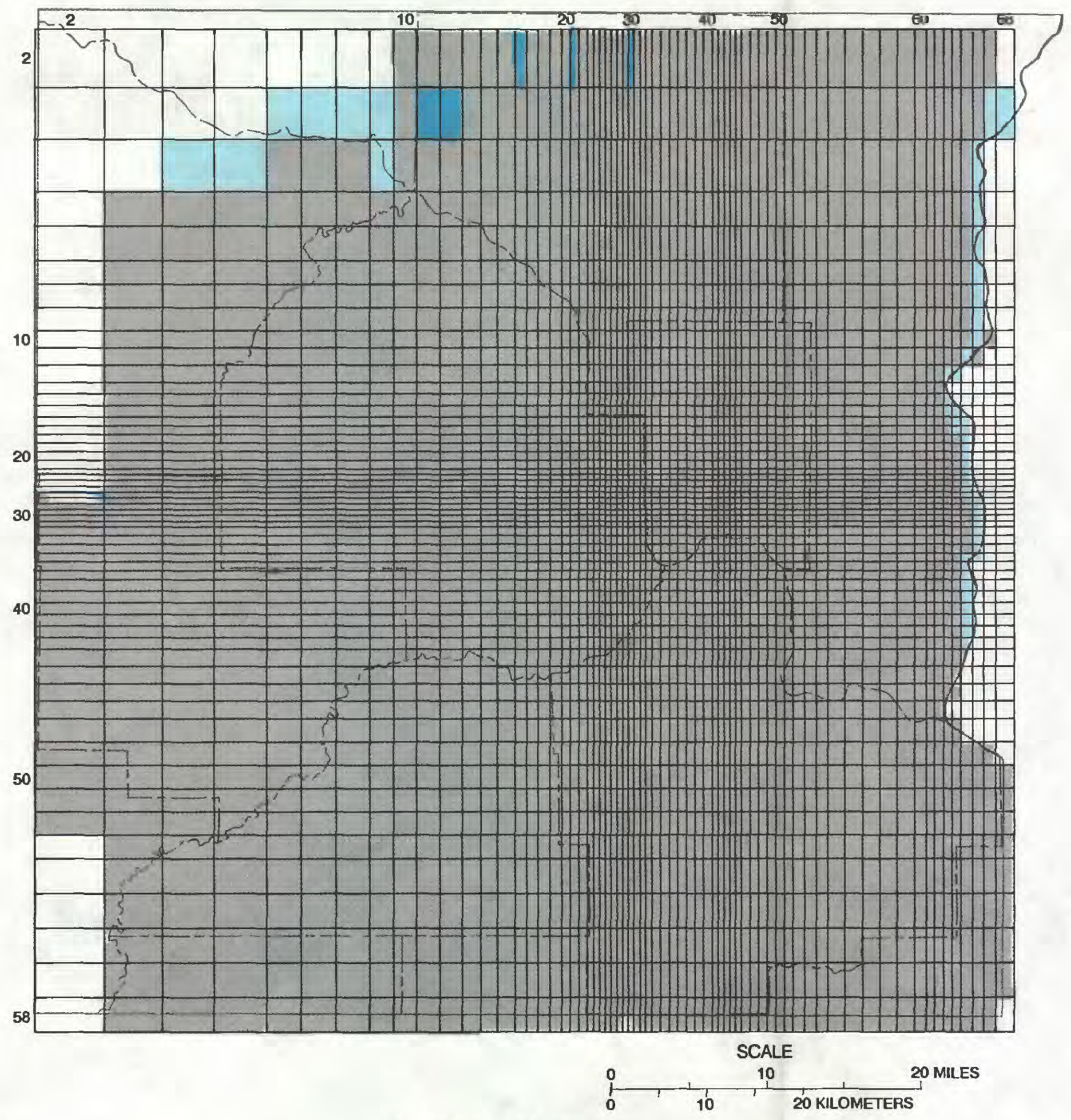

EXPLANATION

CELLS REPRESENTING:

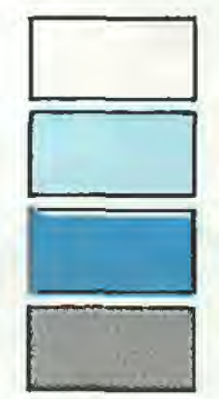

No-flow conditions

Leaky rivers

Constant heads

No boundary

Figure 29d.-Boundary conditions in model layer 7 (Ironton-Galesville aquifer). 


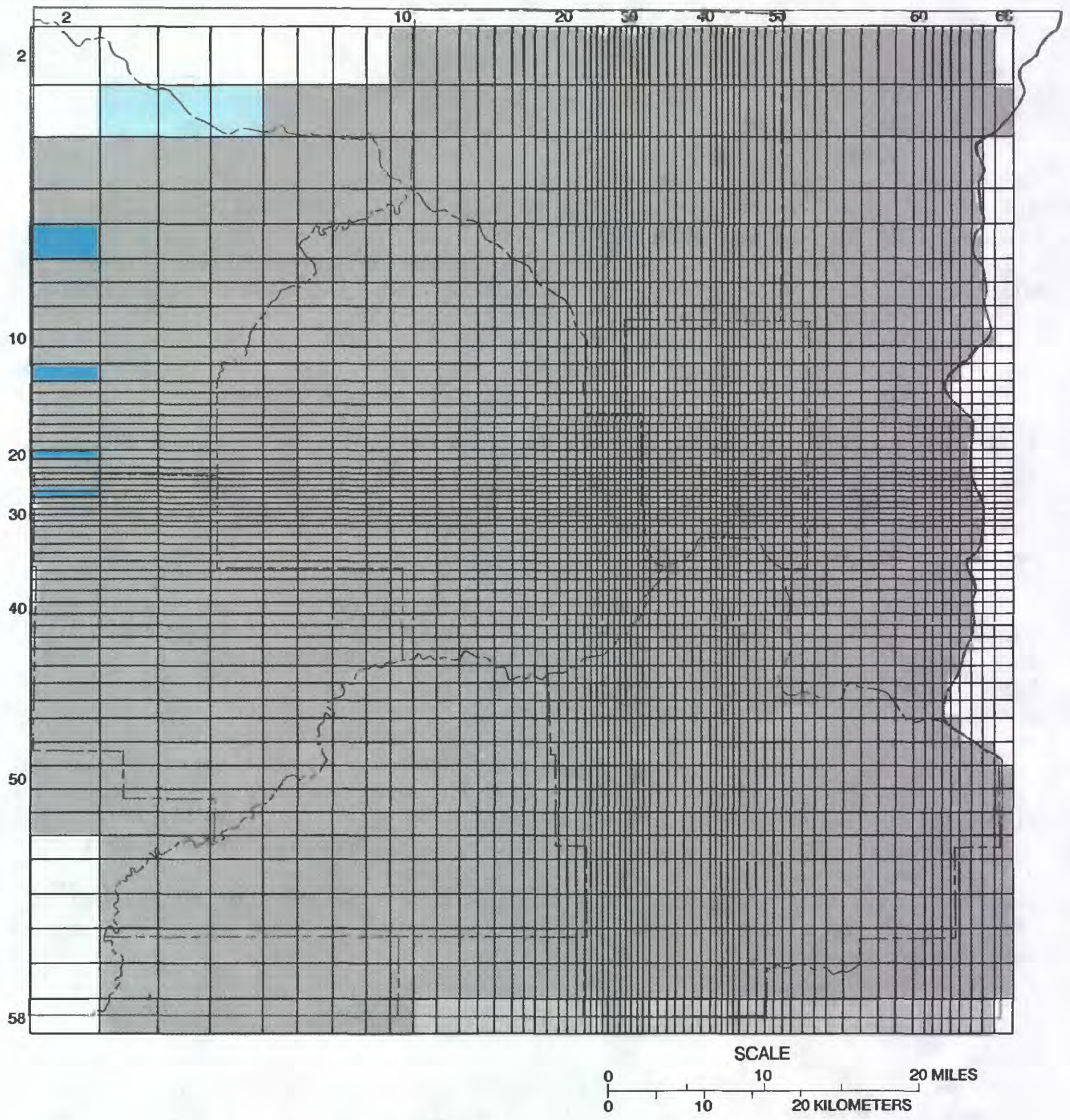

EXPLANATION

CELLS REPRESENTING:

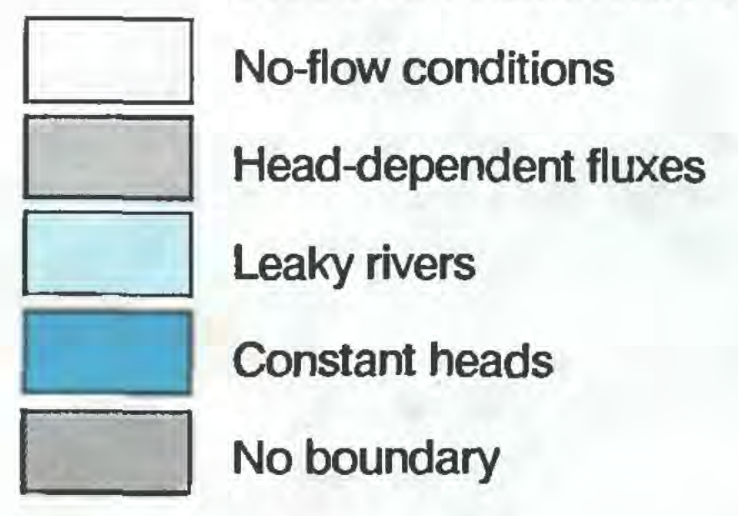

Figure 29e.-Boundary conditions in model layer 1 (Mount Simon-Hinckley aquifer). 
The channels of the Mississippi, Minnesota, and St. Croix Rivers are important discharge areas for the aquifer system (fig. 29). Water from the Mississippi River in the vicinity of Minneapolis also naturally infiltrates into the aquifer system. The volume of water gained or lost by the rivers is a function of the difference between river stage and aquifer head. In the model, average river stage was estimated from USGS 7 1/2-minute topographic maps. The streambed leakage coefficient is based on the vertical hydraulic conductivity of streambed material. When aquifer head exceeds river stage, the river gains water from the aquifer. Conversely, when river stage exceeds aquifer head, the river loses water to the aquifer. Infiltration of river water to the aquifer increases from zero when the calculated aquifer head equals river stage to a maximum when the calculated aquifer head equals the altitude of the river bottom. If the calculated aquifer head is lower than the river bottom altitude, infiltration of river water is set equal to the amount of water that would be available if the calculated aquifer head is equal to the river-bottom altitude.

Selection of a value for hydraulic conductivity of the streambed was based on the observation that all the major river valleys in the study area are filled with alluvium or reworked glacial drift (Matsch, 1983; Kehew and Lord, 1986). In the model, streambed thickness was taken as the thickness of drift and alluvium between the top of the cell over which the river flowed and the center of that cell. Implicit in this definition of streambed thickness is that leakage between the river and the underlying aquifer is controlled by the river bottom. This contradicts actual observations, because leakage into rivers often occurs through areas adjacent to river banks. Consequently, the coefficient originally calculated for streambed leakage was treated as a variable and was adjusted during model calibration. However, because of regional scale of the model and the complex nature and extremely variable thickness of the streambed material, the calibrated value of streambed leakage can only be considered an estimate.

\section{Springs and Seepage Faces}

Springs and seepage faces occur throughout the study area along the Mississippi, Minnesota, and St. Croix Rivers (fig. 29). Most of these features occur in drift above unsaturated sections of bedrock. However, only springs and seeps that are expressions of the first nonperched water table were considered. These were simulated as occurring at the center of the cell that represents the edge of the aquifer. The volume of water lost through springs or seeps was proportional to the head calculated at the center of the node and the altitude of the seep or spring. If the calculated head was the same as or less than the discharge altitude, discharge ceased. In contrast to a leaky river bed, water can only flow out of a seep or a spring, not into it.

\section{Constant Heads}

Constant heads were selected as the boundary condition to represent lakes and the Cannon, Rum, and Crow Rivers (fig. 29). These features principally affect the shape of the water table and shallow ground-water flow. Moreover, 
stage in many lakes in the study area is held nearly constant by control structures. Also, when lake stage drops below a desired level, ground water pumped from wells often is added to the lakes.

\section{Time-Varying Fluxes}

In addition to the boundary conditions at the fixed hydraulic boundaries of the model, fluxes that vary with time must be described. In the aquifer system, recharge from precipitation represents an external flux while pumpage represents an internal flux. Each is discussed below.

\section{Recharge from Precipitation}

Recharge to the aquifer system was simulated by applying a flux of 3.5 in/yr of water to each cell shown on figure 27, except for constant-head cells. This recharge rate represents the flux of water through the bedrock part of the aquifer system and excludes discharge from small, shallow groundwater-flow systems. Long-term trends indicate that 26 to $32 \mathrm{in} / \mathrm{yr}$ of precipitation occurs in the study area (Kuehnast and others, 1975). However, the areal distribution of overland runoff, evapotransporation, discharge from shallow flow systems, and infiltration to deeper flow systems is unknown. Moreover, the estimation of these properties was beyond the scope of this project. Effective recharge was calculated by adding the amount of water induced to flow from lakes into the ground-water-flow system to recharge from the precipitation ( $3.5 \mathrm{in} / \mathrm{yr}$ ).

\section{Pumpage}

All wells pumping more than $10 \mathrm{Mgal} / \mathrm{yr}$ (million gallons per year) were simulated in the model. Intermittent pumpage from known industrial and commercial users pumping 2 to $10 \mathrm{Mgal} / \mathrm{yr}$ also was included. Appendix B lists the withdrawals simulated at each cell.

\section{Mode1 Calibration}

The model was calibrated to show that model variables representing the aquifer system are reasonable for simulation of flow in the aquifer system. Another goal of model calibration is to improve the conceptual model of the aquifer system (Konikow, 1978, p. 88). Model calibration was considered to be satisfactory after the following two conditions were met: (1) successive changes of model variables produced insignificant improvement of model results when compared to observed hydraulic heads and flow, and (2) model sensitivity to variable adjustment was significantly smaller than projected head declines due to future increases in ground-water withdrawals. The model was calibrated in two stages. During the first stage, initial values for model variables, assigned on the basis of available data, were adjusted and model-calculated hydraulic heads were compared to measured hydraulic heads. During the second stage, estimates of aquifer properties and boundary conditions were refined until model-simulated hydraulic heads approximated measured hydraulic heads (Durbin and others, 1978, p. 78, 108) and calculated ground-water fluxes 
compared reasonably to measured fluxes. Only the second stage of model calibration is discussed below. During calibration, model-sensitivity analyses were used to identify the relative effects of adjustments to model input. These analyses are discussed in the next section.

Model variables adjusted during the calibration procedure included horizontal hydraulic conductivity of each aquifer, vertical hydraulic conductivity of each confining unit, recharge rate, leakage through river beds, seepage from seepage faces, the flux along the head-dependent flux boundary (layer 1 ), and the location of constant head nodes representing areas of artificially elevated hydraulic head. Initial, final, and range of values used for horizontal and vertical hydraulic conductivity are given in table 3 . Figures 30 , 31 , and 32 are zonation maps of hydraulic conductivities in the drift, St. Lawrence-Franconia confining unit, and Eau Claire confining unit, respectively. Recharge rates were varied between 2 and $3.75 \mathrm{in} / \mathrm{yr}$. A final value of $3.5 \mathrm{in} / \mathrm{yr}$ was used. Leakage through river beds was varied over a range of 0.001 to 100 times the initial calculated value. The final values were generally 0.1 times the initial value. The simulated flux across the head-dependent flux boundary in layer 1 was adjusted to approximate the flux calculated using Darcy's law. The final flux was 0.1 times the initial flux. Constant heads were added at the location of lakes covering almost all or more than the area of an individual cell. Only lakes with structures that maintain lake stage were considered. The final ground-water budget for the calibration period is given in table 4.

At calibration, model-calculated potentiometric surfaces for layers 1 and 8 (figs. 33a,b) closely resemble measured potentiometric surfaces for the Mount Simon-Hinckley and Prairie du Chien-Jordan aquifers (figs. 13 and 15). In addition, calculated fluxes compare well to measured or estimated fluxes. The flux across the head-dependent-flux boundary along the southern edge of layer $l$ is within $0.5 \mathrm{ft}^{3} / \mathrm{s}$ of the flux independently calculated using Darcy's equation. The calculated flux $\left(173 \mathrm{ft}^{3} / \mathrm{s}\right)$ to the Mississippi and Minnesota Rivers between the streamflow-gaging station located at St. Paul and the next stations upstream (near Anoka and Jordan, respectively) is within the range of measured values for a dry year (January 1977 at $76 \mathrm{ft}^{3} / \mathrm{s}$ ) (U.S. Geological Survey, 1978) and a wetter year (January 1982 at $234 \mathrm{ft}^{3} / \mathrm{s}$ ) (Gunard and others, 1984). Induced flow from lakes amounted to $0.7 \mathrm{in} / \mathrm{yr}$, bringing effective recharge to $4.2 \mathrm{in} / \mathrm{yr}$.

Model-computed steady-state hydraulic heads were compared to mean hydraulic heads measured in 1971-80. Water levels were measured for 1970-71, 197778 , and 1980 in about 500 wells throughout the study area. The median values of these data were used in statistical comparisons with model-calculated heads. Median, rather than mean, values were used to reduce the effect of a single divergent value at an individual site. 


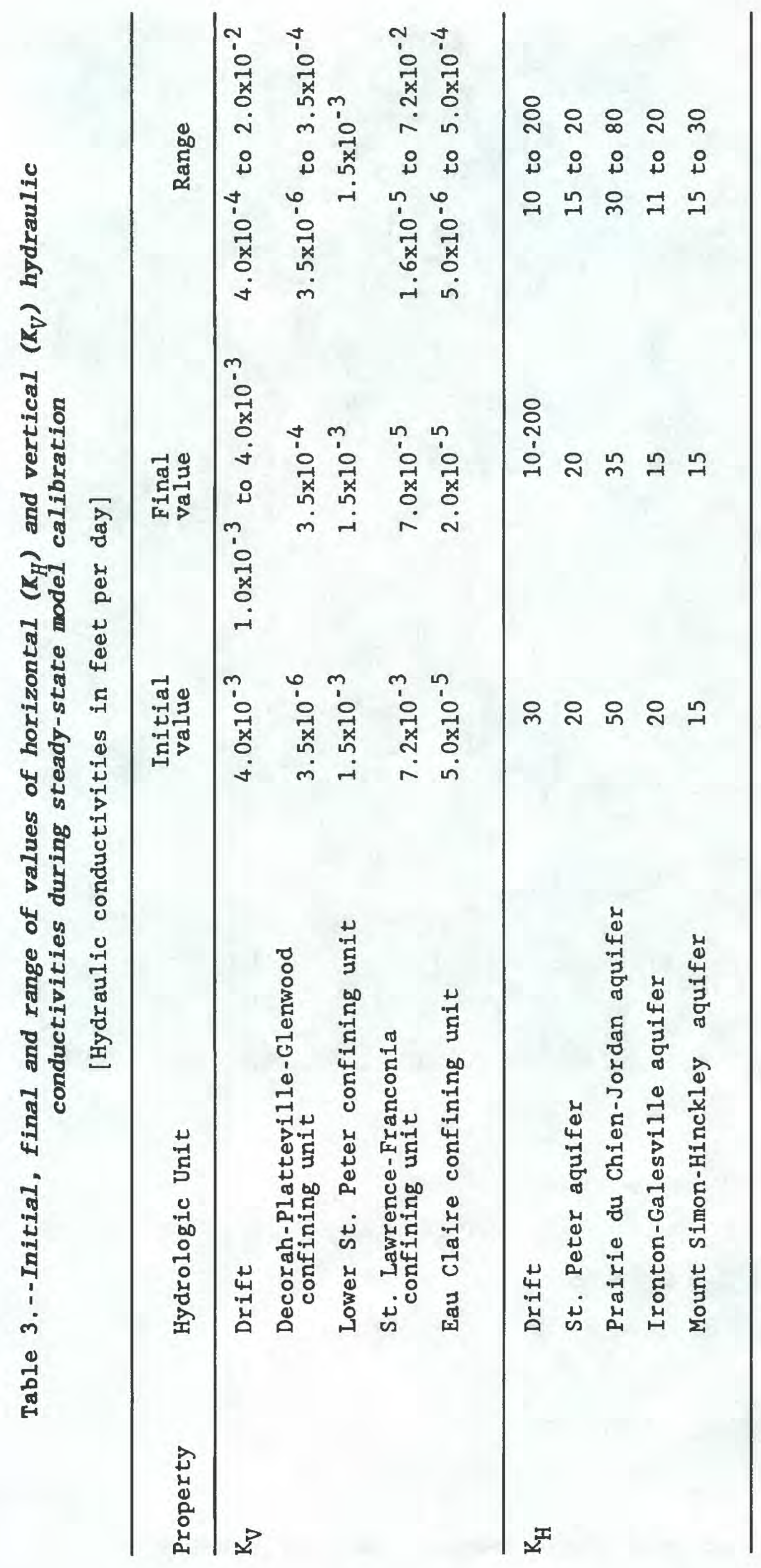




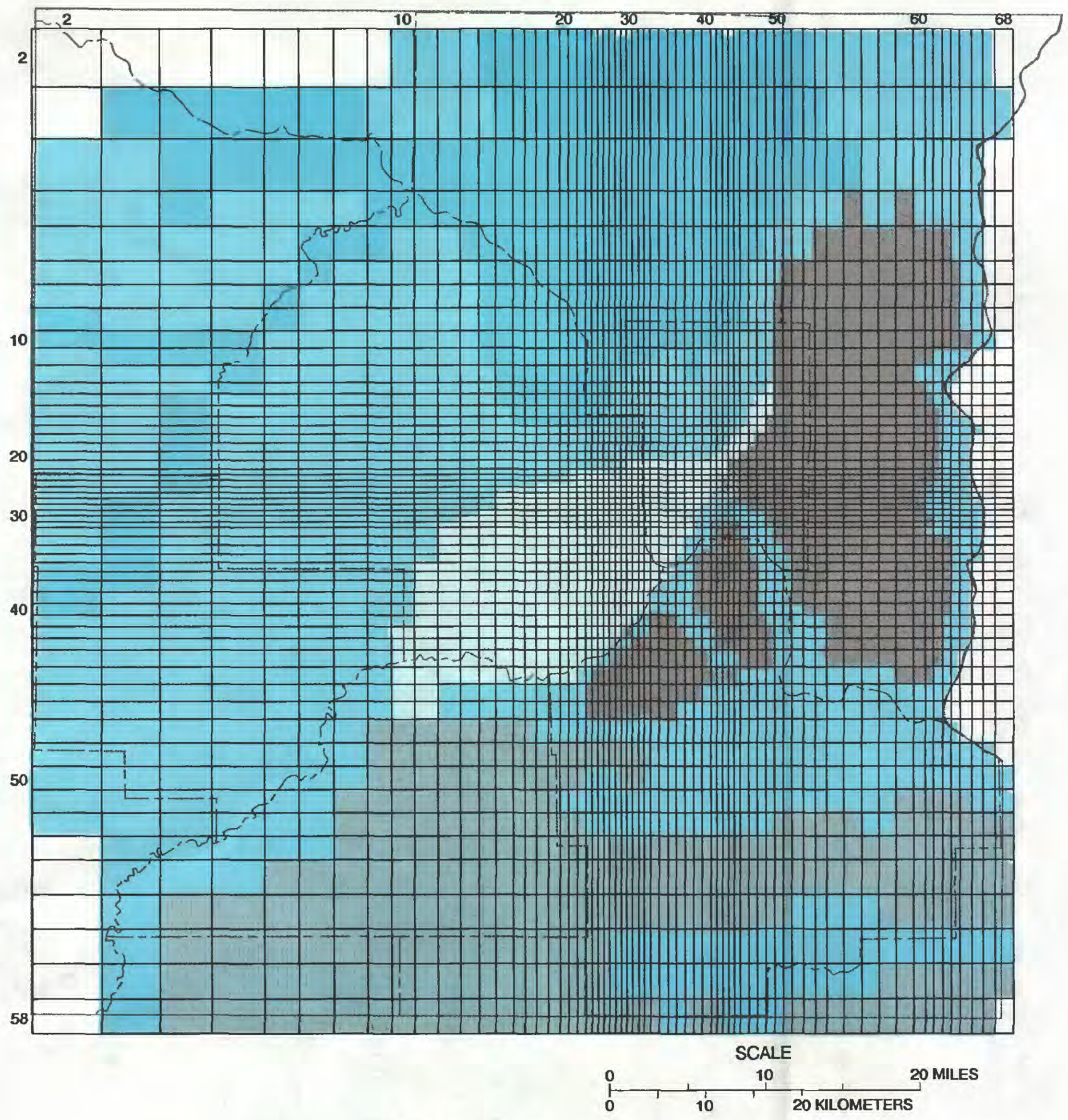

EXPLANATION

ZONE WHERE HORIZONTAL HYDRAULIC CONDUCTIVITY SET TO:

200 feet per day

40 feet per day

30 feet per day

25 feet per day

10 feet per day

Figure 30a.--Zones of horizontal hydraulic conductivity in the drift. 


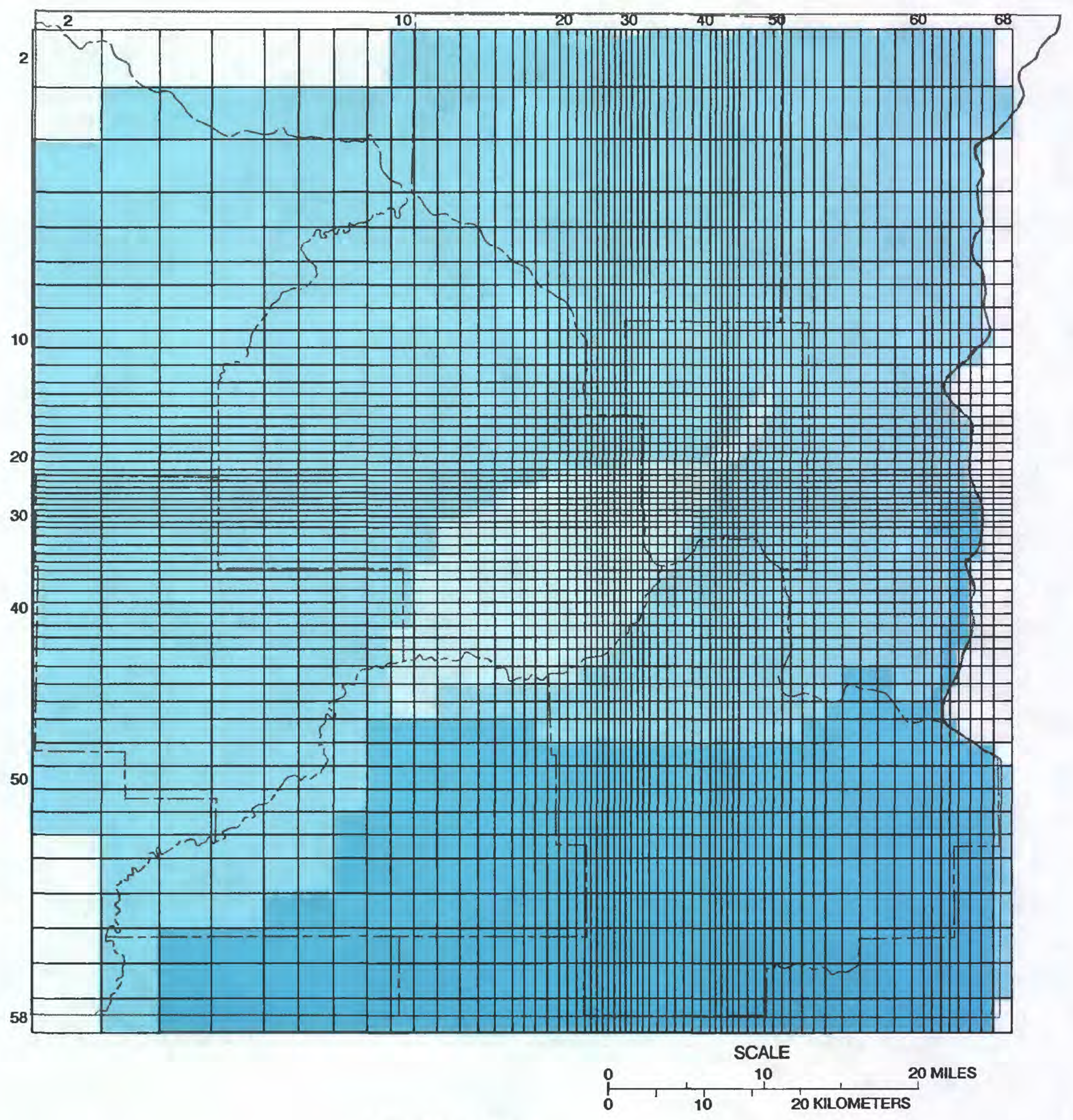

EXPLANATION

ZONE WHERE VERTICAL HYDRAUUIC CONDUCTIVITY SET TO:

$2 \times 10^{-3}$ feet per day

$3 \times 10^{-3}$ feet per day

$4 \times 10^{-3}$ feet per day

Figure 30b.--Zones of vertical hydraulic conductivity in the drift. 


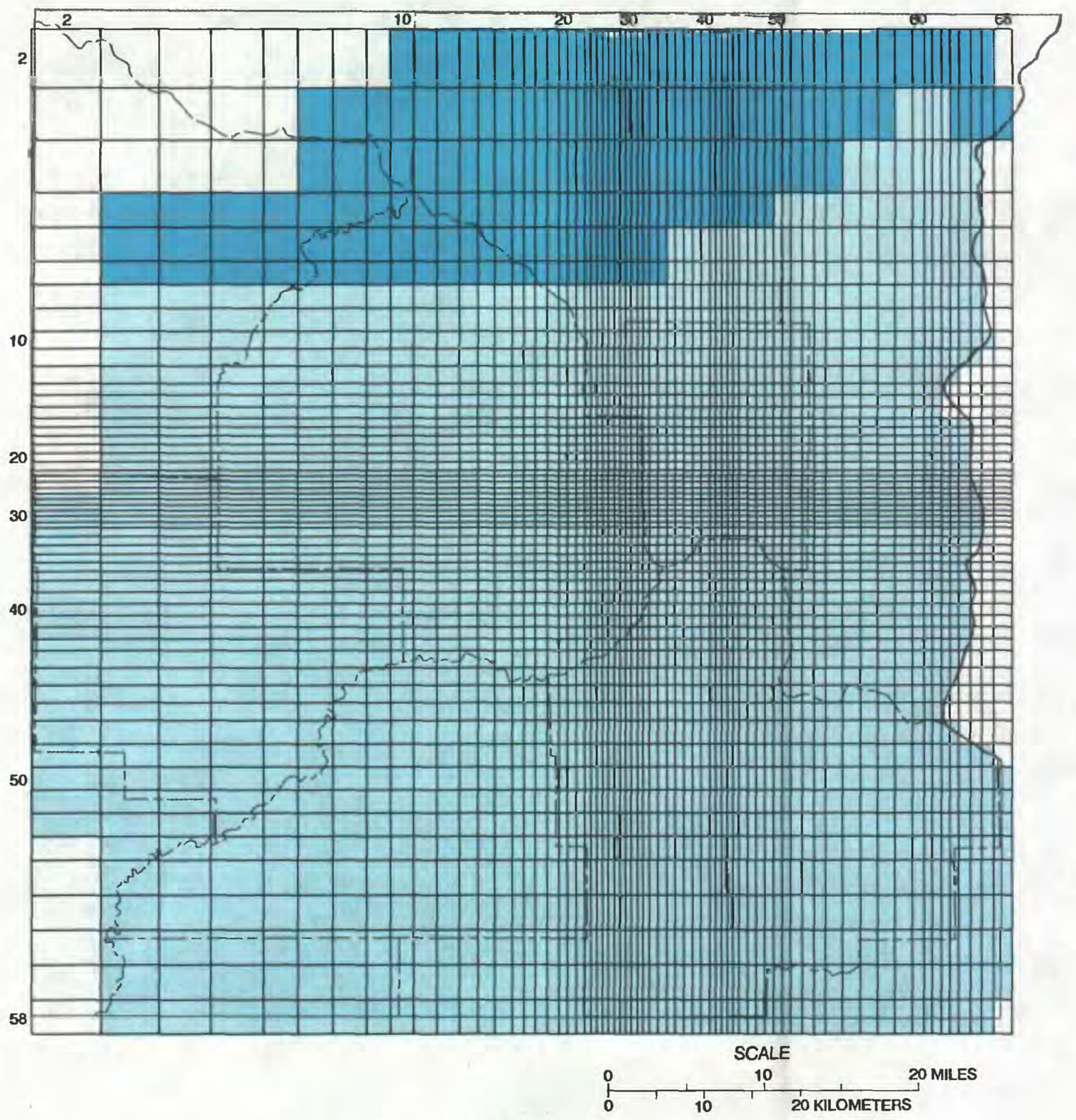

\section{EXPLANATION}

ZONE WHERE VERTICAL HYDRAULIC CONDUCTIVITY SET TO:

0.07 feet per day

$7 \times 10^{-5}$ feet per day

Figure 31.-Zones of vertical hydraulic conductivity in the St. Lawrence-Franconia confining unit. 


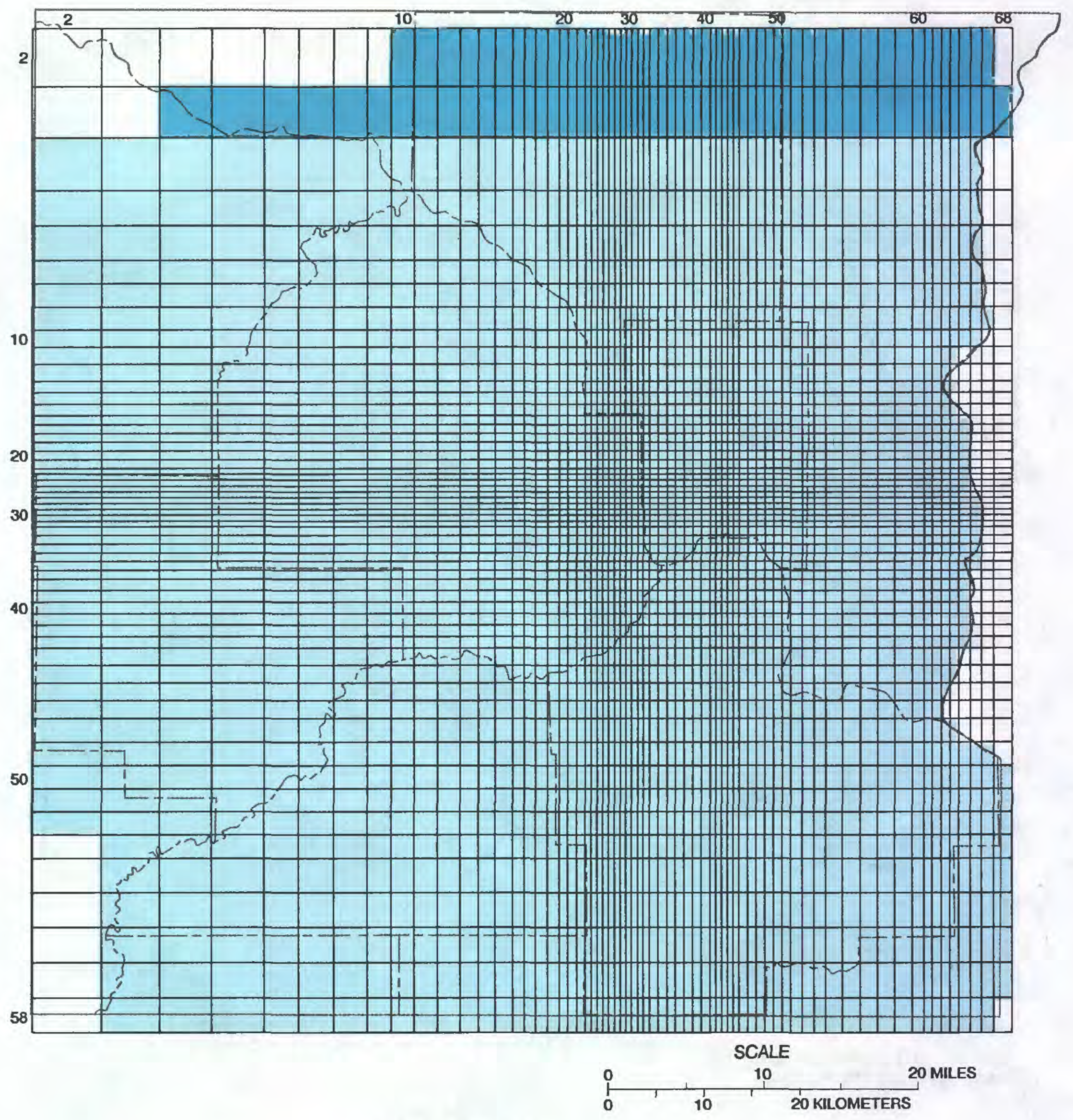

\section{EXPLANATION}

ZONE WHERE VERTICAL HYDRAUUC CONDUCTIVITY SET TO:

0.2 feet per day

$2 \times 10^{-5}$ feet per day

Figure 32.-- Zones of vertical hydraulic conductivity in the Eau Claire confining unit. 

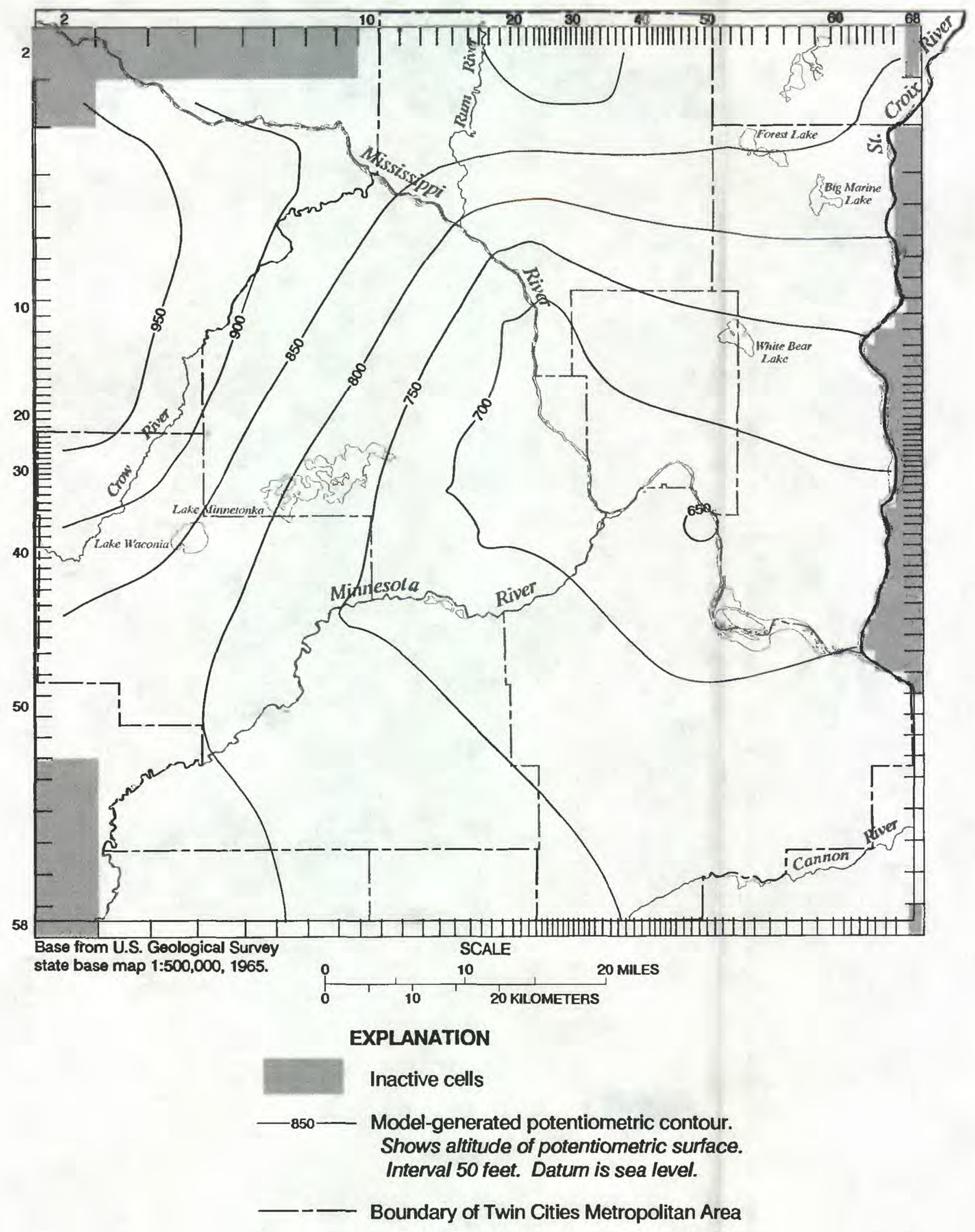

Figure 33a.--Model-calculated potentiometric surface for the calibration period (1970-79) for model layer 1 (Mount Simon-Hinckley aquifer). 


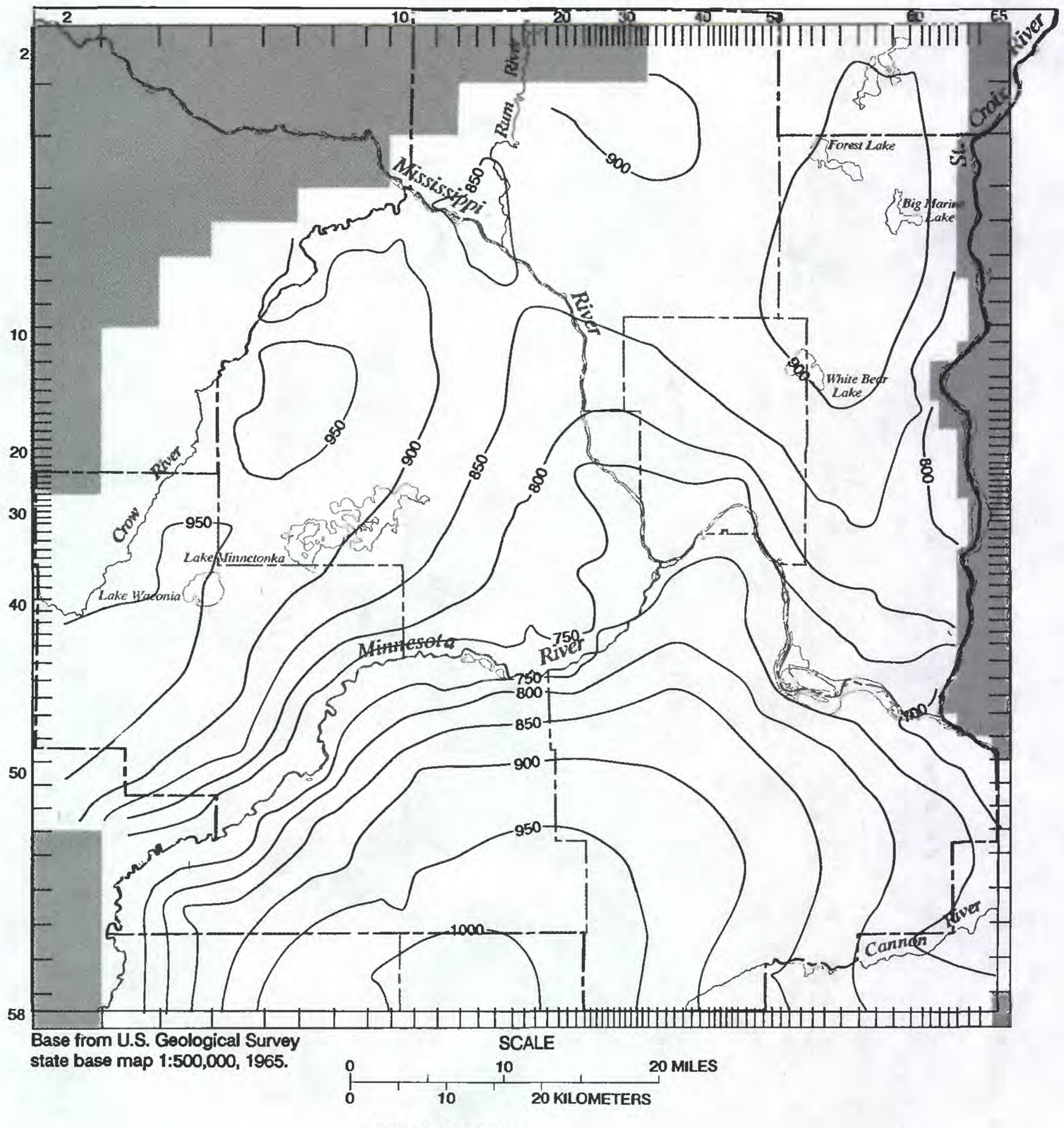

EXPLANATION

Inactive cells

- 850 - Model-generated potentiometric contour. Interval 50 feet. Datum is sea level.

Boundary of Twin Cities Metropolitan Area

Figure 33b.--Model-calculated potentiometric surface for the calibration period (1970-79) for model layer 8 (Prairie du Chien-Jordan aquifer). 


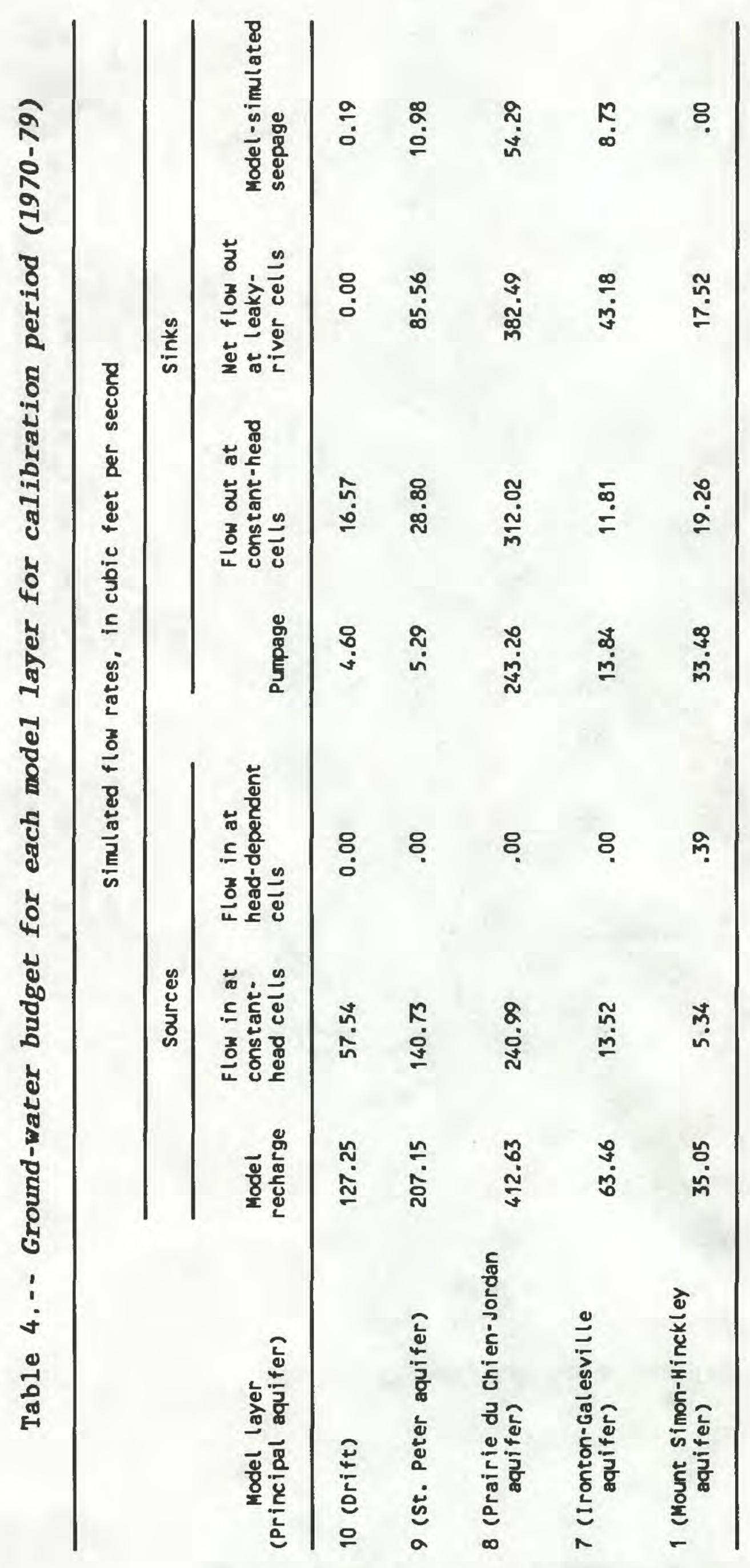


Model calibration was monitored both by use of the standard deviation of the absolute value of the residual and the mean value of the residual and its standard deviation. Residual is here defined as model-simulated head minus measured head. Successive changes in model variables were made so that the mean residual remained close to $0.0 \mathrm{ft}$ ( $\mathrm{fig}$. 34), while the standard deviation of that statistic was reduced (fig. 35). In addition, changes in model variables were made so that mean residuals and their standard deviations for all layers approached each other. This enabled comparisons of results between layers because it suggested that the sets of residuals from each layer had the same distribution of values. Values at the beginning of calibration and after the end of calibration used for the hydraulic properties of the hydrogeologic units also are shown in table 5 .

During model calibration, the standard deviation of the absolute value of the residuals dropped from about 33 to 35 feet to 20 to 25 feet (fig. 31). The greatest improvement in residuals occurred when internal boundaries of the mode1, such as leakage out of seepage faces and river beds, were varied (simulations 12-20) and when the drift was zoned (simulations 20-35). The removal of constant-head boundaries from around model layers 1 to 8 and their replacement with (1) constant head nodes representing interior wetlands, lakes, and peripheral, secondary streams; and (2) head-dependent-flux nodes along the southern edge of layer 1 did not result in overall improvement of the standard deviation of the mean value of the absolute values of the residuals. However, differences between the mean values of the residuals and their associated standard deviations for each layer were reduced. These changes indicated that, as model calibration proceeded, the distribution of the differences between measured and model-calculated heads for each layer became more similar.

Residuals demonstrate the accuracy of the Twin Cities ground-water-flow mode1. For example, the residuals in layer 1 ( $\mathrm{fig} .36 \mathrm{a}$, appendixes $\mathrm{C}$ and D) are smaller (within \pm 25 feet) in the areas of greatest non-municipal pumpage. In areas of large municipal pumpage, residuals ranged from +25 to $+75 \mathrm{ft}$ or from -25 to $-75 \mathrm{ft}$. In layer 7 (appendixes $C$ and $D$ ), positive residuals (about $25 \mathrm{ft}$ to $80 \mathrm{ft}$ ) generally occur where the St. Lawrence-Franconia confining unit is the uppermost bedrock unit and infiltration is increased because erosion may have destroyed the integrity of the confining unit. The largest positive residuals in layer 8 (fig. $36 \mathrm{~b}$, appendixes $C$ and $D$ ) (between 25 and $50 \mathrm{ft}$ ) occurred in cells representing areas adjacent to or near the present-day, incised bedrock valleys that form part of the channels of the Mississippi and Minnesota Rivers. Part of the residuals inherently result from approximations made in model design and part from poorly known or estimated model variables.

Mode1-calculated heads for layer 1 may be inaccurate because of the lack of wells open to the Mount Simon-Hinckley aquifer to the south of the study area. Head data against which to check model accuracy are unavailable and the hydraulic connection between the Mount Simon-Hinckley aquifer and the surface is poorly defined as a result. During model calibration, the southern boundary of layer 1 was insensitive to the use of no-flow and constant-headboundary conditions under steady-state conditions. Consequently, the southern boundary was simulated as a head-dependent-flux boundary, with the source of water about 20 miles farther to the south and a reduced leakage coefficient. The distance coincides with both a topographic and stratigraphic high for the Mount Simon-Hinckley aquifer. 


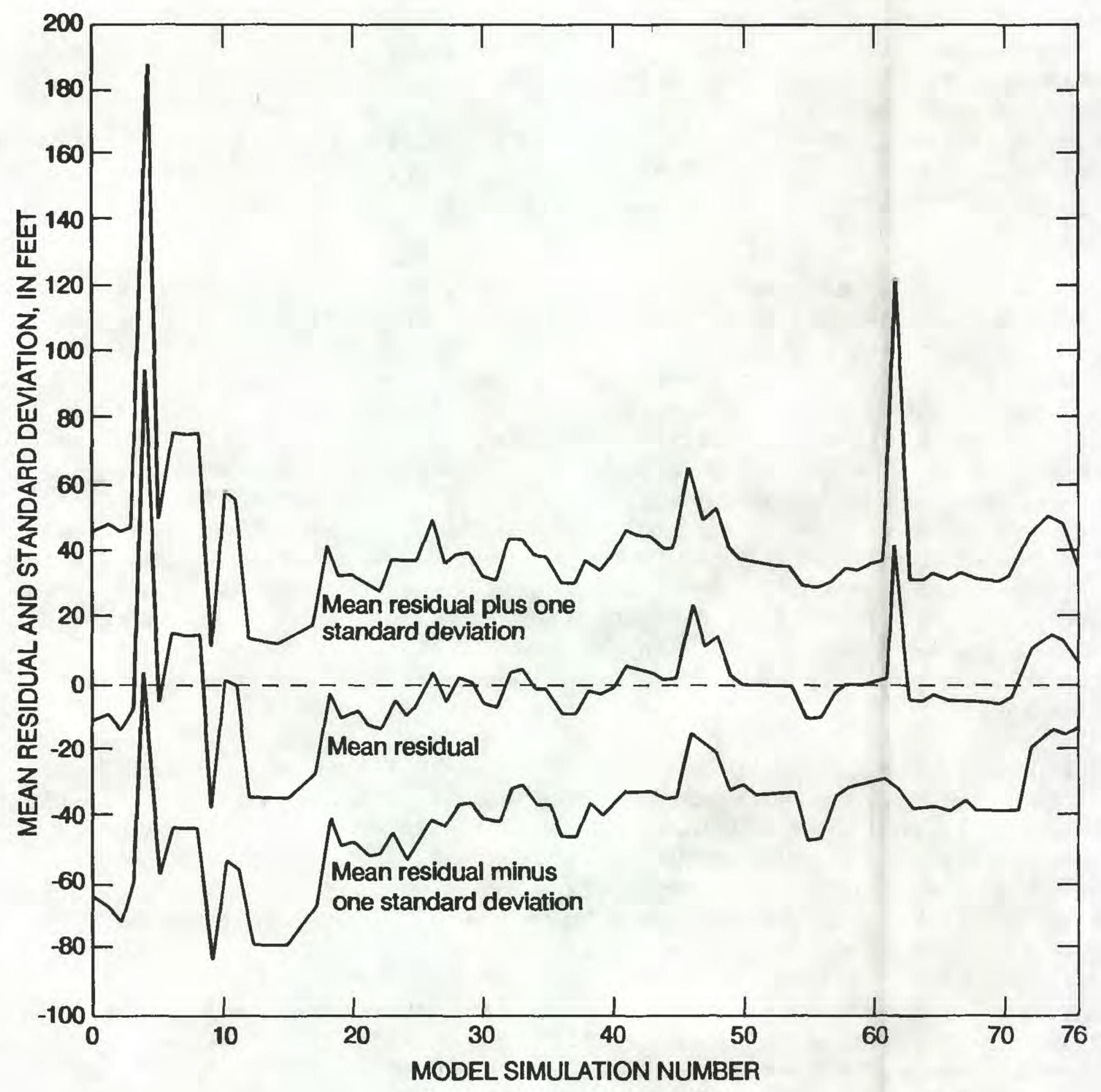

Figure 34.-Change in distribution of two-thirds of differences between observed and model-calculated heads (residuals) during model calibration. 


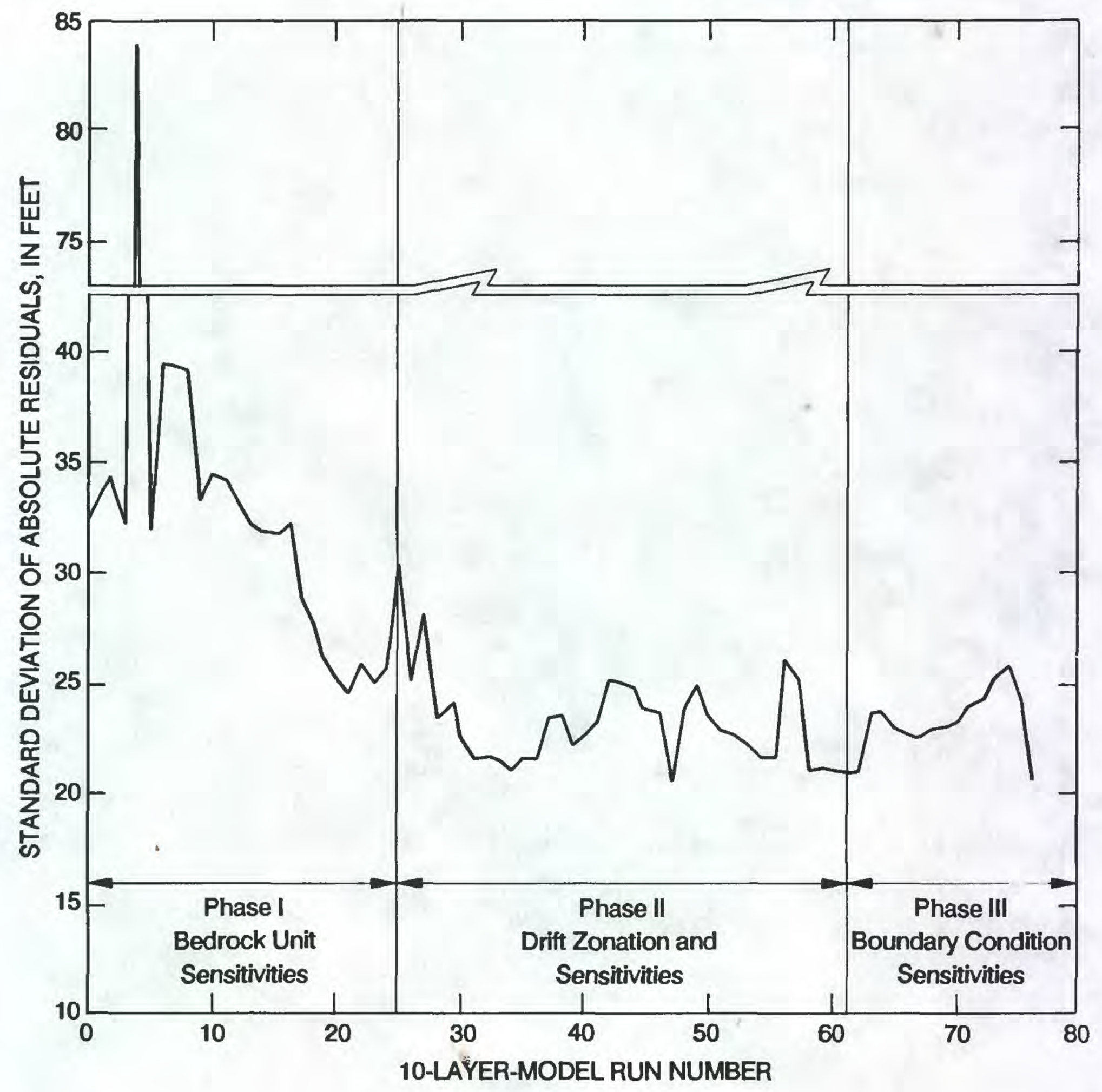

Figure 35.-Changes in standard deviation of the absolute residuals during model calibration. 


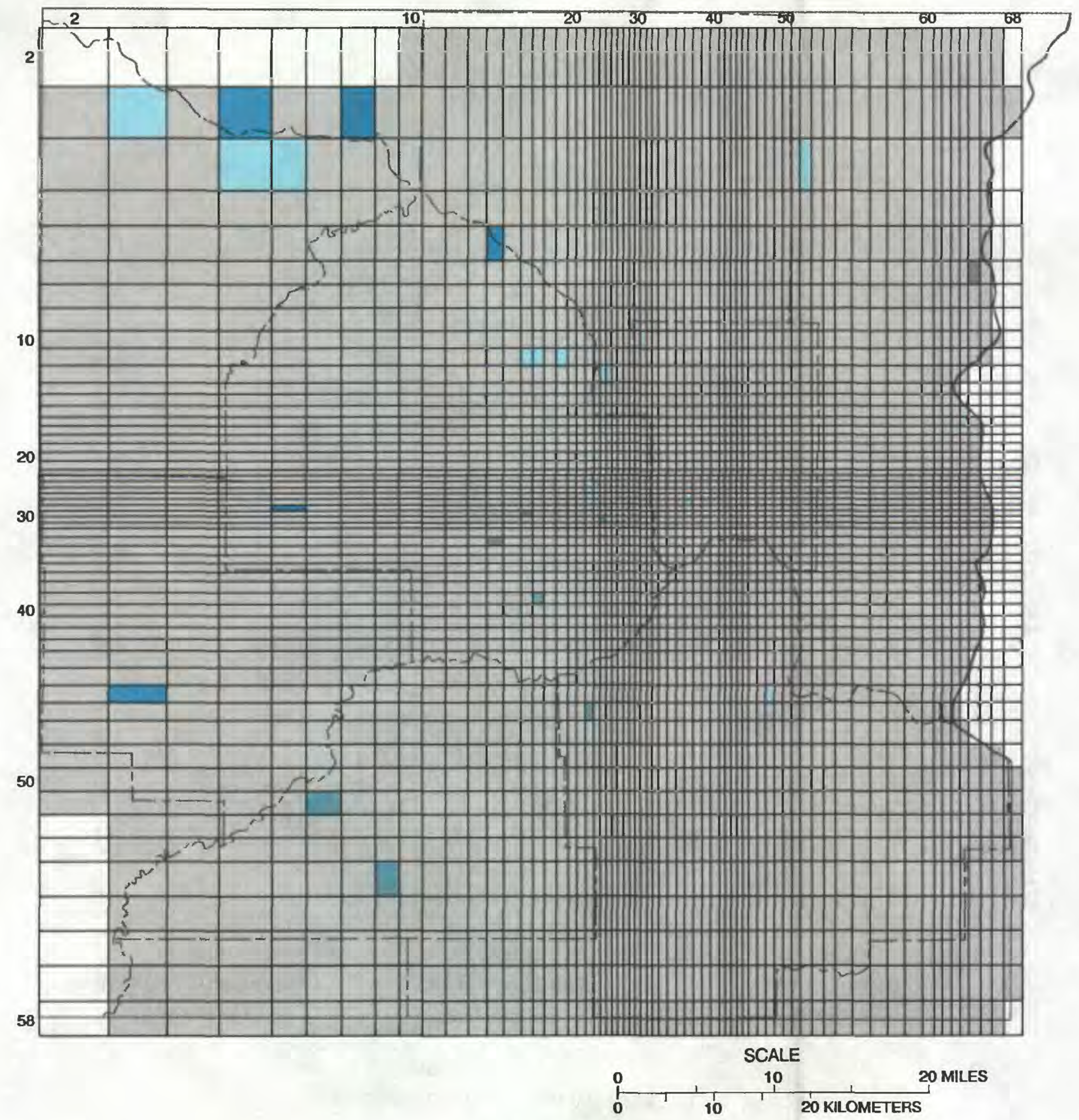

EXPLANATION

R (Model-simulated head) - (Measured head)

$\leq$ Less than or equal to

$<$ Less than

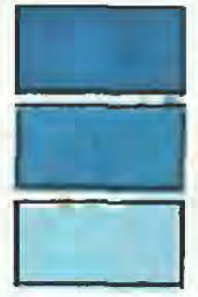

-100 feet $\leq R<-50$ feet

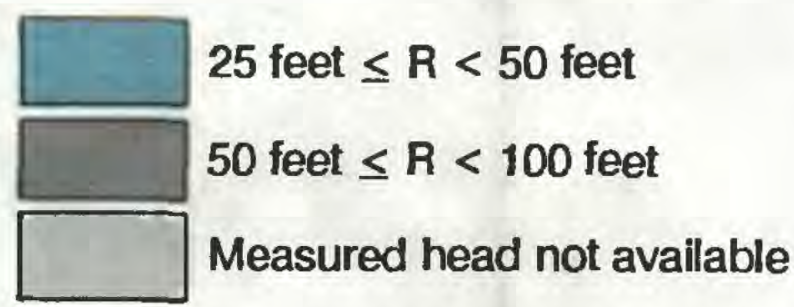

Figure 36a.-Distribution of residuals for model calibration for model layer 1 (contains Mount Simon-Hinckley aquifer). 


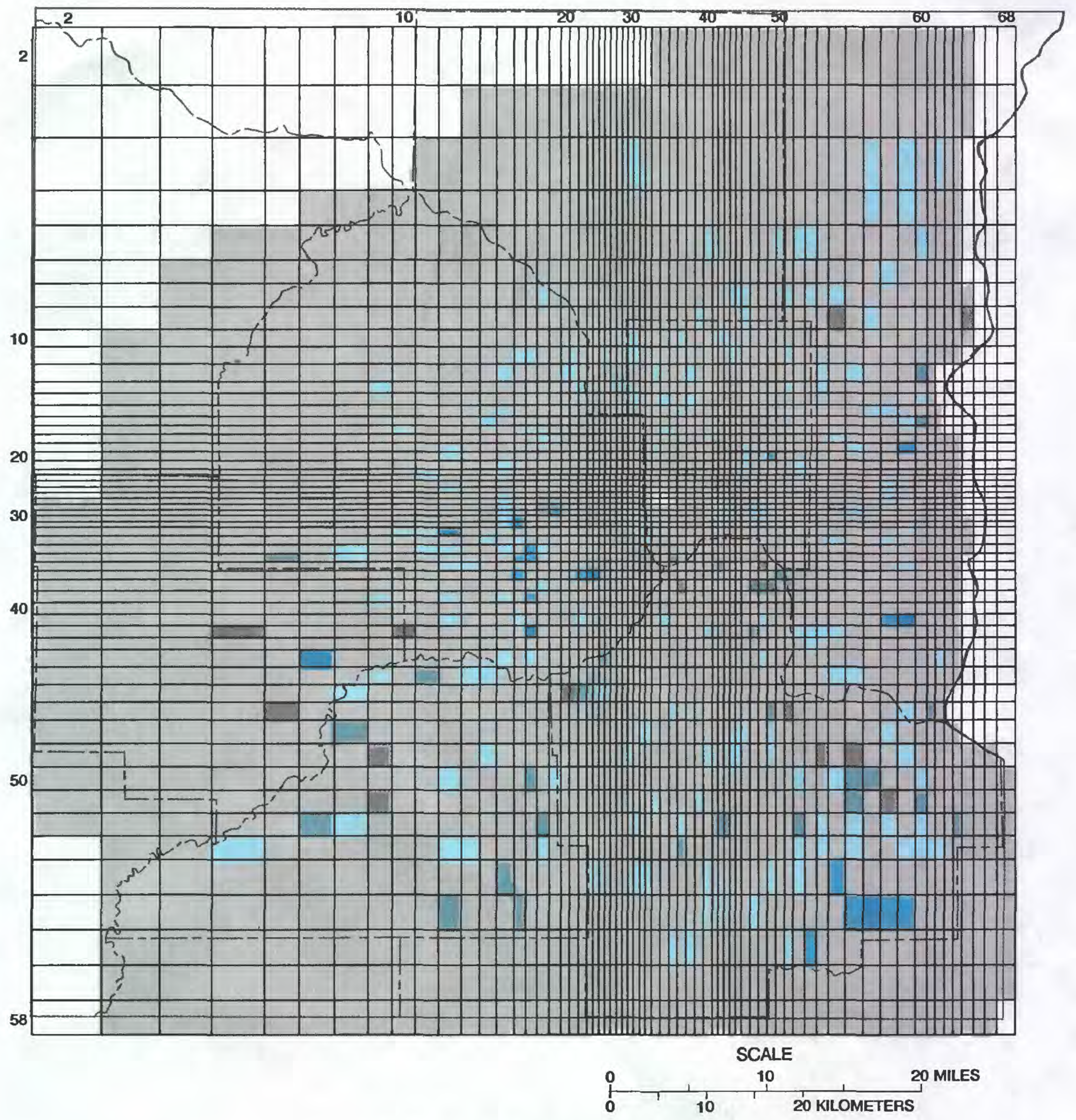

EXPLANATION

R (Model-simulated head) - (Measured head)

$\leq$ Less than or equal to

$<$ Less than

-100 feet $\leq R<-50$ feet
-50 feet $\leq R<-25$ feet
-25 feet $\leq R<25$ feet

$\square$
25 feet $\leq R<50$ feet
50 feet $\leq R<100$ feet
Measured head not available

Figure 36b.--Distribution of residuals for model calibration for model layer 8 (contains Prairies du Chien-Jordan aquifer). 


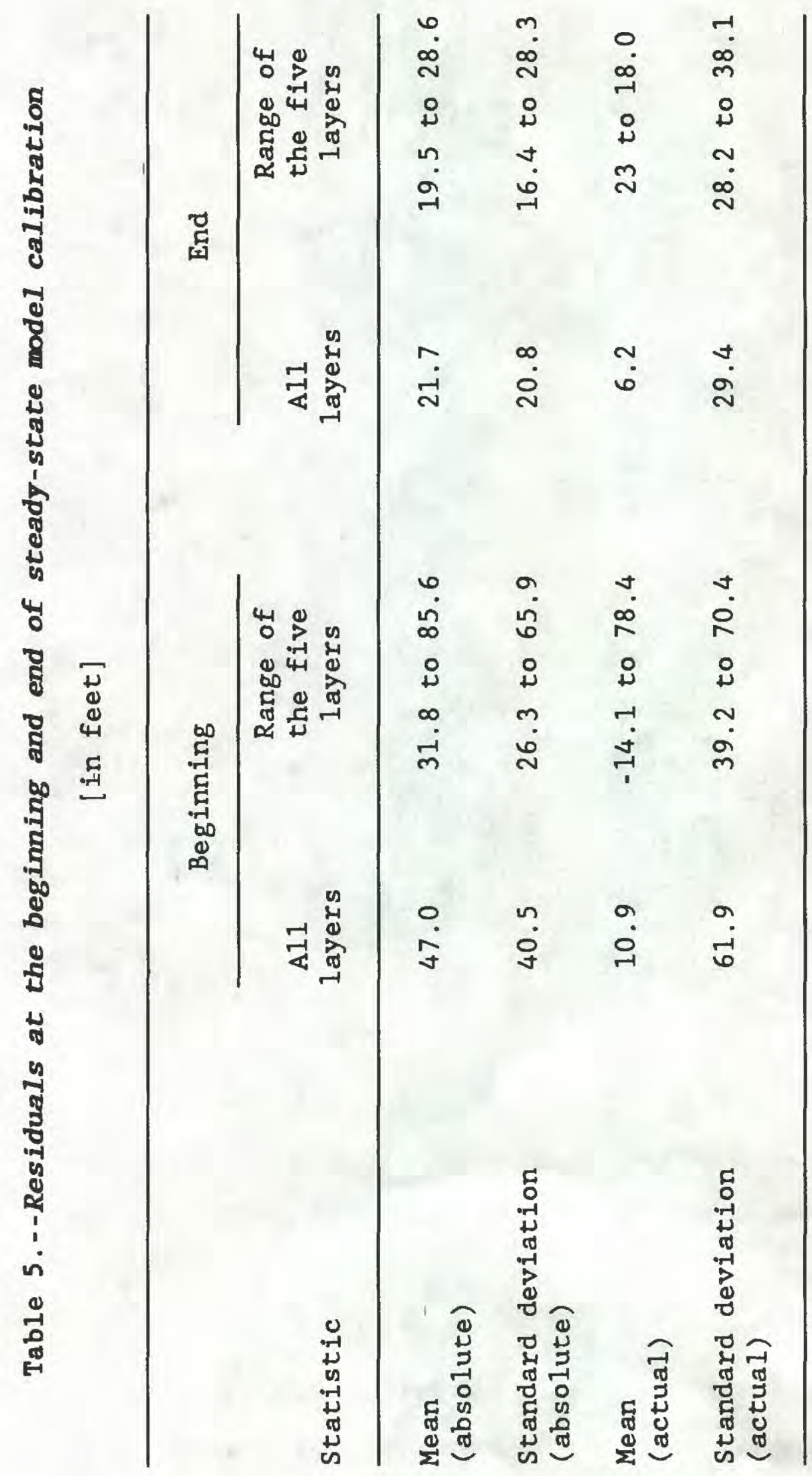


The residuals in layer 8 are related, in part, to five areally dispersed factors. Three relate to the Prairie du Chien-Jordan aquifer. First, approximating the horizontal hydraulic conductivity as a single, regionalized value affects the values of the residuals because this aquifer is, in part, a porous medium and, in part, subject to fracture flow and, in places, only the porous medium part is present. Second, estimates of saturated aquifer thickness affect residuals where the aquifer is unconfined locally. Third, estimates of the saturated thickness of overlying drift affects the values of the residuals where the aquifer is fully saturated as the uppermost bedrock unit. Fourth, at locations where the model layer represents only drift, the underlying confining unit, the St. Lawrence-Franconia, is heavily eroded. The extent of this erosion and its corresponding effect on the vertical hydraulic conductivity of the underlying confining unit are unknown. The accuracy of the approximations made for this variable affects the values of the residuals. Finally, the discordance between the weighting of values of pumpage and hydraulic head affect the value of residuals. The value of the mean annual pumpage in areas of heavy pumpage is weighted toward summer pumpage because most pumpage occurs during that season. In contrast, the value of the mean annual hydraulic head is weighted toward winter hydraulic heads.

Saturated thickness of the Prairie du Chien-Jordan aquifer was calculated by subtracting the thickness of unsaturated bedrock from total bedrock thickness by comparing structural-contour and potentiometric maps. Because the accuracy of each of these maps is $\pm 10 \mathrm{ft}$, accuracy of these estimates is 20 feet.

Transmissivity in the Prairie du Chien-Jordan aquifer was calculated as the product of horizontal hydraulic conductivity and aquifer thickness. Because areal variations of aquifer thickness are well known, horizontal hydraulic conductivity was considered to have a single regional value even though it is known to be locally variable. The major cause of local variability is the buried karst terrain and associated geologic features present in the upper part (Prairie du Chien) of the aquifer. The variations in hydraulic conductivity are not well known.

Where drift is simulated in layer 9 as directly overlying bedrock simulated in layer 8 , the accuracy of the calculated amount of water leaking vertically from the surface to the bedrock depends on the accuracy of the value used for vertical hydraulic conductivity of the drift. The lack of directly obtained values for the vertical hydraulic conductivity of the drift means that this variable must be approximated.

In heavily pumped areas, more water is withdrawn during the five summer months of May-September than during the seven winter months of October-April (Horn, 1983, p. 29). Consequently, the use of mean annual pumpage values weighted model-calculated hydraulic heads toward summer conditions. In contrast, median values of the measured hydraulic heads are weighted toward winter conditions. Hydraulic heads measured during winter tend to reflect values for the whole of winter (see fig. 16 as an example). However, hydraulic heads measured during summer often will be taken either before or after the potentiometric surface is at its lowest. Thus, when a median value is used to represent average hydraulic heads for a year or longer, the composite 
hydraulic head is biased toward winter measurements. In layer 8 , the amount of inaccuracy introduced into model residuals can approach one-half the seasonal variation (Schoenberg, 1984, Plates I and II), or as much as $-30 \mathrm{ft}$.

The model grid was designed to portray important hydrologic features of the ground-water system. Consequently, observation-well locations were not taken into account during grid design and they often are not located near the centers of model cells. Where an observation well is located near the edge of a cell, the model may not accurately simulate the measured hydraulic head when the observation well is in an area of steep hydraulic-head gradients. More than 80 percent of observation-well locations were represented as being more than one-quarter cell width away from the cell center in this model. (Appendixes $C$ and $D$, list the percentage distance that observation wells were from the locations represented by cell centers.) Not considering all comparisons for observation wells both which were more than one-quarter width distant from the cell center and for which the difference between observed and model-calculated heads was greater than 50 feet left 68 percent (376) of the original comparison points. Upon recalculation with the restricted set of calculated and measured hydraulic heads, the absolute value of the mean value of the residuals decreased $4 \mathrm{ft}$, from $29 \mathrm{ft}$ to $25 \mathrm{ft}$. Because the gain in "apparent" fit was small, residuals were calculated using all observations wells.

The real aquifer system equilibrates rapidly to short-term changes in stress (1ike seasonal pumpage) (fig. 16), indicating that a steady-state model can be a suitable approximation of the system for the purpose of this study. Using predevelopment conditions (prior to 1880), corresponding predevelopment heads and fluxes were adequately reproduced with the calibrated model only by adjusting average recharge from 3.5 to $1.75 \mathrm{in} / \mathrm{yr}$. An increase in effective recharge caused by development of large-scale ground-water supplies, as in the Twin Cities Metropolitan Area, could be expected.

Another indication of the model's suitability is the closeness with which it simulates past hydraulic stresses on the aquifer system. Conditions prior to 1880 (predevelopment) represent known conditions which are the most different from the ones for which the model is calibrated. The calibrated model adequately reproduced predevelopment heads and fluxes by adjusting the average recharge to $1.75 \mathrm{in} / \mathrm{yr}$ for predevelopment conditions. Because the model does not simulate that part of precipitation that recharges to and discharges from shallow ground-water flow system, the $1.75 \mathrm{in} / \mathrm{yr}$ difference in recharge can represent the amount of water captured as flow to deeper parts of the system from the shallower parts as hydraulic heads in the deeper parts declined due to pumping. The following observations support this conclusion. The water can be supplied by a slight (about $0.75 \mathrm{ft}$ ) average lowering of the water table over the study area. Many springs, some described as having copious discharge ( 800 to $1,000 \mathrm{gal} / \mathrm{min}$ ) (Winche11, 1889; Thie1, 1944), disappeared during the period of low precipitation from the early 1920's to early 1930's. They did not recur with increasing precipitation during the period 1935-85. Moreover, hydraulic heads in the Mount Simon-Hinckley aquifer changed from being $10 \mathrm{ft}$ higher to $200 \mathrm{ft}$ lower than hydraulic heads in the Prairie du Chien-Jordan aquifer over the period, 1880-1980. Consequently, an increase in the capture of leakage from the water table could be expected in the Twin Cities Metropolitan Area, where large-scale ground-water supplies have been developed. 
During the process of model calibration, individual varlables were adjusted between sequential simulations. The differences in model-calculated heads between model simulations show the model sensitivity to these adjustments. The effects of model adjustments fall into four broad categories: Those factors that directly affect (1) horizontal flow through the groundwater system; (2) vertical flow through the ground-water system; (3) flow influenced by boundary conditions; (4) time-varying fluxes. Results are summarized in table 6 . The model was most sensitive to varlations of vertical-hydraulic conductivity of the drift, vertical-hydraulic conductivity of the St. Lawrence-Franconia confining unit, and recharge rate.

\section{EFFECTS OF PROJECTED GROUND-WATER WITHDRAWALS}

The calibrated, steady-state model was used to evaluate the effects of projected ground-water withdrawals. Four scenarios of projected ground-water withdrawal based on possible future population and economic changes were simulated. Scenario 1 and scenarlo 2 were based on major increases in groundwater withdrawals from the Prairie du Chien-Jordan aquifer and the drift for the years 1990 and 2000, respectively. Scenarlo 3 was based on major increases from the Prairie du Chien-Jordan and Mount Simon-Hinckley aquifers for the year 1990. Scenario 4 was based on major increases from the Prairie du Chien-Jordan aquifer and the drift in the year 2000 under drought conditions. However, by 1986 , actual ground-water withdrawals were $193 \mathrm{Mgal} / \mathrm{d}$ (L. C. Trotta, USGS, oral commun., 1989), significantly less than levels of projected ground-water use made in the early 1980's (Oberts, 1984). Consequently it would appear practical to consider the scenarios as simulations of aquifer response to ground-water withdrawal rates rather than projected responses for specific years.

Stark and Hult (1985, p. 39) showed that calculated heads for a large part of the Twin Cities aquifer system quickly approached equilibrium conditions during each pumping season (4-6 months) during transient simulations . Because knowledge of the long-term effects (greater than a year) of the simulated conditions were desired, all simulations of future development were run to equilibrium. Note that in steady-state simulations, unlike transient simulations, no water is derived from storage. Consequently, use of a steadystate model has the property of being a more severe projection of aquifersystem response to hydrologic stress. Response of the model layers containing the Prairie du Chien-Jordan and Mount Simon-Hinckley aquifers is emphasized because projected ground-water-use increases are concentrated in those aquifers. Results concerning other layers will be discussed where appropriate. 


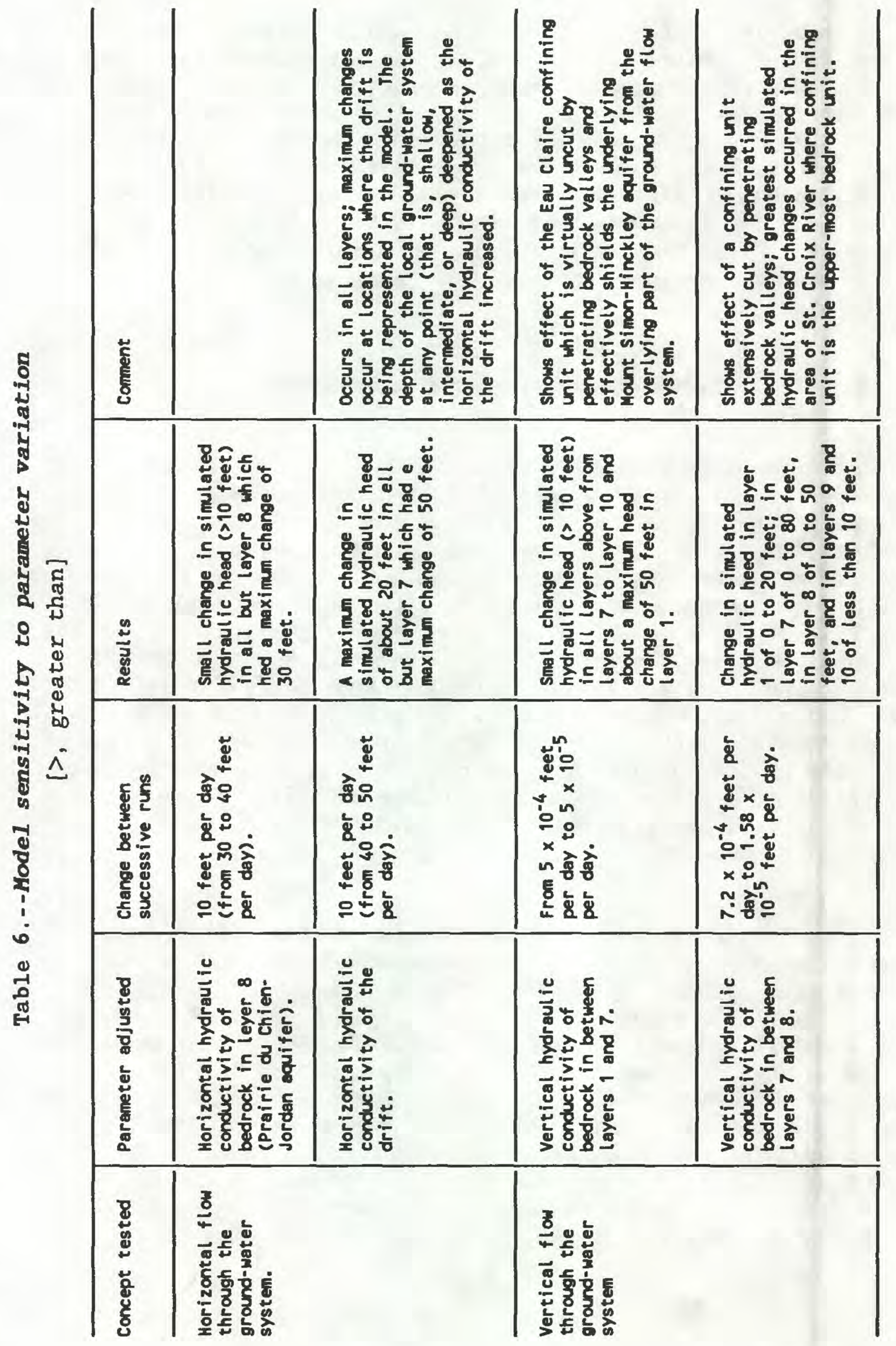




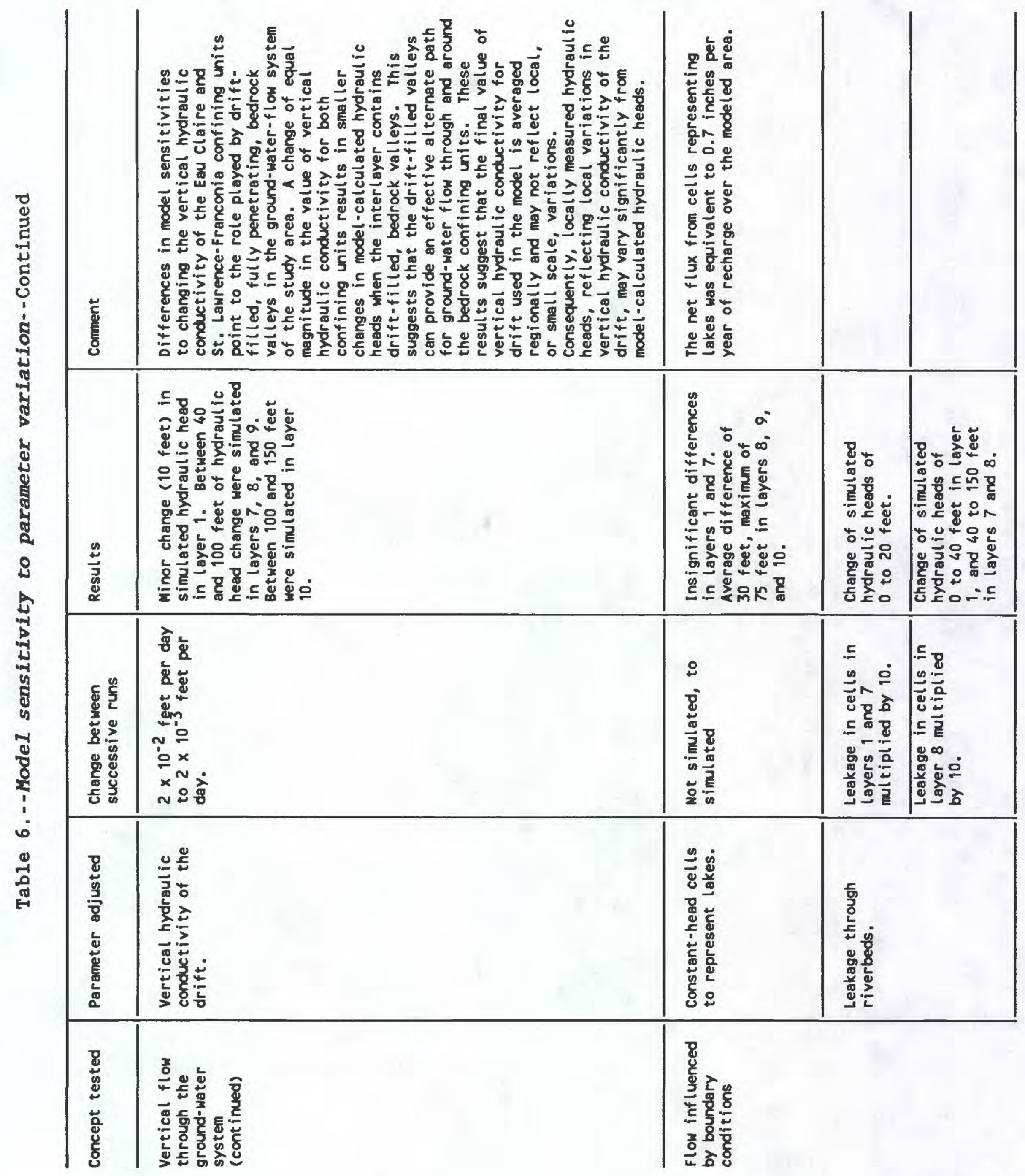




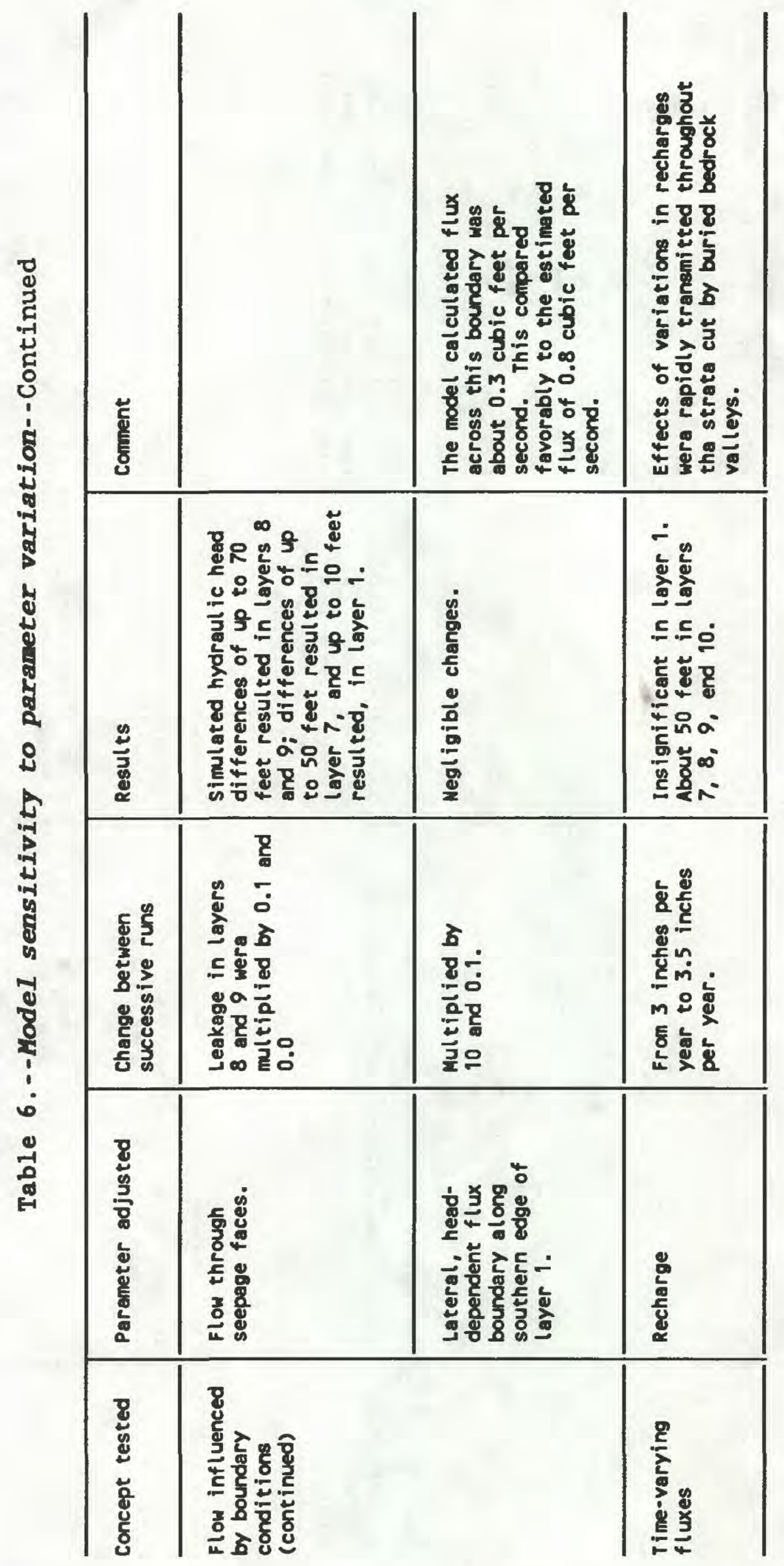




\section{Projected Ground-Water Use}

Pumpage was varied for each scenario. Projected changes of ground-water use in the Twin Cities Metropolitan Area were originally based on projected economic and population growth or decline for the periods 1980-90 and 19802000. Oberts (1983, written communication; 1984) projected the change in demand from 1980 due to economic change, based on interviews with local municipal and township officials throughout the Twin Cities Metropolitan Area (table 7). In addition, he used the results of the 1980 census to estimate the effects of population change on the number of municipal wells in the Twin Cities Metropolitan Area (table 8). Additional projected increases in ground-water use were identified by interviewing water-resource planners for Minneapolis and St. Paul as well as the developers of large construction projects that might use ground water. Table 9 summarizes ground-water withdrawals by aquifer and use type for each scenario. Horn (1983) gives groundwater withdrawals by aquifer and use type for the calibration period.

Projected areal changes in ground-water use were mostly described in terms of political units, such as municipalities and townships. However, in order to simulate projected ground-water withdrawals, this necessitated relating projected changes in ground-water use to specific locations. Most planners interviewed by Oberts (1984) indicated that they expected future withdrawals to be made from aquifers presently pumped. They did not specify the locations of new we11s needed to meet increased demand. Consequently, the locations of wells pumping in 1983 as we11 as the 1980-83 locations of municipal wells and the expected locations of wells at large construction projects in Minneapolis and St. Paul were assumed to be the points of increased future withdrawals. Municipalities that presently withdraw ground water from the Mount Simon-Hinckley aquifer, however, plan to derive future ground-water supplies from drift aquifers, if at all possible. The possible differences in withdrawing ground water from the Mount Simon-Hinckley aquifer instead of aquifers in the drift is described below with two simulations of ground-water use, scenarios 1 and 3. Appendix A 1ists withdrawals by cell for each model 1ayer.

\section{Scenario 1}

Major increases in pumpage from the period 1970-79 are projected from the Prairie du Chien-Jordan aquifer and the drift. The amount of projected increase from these two sources is about $160 \mathrm{Mgal} / \mathrm{d}$ (about 90 percent) out of a total increase of about $175 \mathrm{Mgal} / \mathrm{d}$ for all aquifers. In areas underlain by the Prairie du Chien-Jordan aquifer, increases in ground-water withdrawals were projected to come primarily from that aquifer. The greatest projected increase in ground-water withdrawals (about $130 \mathrm{Mgal} / \mathrm{d}$ ) was simulated as coming from the Prairie du Chien-Jordan aquifer in layer 8 (table 10). The next largest projected increase was simulated as coming from the drift aquifer (about $30 \mathrm{Mgal} / \mathrm{d}$ ) in layers 8 and 9 . Note that table 9 1ists estimated withdrawals by aquifer, while table 10 lists simulated withdrawals by model layer. 
Table 11 lists the ground-water budget for scenario 1. Differences between the simulated potentiometric surfaces and calibration potentiometric surfaces for layers 8 and 1 are shown in figures $37 \mathrm{a}$ and $37 \mathrm{~b}$, respectively. Table 12 lists both the maximum model-calculated head change from the calibration simulation for each withdrawal scenario as well as a detailed listing of all apparent cones of depression simulated by the model.

The simulation indicated that for sccenario 1 the maximum differences from the head calculated for the 1970-79 (calibration) steady-state simulation occur in model layer 8 at the site of the St. Paul Water Utility at Vadnais Lake. Most simulated cones of depression (fig. 38, table 12) are minor. The five largest ones simulated with projected pumpage correspond to areas around the St. Paul Water Utility at Vadnais Heights, Burnsville, Anoka, Blaine, and Coon Rapids.

Table 13 shows calculated values for effective recharge, river leakage, and seepage for all simulations. In these and succeeding simulations, effective recharge represents the long-term (1950-70) average areal recharge from precipitation to the ground-water system ( $3.5 \mathrm{in} / \mathrm{yr}$ ) plus the amount of flow induced from lakes by increased pumpage. River leakage represents the net flow in and out of leaky-river cells, which represent the major rivers in the area (Mississippi, Minnesota, and St. Croix Rivers) as well as flow out of seepage faces and is given in table 14. The constant-head flux represents flow from or into cells along the exterior model boundaries, lakes, and minor rivers (Cannon, Crow, and Rum Rivers). Consequently, total river leakage can be defined as net flow through leaky-river cells plus the constant-head flux for cells representing minor streams and effective recharge as areal recharge from precipitation plus the constant-head flux for cells representing lakes.

The major difference from the 1970-79 (calibration) period is a 17 percent larger effective recharge rate and a 14 percent smaller leakage to major streams (table 13). The major differences in leakage to the streams occur along river segments $3,8,9$, and 10 (fig. 39, table 14). These locations correspond to the Minnesota River and the Mississippi River between its confluence with Rum River and the eastern edge of the model. In terms of absolute and percent differences, along segments $3,8,9$, and 10 , the aquifer system contributed $33,36,84$, and $127 \mathrm{ft}^{3} / \mathrm{s}(12,15,15$, and 19 percent), respectively, less to stream flow. A reversal of flow from river to aquifer, instead of from aquifer to river, is possible along the Mississippi River in the vicinity of downtown Minneapolis. This reversal in flow occurs naturally because the river is perched by the Platteville Formation above the water table just upstream of St. Anthony Falls. At the Falls, the river stage is lowered $75 \mathrm{ft}$. The simulated reversal extended north upstream from the bottom of the Falls to about the northern boundary of Brooklyn Center. Reversals in flow also were projected along the Mississippi River in the vicinity of Nininger and along the Cannon River near Byllesby Reservoir. 
Table 7.--Projected increases in ground-water withdrawals from the year 1980 for the years 1990 and 2000 for commercial and industrial use

[Data supplied by Oberts, G. L. Metropolitan Council of the Twin Cities, written commun. 1983; all units in milifon gallons per year; -.-, value not separated from self-suppiled ground-water withdrawals]

\begin{tabular}{|c|c|c|c|c|c|c|c|c|}
\hline \multirow{3}{*}{$\begin{array}{l}\text { Community } \\
\text { Andover-Rams ey }\end{array}$} & \multicolumn{4}{|c|}{1990} & \multicolumn{4}{|c|}{2000} \\
\hline & \multicolumn{2}{|c|}{$\frac{\text { Municipally supplied }}{\text { commercial industrial }}$} & \multicolumn{2}{|c|}{$\frac{\text { Self-supplied }}{\text { commercial industrial }}$} & \multicolumn{2}{|c|}{$\frac{\text { Municipally supplied }}{\text { commercial industrial }}$} & \multicolumn{2}{|c|}{$\frac{\text { Self-supplied }}{\text { commercial industrial }}$} \\
\hline & .0 & .0 & 40.0 & B. 0 & .0 & .0 & 65.0 & 15.0 \\
\hline Anoka & 6.0 & 5.0 & 21.0 & 15.0 & 21.0 & 14.0 & 41.0 & 29.0 \\
\hline Coon Rapids & 33.0 & 3.0 & 230.0 & 17.0 & 51.0 & 4.0 & 375.0 & 28,0 \\
\hline Blaino & 60.0 & 10.0 & 111.0 & 20.0 & 76.0 & 14.0 & 196.0 & 34.0 \\
\hline Spring Lake Park & -- & -- & 87.0 & 10.0 & -- & -- & 113.0 & 13.0 \\
\hline Fridley & -- & -- & 172.0 & 229.0 & -- & -- & 225.0 & 298.0 \\
\hline Lino Lakes & .0 & .0 & 12.0 & 2.0 & .0 & .0 & 21.0 & 4.0 \\
\hline Columbia Heights & -- & $\cdots$ & 46.0 & 20.0 & -- & -- & 112.0 & 48.0 \\
\hline Chanhassan & 2.0 & 1.0 & 88.0 & 23.0 & 5.0 & 1.0 & 135.0 & 36.0 \\
\hline Chaska & 14.0 & 10.0 & 18.0 & 12.0 & 20.0 & 13.0 & 37.0 & 25.0 \\
\hline Waconia & .0 & .0 & .0 & .0 & 1.0 & .0 & 2.0 & .0 \\
\hline Burnsville & 77.0 & 7.0 & 315.0 & 27.0 & 115.0 & 10.0 & 477.0 & 42.0 \\
\hline Lakeville & 9.0 & 11.0 & 29.0 & 36.0 & 11.0 & 13.0 & 55.0 & 57.0 \\
\hline Apple Valley & 34.0 & 3.0 & 43.0 & 3.0 & 46.0 & 3.0 & 109.0 & 8.0 \\
\hline Farmington & 5.0 & 1.0 & 66.0 & 6.0 & 10.0 & 1.0 & 96.0 & 10.0 \\
\hline Eagan & 47.0 & 13.0 & 459.0 & 129.0 & 68.0 & 19.0 & 771.0 & 217.0 \\
\hline Mandota Haights & --- & -- & 148.0 & 70.0 & -- & $-\infty$ & 220.0 & 108.0 \\
\hline West St. Paul & -- & -- & 205.0 & 25.0 & $\cdots$ & -- & 296.0 & 37.0 \\
\hline South St. Paul & -- & $\cdots$ & 127.0 & 19.0 & -- & -- & 128.0 & 19.0 \\
\hline Rosemount & 3.0 & 1.0 & 70.0 & 13.0 & 8.0 & 1.0 & 108.0 & 21.0 \\
\hline Hastings & 5.0 & 2.0 & 33.0 & 14.0 & 8.0 & 3.0 & 69.0 & 28.0 \\
\hline Chaplin & 3.0 & .0 & 11.0 & .0 & 4.0 & .0 & 24.0 & .0 \\
\hline Maple Grove & 43.0 & 30.0 & 15.0 & 10.0 & 50.0 & 34.0 & 58.0 & 40.0 \\
\hline Brooklyn Park & 33.0 & 4.0 & 181.0 & 25.0 & 43.0 & 6.0 & 260.0 & 36.0 \\
\hline Brooklyn Canter & --- & -- & 191.0 & 39.0 & -- & -- & 243.0 & 50.0 \\
\hline Median & 1.0 & .0 & 43.0 & .0 & 2.0 & .0 & 42.0 & .0 \\
\hline Maple Plain & 1.0 & .0 & .0 & .0 & 1.0 & .0 & .0 & .0 \\
\hline Plymouth & 104.0 & 69.0 & 287.0 & 191.0 & 145.0 & 97.0 & 506.0 & 337.0 \\
\hline Crystal & $\cdots$ & $\cdots$ & 48.0 & 8.0 & -- & $-\infty$ & 74.0 & 13.0 \\
\hline New Hope & -- & $\cdots$ & 55.0 & 35.0 & $\cdots$ & -- & 75.0 & 48.0 \\
\hline Robbinsdale & 1.0 & .0 & 4.0 & .0 & 1.0 & .0 & 4.0 & .0 \\
\hline Minneapolis & --- & $\cdots$ & 604.0 & 142.0 & $\cdots$ & $\cdots$ & 842.0 & 198.0 \\
\hline Golden Valley & --- & $\cdots$ & 107.0 & 75.0 & -- & -- & 171.0 & 118.0 \\
\hline
\end{tabular}


Table 7.--Projected increases in ground-water withdrawals from the year 1980 for the years 1990 and 2000 for commercial and industrial use--Continued

\begin{tabular}{|c|c|c|c|c|c|c|c|c|}
\hline \multirow{3}{*}{$\begin{array}{l}\text { Community } \\
\text { Long Lake }\end{array}$} & \multicolumn{4}{|c|}{1990} & \multicolumn{4}{|c|}{2000} \\
\hline & \multicolumn{2}{|c|}{$\frac{\text { Municipally supplied }}{\text { commercial industrial }}$} & \multicolumn{2}{|c|}{$\frac{\text { Self-supplied }}{\text { commercial industrial }}$} & \multicolumn{2}{|c|}{$\frac{\text { Municipally supplied }}{\text { commercial industrial }}$} & \multicolumn{2}{|c|}{$\frac{\text { Self-supplied }}{\text { commercial industrial }}$} \\
\hline & 1.0 & 1.0 & 5.0 & 3.0 & 2.0 & 1.0 & 8.0 & 5.0 \\
\hline Wayzata & 2.0 & .0 & 8.0 & .0 & 3.0 & .0 & 14.0 & .0 \\
\hline Minnetonka & 34.0 & 12.0 & 280.0 & 94.0 & 55.0 & 18.0 & 300.0 & 100.0 \\
\hline Hopkins & -- & -- & 164.0 & 85.0 & -- & -- & 186.0 & 85.0 \\
\hline St. Louis Park & --- & -- & 186.0 & 52.0 & -- & -- & 137.0 & 38.0 \\
\hline Edina & 6.0 & 1.0 & 402.0 & 45.0 & -- & -- & 408.0 & 46.0 \\
\hline Richfield & -- & -- & 27.0 & .0 & -- & $\cdots$ & 27.0 & .0 \\
\hline Eden Prairie & 19.0 & 14.0 & 531.0 & 418.0 & 36.0 & 28.0 & 730.0 & 574.0 \\
\hline Bloomington & 67.0 & 39.0 & 532.0 & 313.0 & 68.0 & 40.0 & 665.0 & 385.0 \\
\hline Ft. Snelling & .0 & .0 & 196.0 & .0 & .0 & .0 & 284.0 & .0 \\
\hline Excelsior & --- & $\cdots$ & 30.0 & .0 & .0 & .0 & 28.0 & .0 \\
\hline Spring Park & .0 & .0 & 5.0 & .0 & 1.0 & .0 & 4.0 & .0 \\
\hline St. Paul & -- & -- & 553.0 & 204.0 & -- & -- & 780.0 & 288.0 \\
\hline Roseville & --- & -- & 335.0 & 150.0 & -- & $\cdots$ & 400.0 & 180.0 \\
\hline Maplewood & -- & -- & 156.0 & 304.0 & -- & -- & 232.0 & 448.0 \\
\hline North St. Paul & 4.0 & 1.0 & 25.0 & 3.0 & 8.0 & 1.0 & 21.0 & 3.0 \\
\hline White Bear Lake & 3.0 & .0 & 15.0 & 2.0 & 4.0 & .0 & 32.0 & 4.0 \\
\hline Vadnais Heights & 6.0 & 3.0 & .0 & .0 & 9.0 & 3.0 & 4.0 & 2.0 \\
\hline Little Canada & -- & -- & 53.0 & 6.0 & -- & -- & 88.0 & 11.0 \\
\hline Arden Bills & $-\cdots$ & -- & 29.0 & 46.0 & -- & $\cdots$ & 46.0 & 74.0 \\
\hline New Bright & 4.0 & 3.0 & 82.0 & 66.0 & 5.0 & 4.0 & 88.0 & 84.0 \\
\hline Mounds View & 3.0 & .0 & 48.0 & 4.0 & 4.0 & .0 & 98.0 & 7.0 \\
\hline Shoreview & 6.0 & 7.0 & 11.0 & 14.0 & 8.0 & 11.0 & 23.0 & 30.0 \\
\hline Shakopee & 24.0 & 10.0 & 236.0 & 92.0 & 38.0 & 15.0 & 386.0 & 154.0 \\
\hline Savage & 3.0 & 4.0 & 80.0 & 126.0 & 5.0 & 7.0 & 116.0 & 162.0 \\
\hline Prior Lake & 23.0 & 1.0 & 13.0 & .0 & 34.0 & 1.0 & 48.0 & 2.0 \\
\hline Hugo & 1.0 & .0 & 8.0 & 4.0 & 1.0 & .0 & 15.0 & 7.0 \\
\hline Stillwater & 4.0 & .0 & 44.0 & 4.0 & 5.0 & .0 & 43.0 & 4.0 \\
\hline Oak Park Heights & 4.0 & .0 & 38.0 & .0 & 5.0 & .0 & 86.0 & .0 \\
\hline Oakdale & 3.0 & 2.0 & 42.0 & 28.0 & 5.0 & 8.0 & 76.0 & 50.0 \\
\hline Lake Elmo & .0 & .0 & 13.0 & .0 & .0 & .0 & 28.0 & .0 \\
\hline Woodbury & 55.0 & 8.0 & 94.0 & 13.0 & 84.0 & 11.0 & 172.0 & 24.0 \\
\hline Newport & 2.0 & 1.0 & 3.0 & 1.0 & 4.0 & 1.0 & 8.0 & 2.0 \\
\hline Cottage Grove & 6.0 & 5.0 & 21.0 & 16.0 & 10.0 & 8.0 & 44.0 & 34.0 \\
\hline Forest Lake & 3.0 & .0 & 45.0 & 7.0 & 4.0 & .0 & 70.0 & 11.0 \\
\hline
\end{tabular}


Table 8.--Number of additional wells needed

to meet population growth

(Source: Oberts, G. L. Metropolitan Council of the Iwin Cities, written commun. 1983)

\begin{tabular}{|c|c|c|c|}
\hline \multirow[b]{2}{*}{ Community } & \multirow[b]{2}{*}{ County } & \multicolumn{2}{|c|}{$\begin{array}{l}\text { Number of edditional wells } \\
\text { needed by year: }\end{array}$} \\
\hline & & 1990 & 2000 \\
\hline Maple Grove & Bennepin & 8 & 1 \\
\hline P1ymouth & Bennepin & 6 & 3 \\
\hline Eagan & Dakota & 6 & 3 \\
\hline Brooklyn Park & Bennepin & 5 & 2 \\
\hline Bleine & Anoka & 5 & 1 \\
\hline Coon Repids & Anoke & 4 & 3 \\
\hline Eden Prairie & Hennepin & 4 & 3 \\
\hline Bloomington & Bennepin & 4 & 0 \\
\hline Burnsville & Dakota & 4 & 2 \\
\hline Apple Valley & Dakota & 4 & 2 \\
\hline Woodbury & Washington & 3 & 2 \\
\hline Minnetonka & Bennepin & 2 & 2 \\
\hline Inver Grove Heights & Dakota & 2 & 0 \\
\hline Cottage Grove & Washington & 2 & 1 \\
\hline Shoreview & Ramsey & 2 & 1 \\
\hline Vadnais Reights & Ramsey & 2 & 1 \\
\hline Lakeville & Dakota & 2 & 1 \\
\hline Mound & Bennepin & 1 & 0 \\
\hline Chaska & Carver & 1 & 0 \\
\hline Shakopee & Scott & 1 & 0 \\
\hline Prior Lake & Scott & 1 & 1 \\
\hline Savage & Scott & 1 & 1 \\
\hline Oakdale & Washinton & 1 & 1 \\
\hline White Bear Lake & Ramsey & 1 & 1 \\
\hline Andover & Anoka & 1 & 2 \\
\hline Champlin & Hennepin & 1 & 1 \\
\hline Hastings & Dakota & 1 & 0 \\
\hline Anoka & Anoka & 0 & 1 \\
\hline Mounds View & Ramsey & 0 & 1 \\
\hline New Brighton & Ramsey & 0 & 1 \\
\hline Arden Hills & Ransey & 0 & 1 \\
\hline Little Canada & Ramsey & 0 & 1 \\
\hline Lake E1mo & Washington & 0 & 1 \\
\hline Rosemount & Dakota & 0 & 1 \\
\hline Bugo & Washington & 0 & 1 \\
\hline Farmington & Dakota & 0 & 1 \\
\hline
\end{tabular}


Table 9.--Estimated ground-water withdrawals by aquifer and use type for each scenario

[in million gallons per day]

\begin{tabular}{|c|c|c|c|c|c|c|}
\hline Simulation & Use type & $\begin{array}{l}\text { Mount } \\
\text { Simon- } \\
\text { Hinckley } \\
\text { aquifer }\end{array}$ & $\begin{array}{l}\text { Ironton- } \\
\text { Galesvil1e } \\
\text { aquifer }\end{array}$ & $\begin{array}{l}\text { Prairie } \\
\text { due Chien- } \\
\text { Jordan } \\
\text { aquifer }\end{array}$ & $\begin{array}{l}\text { St. Peter } \\
\text { aquifer }\end{array}$ & $\begin{array}{l}\text { Drift } \\
\text { aquifer }\end{array}$ \\
\hline \multirow[t]{7}{*}{ Scenario 1} & Muncipal & 23.408 & 11.149 & 183.119 & 0.292 & 34.883 \\
\hline & Commercial & 1.160 & .350 & 29.850 & .050 & 1.275 \\
\hline & Industrial & 3.562 & 2.192 & 50.241 & .023 & 2.922 \\
\hline & Irrigation & .345 & .185 & 11.303 & .045 & 1.291 \\
\hline & Mining & 0 & 0 & 11.860 & 0 & 0 \\
\hline & Total & 28.475 & 13.876 & 286.373 & 0.860 & 40.317 \\
\hline & & & & & & Tota1 use 369.955 \\
\hline \multirow[t]{7}{*}{ Scenario 2} & Muncipal & 29.593 & 12.827 & 258.428 & .304 & 52.108 \\
\hline & Commercial & 2.621 & .815 & 51.668 & .091 & 2.831 \\
\hline & Industrial & 4.258 & 2.404 & 60.300 & .042 & 3.645 \\
\hline & Irrigation & .345 & .185 & 11.303 & .045 & 1.291 \\
\hline & Mining & 0 & 0 & 11.860 & 0 & 0 \\
\hline & Total & 36.817 & 16.231 & 393.619 & .482 & 59.875 \\
\hline & & & & & & Total use 507.024 \\
\hline \multirow[t]{7}{*}{ Scenario 3} & Muncipal & 35.901 & 12.837 & 182.207 & .292 & 24.227 \\
\hline & Commercial & 1.950 & .417 & 29.302 & .050 & .966 \\
\hline & Industrial & 3.929 & 2.223 & 49.986 & .023 & 2.778 \\
\hline & Irrigation & .345 & .185 & 11.303 & .045 & 1.291 \\
\hline & Mining & 0 & 0 & 11.860 & 0 & 0 \\
\hline & Total & 42.125 & 15.662 & 284.658 & .860 & 29.262 \\
\hline & & & & & & Total use 372.567 \\
\hline \multirow[t]{7}{*}{ Scenario 4} & Muncipal & 40.483 & 17.829 & 348.361 & .760 & 74.848 \\
\hline & Commercial & 2.794 & .869 & 55.093 & .097 & 3.019 \\
\hline & Industrial & 5.367 & 3.031 & 76.084 & .053 & 4.594 \\
\hline & Irrigation & .517 & .277 & 16.955 & .068 & 1.937 \\
\hline & Mining & 0 & 0 & 11.860 & 0 & 0 \\
\hline & Total & 49.161 & 22.006 & 508.353 & .978 & 84.398 \\
\hline & & & & & & Total use 664.896 \\
\hline
\end{tabular}


Table 10.--Simulated withdrawals for model calibration and development scenarios by model layer

[Upper number is withdrawals in million gallons per day; lower number is cubic feet per second]

Mode1 layer

(principal

aquifer

Calibration

Period

in layer)

(1970-79)

Scenario 1 Scenario 2 Scenario 3 Scenario 4

\begin{tabular}{|c|c|c|c|c|c|}
\hline $\begin{array}{c}10 \\
\text { (Drift) }\end{array}$ & $\frac{3.0}{4.6}$ & $\frac{3.2}{5.0}$ & $\frac{3.6}{5.6}$ & $\frac{3.2}{5.0}$ & $\frac{4.8}{7.5}$ \\
\hline${ }^{9}{ }^{9}$ (St. Peter) & $\frac{3.4}{5.3}$ & $\frac{17.2}{26.6}$ & $\frac{30.2}{46.7}$ & $\frac{16.3}{25.3}$ & $\frac{45.2}{70.0}$ \\
\hline $\begin{array}{c}8 \\
\text { (Prairie } \\
\text { du Chien- } \\
\text { Jordan) }\end{array}$ & $\frac{157.3}{243.3}$ & $\frac{305.0}{471.9}$ & $\frac{417.8}{646.3}$ & $\frac{293.0}{453.3}$ & $\frac{542.4}{839.1}$ \\
\hline $\begin{array}{c}7 \\
\text { (Ironton- } \\
\text { Galesville) }\end{array}$ & $\frac{8.9}{13.8}$ & $\frac{13.9}{21.5}$ & $\frac{16.3}{25.2}$ & $\frac{15.7}{24.3}$ & $\frac{22.0}{34.1}$ \\
\hline $\begin{array}{c}1 \\
\text { (Mount } \\
\text { Simon- } \\
\text { Hinckley) }\end{array}$ & $\frac{21.7}{33.5}$ & $\frac{28.5}{44.1}$ & $\frac{36.9}{57.1}$ & $\frac{42.2}{65.3}$ & $\frac{49.3}{76.2}$ \\
\hline
\end{tabular}




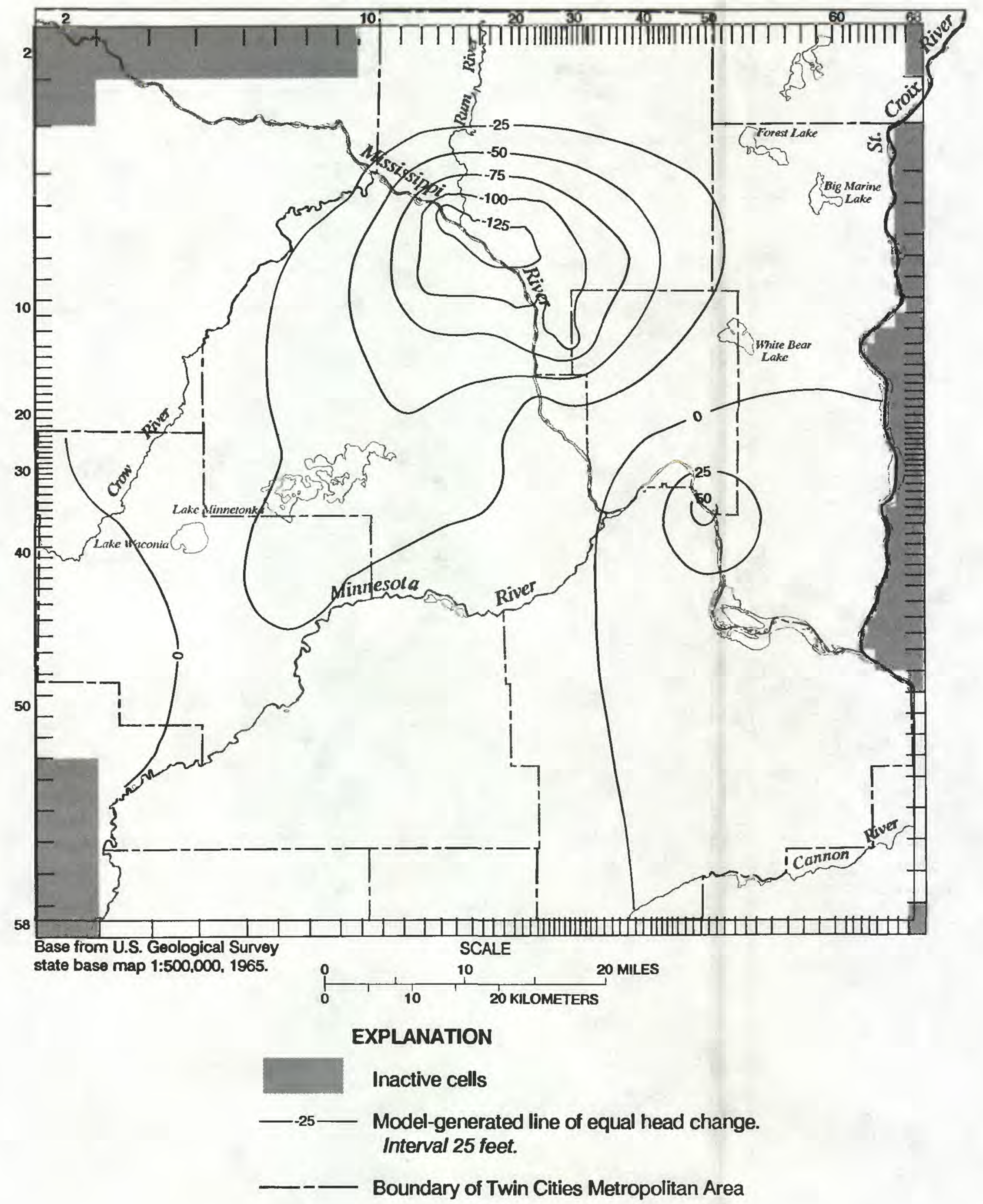

Figure 37a.-Differences between simulated potentiometric surfaces for the calibration period and scenario 1 for model layer 1 (Mount Simon-Hinckley aquifer). 


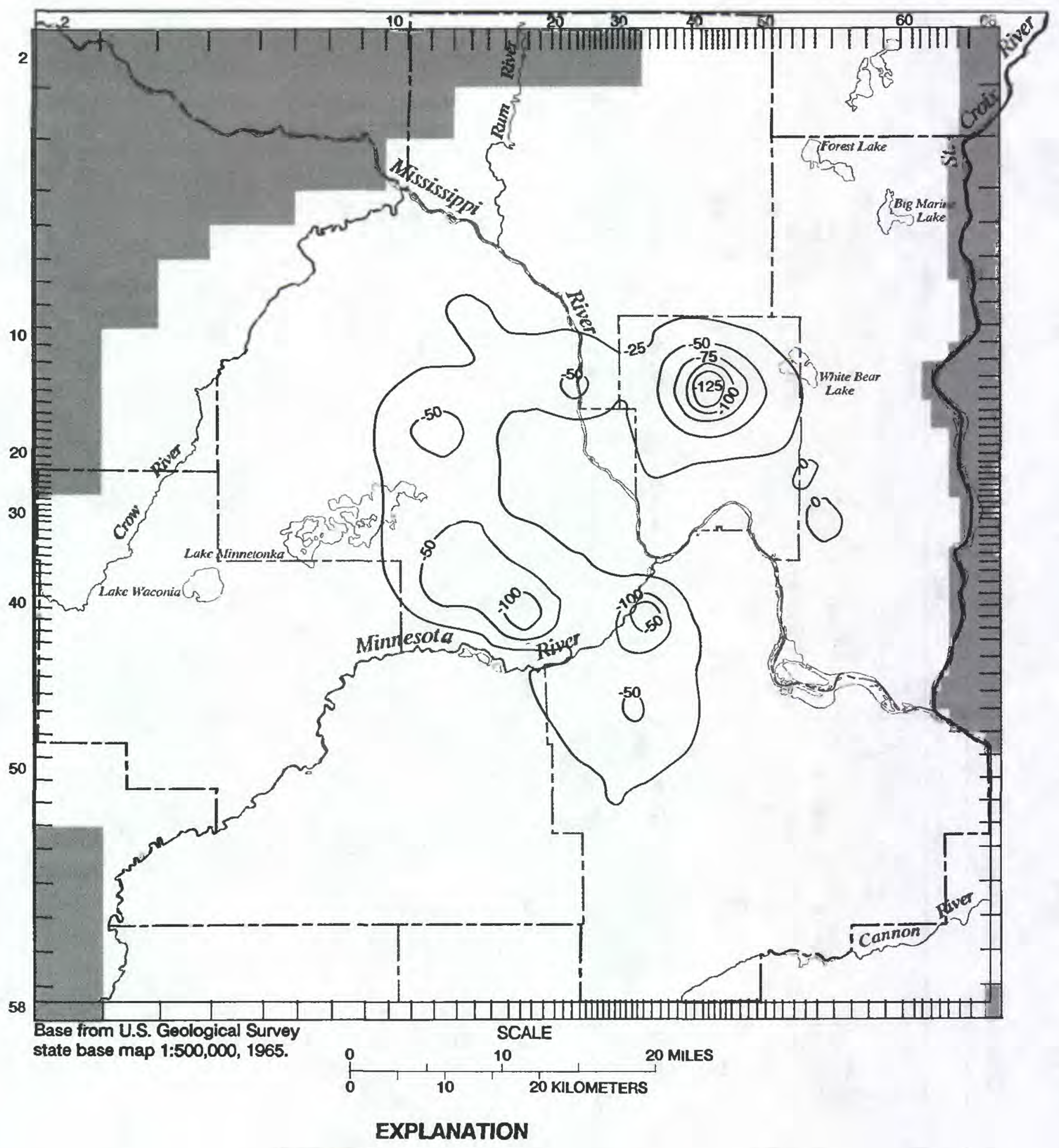

Inactive cells

_-25 - Model-generated line of equal head change. Interval 25 feet.

Boundary of Twin Cities Metropolitan Area

Figure 37b.-Differences between simulated potentiometric surfaces for the calibration period and scenario 1 for model layer $\mathbf{8}$ (Prairie du Chien-Jordan aquifer). 


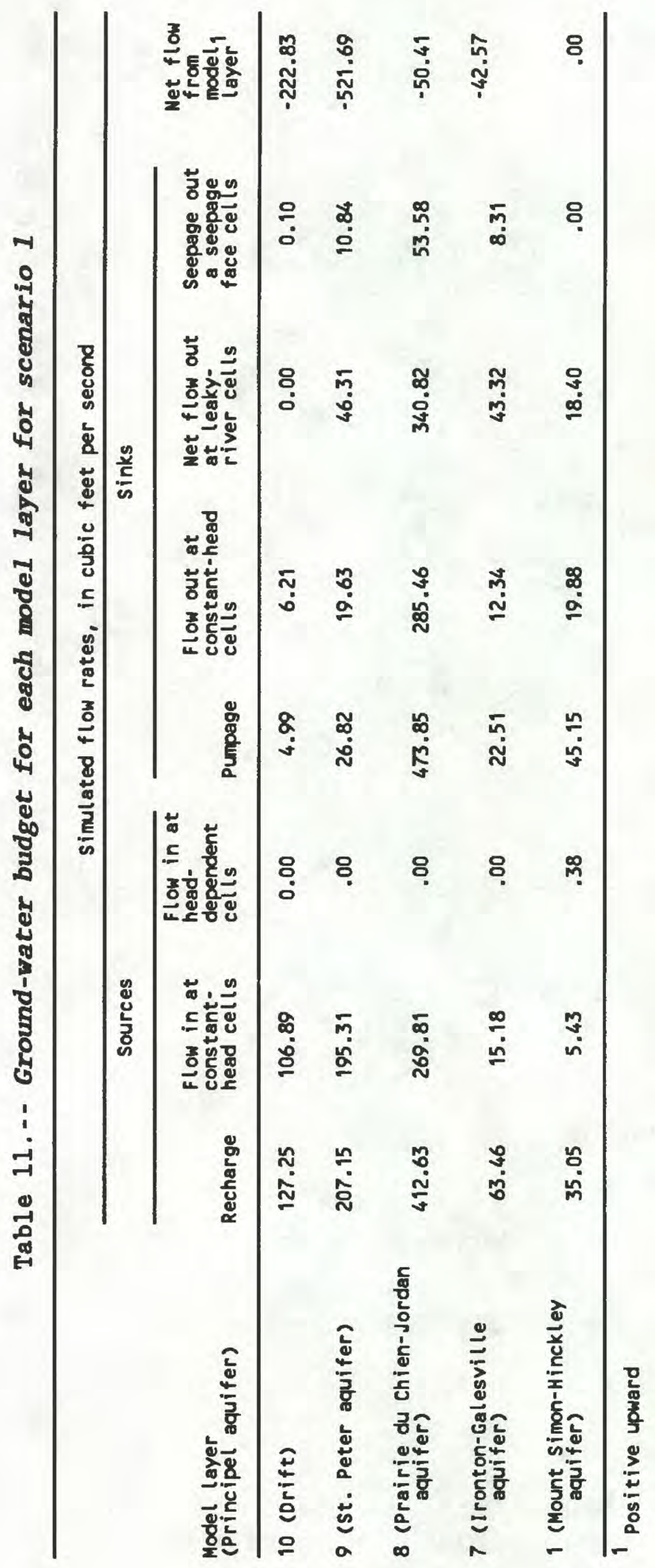


Table 12.--Simulated hydraulic-head differences between the calibration simulation (1970-79) and the four scenarios at calculated cones of depression

[a dash indicates no cone of depression at cell]

\begin{tabular}{|c|c|c|c|c|c|c|}
\hline $\begin{array}{l}\text { Cell } \\
\text { (row, } \\
\text { colum, } \\
\text { layer) }\end{array}$ & $\begin{array}{c}\text { Calibration } \\
\text { simulation } \\
\text { (1970-79) } \\
\text { in feet above } \\
\text { sea level }\end{array}$ & Scenario 1 & $\begin{array}{l}\text { ange, in fee } \\
\text { Scenario } 2\end{array}$ & $\begin{array}{l}\text { from } 1970-79 \text {, } \\
\text { Scenario } 3\end{array}$ & Scenario 4 & Location \\
\hline $6,14,1$ & 801 & -151 & -233 & - & -346 & Anoka \\
\hline $7,17,1$ & 756 & - & - & -342 & - & $\begin{array}{l}\text { Hanover- } \\
\text { Hassen Township }\end{array}$ \\
\hline $9,13,1$ & 781 & - & - & -428 & - & Maple Grove \\
\hline $11,17,1$ & 706 & - & - & -284 & - & Brooklyn Park \\
\hline $28,16,1$ & 678 & -26 & -82 & -107 & -178 & St. Louis Park \\
\hline $33,16,1$ & 687 & -41 & -98 & -116 & -195 & Edina \\
\hline $46,16,1$ & 730 & -26 & -109 & -129 & -194 & Savage \\
\hline $8,19,1$ & 731 & -131 & -224 & - & -355 & Coon Rapids \\
\hline $8,21,1$ & 731 & -131 & -224 & - & -355 & Coon Rapids \\
\hline $9,27,1$ & 713 & -135 & -229 & -247 & -364 & Blaine \\
\hline $12,25,1$ & 669 & -108 & -210 & -217 & -349 & Fridley \\
\hline $13,29,1$ & 692 & -128 & -232 & -221 & -371 & New Brighton \\
\hline $7,7,7$ & 889 & -1 & -2 & -2 & -3 & $\begin{array}{l}\text { Hanover- } \\
\text { Hassen Township }\end{array}$ \\
\hline $6,14,7$ & 814 & 10 & 3 & 11 & -9 & Anoka \\
\hline $11,17,7$ & 816 & - & - & -77 & - & Brooklyn Park \\
\hline $8,26,7$ & 818 & -111 & -161 & -124 & -242 & Blaine \\
\hline $33,31,7$ & 752 & - & -45 & - & - & Minneapolis \\
\hline $35,33,7$ & 750 & -10 & - & - & - & St. Paul \\
\hline $35,29,7$ & 755 & - & - & -39 & - & Minneapolis \\
\hline $9,13,8$ & 870 & -99 & -122 & -49 & -176 & Maple Grove \\
\hline $19,12,8$ & 878 & -86 & -143 & -85 & -198 & Plymouth \\
\hline $36,13,8$ & 819 & -88 & -129 & -88 & -182 & Minnetonka \\
\hline $39,12,8$ & 811 & -103 & -177 & -103 & -237 & Eden Prairio \\
\hline $42,17,8$ & 745 & -121 & -283 & -121 & -379 & Bloomington \\
\hline $23,23,8$ & 716 & -27 & -90 & -27 & -132 & Minneapolis \\
\hline $24,35,8$ & 743 & -59 & -135 & -59 & -182 & St. Paul \\
\hline $27,33,8$ & 682 & -3 & -36 & -4 & -64 & St. Paul \\
\hline 37.23 .8 & 730 & -26 & -46 & -27 & -84 & Richfield \\
\hline $28,33,8$ & 768 & -1 & - & -1 & - & St. Paul \\
\hline $42,34,8$ & 761 & -155 & -254 & -155 & -343 & Burnsville \\
\hline $14,42,8$ & 852 & -256 & -425 & -256 & -581 & Vadnais Heights \\
\hline $15,41,8$ & 843 & -203 & -359 & -206 & -493 & $\begin{array}{l}\text { Vadnais Heights } \\
\text { (St. Paul Water Utility) }\end{array}$ \\
\hline $26,45,8$ & 681 & 6 & -18 & 6 & -61 & St. Paul \\
\hline
\end{tabular}


Table 12.--Simulated hydraulic-head differences between the calibration simulation (1970-79) and the

four scenarios at calculated cones of depression--Continued

\begin{tabular}{|c|c|c|c|c|c|c|}
\hline $\begin{array}{l}\text { Cell } \\
\text { (row, } \\
\text { column, } \\
\text { layer) }\end{array}$ & $\begin{array}{c}\text { Calibration } \\
\text { simulation } \\
\text { (1970-79) } \\
\text { in feet above } \\
\text { sea level }\end{array}$ & Scenario 1 & $\begin{array}{l}\text { ange, in feet } \\
\text { Scenario } 2\end{array}$ & $\begin{array}{l}\text { from } 1970-79 \\
\text { Scenario } 3\end{array}$ & Scenario 4 & Location \\
\hline $29,42,8$ & 713 & -6 & -28 & -7 & -56 & St. Paul \\
\hline $32,40,8$ & 724 & -13 & -46 & -13 & -66 & St. Paul \\
\hline $32,47,6$ & 732 & -14 & -28 & -15 & -54 & st. Paul \\
\hline $36,46,6$ & 733 & -7 & -16 & -7 & -35 & South St. Paul \\
\hline $44,52,6$ & 666 & -9 & -11 & -9 & -14 & Nininger \\
\hline $33,55,8$ & 833 & $-4-7$ & -61 & -48 & -115 & Woodbury \\
\hline $45,56,8$ & 667 & -8 & -12 & -8 & -32 & Cottage Grove \\
\hline $10,14,9$ & 660 & -47 & -74 & -46 & -110 & Osseo \\
\hline $11,17,9$ & 647 & -20 & - & - & - & Brooklyn Park \\
\hline $38,15,9$ & 809 & - & -70 & - & -103 & Edina \\
\hline $38,15,9$ & 796 & - & - & - & -92 & Edina \\
\hline $40,13,9$ & 619 & - & -67 & - & -93 & Eden Prairie \\
\hline $14,22,9$ & 618 & -106 & -247 & -107 & -375 & $\begin{array}{l}\text { Fridley } \\
\text { (Minneapolis Water Works) }\end{array}$ \\
\hline $24,35,9$ & 757 & - & -65 & - & -97 & St. Paul \\
\hline $37,34,9$ & 691 & -2 & -3 & -2 & -3 & $\begin{array}{l}\text { Twin Cities } \\
\text { International Airport }\end{array}$ \\
\hline $40,19,9$ & 787 & - & - & - & -62 & Bloomington \\
\hline $41,31,9$ & 699 & -8 & -11 & -8 & - & $\begin{array}{l}\text { Minnesota River between } \\
\text { Bloomington and Burnsville }\end{array}$ \\
\hline $42,33,9$ & 753 & - & - & - & -67 & Burnsville \\
\hline $14,43,9$ & 666 & -72 & -126 & -72 & -176 & St. Paul \\
\hline $23,53,9$ & 649 & -23 & -40 & -24 & -54 & Oakdale \\
\hline $33,47,9$ & 709 & -3 & -7 & -3 & -13 & Pig's Eye \\
\hline $33,49,9$ & 756 & -49 & -51 & -49 & -56 & Pig's Eye \\
\hline $19,57,9$ & 695 & -6 & -11 & -6 & -17 & Lake Elmo \\
\hline $30,55,9$ & 812 & -19 & -34 & -20 & -50 & Woodbury \\
\hline $19,17,10$ & 648 & - & - & - & -46 & $\begin{array}{l}\text { Golden Velley/Crystal/ } \\
\text { Robbinsdale }\end{array}$ \\
\hline $35,17,10$ & 617 & -27 & -49 & -27 & -76 & Edina \\
\hline $11,25,10$ & 830 & -36 & -64 & -36 & -137 & Fridley \\
\hline $14,23,10$ & 832 & - & -66 & - & -141 & $\begin{array}{l}\text { Fridley } \\
\text { (Minneapolis Water Works) }\end{array}$ \\
\hline $20,38,10$ & 856 & - & -26 & - & -41 & Roseville \\
\hline $15,46,10$ & 828 & - & 9 & - & -13 & Vadnais Heights-Maplowood \\
\hline
\end{tabular}


Table 12.--Simulated hydraulic-head differences between the calibration simulation (1970-79) and the

four scenarios at calculated cones of depression--Continued

\begin{tabular}{|c|c|c|c|c|c|c|}
\hline $\begin{array}{l}\text { Cal1 } \\
\text { (row, } \\
\text { colum, } \\
\text { layar) }\end{array}$ & $\begin{array}{l}\text { Calibration } \\
\text { simulation } \\
\text { (1970-79) } \\
\text { in faat above } \\
\text { sea level }\end{array}$ & Scenario 1 & $\begin{array}{c}\text { Changa, in faa } \\
\text { Scenario } 2\end{array}$ & $\begin{array}{l}\text { from } 1970-79 \\
\text { Scenario } 3\end{array}$ & Scenario 4 & Location \\
\hline $16,49,10$ & 899 & - & - & - & -71 & White Bear Lake-Maplewood \\
\hline $18,48,10$ & 875 & -21 & - & -21 & - & Maplewood \\
\hline $15,50,10$ & 910 & -39 & -51 & -39 & - & White Bear Laka \\
\hline $15,53,10$ & 926 & -18 & -31 & -18 & -46 & Whita Baar Laka \\
\hline $20,38,10$ & 858 & - & -26 & - & -41 & Roseville \\
\hline $23,42,10$ & 832 & -14 & -32 & -14 & -51 & St. Paul \\
\hline $28,46,10$ & 778 & -8 & -22 & -8 & -41 & St. Paul \\
\hline
\end{tabular}




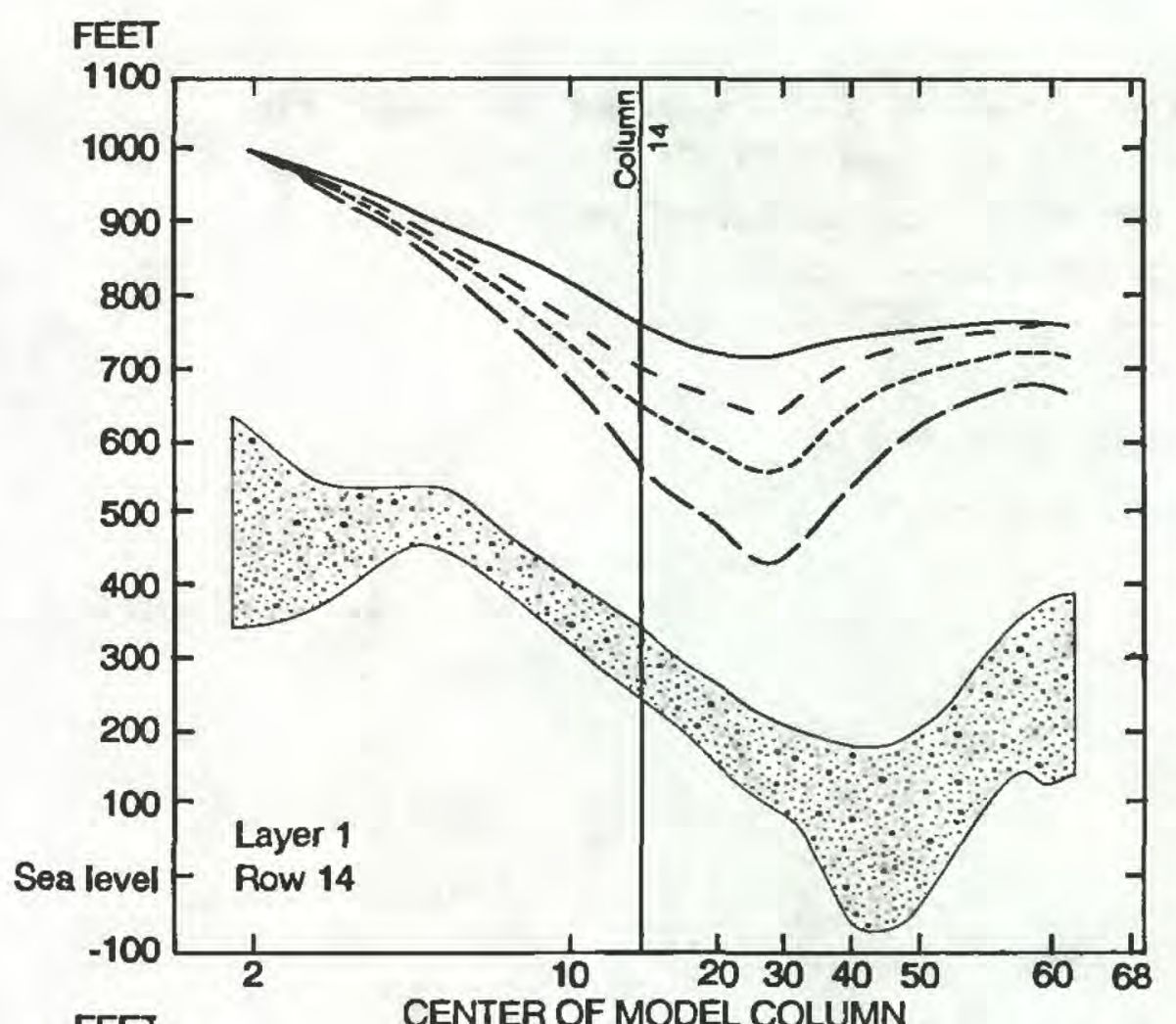

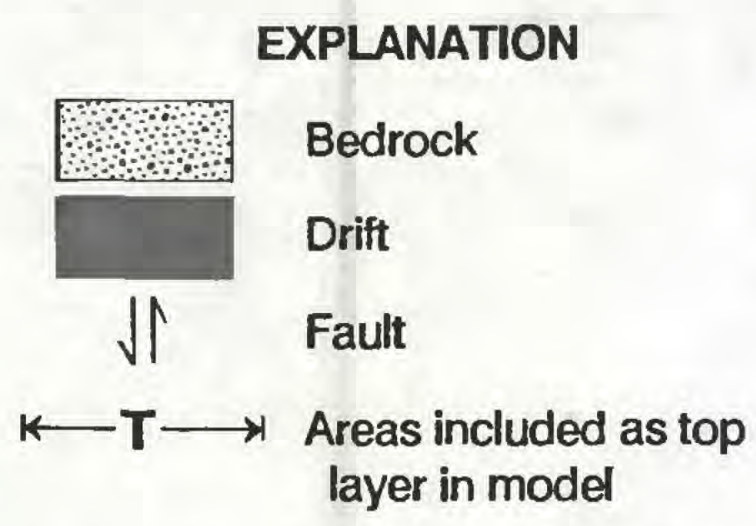

Simulated heads for:
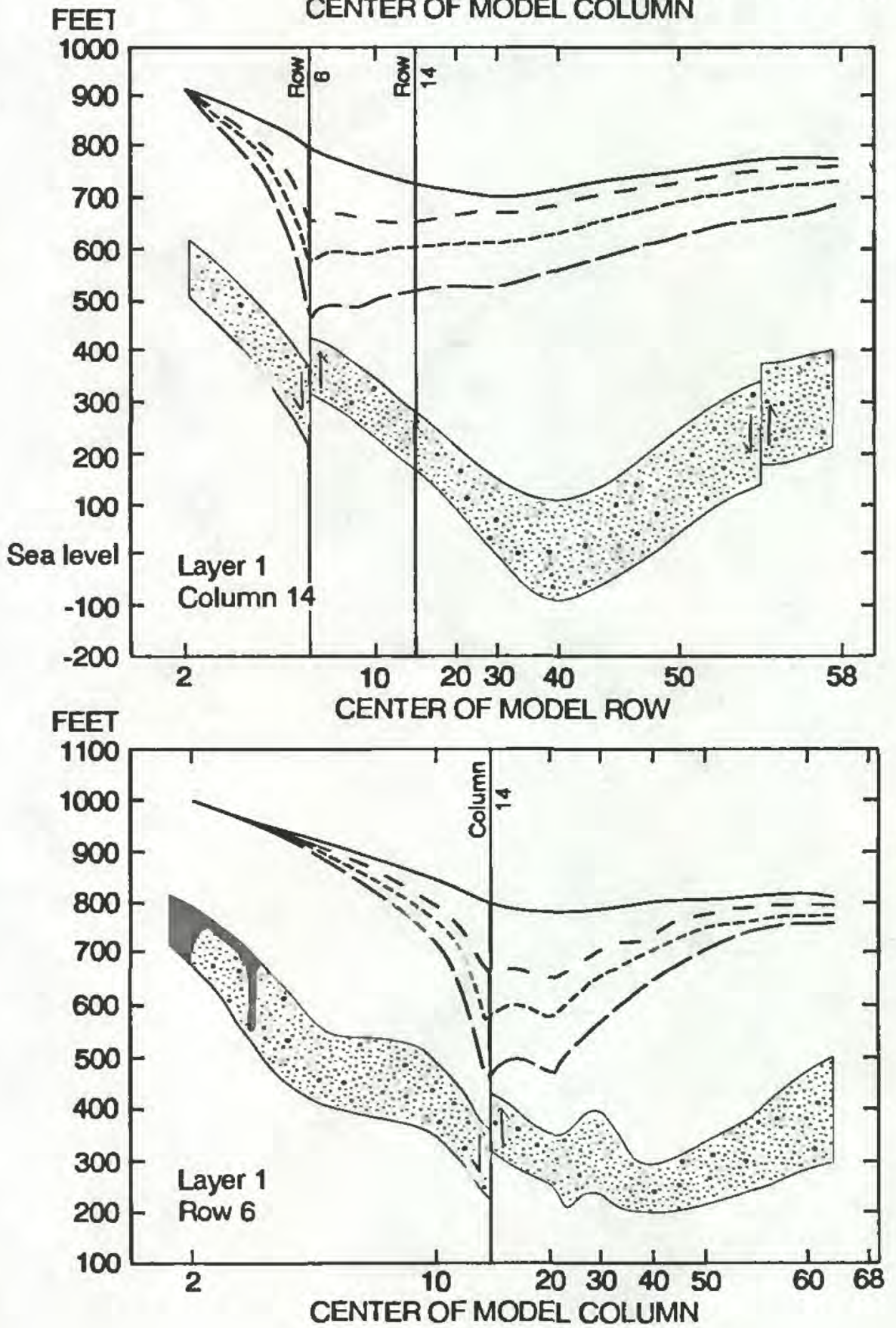

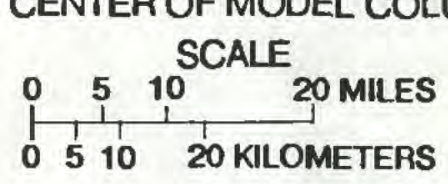

Calibration period, 1970-79

- - - - - Scenario 1

Scenario 2

Scenario 4

Vertical scale is greatly exaggerated Datum is sea level

Figure 38a.-Simulated potentiometric surfaces through selected model rows and columns for layer 1 (Mount Simon-Hinckley aquifer). 

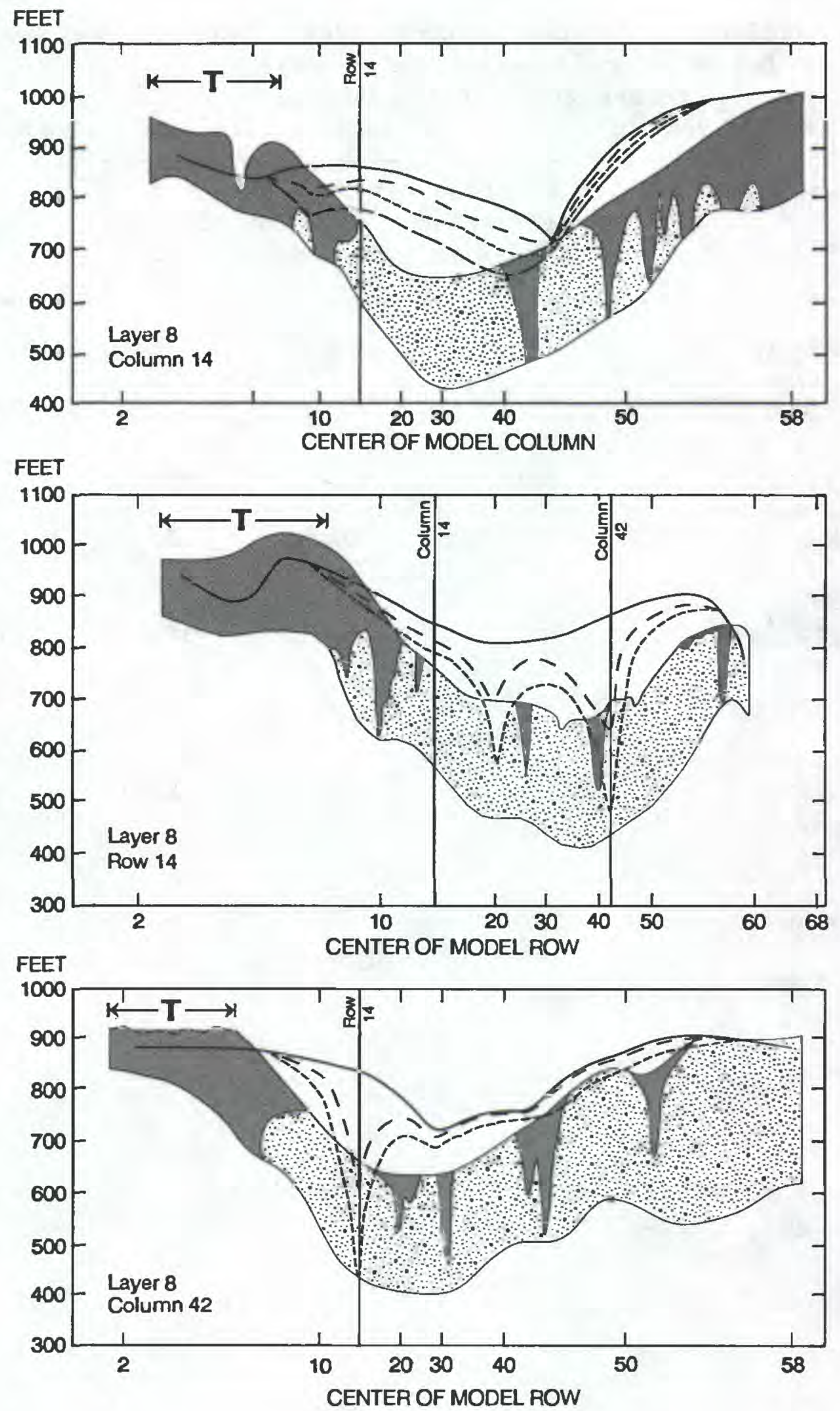

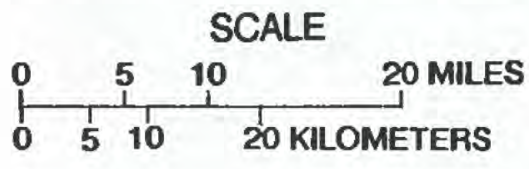

Figure 38b.-Simulated potentiometric surfaces through selected model rows and columns for layer 8 (Prairie du Chien-Jordan aquifer). 
Table 13.--Calculated effective recharge, river leakage, and seepage for model calibration and scenarios of

\section{future ground-water pumpage}

[in/yr, inches per year; $\mathrm{ft}^{3} / \mathrm{s}$, cubic feet per second; a dash indicates no value]

\begin{tabular}{|c|c|c|c|c|}
\hline Model simulation & $\begin{array}{l}\text { Simulation } \\
\text { calibration } \\
(1970-79)\end{array}$ & $\begin{array}{l}\text { Scenarios } \\
1 \text { and } 3\end{array}$ & $\begin{array}{l}\text { Scenario } \\
2\end{array}$ & $\begin{array}{l}\text { Scenario } \\
4\end{array}$ \\
\hline $\begin{array}{l}\text { Effective recharge (in/yr)... } \\
\text { Percent increase over }\end{array}$ & 4.32 & 5.09 & 5.70 & 6.40 \\
\hline calibration value......... & - & 17 & 32 & 48 \\
\hline $\begin{array}{l}\text { River leakage }\left(\mathrm{ft}^{3} / \mathrm{s}\right) \ldots \ldots \ldots \\
\text { Percent decrease over }\end{array}$ & 622 & 535 & 469 & 392 \\
\hline calibration value......... & - & 14 & 25 & 37 \\
\hline $\begin{array}{l}\text { River leakage from } \\
\text { major streams }\left(\mathrm{ft}^{3 /} \mathrm{s}\right) \ldots \ldots \\
\text { Percent decrease over }\end{array}$ & 528 & 444 & 380 & 308 \\
\hline calibration value......... & - & 16 & 28 & 42 \\
\hline $\begin{array}{l}\text { River leakage from } \\
\text { minor streams }\left(\mathrm{ft}^{3} / \mathrm{s}\right) \ldots \ldots \\
\text { Percent decrease over }\end{array}$ & 93.7 & 90.5 & 88.1 & 84.5 \\
\hline calibration value......... & - & 3.4 & 6.0 & 9.8 \\
\hline $\begin{aligned} & \text { Seepage from seepage } \\
& \text { faces }\left(\mathrm{ft}^{3} / \mathrm{s}\right) \ldots \ldots \ldots \ldots \ldots \\
& \text { Percent decrease over }\end{aligned}$ & 74.2 & 72.5 & 70.6 & 68.0 \\
\hline calibration value......... & - & 2.3 & 4.9 & 8.4 \\
\hline
\end{tabular}




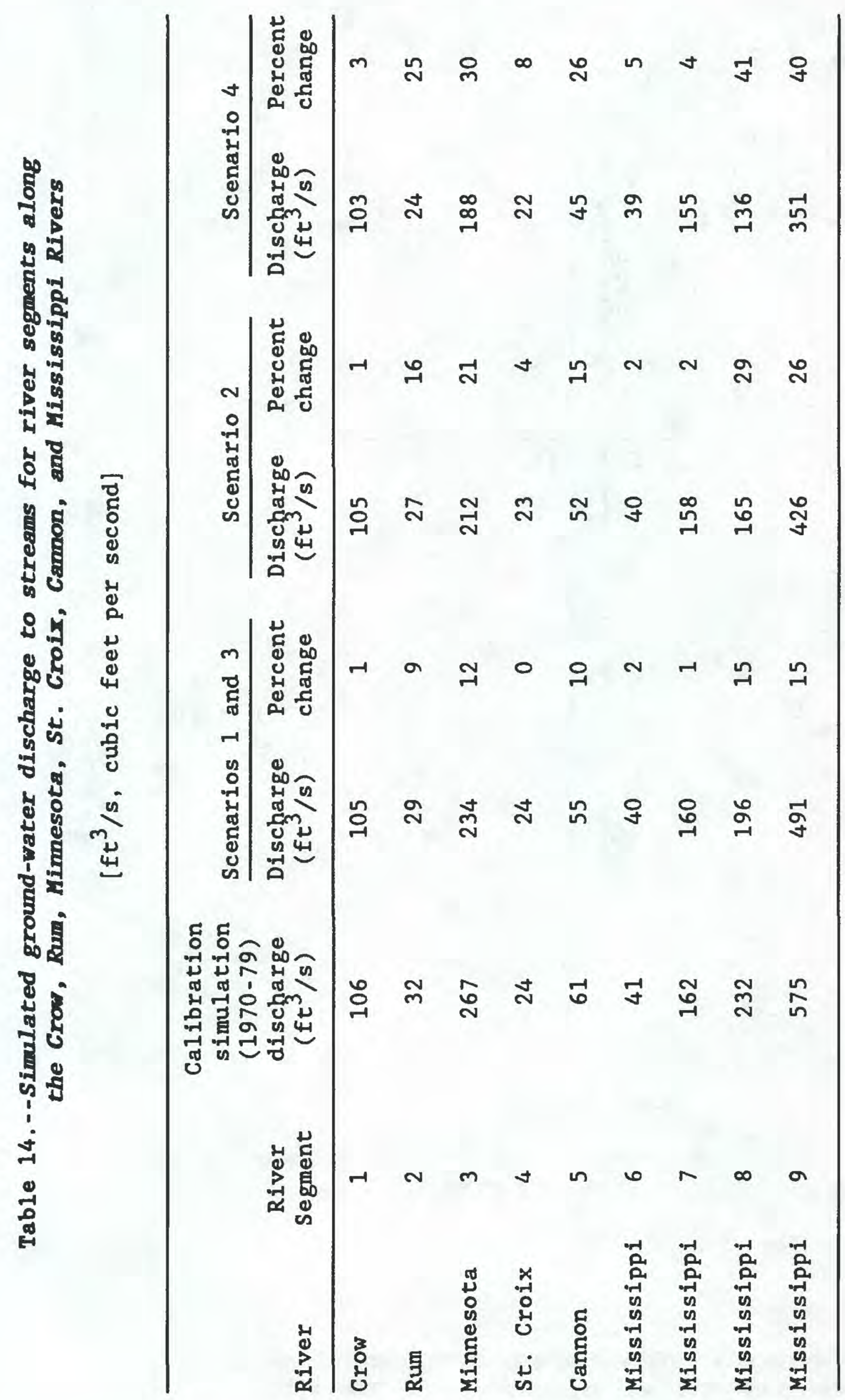



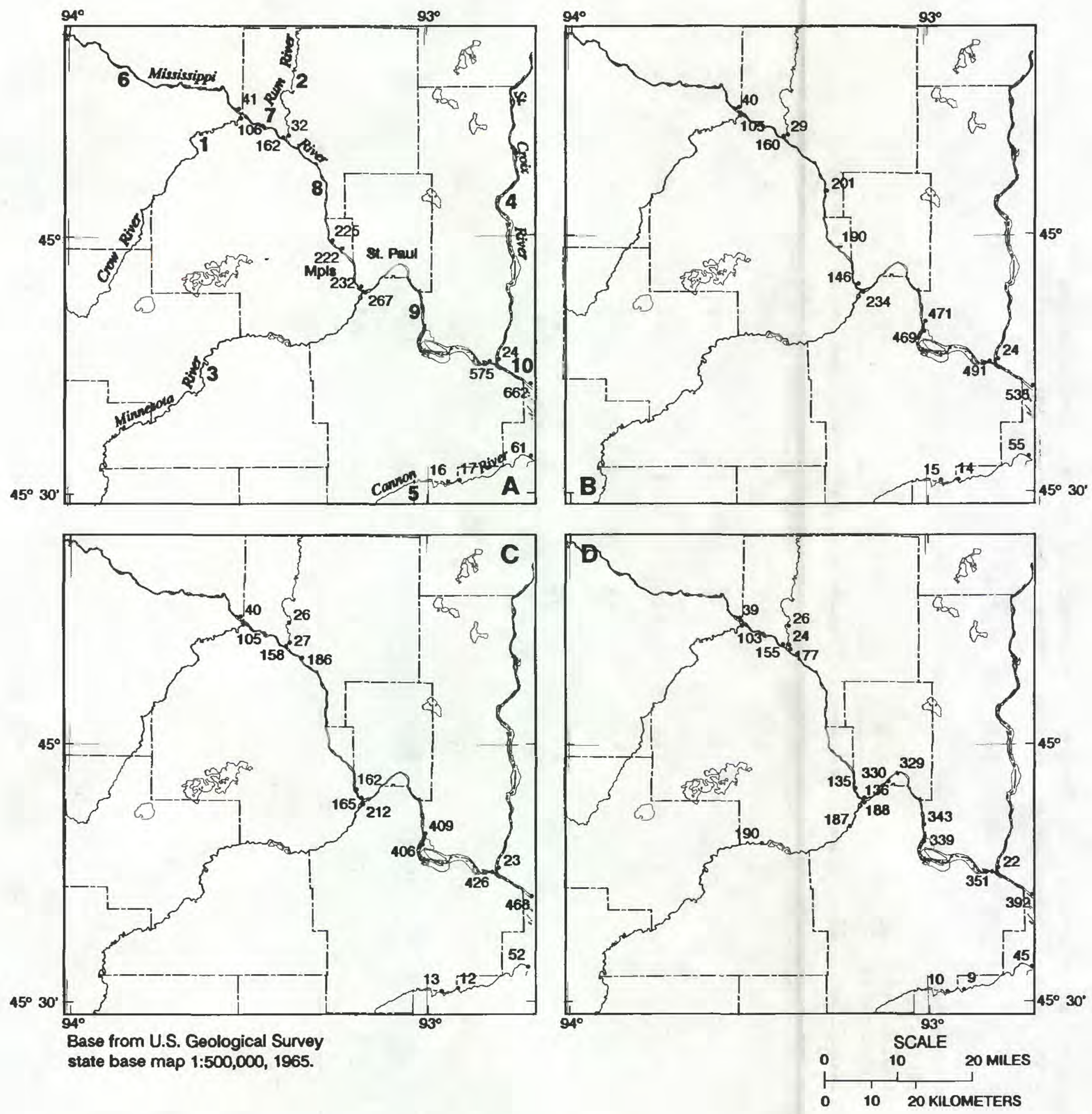

\section{EXPLANATION}

.106 Model-calculated cumulative discharge in cubic feet per second

9 River segment

Figure 39.-Model-calculated cumulative discharge from aquifers to major streams under steady-state conditions for (A) the 1970's (calibration period),

(B) scenarios 1 and 3, (C) scenario 2, and (D) scenario 4 


\section{Scenario 2}

The scenario was run under conditions of projected population and economic change, given no adverse climatic conditions. Increases in ground-water pumpage from the Prairie du Chien-Jordan aquifer and the drift were projected to be about $290 \mathrm{Mgal} / \mathrm{d}$ (about 90 percent) out of the total projected increase of about $310 \mathrm{Mgal} / \mathrm{d}$. In areas underlain by the Prairie du Chien-Jordan aquifer (layer 8), projected increases in ground-water withdrawals from that aquifer totaled about $245 \mathrm{Mgal} / \mathrm{d}$. Increases of about $40 \mathrm{Mgal} / \mathrm{d}$ were projected from aquifers in the drift. Communities that presently obtain their water supplies from the Mount Simon-Hinckley aquifer were projected to increase their withdrawals by $15 \mathrm{Mgal} / \mathrm{d}$. The total ground-water pumpage for each aquifer is shown in table 10. The ground-water budget for each model layer is 1 isted in table 15 .

Differences between these simulated potentiometric surfaces and 1970-79 (calibration) potentiometric surfaces for layers 8 and 1 are shown in figures $40 \mathrm{a}$ and $40 \mathrm{~b}$, respectively. Table 12 lists both the maximum model-calculated head change from the calibration simulation as well as a detailed listing of all apparent cones of depression simulated by the model.

The simulation indicated that for scenario 2 the maximum differences from the model-calculated heads for the 1970-79 steady-state run occur in model layer 8 at the site of the St. Paul Water Utility at Vadnais Lake. Most simulated cones of depression ( $f i g .38$, table 12) are minor. The five largest ones correspond to areas around the St. Paul Water Utility at Vadnais Lake, Bloomington, Burnsville, Anoka, and New Brighton.

The simulation illustrates the effect of greatly increased withdrawals that were first shown in scenario 1. The differences from the 1970-79 (calibration) period show an increase in the effective recharge rate from 4.32 in/yr for 1970-79 to $5.70 \mathrm{in} / \mathrm{yr}$, a 32 -percent increase (table 13).

The location and major differences in leakage to the major rivers between the 1970-79 (calibration) period and this simulation occur along river segments $3,8,9$, and 10 (fig. 39, table 14). In terms of absolute and percent differences, segments $3,8,9$, and $10 \mathrm{had} 55,67,149$, and $194 \mathrm{ft} / \mathrm{s}$ and 21 , 29,26 , and 29 percent smaller contribution to river flow from the aquifer system, respectively. Simulated reversals of flow between river and aquifer extended north along the Mississippi River from about Ford Dam upstream past Minneapolis and St. Anthony Falls to the southern boundary of Coon Rapids . Reversals in flow were projected along the Mississippi River in the vicinity of Nininger and along the Cannon River near Byllesby Reservoir. 


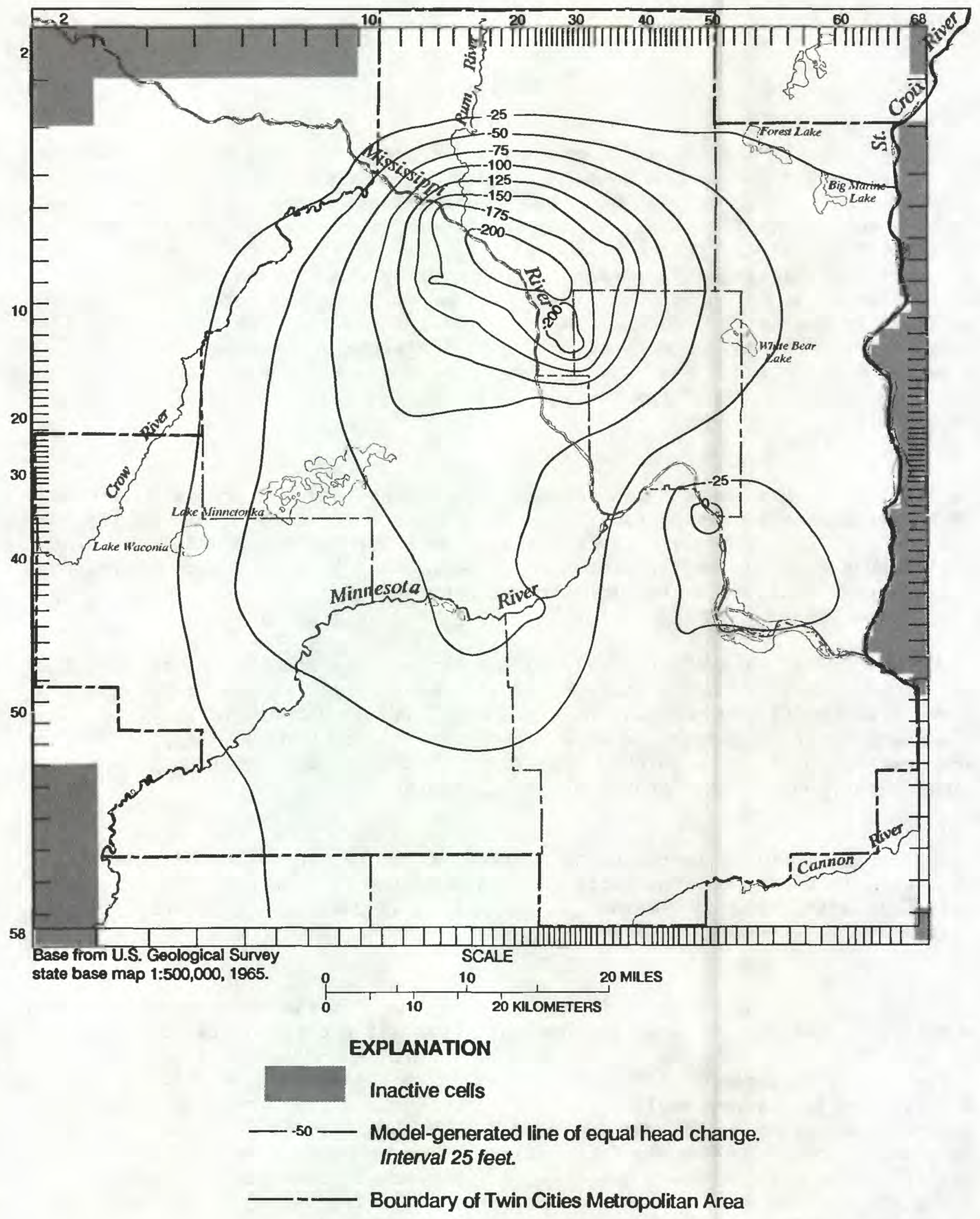

Figure 40a.-Differences between simulated potentiometric surfaces for the calibration period and scenario 2 for model layer 1 (Mount Simon-Hinckley aquifer). 


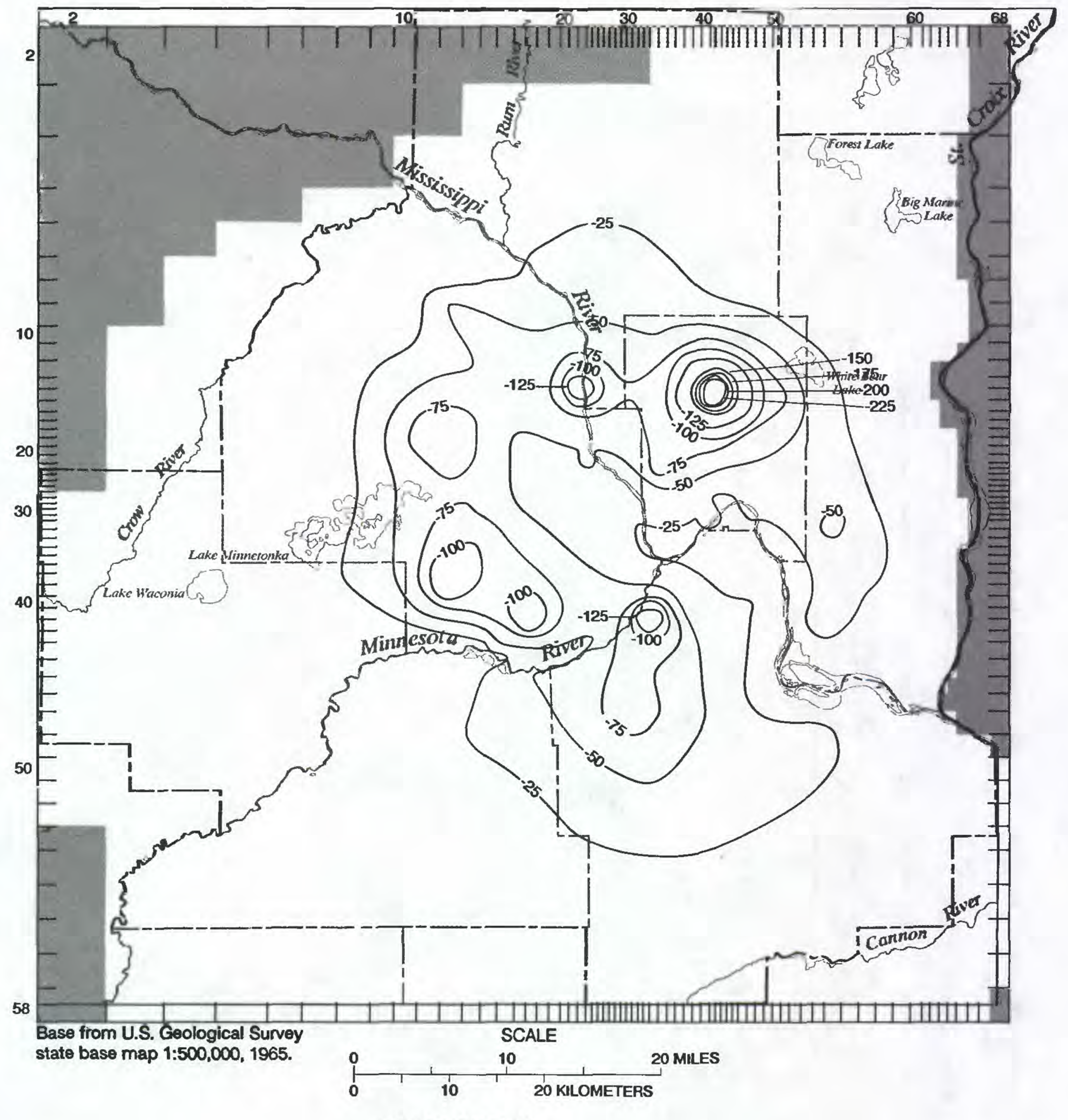

EXPLANATION

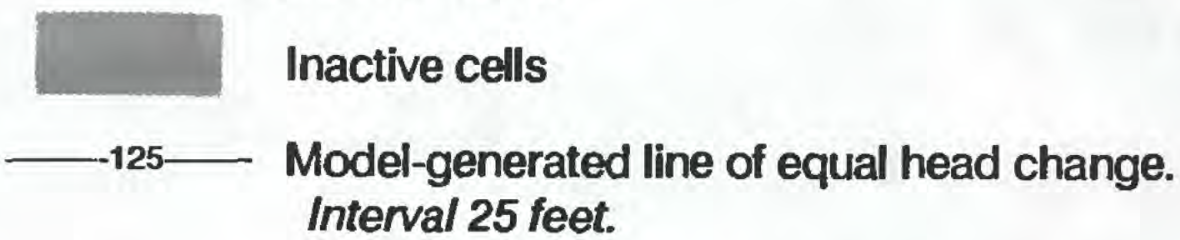

Boundary of Twin Cities Metropolitan Area

Figure 40b.-Differences between simulated potentiometric surfaces for the calibration period and scenario 2 for model layer 8 (Prairie du Chien-Jordan aquifer). 


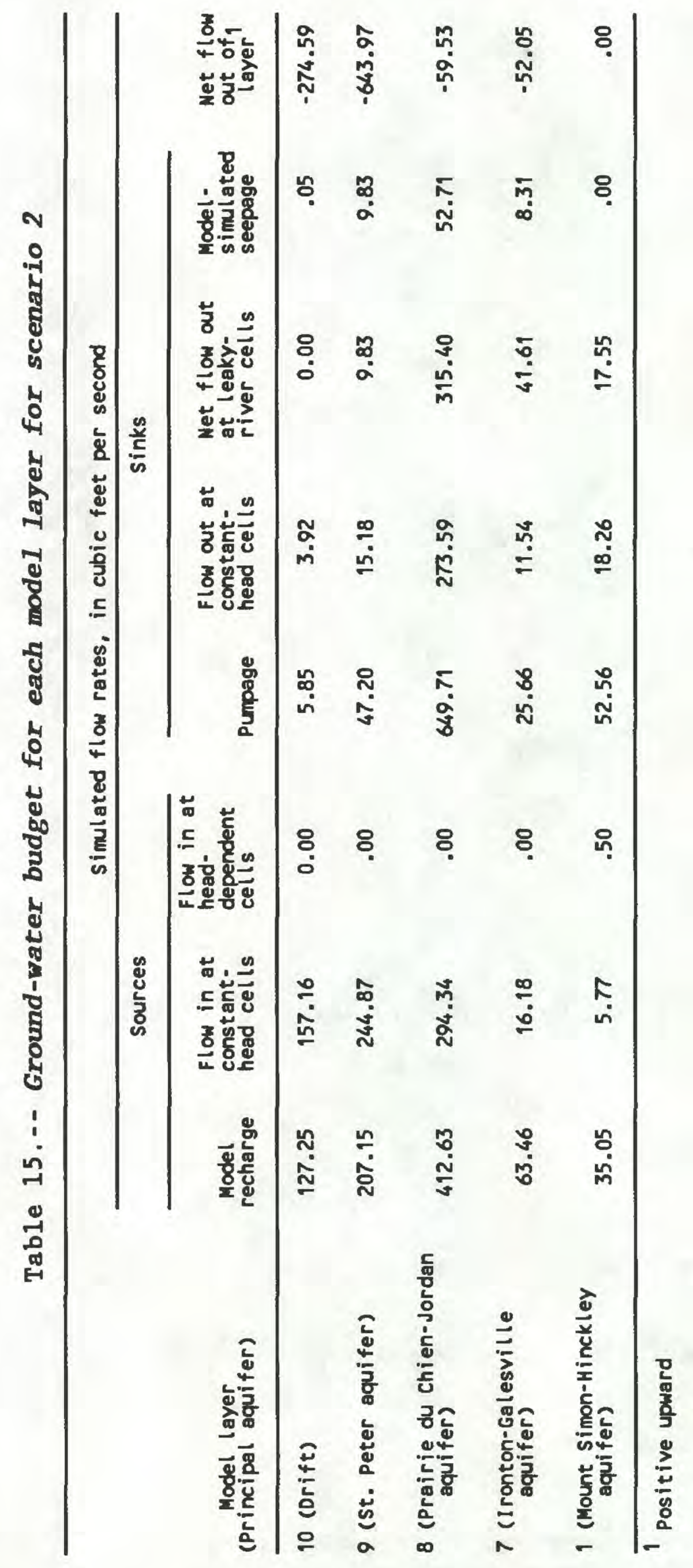




\section{Scenario 3}

While major increases in ground-water pumpage for scenario 1 from the period 1970-79 (calibration) are projected primarily from the Prairie du Chien-Jordan aquifer and aquifers in the drift, supplies for future groundwater withdrawals from aquifers in the drift may be inadequate. The projected amount of increase is about $160 \mathrm{Mgal} / \mathrm{d}$ (about 90 percent) out of a total of about $175 \mathrm{Mgal} / \mathrm{d}$. In areas underlain by the Prairie du Chien-Jordan aquifer, ground-water withdrawals were projected to come primarily from that aquifer. In communities that presently obtain their ground water from the Mount SimonHinckley aquifer and do not overlie the Prairie du Chien-Jordan aquifer, some ground-water withdrawals were simulated as coming from the Mount SimonHinckley aquifer instead of the drift. This was simulated by shifting withdrawals of about $13 \mathrm{Mgal} / \mathrm{d}$ from layers 8 and 9 (scenario 1) to layer 1 in the model (scenario 3). This maximized the simulated pumping effects in the Mount Simon-Hinckley aquifer in the event that sufficient ground water is not available from aquifers in the drift. The greatest projected increase in groundwater withdrawals (about $135 \mathrm{Mgal} / \mathrm{d}$ ) was from the Prairie du Chien-Jordan aquifer. The next largest projected increase was from the Mount Simon-Hinckley aquifer (about $25 \mathrm{Mgal} / \mathrm{d}$ ). Table 16 lists the ground-water budget for each model layer for this scenario.

Differences between the simulated potentiometric surfaces and 1970-79 (calibration) potentiometric surfaces for layers 8 and 1 are shown in figures $41 \mathrm{a}$ and $41 \mathrm{~b}$, respectively. Table 12 lists both the maximum change from the calibration simulation as well as a detailed listing of all apparent cones of depression simulated by the model.

The maximum model-calculated head differences from the model-calculated heads for the 1970-79 (calibration) steady-state simulation were in layer 1 in the Maple Grove area. Most simulated cones of depression (fig. 38, table 12) are minor. The five largest ones simulated correspond to areas around Maple Grove, Andover, Brooklyn Center, Blaine, and the St. Paul Water Utility.

\section{Scenario 4}

Major increases in ground-water pumpage from the 1970-79 (calibration) period were simulated primarily from the Prairie du Chien-Jordan and drift aquifers (table 10). The scenario was run under conditions of projected population and economic change similar to scenario 2 , but assuming drought conditions. Drought conditions were defined by the fifth percentile of precipitation and the 95 percentile of temperature. Increased withdrawals from the Prairie du Chien-Jordan aquifer and the drift were projected to be about $425 \mathrm{Mgal} / \mathrm{d}$ (about 90 percent) out of the total projected increase of about 470 Mgal/d. In areas underlain by the Prairie du Chien-Jordan aquifer, and simulated in layer 8 , projected increases in ground-water withdrawals totaled about $365 \mathrm{Mgal} / \mathrm{d}$. Projected increases of about $60 \mathrm{Mgal} / \mathrm{d}$ were simulated from the drift aquifer. Communities which presently obtain their water supplies from the Mount Simon-Hinckley aquifer were projected to increase their withdrawals by $30 \mathrm{Mgal} / \mathrm{d}$. The ground-water budget for each model layer for this scenario is listed in table 17 . 


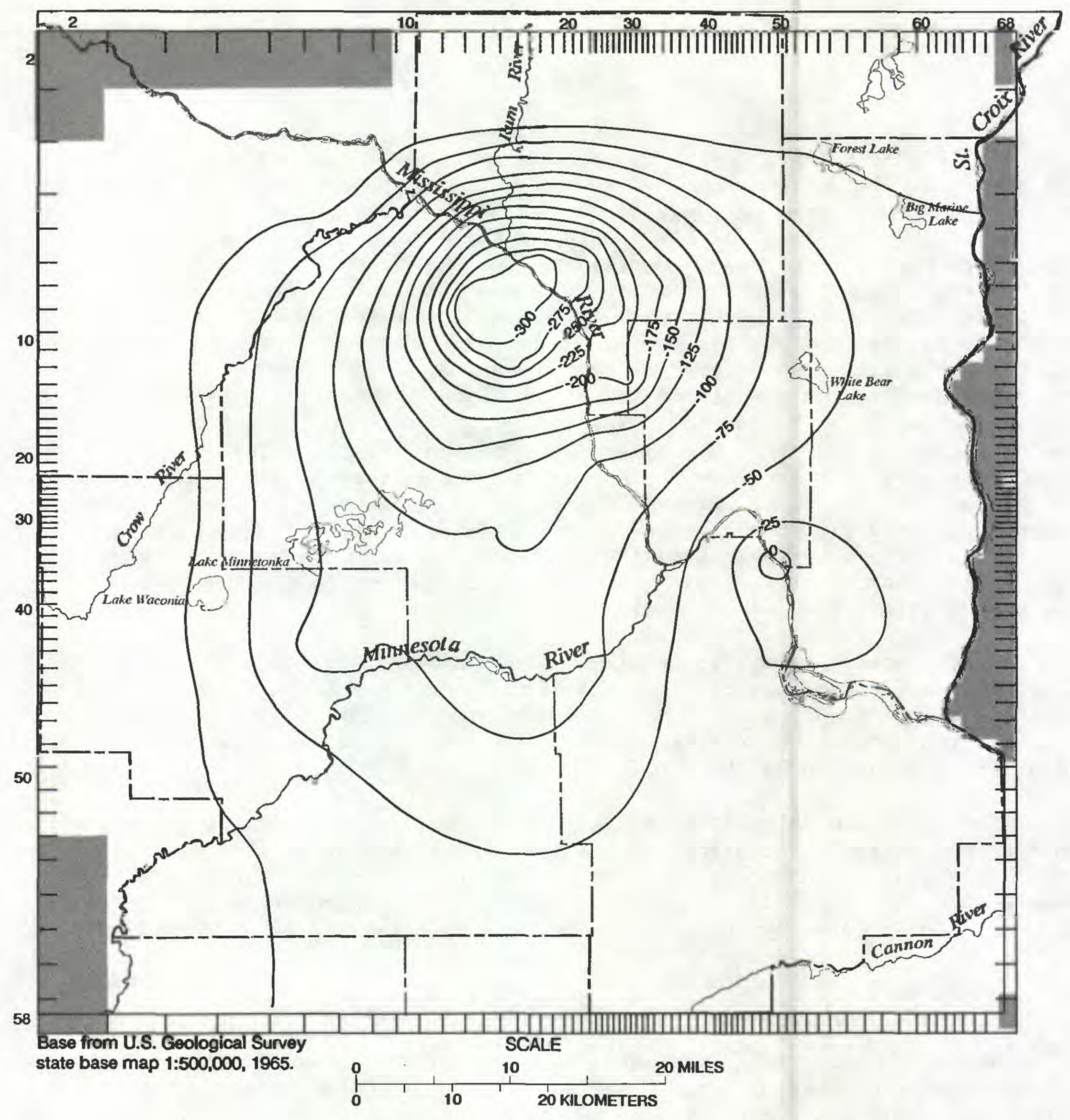

EXPLANATION

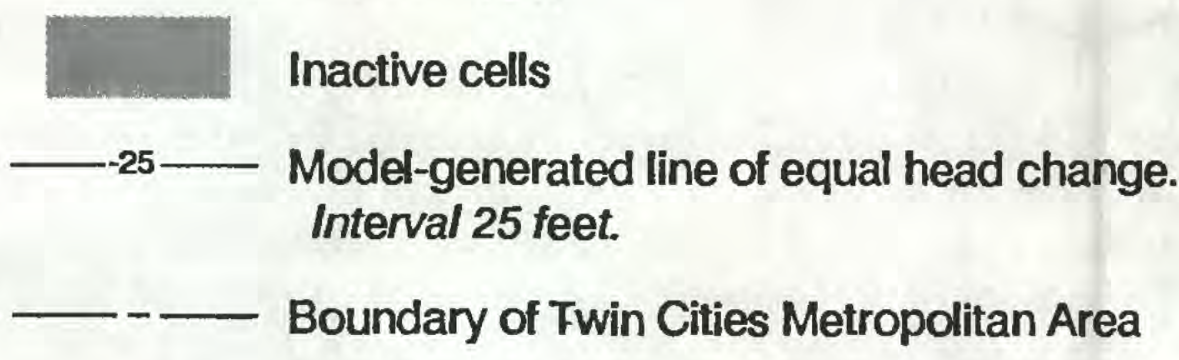

Figure 41a.-Differences between simulated potentiometric surfaces for the calibration period and scenario 3 for model layer 1 (Mount Simon-Hinckley aquifer). 


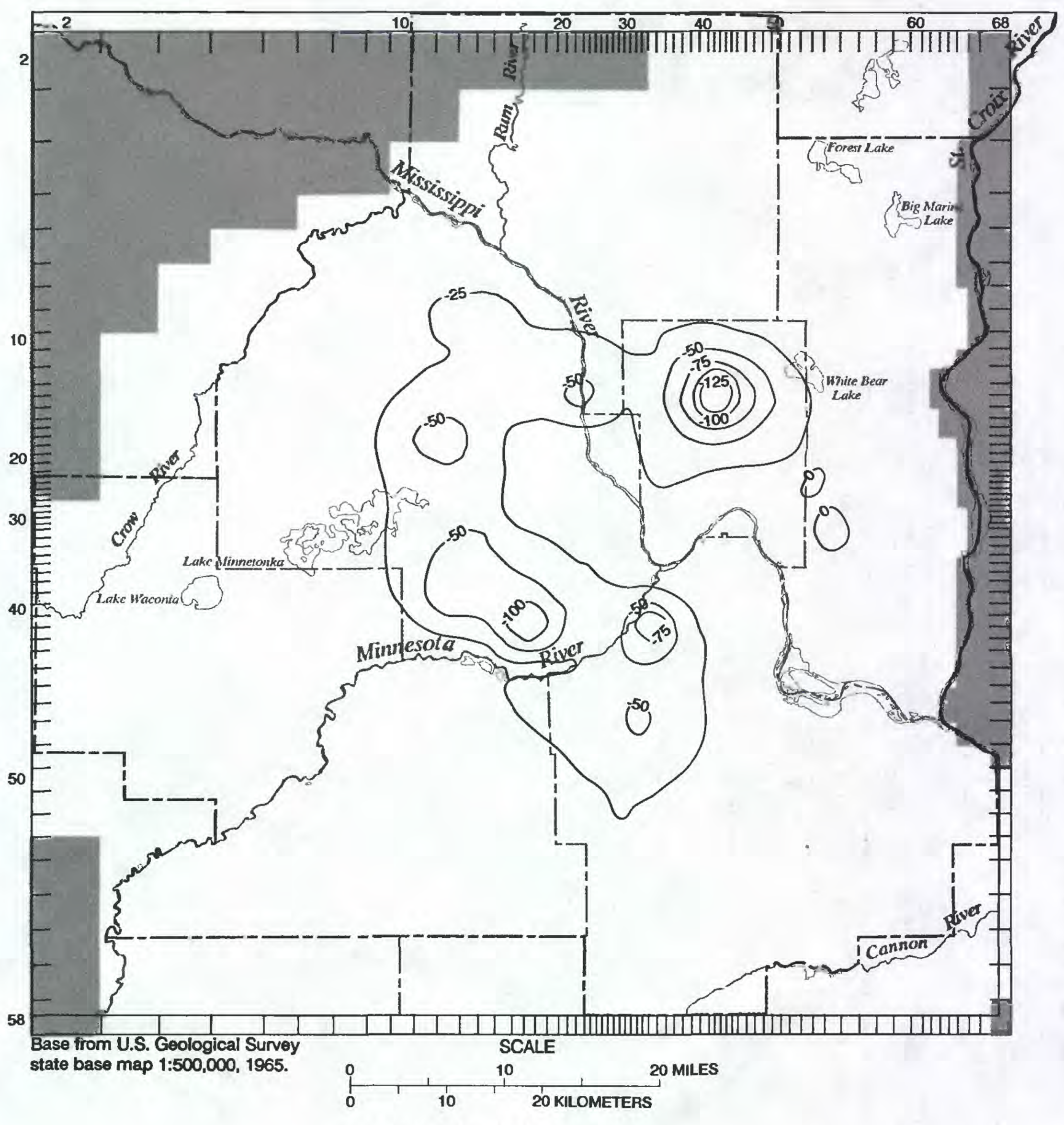

EXPLANATION

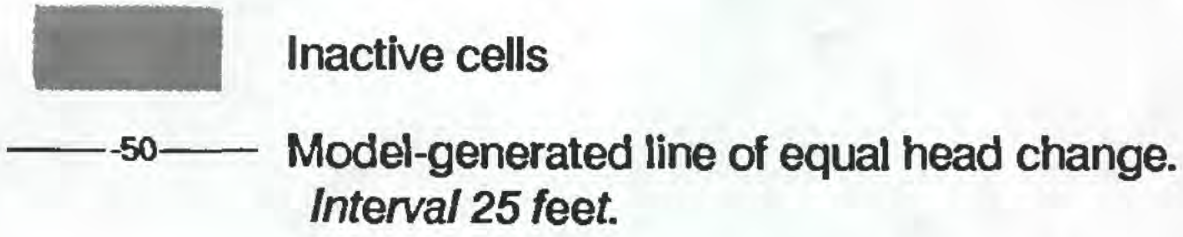

Boundary of Twin Cities Metropolitan Area

Figure 41b.--Differences between simulated potentiometric surfaces for the calibration period and scenario 3 for model layer 8 (Prairie du Chien-Jordan aquifer). 


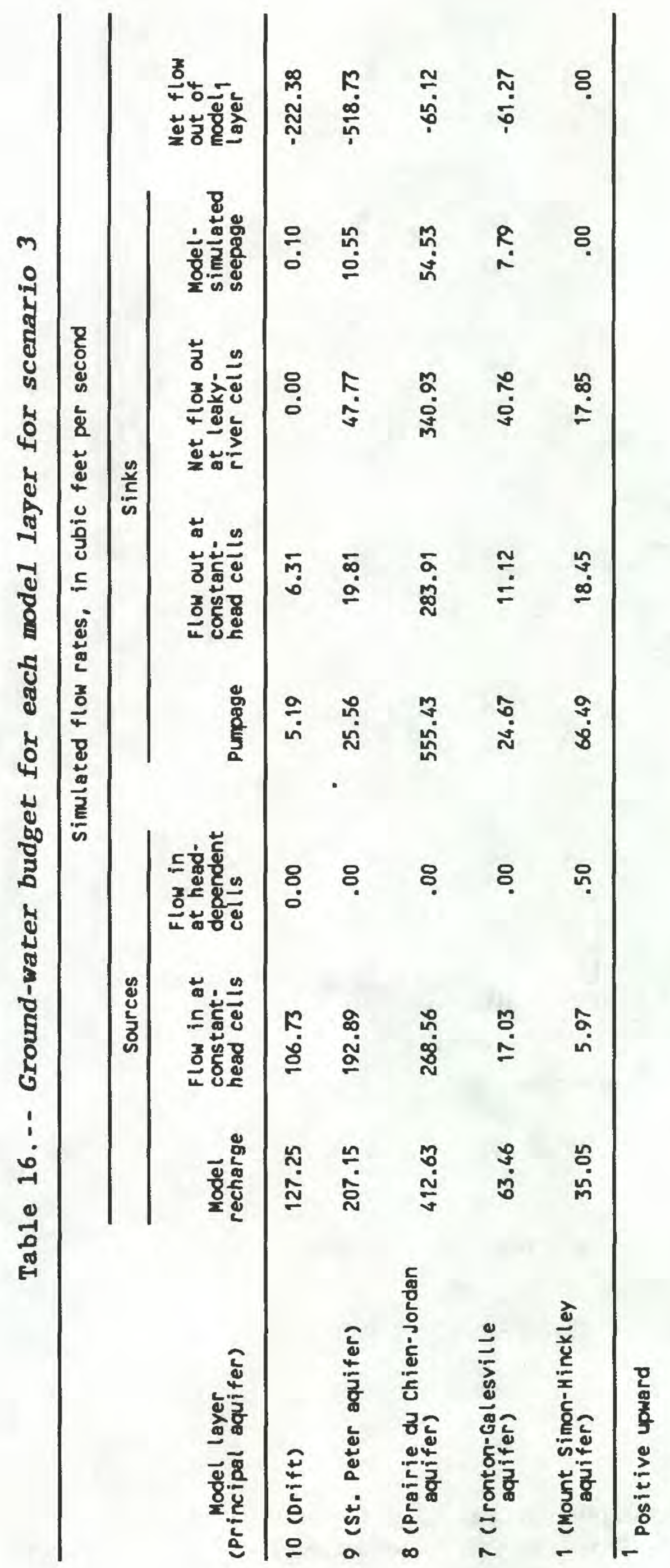




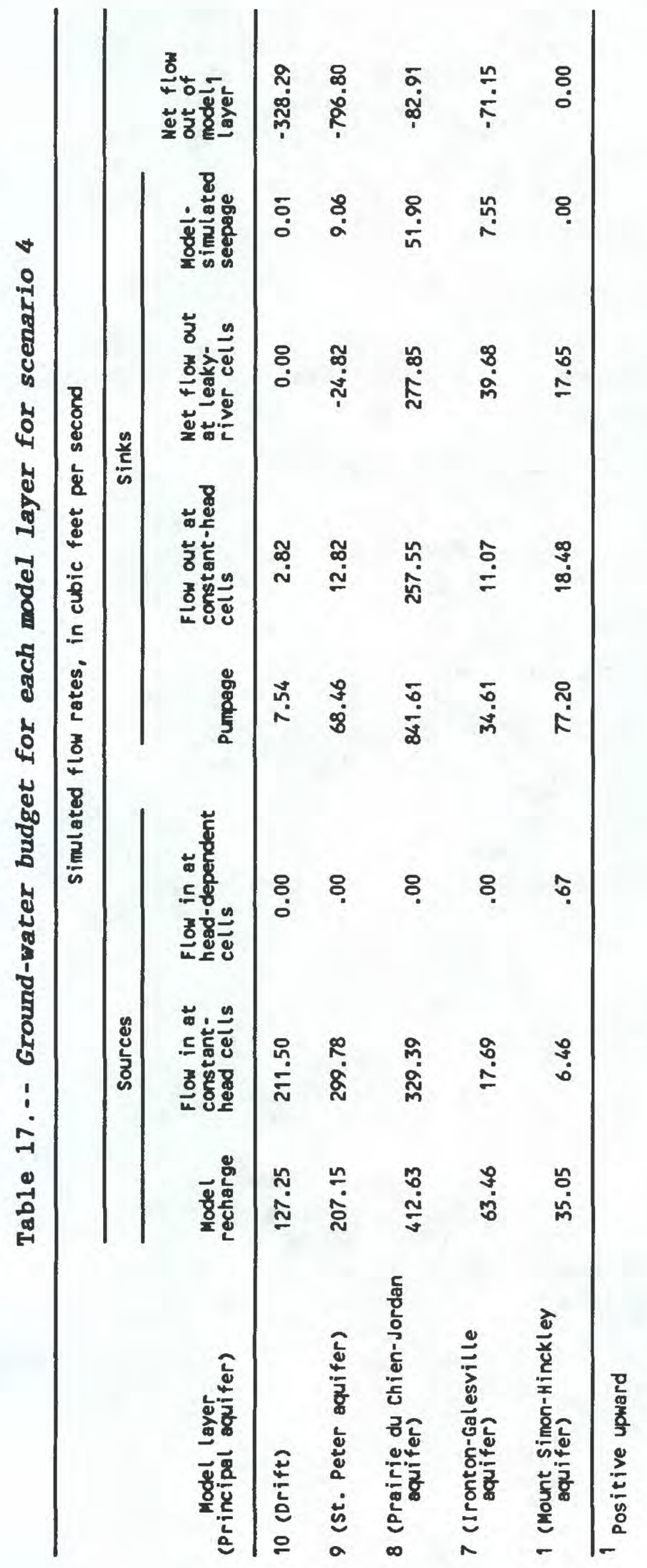


Differences between these simulated potentiometric surfaces and 1970-79 (calibration) potentiometric surfaces for layers 8 and 1 are shown in figures $42 a$, and $42 b$, respectively. Table 9 lists both the maximum change from the calibration simulation as well as a detailed listing of all apparent cones of depression simulated by the model. In this simulation, the maximum head differences from the heads calculated in the 1970-79 (calibration) steadystate run occur in layer 8 at the site of the St. Paul Water Utility at Vadnais Lake. Most simulated cones of depression (fig. 38, table 12) are minor. The five largest ones correspond to areas around the St. Paul Water Utility, Bloomington, New Brighton, Blaine, and Coon Rapids.

The simulation illustrates the effect of greatly increased ground-water withdrawals that were first shown by scenario 1 . The differences from the 1970-79 (calibration) period show an increase in the effective recharge rate from 4.32 to $6.4 \mathrm{in} / \mathrm{yr}$. In terms of percentage, this represents a 48 -percent increase (table 13).

As in the simulations for scenarios 1 and 3 , the location and major differences in leakage to the major rivers between the 1970-79 simulation and this simulation occur along river segments $3,8,9$, and 10 (fig. 39, table 14). In terms of absolute and percent differences, segments 3,8 , 9, and 10 had $79,96,224$, and $270 \mathrm{ft}^{3} / \mathrm{s}$ and $30,41,40$, and 41 percent, respectively, smaller contributions to stream flow from the aquifer system. Moreover, segments 2 and 5 had decreases of 5 and $10 \mathrm{ft}^{3} / \mathrm{s}$ and 25 and 26 percent, respectively. These segments correspond to the Rum and Cannon Rivers. As successively larger simulated withdrawals were modeled (scenarios 2 and 4), reversals of flow from the river to the aquifer (instead of vice versa) were successively larger than reversals of flow simulated in scenarios 1 and 3 . Projected reversals in flow between river and aquifer extended north along the Mississippi River from about Ford Dam upstream past Minneapolis and St. Anthony Falls to about the Rum River. Reversals also were projected to occur in the vicinity of St. Paul and along the Minnesota River between Bloomington, Eden Prairie, Burnsville, Savage, in the vicinity of Nininger, and along the Cannon River near Byllesby Reservoir.

The assumption made in model construction that cells representing confined aquifers would always be fully saturated was violated in layer 8 . Simulated water levels approximate the top of the Prairie du Chien-Jordan aquifer or are within the aquifer in an area covering northern Ramsey County, the panhandle of Anoka County, a small section in northeastern Hennepin County around and connecting between the locations of simulated withdrawals by St. Paul Water Utility and the Minneapolis Water Works; the Maple Grove-OsseoBrooklyn Park area; an area in southern Hennepin County stretching from Eden Prairie to Bloomington; Cottage Grove near Nininger; and downtown Minneapolis. Heads were simulated as being below the bottom of the aquifer at the St. Paul Water Utility at Vadnais Lake, the Minneapolis Water Works treatment plant, and Eagan. Violations of the assumptions made in model construction for the scenario 4 simulation press the assumptions to the point where it is reasonable to consider the results only in a qualitative sense. 
However, given the specific distribution of ground-water withdrawals simulated, a sustained yield or maximum rate of ground-water withdrawal can be estimated. Because of the nature of modeling, this finding is best given as a range or "envelope" based upon the assumptions of the model and the sensitivity to parameter uncertainty.

One major assumption involved the placement of new wells in the model for projected ground-water withdrawals. They were placed at sites of existing wells or water-treatment plants. Thus, simulated withdrawals were more highly concentrated in space then is physically likely, and perhaps possible, in the real world. This assumption, when combined with simulated pumping rates in this scenario, exacerbated the amount of calculated hydraulic-head declines at certain cells. These declines could greatly exceed actual future declines. In addition, calculated hydraulic heads are approximately at the top of the aquifer in cells adjacent to the simulated "dry" cells. These observations suggest that the simulation of "dry" cells is an artifact of the way pumping was positioned in the model for the given well configuration. Consequently, sustained yield is estimated to be slightly below $665 \mathrm{Mgal} / \mathrm{d}$, the pumping rate simulated in this scenario. Rounding down to the nearest $50 \mathrm{Mgal} / \mathrm{d}$, a reasonable estimate for sustained yield is $650 \mathrm{Mgal} / \mathrm{d}$.

Results of sensitivity analyses suggested that model-calculated hydraulic heads at any cells might differ over ranges of $\pm 20 \mathrm{ft}$ and $\pm 50 \mathrm{ft}$ because of the uncertainty of hydraulic properties of the aquifer system and the recharge rate to the aquifer system, respectively. Model-calculated hydraulic heads at a cell can be used to relate model sensitivity to simulated pumping rates by assuming that the hydraulic head response is linear between simulations. The model response at cell $(15,30,8)$ was chosen because it is within an area of high pumpage and doesn't contain simulated pumpage. This avoids problems associated with overstated hydraulic-head declines discussed in the last paragraph. Scenario 3 was not considered because it is a variant of scenario 1. The effect of the sensitivity of the model to the uncertainty of the rechange rate is shown in figure 43 . The vertical distance between curve $A$ and curves $B$ and $C$ is $50 \mathrm{ft}$. Along a section of curve $A$ where the calculated hydraulic-head change between three simulation is a straight line, the vertical distance of $50 \mathrm{ft}$ is matched by a horizontal offset of $150 \mathrm{Mgal} / \mathrm{d}$ (230 $\mathrm{ft}^{3} / \mathrm{S}$ ). A similar analysis of the sensitivity of the model to the uncerfainty of hydraulic properties produces a horizontal offset of $60 \mathrm{Mgal} / \mathrm{d}$ ( $90 \mathrm{ft}^{3} / \mathrm{S}$ ). These values represent an envelope of uncertainty about the estimated sustained yield, which, using the larger range, can be expressed as $650 \pm 150$ Mgal/d.

\section{Mode1 Limitations}

The large scale of the model precludes detailed analysis of hydrologic conditions for local areas. More detailed, smaller-scale models of local areas need to be constructed if detailed simulations of local hydrologic characteristics are desired. The principles of model construction are similar to those employed in the construction of the model discussed in this report. However, sufficient data must be available for local areas if a model is to be successfully completed. 


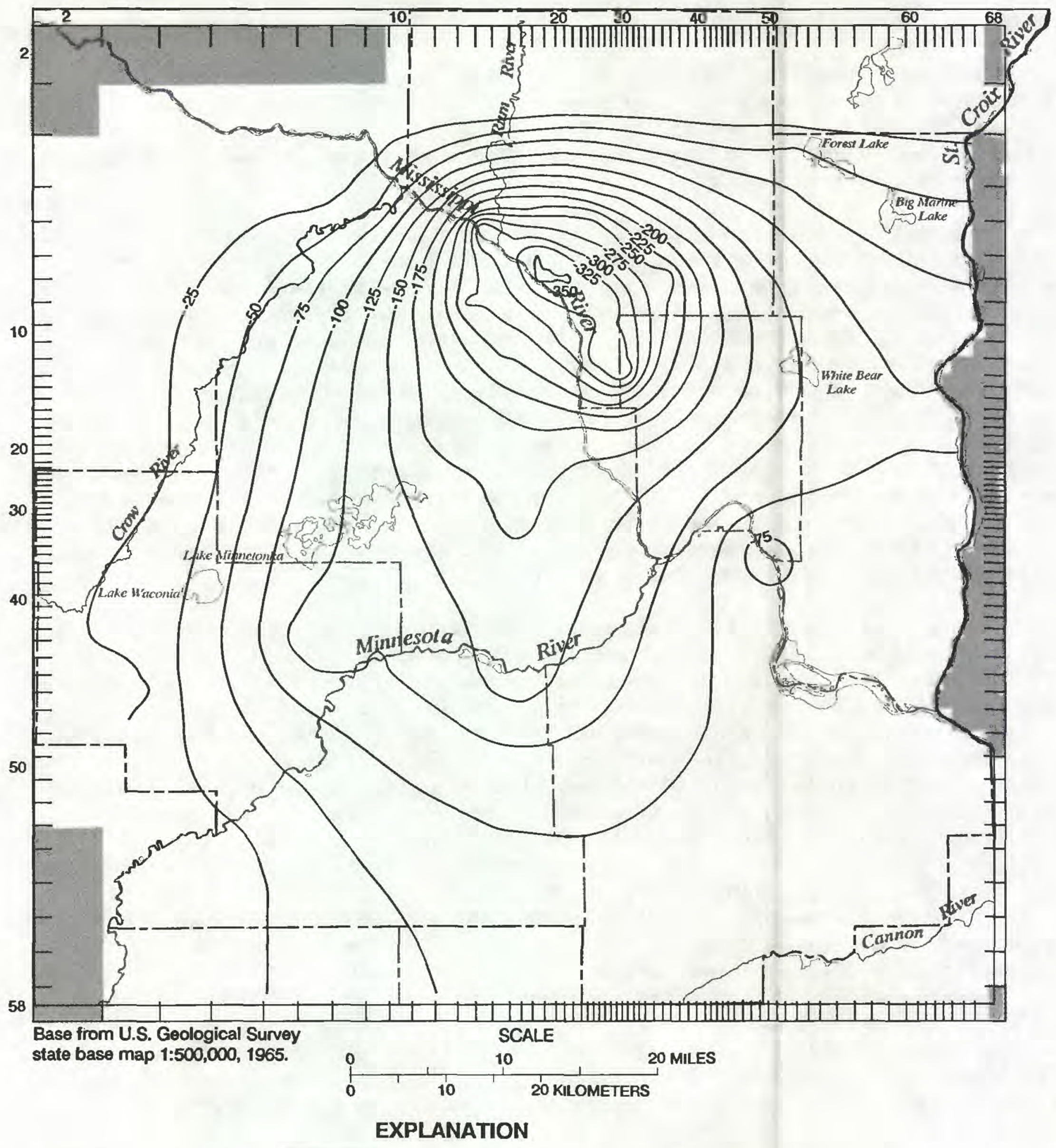

Inactive cells

-125 - Model-generated line of equal head change. Interval 25 feet.

Boundary of Twin Cities Metropolitan Area

Figure 42a.-Differences between simulated potentiometric surfaces for the calibration period and scenario 4 for model layer 1 (Mount Simon-Hinckley aquifer). 


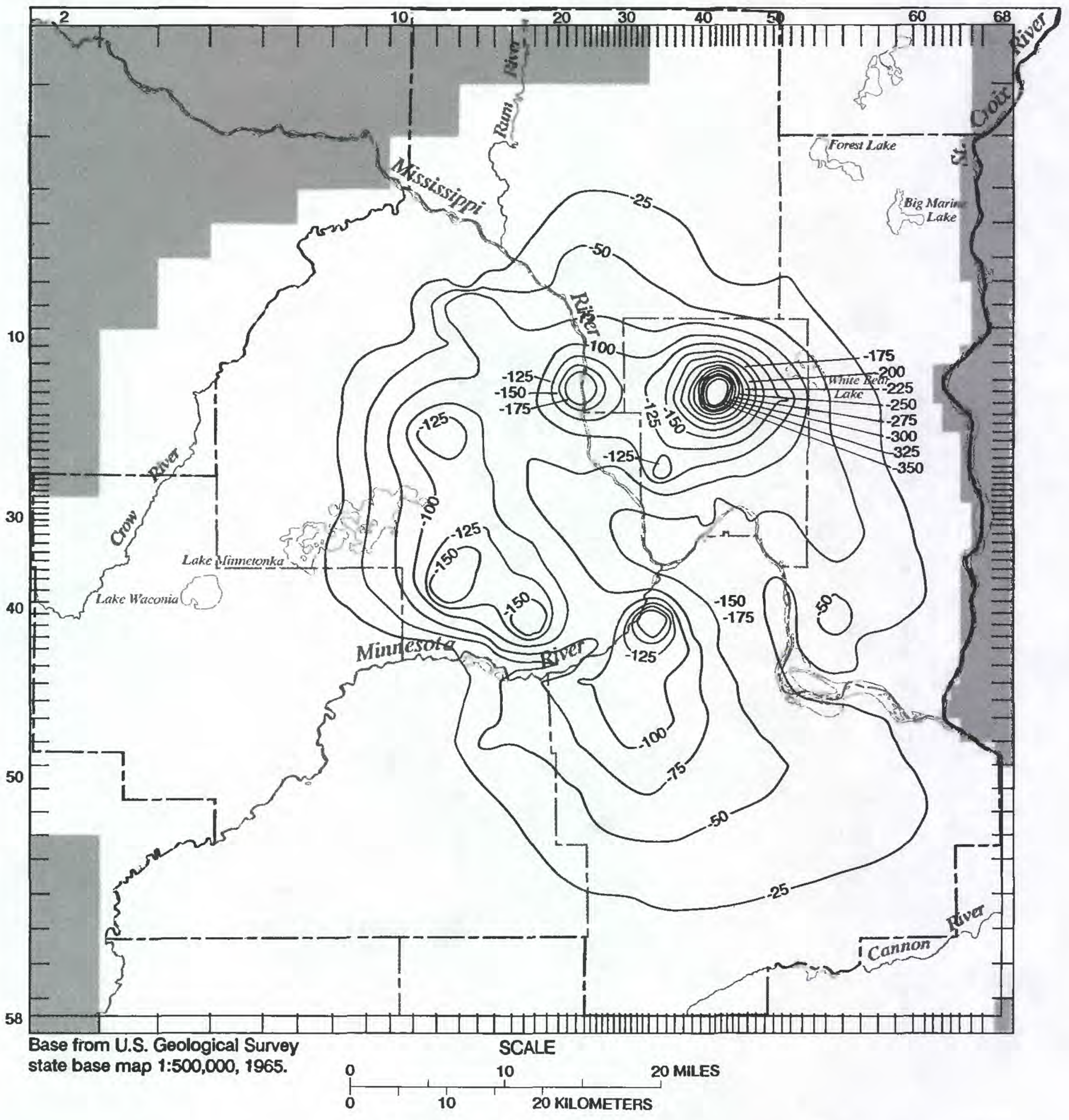

EXPLANATION

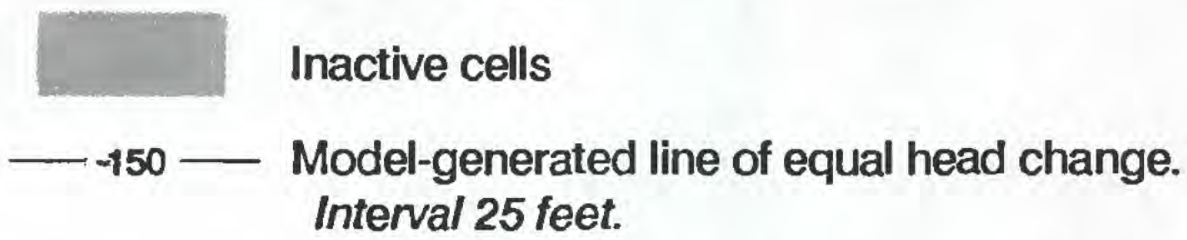

Boundary of Twin Cities Metropolitan Area

Figure 42b.-Differences between simulated potentiometric surfaces for the calibration period and scenario 4 for model layer 8 (Prairie du Chien-Jordan aquifer). 


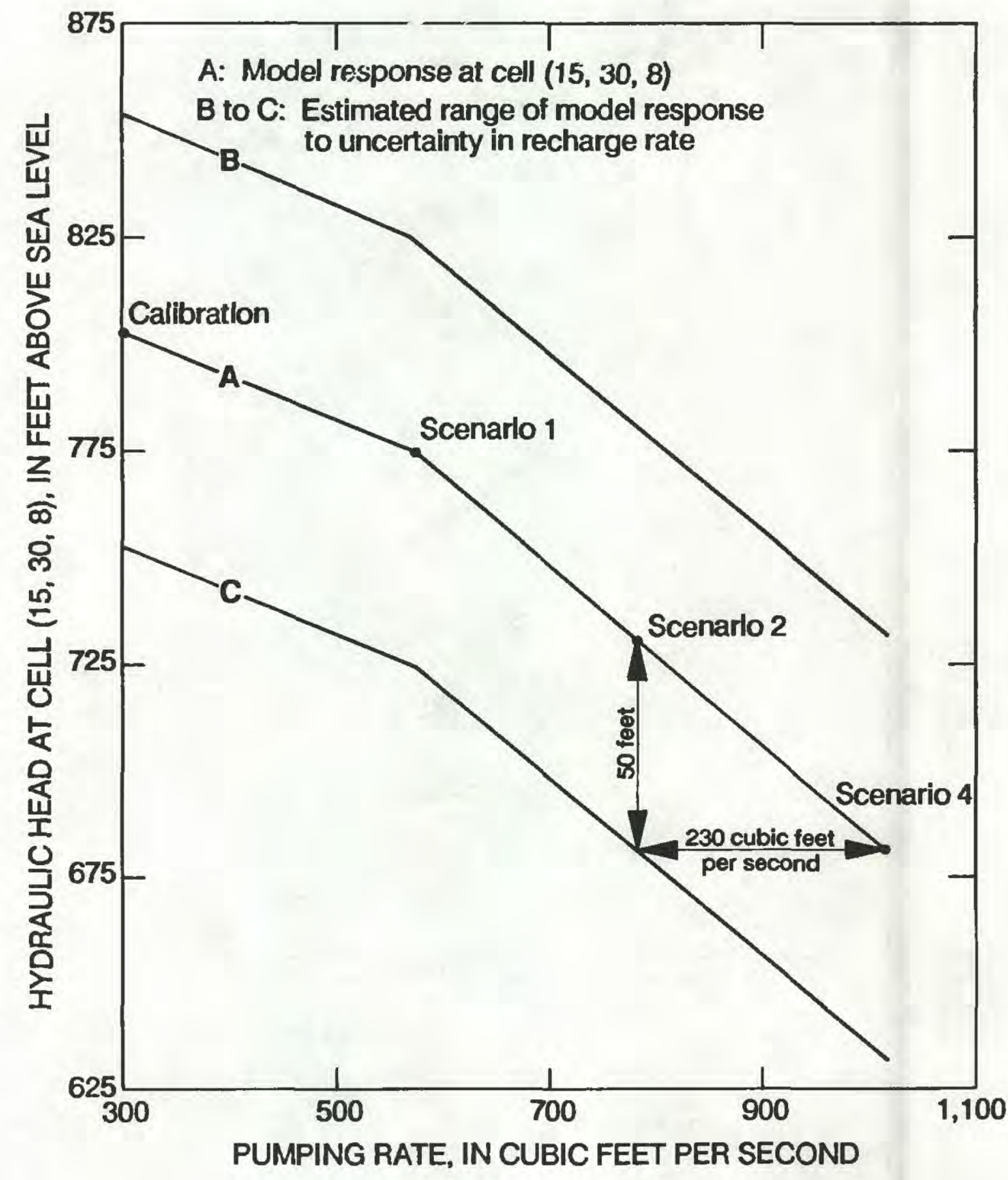

Figure 43.-Model response to increased simulated pumping rates at cell $(15,30,8)$. 
The accuracy of the model results is limited relative to flow. The steady-state condition of flow in scenario 4 projected an increase of average recharge of $1.4 \mathrm{in} / \mathrm{yr}$ to the bedrock aquifers for the modeled area. The time frame over which the projection holds is the time frame in which the aquifer system appears to reach steady state, about 4 to 6 months. Therefore, the model predictions are more reasonable projections of the probable effects of short-term drought but may underestimate the effects of long-term drought factors such as streamflow depletion.

The model results can overstate drawdown. At two locations (cells centered about $17,42,8$ and $42,16,8$ ), model-calculated heads were projected to be below the bottom of the aquifer in scenario 4. This is physically impossible and has several consequences relative to the validity and accuracy of model simulations. Consequently, the model is not quantitatively valid given the ground-water withdrawals used in scenario 4 in northern Ramsey County through the panhandle of Anoka County and in southeastern Hennepin County. Because the problem of overdrafting the aquifer hopefully would be recognized during design of the well field, the probable solution would be a combination of lower pumping rates for individual wells plus pumpage from more widely spaced well fields. The consequence of this sort of development would be an areally more extensive, but shallower, cone of depression. Different development patterns will cause different results. Detailed discussion of this problem is beyond the scope of this report. However, this report indicates the locations of potential problems.

Assumptions made in the model about the location of new wells and lack of availability of ground-water from storage, when combined with the given distribution of higher simulated pumpage rates, help define a range or an "envelope" about an "ultimate sustainable yield" or maximum ground-water withdrawal rate. The envelope reflects model sensitivity to parameter uncertainty and sheds understanding on the accuracy of the maximum ground-water withdrawal rate. Results from scenario 4 suggest that the rate is approximately 650

$\mathrm{Mgal} / \mathrm{d}$. But given a range of $\pm 150 \mathrm{Mgal} / \mathrm{d}$, the "ultimate sustainable yield" is better expressed as being between $500 \mathrm{Mgal} / \mathrm{d}$ and $800 \mathrm{Mgal} / \mathrm{d}$.

\section{NEED FOR FUTURE STUDIES}

The present numerical ground-water-flow model can serve as an indicator of where and how much additional data are needed to increase understanding of ground-water flow in the aquifer system and to provide updated information to improve the predictive capability of future models. In addition, water-leveldata networks need to be constructed with a clear understanding of the uses to which the data will be put. Otherwise, data maybe collected at such intervals as to make it practically uninterpretable and generally useless. Identified data-collection needs fall into three areas: Water levels (heads), water use, and hydraulic characteristics.

Future activities related to collection of water-level data in the study area include:

(1) regional, synoptic, water-level measurements in the various aquifers during both winter and summer at least every 10 years and preferably every 5 years; 
(2) regional, synoptic, water-level measurements for both the Mount SimonHinckley and Prairie du Chien-Jordan aquifers every winter to monitor the cumulative effect of long term, increased pumpage; and

(3) Continuous water-level data using recorders in areas of largest summer pumpage.

Future activities related to collection of ground-water-use data in the study area include:

(1) Careful study of the development of supplemental ground-water supplies for the cities of Minneapolis and St. Paul. (Results of model simulations indicate that the simultaneous development of ground-water supplies at projected withdrawal rates and locations indicated by the municipalities themselves could substantially affect the potentiomentric surface of the Prairie du Chien-Jordan aquifer);

(2) estimates of nonpermitted, hence unrecorded, water use at sites where withdrawals exceed 10 million gallons per year;

(3) estimates of future ground-water consumption based on past consumption, economic factors, population change, and climatic factors with time-series modeling methods; and

(4) coordination of the frequency of measurements of water-level data and collection of water-use data.

Specific studies of hydrologic properties of the aquifer system might include :

(1) A detailed study of the interaction between bedrock aquifers and the Mississippi, Minnesota, and St. Croix Rivers. (Because of the complex nature and extremely variable thickness of the streambed material, the calibrated values of streambed leakance are only estimates on a regional scale);

(2) improved definition of the effects of recharge from lakes and reservoirs in maintaining water levels in various aquifers;

(3) detailed determination of the vertical hydraulic conductivity of bedrock and unconsolidated confining units;

(4) improved definition of the hydrologic budget in the study area to determine the relations among surface runoff, shallow ground-water flow, intermediate ground-water flow, deep ground-water flow, and manmade and natural discharges;

(5) establishment and verification of the southern hydrologic boundary for the Mount Simon-Hinckley aquifer in the study area by means of water-level and hydraulic data;

(6) determination of the extent of buried karst terrain within the Prairie du Chien-Jordan aquifer and its hydrologic importance; and

(7) improved definition of the saturated thickness of the drift. 


\section{SUMMARY AND CONCLUSIONS}

The aquifer system contains 14 geologic formations as much as $1,000 \mathrm{ft}$ thick. The formations can be grouped into 5 aquifers and 4 confining units. Bedrock aquifers consist of sandstone with intergranular flow and limestone with high secondary permeability. The aquifers in ascending order are: the Mount Simon-Hinckley, Ironton-Galesville, Prairie du Chien-Jordan, and St. Peter aquifers. Bedrock confining units consist of silty, fine-grained sandstone and shale. The confining units in ascending order are: the Eau Claire, St. Lawrence-Franconia, Lower St. Peter, and Decorah-Platteville-Glenwood confining units. As much as $600 \mathrm{ft}$ of unconsolidated drift overlies a deeply incised bedrock surface. These unconsolidated deposits consist primarily of sandy to gravelly outwash and alluvium (aquifers) and silty to clayey till and alluvium (confining units).

The two uppermost bedrock aquifers, the St. Peter and the Prairie du Chien-Jordan, and the two uppermost bedrock confining units, the DecorahPlatteville-Glenwood and the Lower St. Peter, are extensively cut by preglacial valleys. Consequently, drift-filled valleys in the bedrock surface connect the upper two bedrock aquifers and the drift aquifer, forming a we11connected hydraulic system on a regional scale. Few bedrock valleys fully penetrate the Eau Claire confining unit and cut into the lowermost aquifer in the flow system, the Mount Simon-Hinckley. As a result, the Mount SimonHinckley aquifer is hydraulically isolated from the shallow and intermediate flow systems in the overlying interconnected aquifers.

In general, the valleys of the Mississippi, Minnesota, and St. Croix Rivers act as regional drains for the bedrock aquifers as well as the drift. The rivers form important hydraulic boundaries to all aquifers. In contrast, the valleys of the Rum, Crow, and Cannon Rivers lie in drift and generally do not cut down to bedrock except for the Cannon River, which is in the "driftless zone". The major effect of the smaller river valleys on the aquifer system is limited to controlling the shape of the water table.

In the study area, long-term precipitation generally ranges from 26 to 32 in/yr. Most of the precipitation is lost to evapotransporation, leaving only 8 to $9 \mathrm{in} / \mathrm{yr}$ for either recharge to the ground-water system or overland runoff to streams. Historically, overland runoff has been about $5 \mathrm{in} / \mathrm{yr}$. Consequently, 3 to $4 \mathrm{in} / \mathrm{yr}$ of water have been available to recharge the groundwater system.

Lakes and wetlands store overland runoff and represent locations where recharge to or discharge from the ground-water system can occur throughout the year. In addition, lake stages are relatively constant because of control structures on outlets and additions of pumped ground water to maintain lake levels.

The aquifer system was represented by a quasi-three-dimensional groundwater-flow model. Each of the 10 layers in the model has 59 east-west rows and 69 north-south columns. The top layer (layer 10) represented only drift. Al1 other layers represented both drift and bedrock. The bedrock aquifers represented are the Mount Simon-Hinckley (layer 1), Ironton-Galesville (layer 7), Prairie du Chien-Jordan (layer 8), and St. Peter (layer 9) aquifers. The Eau Claire confining unit was represented by mode1 layers 2-6. 
Model cells representing either bedrock or drift or both were assigned transmissivity values calculated from the unit's average horizontal hydraulic conductivity and thickness. In addition, either hydraulic heads or fluxes were specified for the hydraulic boundaries represented in the model and for time-varying fluxes. In the aquifer system, boundary conditions used include no-flow boundaries, head-dependent-flux boundaries, leaky streams, springs and seepage faces, and constant heads along rivers and at lakes; time-varying fluxes include recharge and pumpage.

The model simulated the most important aspects of the observed groundwater-flow system. In the Prairie du Chien-Jordan aquifer: (1) the highest water levels generally coincided with topographic highs; (2) the lowest water levels coincided with the Mississippi River where the river leaves the southeastern corner of the study area; (3) ground water generally flowed from water-level highs toward the major streams with only minor diversions of ground water at local cones of depression; and (4) ground-water-flow divides closely paralleled watershed divides. In the Mount Simon-Hinckley aquifer:

(1) the highest water levels generally coincided with the highest altitude of the aquifer in the study area; and (2) the lowest water levels coincided with either actual or projected major pumping centers.

Model results indicate that: (1) the major rivers act as regional drains for all the bedrock aquifers except the Mount Simon-Hinckley; (2) water-level highs are topographically controlled; (3) the Prairie du Chien-Jordan aquifer is highly transmissive and in good hydraulic connection both with the overlying drift and the major rivers; (4) the control on flow from the bedrock to the rivers does not depend on their direct connection, but rather on the horizontal hydraulic properties of the intervening drift; (5) there is a direct correlation between flow in the bedrock aquifers and discharge from the aquifer system to the major rivers; (6) the major effect of minor rivers is limited to controlling the shape of the water table; (7) the system was approximately in mass balance with a recharge rate of $3.5 \mathrm{in} / \mathrm{yr}$ but, because all discharge from shallow ground-water-flow subsystems is not explicitly represented in the numerical mode1, this rate only represents the flux of water through the drift to the bedrock part of the aquifer system from precipitation; and (8) lakes and wetlands help control the shape of the water table and contribute about $0.7 \mathrm{in} / \mathrm{yr}$ net recharge to the ground-water system, suggesting that the total influx of water infiltrating from land surface was about 4.2 in/yr in these areas.

The model was calibrated in steady-state against the median of observed hydraulic heads for 1971-80, with a standard deviation of the absolute residuals of about $20 \mathrm{ft}$.

The sensitivity of the model was evaluated in terms of three broad categories: Those factors that directly affect (1) horizontal flow through the ground-water system; (2) vertical flow through the ground-water system; and (3) flow influenced by boundary conditions and time-varying fluxes. The most sensitive parameters were recharge and vertical hydraulic conductivity of the drift and the Eau Claire confining unit.

Projected ground-water withdrawals of $370 \mathrm{Mgal} / \mathrm{d}, 510 \mathrm{Mgal} / \mathrm{d}$, and 670 $\mathrm{Mgal} / \mathrm{d}$ were used for simulating four scenarios with the steady-state model. Results are summarized for the Prairie du Chien-Jordan and Mount Simon-Hinckley aquifers because projected increases in ground-water use are concentrated in those aquifers. 
All four scenarios of future water use indicated the following results. For layer 8 (Prairie du Chien-Jordan aquifer): (1) the highest calculated hydraulic heads generally coincided with topographic highs; (2) the lowest calculated hydraulic heads coincided with locations of projected pumping centers; and (3) cones of depression could exist below the lowest natural outlet for the Prairie du Chien-Jordan. For layer 1 (Mount Simon-Hinckley aquifer): the highest calculated hydraulic heads generally coincided with the highest altitude of the aquifer in the study area; and (2) calculated hydraulic heads were lowest in the vicinity of either actual or projected major pumping centers.

Scenario 1, which projected future increases in pumpage from the Prairie du Chien-Jordan aquifer and aquifers in the drift, indicated that: (1) for layer 8 (Prairie du Chien-Jordan aquifer) the cones of depression could exist below the lowest natural outlet for the aquifer at Bloomington, Burnsville, and the St. Paul Water Utility at Vadnais Heights; and (2) for layer 1 (Mount Simon-Hinckley aquifer) calculated hydraulic heads were lowest at Edina and five cities in the northern tier of suburbs (Anoka, Coon Rapids, Blaine, Fridley, and New Brighton).

Scenario 2, which projected future increases in pumpage from the Prairie du Chien-Jordan aquifer and the aquifers in the drift, indicated that: (1) for layer 8 (Prairie du Chien-Jordan aquifer), cones of depression could exist below the lowest natural outlet for the Prairie du Chien-Jordan in the study area at Bloomington, Burnsville, and the St. Paul Water Utility at Vadnais Heights as well as at Eden Prairie, the Minneapolis Water Works treatment plant at Fridley, downtown Minneapolis, the Energy Park area in St. Paul, an industrial area in northwest central St. Paul, and the McCarrons Lake area in Roseville just north of the St. Paul city limits and (2) for layer 1 (Mount Simon-Hinckley aquifer), calculated hydraulic heads were lowest in the vicinity of either actual or simulated major pumping centers at Anoka, St. Louis Park, Edina, Savage, Coon Rapids, Blaine, Fridley, and New Brighton.

Scenario 3, which projected future increases in pumpage from the Prairie du Chien-Jordan and Mount Simon-Hinckley aquifers, indicated that: (1) for layer 8 (Prairie du Chien-Jordan aquifer), cones of depression could exist below the lowest natural outlet for the Prairie du Chien-Jordan in the study area at Bloomington, Burnsville, and the St. Paul Water Utility at Vadnais Heights; and (2) for layer 1 (Mount Simon-Hinckley aquifer), calculated hydraulic heads were lowest in the vicinity of either actual or projected major pumping centers at Andover, Maple Grove, and Brooklyn Park in addition to St. Louis Park, Edina, Savage, Blaine, Fridley, and New Brighton.

Scenario 4, which projected future increases in pumpage under drought conditions from the Prairie du Chien-Jordan aquifer and the drift, indicated that: (1) for layer 8 (Prairie du Chien-Jordan aquifer), cones of depression could exist below the lowest natural outlet for the Prairie du Chien-Jordan in the study area at Bloomington, Burnsville, and the St. Paul Water Utility at Vadnais Heights, Eden Prairie, the Minneapolis Water Works treatment plant at Fridley, downtown Minneapolis, the Energy Park area in St. Paul, an industrial area in northwest central St. Paul, and the McCarrons Lake area in Roseville just north of the St. Paul city limits, with additional cones of depression occurring at Minnetonka, Richfield, downtown St. Paul, the Fort Road- Jefferson Avenue in St. Paul, and Cottage Grove; and (2) for layer 1 (Mount SimonHinckley aquifer), calculated hydraulic heads were lowest in the vicinity of 
either actual or simulated major pumping centers at Anoka, St. Louis Park, Edina, Savage, Coon Rapids, Blaine, Fridley, and New Brighton.

The results of these model simulations suggests that while ground water generally will continue to flow from the water-level highs toward the major streams, the Mississippi, Minnesota, and St. Croix Rivers, increasing amounts of ground-water will be diverted to local pumping centers as pumpage increases. For ground water in the Prairie du Chien-Jordan aquifer, this general flow pattern indicates that, in the Twin Cities area, the major streams will still be the principal natural drains for the ground-water system. In addition, because the Prairie du Chien-Jordan aquifer is in good hydraulic connection with the overlying drift, increased capture of that part of precipitation which percolates to the water table as recharge by the bedrock aquifer can result in reduced water available for overland runoff and shallow groundwater flow. For the Mount Simon-Hinckley aquifer, the cone of depression centered on major pumping centers in St. Louis Park and Edina through the early 1980's may become centered on pumping centers in New Brighton and Fridley if increased future pumpage comes from the Prairie du Chien-Jordan aquifer and the drift or on pumping centers in Andover, Maple Grove, and Brooklyn Park if increased future pumpage comes from the Prairie du Chien-Jordan and Mount Simon-Hinckley aquifers.

Evaluation of the effects of increasing withdrawals suggests that future changes in water use can result in increased capture of that part of precipitation which percolates to the water table, with a consequent decreased discharge of ground water to streams and increased induced infiltration of surface water in rivers, lakes, and wetlands. If increased withdrawals are restricted to areas of population increase or to treatment-plant sites, significant declines in hydraulic heads in both the Prairie du Chien-Jordan and Mount Simon-Hinckley aquifers can be expected, perhaps reaching the point of legally defined "ground-water mining." The effects on flow to streams from the ground-water system and local reversals of flow from streams into the aquifer system may be sufficient during periods of low precipitation to reduce the ground-water contribution to surface flow out of the study area by more than 40 percent. Another consequence of changes in the ground-water-flow system due to increased withdrawals might possibly be decreased time for contaminants to travel from shallow to intermediate to deep ground-water-flow paths.

Future water availability depends on the pattern of development and the aquifer from which the water is withdrawn. On the basis of the development patterns defined for this study, approximate limits of ground-water availability in the Twin Cities Metropolitan Area are from about 500 to about 800 $\mathrm{Mgal} / \mathrm{d}$.

Results of this numerical ground-water-flow model can serve as an indicator of where and how much data need to be collected to increase understanding of ground-water flow in the aquifer system and to provide updated information to improve the predictive capability of future models. Suggested data needs include periodic monitoring of hydraulic heads and ground-water use as well as further collection and compilation of hydrogeologic data on the aquifer system. 
Austin, G. S, 1972, Paleozoic 1ithostratigraphy of southeastern Minnesota; in Sims, P. K., and Morey, G. B., eds., Geology of Minnesota: University of Minnesota Press, p. 459-473.

Baker, D. G., Nelson, W. W., and Kuehnast, E. L., 1979, Climate of Minnesota Part XII--The hydrologic cycle and soil water; Minnesota Agricultural Experiment Station Technical Bulletin 322, 23 p.

Blair, S. C., and Deutsch, W. J., 1983, Physiochemical processes occurring at the St. Paul field test facility: An interim report: Proceedings of the DOE physical and chemical energy storage annual contractors' review meeting, U.S. Department of Energy, p. 249-252.

Brown, R. G., 1985, Hydrologic factors affecting lake-level fluctuations in Big Marine Lake, Washington County, Minnesota: U.S. Geological Survey Water-Resources Investigations Report 85-4176, 23 p.

Cosby, B. J., Hornberger, G. M., Galloway, J. N., and Wright, R. F., 1985, Modeling the effects of acid deposition: Assessment of a lumped parameter model of soil water and streamwater chemistry: Water Resources Research, v. 21 , p. 51-63.

Craddock, Campbe11, Thie1, E. C., and Gross, Barton, 1963, A gravity investigation of the Precambrian of southern Minnesota and western Wisconsin: Journal of Geophysical Research, v. 68, p. 6015-6032.

Delin, G. N., and Woodward, D. G., 1985, Hydrogeologic setting and potentiometric surfaces of regional aquifers in the Hollandale embayment, southeastern Minnesota, 1980: U.S. Geological Survey Water-Supply Paper 2219, 56 p.

Durbin, T. J., Kapple, G. W., and Freckleton, J. R., 1978, Two-dimensional and three-dimensional digital flow models of the Salinas Valley ground-water basin, California; U.S. Geological Survey Water-Resources Investigations 78$113,134 \mathrm{p}$.

Ehrlich, G. G., Georlitz, D. F., Godsy, E. M., and Hult, M. F., 1982, Degradation of phenolic contamination in ground water by anaerobic bacteria: St. Louis Park, Minnesota: Ground Water, v. 20, p. 703-710.

Gunard, K. T, Hess, J. H., Zirbel, J. L., and Cornelius, C. E., 1983, Water resources data for Minnesota, water year 1982; U.S. Geological Survey Water Resources Data--Minnesota, v. 2, 449 p.

Guswa, J. H., Siegel, D. I., and Gillies, D. C., 1982, Preliminary evaluation of the ground-water-flow system in the Twin Cities Metropolitan Area, Minnesota: U.S. Geological Survey Water Resources Investigation 82-44, 65 p.

Hall, C. W., Meinzer, O. E., and Fuller, M. L., 1911, Geology and underground waters of southern Minnesota: U.S. Geological Survey Water-Supply Paper $256,406 \mathrm{p}$.

Helgesen, J. O., 1977, Ground-water appraisal of the Pineland Sands area, central Minnesota: U.S. Geological Survey Water-Resources Investigations Open-File Report 77-102, 49 p.

Helgesen, J. O., and Lindholm, G. F., 1977, Geology and water-supply potential of the Anoka sand-plain aquifer, Minnesota: Minnesota Department of Natural Resources, Division of Waters Technical Paper no. 6, $17 \mathrm{p}$.

Hobbs, H. C. and Goebel, J. E., 1982, Geologic map of Minnesota: Quaternary geology: Minnesota Geological Survey State Map Series S-1, 1 p1., scale 1: 500,000 . 
Horn, M. A., 1983, Ground-water-use trends in the Twin Cities Metropolitan Area, 1880-1980: U.S. Geological Survey Water Resources Investigations Report 83-4033, 37 p.

1984, Annual ground-water use in the Twin Cities Metropolitan Area, Minnesota, 1970-79: U.S. Geological Survey Open-File Report 84-577, 130 p.

Hoyer, M. C., and Walton, M. S., 1983, Review of testing at the University of Minnesota Aquifer Thermal Energy Storage field test facility, St. Paul, Minnesota: Proceedings of the DOE physical and chemical energy storage annual contractors' review meeting, U.S. Department of Energy, p. 240-245.

Hult, M. F., and Schoenberg, M. E., 1983, Preliminary evaluation of groundwater contamination by coal-tar derivatives, St. Louis Park area, Minnesota: U.S. Geological Survey Water-Supply Paper 2211, 53 p.

Jirsa, M. A., 01sen, B. M., and Bloomgren, B. A., 1986, Bedrock geologic and topographic maps of the seven-county Twin Cities Metropolitan Area, Minnesota: Minnesota Geological Survey Map Series Map M-55, 2 p1., scale 1: 125,000 .

Kehew, A. E., and Lord, M. L., 1986, Origin and large-scale erosional features of glacial-lake spillways in the northern Great Plains: Geological Society of America Bulletin, v. 97, p. 162-177.

Konikow, L. F. 1978, Calibration of ground-water models: Proceedings of the specialty conference on verification of mathematical and physical models in hydraulic engineering, American Society of Civil Engineers, p. 87-93.

Kuehnast, E. L., Baker, D. G., and Enz, J. W., 1975, Climate of Minnesota Part VIII--Precipitation patterns in the Minneapolis-St. Paul Metropolitan Area and surrounding counties: Minnesota Agricultural Experiment Station Technical Bulletin 301, 37 p.

Larson-Higdem, Dana, Larson, S. P., and Norvitch, R. F., 1975, Configuration of the water table and distribution of downward leakage to the Prairie du Chien-Jordan aquifer in the Minneapolis-Saint Paul Metropolitan Area: U.S. Geological Survey Open-File Report 75-342, 33 p.

Leete, J. H., 1985, Development of an operational ground water management policy based on safe yield: Minnesota Department of Natural Resources, Division of Waters, $27 \mathrm{p}$.

Liesch, B. A., 1961, Geohydrology of the Jordan aquifer in the Minneapolis-St. Paul area, Minnesota: Minnesota Conservation Department, Division of Waters Technical Paper 2, 24 p.

Lindholm, G. F., Helgesen, J. O., Broussard, W. L., and Farre11, D. F., 1974, Water resources of the lower St. Croix River watershed, east-central

Minnesota: U.S. Geological Survey Hydrologic Investigations Atlas HA-490, 3 pls., scale 1:250,000.

Lindholm, G. F., 1980, Ground-water appraisal of sand plains in Benton, Sherburne, Stearns, and Wright Counties, central Minnesota: U.S. Geological Survey Water-Resources Investigation Open-File Report 80-1285, 103 p.

Madsen, E. L., and Norvitch, R. F., 1979, Hydraulic properties and tunneling constraints, in Norvitch, R. F., and Walton, M. S., eds., Geology and hydrogeologic aspects of tunneling in the Twin Cities Area, Minnesota: U.S. Geological Survey Miscellaneous Investigations Series Map I-1157, p1. 7.

Matsch, C. L., 1983, River Warren, the southern outlet of Glacial Lake Agassiz in Teller, J. T., and Clayton, Lee eds., Glacial Lake Agassiz: Geological Association of Canada Special Paper 26, p. 231-244. 
Miller, R. T., 1983, Thermal-energy storage in a deep sandstone aquifer in Minnesota: Field observations and preliminary modeling: Proceedings of the DOE physical and chemical energy storage annual contractors' review meeting, U.S. Department of Energy, p. 246-248.

1984, Anisotropy in the Ironton and Galesville Sandstones near a thermal-energy-storage we11, St. Paul, Minnesota: Ground Water, v. 22, p. $532-537$.

1985. Preliminary modeling of an aquifer thermal-energy storage system in Selected papers in the hydrologic sciences 1985, S. Subitzky, ed.: U.S. Geological Survey Water-Supply Paper 2270, p. 1-19.

Minnesota Conservation Department, Division of Waters, 1961, Water resources of the Minneapolis-St. Paul area, Minnesota: Minnesota Conservation Department, Division of Waters Bulletin no. 11, $52 \mathrm{p}$.

Mooney, H. M., Craddock, Campbe11, Farnham, P. R., Johnson, S. H., and Volz, G., 1970, Refraction seismic investigations of the northern midcontinent gravity high: Journal of Geophysical Research, v. 75, p. 5056-5086.

Morey, G. B., 1972, Pre-Mt. Simon regolith in Sims, P. K., and Morey, G. B., eds., Geology of Minnesota: University of Minnesota Press, p. 506-508.

Mossler, J. H., 1972, Paleozoic structure and stratigraphy of the Twin City region in Sims, P. K., and Morey, G. B., eds., Geology of Minnesota: University of Minnesota Press, p. 485-497.

Nueman, S. P., 1982, Statistical characterization of aquifer heterogeneities: An overview in T. N. Narasimhan, ed., Recent trends in hydrogeology: Geological Society of America Special Paper 189, p. 81-102.

Norvitch, R. F., Ross, T. G., and Brietkrietz, Alex, 1974 Water resources outlook for the Minneapolis-St. Paul Metropolitan Area: Metropolitan Council of the Twin Cities, 219 p.

Oberts, G. L., 1984, Water use in the Twin Cities Metropolitan Area--An update: Metropolitan Council of the Twin Cities Area, Publication No. $10-84-068,58 \mathrm{p}$.

Prior, C. H., Schneider, Robert, and Durum, W. H., 1953, Water resources of the Minneapolis-St. Paul area, Minnesota: U.S. Geological Survey Circular $274,49 \mathrm{p}$.

Reeder, H. 0., 1966, Fourteen maps of parts of the ground-water reservoir in the Minneapolis-St. Paul Metropolitan Area: U.S. Geological Survey OpenFíle Maps, 14 pls., scale 1:125,000.

Reeder, H. O., Wood, W. W., Ehrlich, G. G., and Sun, R. J., 1976, Artificial recharge through a well in fissured carbonate rock, West St. Paul, Minnesota: U.S. Geological Survey Water Supply Paper 2004, 80 p.

Schoenberg, M. E., 1984, Water levels and water-level changes in the Prairie du Chien-Jordan and Mount Simon-Hinckley aquifers, Twin Cities Metropolitan Area, Minnesota, 1971-80: U.S. Geological Survey Water-Resources Investigations Report 83-4237, 23 p.

Sims, P. K. and Zietz, Isidore, 1967, Aeromagnetic and inferred Precambrian paleogeologic map of east-central Minnesota and part of Wisconsin, U.S. Geological Survey Map GP-583, 5 p., 1 p1.

Stark, J. R., and Hult, M. F., 1985, Ground-water-flow model of the Prairie du Chien-Jordan aquifer, St. Louis Park, Minnesota: U.S. Geological Survey Water-Resources Investigations Report, 57 p.

Stone, J. E., 1965, Status of urban geology in the Minneapolis-St. Paul area: Minnesota Geological Survey, Reprint Series-2, 13 p. 
Thiel, Edward, 1956, Correlation of gravity anomalies with the Keweenawan geology of Wisconsin and Minnesota: Bulletin of the Geological Society of America, v. 67, p. 1079-1100.

Thiel, G. A., 1944, The geology and underground waters of southern Minnesota: Minnesota Geological Survey Bulletin No.31, 506 p.

Torak, L. J., 1982, Modifications and corrections to the finite-difference model for simulation of three-dimensional ground-water flow: U.S. Geological Survey Water-Resources Investigations Report 82-4025, 30 p.

Trescott, P. C., 1975, Documentation of finite-difference model for simulation of three-dimensional ground-water flow: U.S. Geological Survey Open-File Report 75-438, $30 \mathrm{p}$.

Trescott, P. C., and Larson, S. P., 1976, Supplement to Open-File Report 75-438, Documentation of finite-difference model for simulation of threedimensional ground-water flow: U.S. Geological Survey Open-File Report $76-591,21 \mathrm{p}$.

U.S. Geological Survey, 1978, Water resources data for Minnesota, Water Year 1977; U.S. Geological Survey Water-Data Report MN-77-2, 449 p.

Winche11, N. H., 1888, The geology of Minnesota, 1882-1885, Vo1. II of the final report: The Geological and Natural History Survey of Minnesota, $695 \mathrm{p}$.

Winter, T. C., and Pfannkuch, H. O., 1976, Hydrogeology of a drift-filled bedrock valley near Lino Lakes, Anoka County, Minnesota: U.S. Geological Survey Journal of Research, v. 4, p. 267-276.

Woodward, D. G., 1985, Trends in municipal-well installations and aquifer utilization in southeastern Minnesota: U.S. Geological Survey Water Resources Investigations Report 83-4222, 99 p.

Woodward, D. G., 1986, Hydrogeologic framework and properties of regional aquifers in the Hollandale Embayment, southeastern Minnesota: U.S. Geological Survey Hydrologic Investigations Atlas 677, 2 pls. 
Alluvium.--A general term for clay, silt, sand, gravel, or other similar material deposited in a streambed or a flood plain during comparatively recent geologic time.

Aquifer.--A formation, group of formations, or part of a formation that contains sufficient saturated permeable material to yield significant quantities of water to wells or springs.

Aquifer system.--A heterogeneous body of bedrock or unconsolidated deposits or both that contains interbedded permeable (aquifer) and less permeable (confining unit) material acting together as a water-yielding hydraulic unit of regional extent.

Bedrock.--A general term for the rock, usually solid, that underlies soil or other unconsolidated surficial materials.

Ce11. - A block within a digital ground-water model at which hydraulic properties, boundary conditions, and hydraulic head can be fixed, or referenced, in space.

Colluvium.--Any incoherent mass of soil material or rock fragments or both deposited by rainwash, sheetwash, or slow continuous downslope creep, usually collecting at the base of gentle slopes or hillsides.

Cone of depression.--A depression in the potentiometric surface of an aquifer that has the shape of an inverted cone and develops around a well from which water is being withdrawn. It defines the "area of influence" of a well. The shape of the depression is due to the fact that the water must flow through progressively smaller cross sections as it nears the well, and hence the hydraulic gradient must be steeper.

Confined aquifer.--An aquifer bounded above and below by impermeable beds, such as clay or unfractured shale, or by beds of distinctly lower permeability than that of the aquifer itself; an aquifer containing confined ground water.

Confining unit.--A layer of "relatively impermeable" material stratigraphically adjacent to one or more aquifers. The hydraulic conductivity of the confining bed is distinctly lower than that of the adjacent aquifers. This term supplants the terms aquiclude, aquitard, and aquifuge.

Darcy's Law. - A derived formula for the flow of fluids through porous media based on the assumption that the flow is laminar and that inertia can be neglected.

Divide (ground water).--A ridge in the water table or other potentiometric surface from which the ground water represented by that line moves away in both directions.

Divide (surface water). - The line of separation, or the ridge, summit, or narrow tract of high ground that marks the boundary between two adjacent drainage basins or dividing the surface waters that flow naturally in one direction from those that flow in another direction; the line forming the rim of, or enclosing a drainage basin; a line across which no water flows.

Drawdown.--(a) The lowering of the water level in a well as a result of withdrawal. (b) The difference between the height of the water table and that of the water in a pumped well. (c) The reduction of the pressure head as a result of the withdrawal of water from a well.

Drift-filled bedrock valley.--Valley cut into the preglacial surface by erosional processes that was later filled with glacial drift. 
Evapotranspiration.--Water withdrawn from a land area by evaporation from water surfaces and from moist soil and by plant transpiration.

Gaging station.--A location on a stream at which a record of stream discharge is obtained. Within the U.S. Geological Survey, this term is used only for those stream sites where a continuous record of discharge is obtained.

Glacial drift. - A general term applied to all rock material (clay, silt, sand, gravel, boulders) transported by a glacier and deposited directly by, or from the ice, or by running water emanating from a glacier.

Hydraulic conductivity. - The volume of fluid, at the existing kinematic viscosity, that will move in unit time under a unit hydraulic gradient through a unit area measured at right angles to the direction of flow. It describes the ability of aquifer material to transmit water. Values for horizontal and vertical flow through the same material may differ.

Hydraulic head (or head). - - The height of the free surface of a body of water above a given datum at a specified point. In this report the datum is the National Geodetic Vertical Datum of 1929 (NGVD of 1929). See also glossary entry for Water Level.

Hydrogeologic unit. - -A body of rock or unconsolidated material having considerable lateral extent and forming "a geologic framework for a reasonably distinct hydrologic system."

Hydrograph.--A graph of stream stage, discharge, water level, velocity, or other property of water with respect to time.

Hydraulic boundaries.--(a) Constant-head boundary--A boundary where a part of the boundary surface of an aquifer system coincides with a surface of essentially constant head. (The word "constant," as used here, implies a value that is uniform at all points along the surface as well as through time.) (b) Head-dependent-flux boundary--The flux across a part of the boundary surface changes in response to changes in head within the aquifer adjacent to the boundary; it is a specified function of that head and varies during problem solution as the head varies. (c) No-flow boundary-- No component of flow exists normal to this boundary at every point along its length.

Infiltration.--The vertical movement of water through the land surface.

Leakage.--The act or process involving the movement of water through a porous media. For example, (a) water moving from one aquifer to another through a semiconfining unit under hydrostatic pressure; (b) water moving between rivers and aquifers through river-bottom material.

Leakage coefficient. - The rate at which water of the prevailing kinematic viscosity is transmitted through a confining unit under a unit hydraulic gradient.

Mean annual instantaneous discharge.--The arithmetric mean of instantaneous discharges during the year, given in cubic foot per second.

Outwash.--Sorted, stratified glacial drift deposited beyond the glacial ice front by melt-water streams.

Percolation.--The laminar flow of water, under hydrostatic pressure or by force of gravity, through the interstices of a rock or soil. It does not include movement through large openings such as caves.

Potentiometric surface.--An imaginary surface representing the total head of ground water and defined by the level to which water will rise in a tightly cased well. The water table of an unconfined aquifer is a particular potentiometric surface. 
Precipitation.--All forms of water particles, liquid or solid, that fall from the atmosphere and reach the ground.

Preglacial erosional surface.--Bedrock surface developed by erosional processes before the most recent period of glaciation.

Pumpage.--The quantity or discharge of water, or other liquid, pumped, such as ground water.

Recharge.--The process involved in the absorption and addition of water to the zone of saturation; also, the amount of water added.

Runoff. - That part of precipitation that appears in surface streams. It is the same as streamflow unaffected by artificial diversions, storage, or other works of man in or on the stream channels.

Sand plain.--A small outwash plain consisting chiefly of sand deposited by meltwater streams flowing from a glacier.

Saturated zone.--A thickness of rock or soil material in which all the interstices are filled with water under pressure greater than atmospheric. The upper surface of the zone of saturation is the water table.

Seepage face.--A belt along a slope, such as the bank of a stream, along which water emerges at atmospheric pressure and flows down the slope. The uppermost level at which flowing water emerges in the seepage line represents an outcrop of a water table; above it is moist material representing an outcrop of the capillary fringe.

Spring.--A place where ground water flows from a rock or soil upon the land or into a body of surface water.

Steady-state hydraulic heads. - Hydraulic heads occurring when, at any point, the magnitude and direction of the specific discharge are constant in time.

Storage.--In ground-water hydrology, storage refers to water naturally detained in a ground-water reservoir, to artificial impoundment of water in ground-water reservoirs, and to the water so impounded.

Til1. - Unsorted, unstratified glacial drift deposited directly by glacial ice.

Transient (unsteady) flow (time-dependant behavior).--Flow that results if the magnitude or direction of the specific discharge changes with time.

Transmissivity. - The rate at which water of the prevailing kinematic viscosity is transmitted through a unit width of the aquifer under a unit hydraulic gradient.

Unconfined aquifer.--An aquifer having a water surface at which the water pressure is atmospheric.

Unconsolidated deposits.--(a) Sediment that is loosely arranged or unstratified, or whose particles are not cemented together, occuring either at the surface or at depth. (b) Soil material that is in a loosely aggregated form.

Unsaturated zone.--The thickness of material between the land surface and the water table.

Water level. - The water level in a well that is in equilibrium with the ground-water flow conditions of the aquifer at the well; that is, when no water is being, or recently has been, taken from the aquifer either by pumping or by free flow.

Water table.--The upper surface of a zone of saturation where the body of ground water is not confined by an overlying impermeable zone. 
Appendix A.--Calculation of transmissivity and vertical leakage coefficients for heterogeneous hydrogeologic materials in a model cell

Hydrogeologic materials in each model cell were digitized into either bedrock or drift. Model cells with drift were then identified as having drift, drift over bedrock, fully penetrating valleys, and partially penetrating valleys. Up to four variables were used to describe cells with drift: drift thickness, bedrock thickness, direction of drift-filled bedrock-valley (either $\mathrm{E}$ for an approximate east-west direction, or $\mathrm{N}$ for an approximate north-south direction, and the fraction of the area represented by the cell which contains the buried valley. The direction of the bedrock valley was used to pick the length of the side of the cell perpendicular to the axis of the bedrock valley. This length was divided into lengths which correspond to the fractions of the cell that represent bedrock and drift. Ground-water flow in the vicinity of buried valleys was assumed to be perpendicular to the valleys for the purpose of calculating transmissivity and vertical leakage coefficients. This emphasized the hydraulic effects of buried valleys. Note that because the numeric code for ground-water flow incorporates the area of model cells into calculating flows between cells, it was necessary to use fractional parts of cell area to calculate transmissivities and vertical leakage coefficients for model cells representing buried valleys.

Four physical models formed the basis for calculation of transmissivity and vertical leakage coefficients for model cells (fig. A-1). In each of these models let the following variables be defined.

$\mathrm{T}=$ total-cell transmissivity

$\mathrm{T}_{\mathrm{K}}=$ total-cell vertical leakage coefficient

$\mathrm{K}_{\mathrm{H}}=$ horizontal hydraulic conductivity

$\mathrm{K}_{\mathrm{V}}=$ vertical hydraulic conductivity

a = thickness of drift represented in a model cell

$\mathrm{b}=$ total thickness represented by model cell; $\mathrm{b}=\mathrm{a}$ or $\mathrm{c}$

c $=$ thickness of bedrock represented in a model cell

d = fraction of length representing drift in a model cell perpendicular to a bedrock valley

e $=$ fraction of length representing bedrock in a model cell perpendicular to a bedrock valley

$f$ - thickness of partically penetrating bedrock valley represented in a model cell

$g$ = thickness of bedrock under a partially penetrating bedrock valley represented in a model cell. 
[A11 numerical-inversion calculations were performed with a computer. Subscripts $D$ and $B$ indicate drift and bedrock, respectively.]

Model number and description

1: Cell with only drift or bedrock

$$
\mathrm{T}=\mathrm{bK}_{\mathrm{H}}
$$

$$
T_{K}=\frac{k_{v}}{b}
$$

2: Drift over bedrock

$$
T=a\left(K_{H}\right)_{D}+c\left(K_{H}\right)_{B}
$$

$$
\frac{1}{T_{K}}=\frac{a}{\left(K_{V}\right)_{D}}+\frac{c}{\left(K_{V}\right)_{B}}
$$

3: Fully penetrating valley

$$
\frac{1}{T}=\frac{d}{b\left(K_{H}\right)_{B}}+\frac{e}{b\left(K_{H}\right)_{D}}
$$$$
T_{K}=\frac{d\left(K_{V}\right)_{B}}{b}+\frac{e\left(K_{V}\right)_{D}}{b}
$$

4: Partially penetrating valley (combination of models 2 and 3)

$$
T=\frac{1}{\frac{d}{f\left(K_{H}\right)_{B}}+\frac{e}{f\left(K_{H}\right)_{D}}}+g\left(K_{H}\right)_{B} \frac{1}{T_{K}}=\frac{1}{\frac{d\left(K_{V}\right)_{B}}{f}+\frac{e\left(K_{V}\right)_{D}}{f}}+\frac{1}{\frac{\left(K_{V}\right)_{B}}{g}}
$$




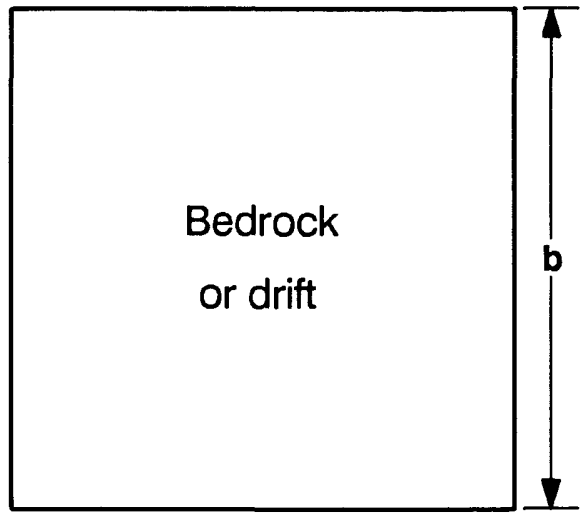

Case 1

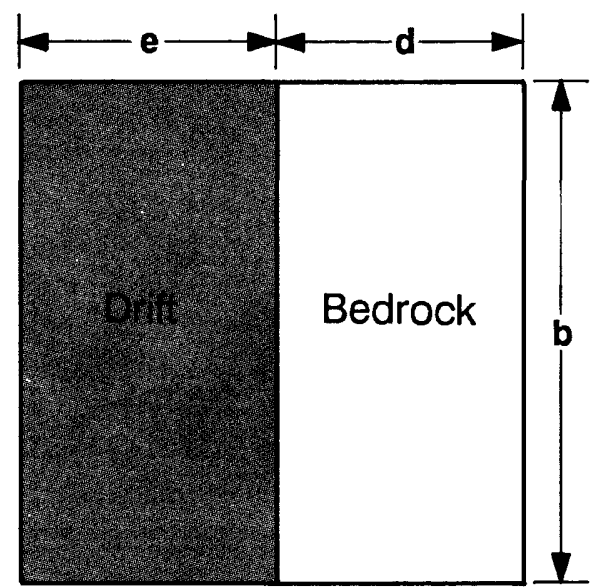

Case 3

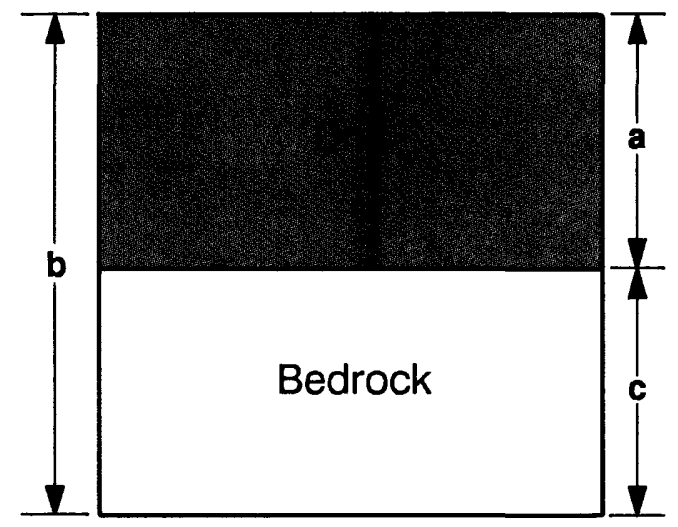

Case 2

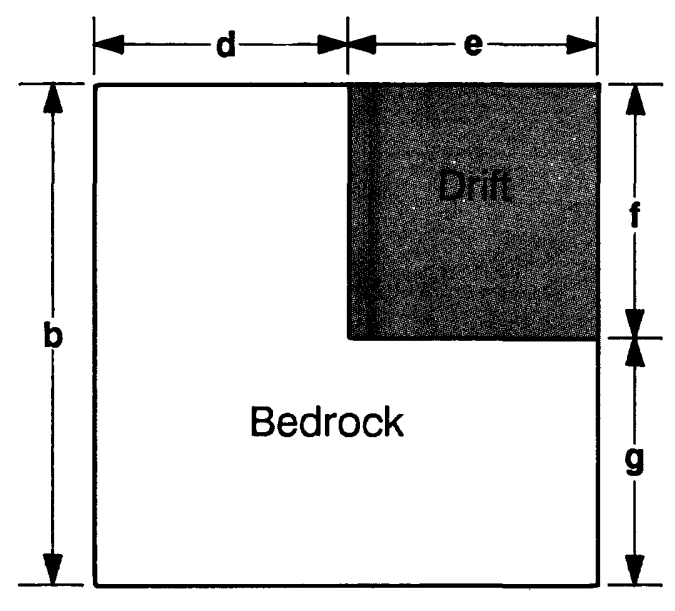

Case 4

Figure A-1.--Four physical models for the calculation of transmissivity. 


\section{Appendix B.--Withdrawals simulated at each cell for all simulations}

[in cubic feet per second; a dash indicates no value]

\begin{tabular}{|c|c|c|c|c|c|c|c|}
\hline $\begin{array}{l}\text { Model } \\
\text { layer }\end{array}$ & $\begin{array}{l}\text { Cell } \\
\text { column }\end{array}$ & $\begin{array}{l}\text { Cell } \\
\text { row }\end{array}$ & $\begin{array}{l}\text { Calibration } \\
\text { simulation } \\
(1970-79)\end{array}$ & $\begin{array}{c}\text { Scenario } \\
1\end{array}$ & $\underset{2}{\text { Scenario }}$ & $\underset{3}{\text { Scenario }}$ & $\underset{4}{\text { Scenario }}$ \\
\hline $\begin{array}{l}1 \\
1 \\
1 \\
1 \\
1 \\
1\end{array}$ & $\begin{array}{l}2 \\
3 \\
3 \\
4 \\
5 \\
5\end{array}$ & $\begin{array}{l}48 \\
46 \\
47 \\
46 \\
35 \\
37\end{array}$ & $\begin{array}{r}-0.040 \\
-.090 \\
-1.360 \\
-.060 \\
-.060 \\
-.030\end{array}$ & $\begin{array}{c}-0.005 \\
- \\
-- \\
-.088 \\
-.0106 \\
-.043\end{array}$ & $\begin{array}{c}-0.005 \\
- \\
-- \\
-.088 \\
-.106 \\
-.043\end{array}$ & $\begin{array}{c}-0.005 \\
- \\
-.088 \\
-.08 \\
-.106 \\
-.043\end{array}$ & $\begin{array}{c}-0.006 \\
- \\
-- \\
-.120 \\
-.144 \\
-.058\end{array}$ \\
\hline $\begin{array}{l}1 \\
1 \\
1 \\
1 \\
1\end{array}$ & $\begin{array}{l}6 \\
7 \\
7 \\
8 \\
9\end{array}$ & $\begin{array}{l}29 \\
44 \\
51 \\
45 \\
45\end{array}$ & $\begin{array}{r}-.460 \\
-.500 \\
-.250 \\
-.060 \\
-1.120\end{array}$ & $\begin{array}{r}-.319 \\
-2.666 \\
-- \\
-.534 \\
-.187\end{array}$ & $\begin{array}{r}-.319 \\
-2.951 \\
-- \\
-.591 \\
-.187\end{array}$ & $\begin{array}{c}-.319 \\
-2.666 \\
-. \\
-.534 \\
-.187\end{array}$ & $\begin{array}{r}-. .436 \\
-3.946 \\
-.0 \\
-.790 \\
-.236\end{array}$ \\
\hline $\begin{array}{l}1 \\
1 \\
1 \\
1 \\
1\end{array}$ & $\begin{array}{l}10 \\
10 \\
10 \\
11 \\
12\end{array}$ & $\begin{array}{r}3 \\
44 \\
45 \\
4 \\
4\end{array}$ & $\begin{array}{l}-.030 \\
-.030 \\
-.200 \\
-.010 \\
-.010\end{array}$ & $\begin{array}{c}-.066 \\
-.064 \\
-.196 \\
-- \\
--\end{array}$ & $\begin{array}{l}-.066 \\
-.091 \\
-.292 \\
-- \\
--\end{array}$ & $\begin{array}{c}-.066 \\
-.064 \\
-.196 \\
---\end{array}$ & $\begin{array}{c}-.100 \\
-.116 \\
-.368 \\
-- \\
--\end{array}$ \\
\hline $\begin{array}{l}1 \\
1 \\
1 \\
1 \\
1\end{array}$ & $\begin{array}{l}12 \\
13 \\
13 \\
13 \\
14\end{array}$ & $\begin{array}{r}19 \\
6 \\
9 \\
11 \\
6\end{array}$ & $\begin{array}{l}-. \overline{-} \\
-.040 \\
-- \\
-.070 \\
-.510\end{array}$ & $\begin{array}{r}-1.140 \\
-.205 \\
-10.412 \\
-.177 \\
-3.910\end{array}$ & $\begin{array}{r}-1.140 \\
-.205 \\
-1.756 \\
-.202 \\
-5.647\end{array}$ & $\begin{array}{r}-1.140 \\
-.205 \\
-1.756 \\
-.177 \\
-3.910\end{array}$ & $\begin{array}{r}-1.437 \\
-.281 \\
-2.402 \\
-.274 \\
-7.612\end{array}$ \\
\hline $\begin{array}{l}1 \\
1 \\
1 \\
1 \\
1\end{array}$ & $\begin{array}{l}14 \\
14 \\
15 \\
15 \\
15\end{array}$ & $\begin{array}{r}8 \\
33 \\
6 \\
12 \\
30\end{array}$ & $\begin{array}{r}.000 \\
-.870 \\
-.370 \\
--\end{array}$ & $\begin{array}{r}-.013 \\
-. \\
-.190 \\
-2.934 \\
-.579\end{array}$ & $\begin{array}{l}-.013 \\
-- \\
-.275 \\
-.602 \\
-.579\end{array}$ & $\begin{array}{l}-.013 \\
-- \\
-.190 \\
-.602 \\
-.579\end{array}$ & $\begin{array}{l}-.018 \\
-- \\
-.370 \\
-.823 \\
-.792\end{array}$ \\
\hline $\begin{array}{l}1 \\
1 \\
1 \\
1 \\
1\end{array}$ & $\begin{array}{l}16 \\
16 \\
16 \\
16 \\
16\end{array}$ & $\begin{array}{r}2 \\
10 \\
11 \\
25 \\
28\end{array}$ & $\begin{array}{r}-.070 \\
-- \\
-.540 \\
-.920 \\
-1.110\end{array}$ & $\begin{array}{r}-.006 \\
-.287 \\
-.609 \\
--. \\
-.829\end{array}$ & $\begin{array}{r}-.006 \\
-.059 \\
-.151 \\
-- \\
-.829\end{array}$ & $\begin{array}{l}-.006 \\
-.059 \\
-.125 \\
-. . \\
-.829\end{array}$ & $\begin{array}{c}-.009 \\
-.088 \\
-.204 \\
-- \\
-1.134\end{array}$ \\
\hline $\begin{array}{l}1 \\
1 \\
1 \\
1 \\
1\end{array}$ & $\begin{array}{l}16 \\
16 \\
16 \\
17 \\
17\end{array}$ & $\begin{array}{r}33 \\
36 \\
46 \\
7 \\
11\end{array}$ & $\begin{array}{l}-.760 \\
-.170 \\
-.010 \\
-.670 \\
-.430\end{array}$ & $\begin{array}{r}-1.969 \\
-.237 \\
-3.811 \\
-4.449 \\
-1.275\end{array}$ & $\begin{array}{r}-2.046 \\
-.273 \\
-2.907 \\
-1.804 \\
-.262\end{array}$ & $\begin{array}{r}-1.969 \\
-.237 \\
-.677 \\
-1.804 \\
-.262\end{array}$ & $\begin{array}{r}-2.798 \\
-.359 \\
-3.977 \\
-2.467 \\
-.358\end{array}$ \\
\hline $\begin{array}{l}1 \\
1 \\
1 \\
1 \\
1\end{array}$ & $\begin{array}{l}17 \\
17 \\
18 \\
18 \\
19\end{array}$ & $\begin{array}{r}39 \\
42 \\
7 \\
8 \\
8\end{array}$ & $\begin{array}{r}-1.090 \\
-.190 \\
-.370 \\
-.080 \\
-.630\end{array}$ & $\begin{array}{r}-1.134 \\
-1.415 \\
-.650 \\
-.676\end{array}$ & $\begin{array}{l}-1.304 \\
--1.388 \\
-1.067 \\
-1.110\end{array}$ & $\begin{array}{c}-1.134 \\
-- \\
-.965 \\
-.650 \\
-.676\end{array}$ & $\begin{array}{l}-1.716 \\
-- \\
-1.872 \\
-1.433 \\
-1.492\end{array}$ \\
\hline $\begin{array}{l}1 \\
1 \\
1 \\
1 \\
1\end{array}$ & $\begin{array}{l}19 \\
20 \\
21 \\
21 \\
21\end{array}$ & $\begin{array}{r}11 \\
11 \\
6 \\
7 \\
8\end{array}$ & $\begin{array}{c}-.400 \\
-- \\
-- \\
-.040 \\
--\end{array}$ & $\begin{array}{c}-- \\
-.436 \\
-.681 \\
-- \\
-.424\end{array}$ & $\begin{array}{r}-. \overline{336} \\
-1.229 \\
-.881\end{array}$ & $\begin{array}{l}-. \overline{-} \\
-.436 \\
-.681 \\
-.424\end{array}$ & $\begin{array}{r}-.5 \\
-.596 \\
-1.647 \\
-1.177\end{array}$ \\
\hline $\begin{array}{l}1 \\
1 \\
1 \\
1 \\
1\end{array}$ & $\begin{array}{l}21 \\
21 \\
22 \\
22 \\
22\end{array}$ & $\begin{array}{r}20 \\
22 \\
7 \\
8 \\
24\end{array}$ & $\begin{array}{l}-.120 \\
-.270 \\
-.940 \\
-.200 \\
.000\end{array}$ & $\begin{array}{c}-- \\
-\overline{-} \\
-2.919 \\
-.801 \\
--\end{array}$ & $\begin{array}{c}-- \\
-\overline{-} \\
-1.183 \\
-.325 \\
--\end{array}$ & $\begin{array}{c}-- \\
-- \\
-1.183 \\
-.325 \\
--\end{array}$ & $\begin{array}{c}-- \\
-- \\
-1.618 \\
-.444 \\
--\end{array}$ \\
\hline $\begin{array}{l}1 \\
1 \\
1 \\
1 \\
1\end{array}$ & $\begin{array}{l}23 \\
23 \\
23 \\
23 \\
23\end{array}$ & $\begin{array}{l}16 \\
20 \\
22 \\
23 \\
24\end{array}$ & $\begin{array}{r}-.010 \\
-1.490 \\
-.050 \\
-.010 \\
-.320\end{array}$ & $\begin{array}{c}-- \\
\overline{-} \\
-.118 \\
-\overline{123}\end{array}$ & $\begin{array}{c}-- \\
\overline{-} \\
-.118 \\
-. \overline{123}\end{array}$ & $\begin{array}{c}-- \\
\overline{-} \\
-.118 \\
-\overline{123}\end{array}$ & $\begin{array}{c}-- \\
-- \\
-.125 \\
-\overline{-132}\end{array}$ \\
\hline $\begin{array}{l}1 \\
1 \\
1 \\
1 \\
1\end{array}$ & $\begin{array}{l}23 \\
23 \\
24 \\
24 \\
24\end{array}$ & $\begin{array}{r}37 \\
45 \\
6 \\
7 \\
8\end{array}$ & $\begin{array}{l}-.160 \\
-.020 \\
-- \\
-.300 \\
-.060\end{array}$ & $\begin{array}{r}-. .416 \\
-.702 \\
-1.216 \\
-.274 \\
-.325\end{array}$ & $\begin{array}{r}-. .423 \\
-1.172 \\
-1.473 \\
-.332 \\
-.393\end{array}$ & $\begin{array}{r}-.416 \\
-.702 \\
-1.216 \\
-.274 \\
-.325\end{array}$ & $\begin{array}{r}-.576 \\
-1.543 \\
-1.983 \\
-.447 \\
-.529 \star\end{array}$ \\
\hline
\end{tabular}


Appendix B.--Withdrawals simulated at each cell

for all simulations--Continued

\begin{tabular}{|c|c|c|c|c|c|c|c|}
\hline $\begin{array}{l}\text { Model } \\
\text { layer }\end{array}$ & $\begin{array}{c}\text { Cell } \\
\text { columm }\end{array}$ & $\begin{array}{l}\text { Cell } \\
\text { row }\end{array}$ & $\begin{array}{l}\text { Calibration } \\
\text { simulation } \\
\text { (1970-79) }\end{array}$ & $\begin{array}{c}\text { Scenario } \\
1\end{array}$ & $\begin{array}{c}\text { Scenario } \\
2\end{array}$ & $\underset{3}{\text { Scenario }}$ & Scenario \\
\hline $\begin{array}{l}1 \\
1 \\
1 \\
1 \\
1\end{array}$ & $\begin{array}{l}24 \\
24 \\
24 \\
25 \\
25\end{array}$ & $\begin{array}{r}10 \\
24 \\
28 \\
5 \\
12\end{array}$ & $\begin{array}{r}-1.100 \\
-.020 \\
-.040 \\
-.130 \\
-1.410\end{array}$ & $\begin{array}{c}-0.363 \\
-- \\
-- \\
-.088 \\
-2.299\end{array}$ & $\begin{array}{c}-0.363 \\
-- \\
-- \\
-.088 \\
-2.869\end{array}$ & $\begin{array}{c}-0.363 \\
-- \\
-- \\
-.088 \\
-2.299\end{array}$ & $\begin{array}{c}-0.497 \\
-- \\
-- \\
-.131 \\
-3.720\end{array}$ \\
\hline $\begin{array}{l}1 \\
1 \\
1 \\
1 \\
1\end{array}$ & $\begin{array}{l}25 \\
25 \\
26 \\
27 \\
27\end{array}$ & $\begin{array}{r}13 \\
17 \\
21 \\
9 \\
25\end{array}$ & $\begin{array}{l}-.330 \\
-.050 \\
-.030 \\
-.390 \\
-.010\end{array}$ & $\begin{array}{c}-.132 \\
-- \\
-- \\
-1.899 \\
--\end{array}$ & $\begin{array}{c}-.165 \\
-- \\
-- \\
-2.301 \\
--\end{array}$ & $\begin{array}{c}-.132 \\
-- \\
-- \\
-1.899 \\
--\end{array}$ & $\begin{array}{c}-.214 \\
-- \\
-- \\
-3.097 \\
--\end{array}$ \\
\hline $\begin{array}{l}1 \\
1 \\
1 \\
1 \\
1\end{array}$ & $\begin{array}{l}27 \\
28 \\
28 \\
28 \\
28\end{array}$ & $\begin{array}{r}27 \\
6 \\
13 \\
14 \\
30\end{array}$ & $\begin{array}{c}-.010 \\
-.010 \\
-- \\
-\overline{.000}\end{array}$ & $\begin{array}{l}-\overline{-} \\
-.016 \\
-.043 \\
-.157 \\
--\end{array}$ & $\begin{array}{l}-- \\
-.016 \\
-.243 \\
-.157 \\
--\end{array}$ & $\begin{array}{l}-- \\
-.016 \\
-.043 \\
-.157 \\
--\end{array}$ & $\begin{array}{c}-- \\
-.023 \\
-.313 \\
-.215 \\
--\end{array}$ \\
\hline $\begin{array}{l}1 \\
1 \\
1 \\
1 \\
1\end{array}$ & $\begin{array}{l}29 \\
29 \\
29 \\
30 \\
31\end{array}$ & $\begin{array}{r}11 \\
13 \\
14 \\
6 \\
4\end{array}$ & $\begin{array}{c}-- \\
-- \\
-\overline{-} \\
-.010 \\
-.010\end{array}$ & $\begin{array}{r}-.195 \\
-2.436 \\
-.238 \\
-.001 \\
-.002\end{array}$ & $\begin{array}{r}-1.098 \\
-2.567 \\
-.238 \\
-.001 \\
-.002\end{array}$ & $\begin{array}{r}-.195 \\
-2.436 \\
-.238 \\
-.001 \\
-.002\end{array}$ & $\begin{array}{r}-1.414 \\
-3.499 \\
-.325 \\
-.001 \\
-.003\end{array}$ \\
\hline $\begin{array}{l}1 \\
1 \\
1 \\
1 \\
1\end{array}$ & $\begin{array}{l}31 \\
31 \\
32 \\
32 \\
33\end{array}$ & $\begin{array}{l}10 \\
13 \\
15 \\
26 \\
13\end{array}$ & $\begin{array}{c}-.350 \\
-- \\
-- \\
-.230 \\
--\end{array}$ & $\begin{array}{l}-.350 \\
-.242 \\
-.135 \\
-- \\
-.073\end{array}$ & $\begin{array}{c}-.350 \\
-1.363 \\
-.760 \\
-- \\
-.073\end{array}$ & $\begin{array}{l}-.350 \\
-.242 \\
-.135 \\
-- \\
-.073\end{array}$ & $\begin{array}{r}-.479 \\
-1.754 \\
-.978 \\
-- \\
-.100\end{array}$ \\
\hline $\begin{array}{l}1 \\
1 \\
1 \\
1 \\
1\end{array}$ & $\begin{array}{l}36 \\
36 \\
39 \\
41 \\
41\end{array}$ & $\begin{array}{r}8 \\
28 \\
26 \\
26 \\
29\end{array}$ & $\begin{array}{l}-.100 \\
-.030 \\
-.130 \\
-.120 \\
-.150\end{array}$ & $\begin{array}{c}-1.661 \\
-- \\
-- \\
-\end{array}$ & $\begin{array}{c}-2.095 \\
-- \\
-- \\
-- \\
--\end{array}$ & $\begin{array}{c}-1.661 \\
-- \\
-- \\
-- \\
--\end{array}$ & $\begin{array}{c}-2.812 \\
-- \\
-- \\
-- \\
--\end{array}$ \\
\hline $\begin{array}{l}1 \\
1 \\
1 \\
1 \\
1\end{array}$ & $\begin{array}{l}41 \\
42 \\
43 \\
47 \\
47\end{array}$ & $\begin{array}{l}45 \\
29 \\
30 \\
35 \\
46\end{array}$ & $\begin{array}{r}-.030 \\
.000 \\
-- \\
-.030 \\
-1.780\end{array}$ & $\begin{array}{c}-- \\
-.087 \\
-- \\
--\end{array}$ & $\begin{array}{c}-- \\
-- \\
-.087 \\
-- \\
--\end{array}$ & $\begin{array}{c}-- \\
-- \\
-.087 \\
-- \\
--\end{array}$ & $\begin{array}{c}-- \\
-\overline{110} \\
-.- \\
--\end{array}$ \\
\hline $\begin{array}{l}1 \\
1 \\
1 \\
1 \\
1\end{array}$ & $\begin{array}{l}48 \\
48 \\
48 \\
49 \\
49\end{array}$ & $\begin{array}{l}36 \\
46 \\
47 \\
36 \\
37\end{array}$ & $\begin{array}{r}-.570 \\
-.070 \\
-.690 \\
-.550 \\
-4.360\end{array}$ & $\begin{array}{r}-- \\
-.490 \\
-1.115 \\
-- \\
--\end{array}$ & $\begin{array}{r}-- \\
-.490 \\
-1.115 \\
-- \\
--\end{array}$ & $\begin{array}{r}-- \\
-.490 \\
-1.115 \\
-- \\
--\end{array}$ & $\begin{array}{c}-- \\
-.618 \\
-1.406 \\
-- \\
--\end{array}$ \\
\hline $\begin{array}{l}1 \\
1 \\
1 \\
1 \\
1\end{array}$ & $\begin{array}{l}49 \\
49 \\
51 \\
51 \\
52\end{array}$ & $\begin{array}{r}38 \\
47 \\
11 \\
15 \\
4\end{array}$ & $\begin{array}{l}-.820 \\
-- \\
-.060 \\
-.380 \\
-.510\end{array}$ & $\begin{array}{r}-.351 \\
-.165 \\
-- \\
-.381 \\
-1.088\end{array}$ & $\begin{array}{r}-.351 \\
-.165 \\
-- \\
-.539 \\
-1.448\end{array}$ & $\begin{array}{c}-.351 \\
-.165 \\
-- \\
-.381 \\
-1.088\end{array}$ & $\begin{array}{c}-.442 \\
-.208 \\
-- \\
-.734 \\
-1.860\end{array}$ \\
\hline $\begin{array}{l}1 \\
1 \\
1 \\
1 \\
1\end{array}$ & $\begin{array}{l}57 \\
59 \\
60 \\
61 \\
63\end{array}$ & $\begin{array}{l}20 \\
14 \\
49 \\
14 \\
51\end{array}$ & $\begin{array}{l}-.070 \\
-- \\
-.140 \\
-.180 \\
-.120\end{array}$ & $\begin{array}{c}-.102 \\
-.001 \\
-- \\
-- \\
-.303\end{array}$ & $\begin{array}{l}-.102 \\
-.001 \\
-- \\
-- \\
-.303\end{array}$ & $\begin{array}{c}-.102 \\
-.001 \\
- \\
-- \\
-.303\end{array}$ & $\begin{array}{l}-.140 \\
-.002 \\
-- \\
-.454\end{array}$ \\
\hline $\begin{array}{l}1 \\
1 \\
1 \\
7 \\
7\end{array}$ & $\begin{array}{r}64 \\
64 \\
64 \\
2 \\
2\end{array}$ & $\begin{array}{r}4 \\
16 \\
17 \\
37 \\
46\end{array}$ & $\begin{array}{l}-.070 \\
-.190 \\
-.610 \\
-.030 \\
-.180\end{array}$ & $\begin{array}{l}-.094 \\
-.203 \\
-.965 \\
-.037 \\
-.140\end{array}$ & $\begin{array}{l}-.094 \\
-.203 \\
-.965 \\
-.037 \\
-.140\end{array}$ & $\begin{array}{l}-.094 \\
-.203 \\
-.965 \\
-.037 \\
-.140\end{array}$ & $\begin{array}{r}-.118 \\
-.256 \\
-1.217 \\
-.052 \\
-.176\end{array}$ \\
\hline $\begin{array}{l}7 \\
7 \\
7 \\
7 \\
7\end{array}$ & $\begin{array}{l}2 \\
2 \\
3 \\
3 \\
4\end{array}$ & $\begin{array}{l}47 \\
48 \\
37 \\
46 \\
40\end{array}$ & $\begin{array}{l}-.100 \\
-.010 \\
-.050 \\
-.020 \\
-.250\end{array}$ & $\begin{array}{l}-.186 \\
-.002 \\
-.051 \\
-- \\
-.234\end{array}$ & $\begin{array}{c}-.186 \\
-.002 \\
-.051 \\
-\overline{-240}\end{array}$ & $\begin{array}{c}-.186 \\
-.002 \\
-.051 \\
-- \\
-.234\end{array}$ & $\begin{array}{c}-.259 \\
-.003 \\
-.071 \\
-- \\
-.332\end{array}$ \\
\hline
\end{tabular}


Appendix B.--Withdrawals simulated at each cell

for all simulations--Continued

\begin{tabular}{|c|c|c|c|c|c|c|c|}
\hline $\begin{array}{l}\text { Model } \\
\text { layer }\end{array}$ & $\begin{array}{l}\text { Cell } \\
\text { colurm }\end{array}$ & $\begin{array}{l}\text { Cell } \\
\text { row }\end{array}$ & $\begin{array}{l}\text { Calibration } \\
\text { simulation } \\
(1970-79)\end{array}$ & $\begin{array}{c}\text { Scenario } \\
1\end{array}$ & $\begin{array}{c}\text { Scenario } \\
2\end{array}$ & $\begin{array}{c}\text { Scenario } \\
3\end{array}$ & $\underset{4}{\text { Scenario }}$ \\
\hline $\begin{array}{l}7 \\
7 \\
7 \\
7 \\
7\end{array}$ & $\begin{array}{l}4 \\
5 \\
5 \\
5 \\
6\end{array}$ & $\begin{array}{l}46 \\
35 \\
37 \\
53 \\
19\end{array}$ & $\begin{array}{r}-0.010 \\
-.010 \\
-.010 \\
-.030 \\
-.160\end{array}$ & $\begin{array}{r}-0.017 \\
-.009 \\
-.008 \\
-.013 \\
-.001\end{array}$ & $\begin{array}{r}-0.017 \\
-.009 \\
-.008 \\
-.013 \\
-.003\end{array}$ & $\begin{array}{r}-0.017 \\
-.009 \\
-.008 \\
-.013 \\
-.001\end{array}$ & $\begin{array}{r}-0.023 \\
-.012 \\
-.010 \\
-.020 \\
-.003\end{array}$ \\
\hline $\begin{array}{l}7 \\
7 \\
7 \\
7 \\
7\end{array}$ & $\begin{array}{l}6 \\
6 \\
6 \\
6 \\
7\end{array}$ & $\begin{array}{l}27 \\
31 \\
35 \\
48 \\
19\end{array}$ & $\begin{array}{c}-.020 \\
-- \\
-- \\
-- \\
-.100\end{array}$ & $\begin{array}{l}-.002 \\
-.637 \\
-.020 \\
-.011 \\
-.003\end{array}$ & $\begin{array}{l}-.002 \\
-.637 \\
-.020 \\
-.011 \\
-.006\end{array}$ & $\begin{array}{l}-.002 \\
-.637 \\
-.020 \\
-.011 \\
-.003\end{array}$ & $\begin{array}{l}-.003 \\
-.886 \\
-.028 \\
-.017 \\
-.007\end{array}$ \\
\hline $\begin{array}{l}7 \\
7 \\
7 \\
7 \\
7\end{array}$ & $\begin{array}{l}7 \\
7 \\
7 \\
7 \\
7\end{array}$ & $\begin{array}{l}31 \\
38 \\
44 \\
47 \\
51\end{array}$ & $\begin{array}{r}-.940 \\
.000 \\
-.090 \\
-.130 \\
-.020\end{array}$ & $\begin{array}{l}-.438 \\
-.001 \\
-.470 \\
-.194 \\
--\end{array}$ & $\begin{array}{l}-.438 \\
-.001 \\
-.521 \\
-.194 \\
--\end{array}$ & $\begin{array}{l}-.438 \\
-.001 \\
-.470 \\
-.194 \\
--\end{array}$ & $\begin{array}{l}-.609 \\
-.001 \\
-.706 \\
-.261 \\
--\end{array}$ \\
\hline $\begin{array}{l}7 \\
7 \\
7 \\
7 \\
7\end{array}$ & $\begin{array}{l}8 \\
8 \\
8 \\
8 \\
8\end{array}$ & $\begin{array}{l}44 \\
45 \\
46 \\
49 \\
53\end{array}$ & $\begin{array}{r}-.370 \\
-.010 \\
.000 \\
-.030 \\
-.170\end{array}$ & $\begin{array}{c}-1.506 \\
-.094 \\
-.002 \\
-- \\
--\end{array}$ & $\begin{array}{c}-1.506 \\
-.104 \\
-.002 \\
-- \\
--\end{array}$ & $\begin{array}{c}-1.506 \\
-.094 \\
-.002 \\
-- \\
--\end{array}$ & $\begin{array}{c}-2.062 \\
-.141 \\
-.003 \\
-- \\
--\end{array}$ \\
\hline $\begin{array}{l}7 \\
7 \\
7 \\
7 \\
7\end{array}$ & $\begin{array}{r}8 \\
9 \\
9 \\
10 \\
10\end{array}$ & $\begin{array}{r}56 \\
6 \\
45 \\
3 \\
44\end{array}$ & $\begin{array}{l}-.680 \\
-.140 \\
-.320 \\
-.020 \\
-.010\end{array}$ & $\begin{array}{l}-.698 \\
-.135 \\
-.094 \\
-.012 \\
-.032\end{array}$ & $\begin{array}{l}-.698 \\
-.135 \\
-.094 \\
-.012 \\
-.046\end{array}$ & $\begin{array}{l}-.698 \\
-.135 \\
-.094 \\
-.012 \\
-.032\end{array}$ & $\begin{array}{l}-.971 \\
-.188 \\
-.118 \\
-.018 \\
-.059\end{array}$ \\
\hline $\begin{array}{l}7 \\
7 \\
7 \\
7 \\
7\end{array}$ & $\begin{array}{l}10 \\
11 \\
12 \\
12 \\
13\end{array}$ & $\begin{array}{r}45 \\
3 \\
4 \\
19 \\
6\end{array}$ & $\begin{array}{r}-.040 \\
-.010 \\
.000 \\
-- \\
-.010\end{array}$ & $\begin{array}{l}-.098 \\
-.022 \\
-- \\
-.201 \\
-.036\end{array}$ & $\begin{array}{l}-.146 \\
-.022 \\
-- \\
-.201 \\
-.036\end{array}$ & $\begin{array}{l}-.098 \\
-.022 \\
-- \\
-.201 \\
-.036\end{array}$ & $\begin{array}{l}-.186 \\
-.033 \\
-- \\
-.254 \\
-.050\end{array}$ \\
\hline $\begin{array}{l}7 \\
7 \\
7 \\
7 \\
7\end{array}$ & $\begin{array}{l}13 \\
13 \\
14 \\
14 \\
14\end{array}$ & $\begin{array}{r}9 \\
11 \\
2 \\
6 \\
7\end{array}$ & $\begin{array}{r}-\overline{-} \\
-.010 \\
.000 \\
-1.680 \\
-.010\end{array}$ & $\begin{array}{r}-1.837 \\
-.031 \\
-- \\
-.876 \\
-.347\end{array}$ & $\begin{array}{r}-.310 \\
-.036 \\
-- \\
-1.265 \\
-.347\end{array}$ & $\begin{array}{l}-.310 \\
-.031 \\
-- \\
-.876 \\
-.347\end{array}$ & $\begin{array}{r}-.431 \\
-.049 \\
-- \\
-1.734 \\
-.482\end{array}$ \\
\hline $\begin{array}{l}7 \\
7 \\
7 \\
7 \\
7\end{array}$ & $\begin{array}{l}14 \\
14 \\
15 \\
15 \\
15\end{array}$ & $\begin{array}{r}8 \\
33 \\
6 \\
8 \\
9\end{array}$ & $\begin{array}{r}.000 \\
-.030 \\
-1.210 \\
-.000 \\
-.060\end{array}$ & $\begin{array}{l}-.002 \\
-.030 \\
-.763 \\
-.001 \\
--\end{array}$ & $\begin{array}{c}-.002 \\
-.036 \\
-.854 \\
-.001 \\
--\end{array}$ & $\begin{array}{l}-.002 \\
-.030 \\
-.763 \\
-.001 \\
--\end{array}$ & $\begin{array}{r}-.003 \\
-.047 \\
-1.108 \\
-.002 \\
--\end{array}$ \\
\hline $\begin{array}{l}7 \\
7 \\
7 \\
7 \\
7\end{array}$ & $\begin{array}{l}16 \\
16 \\
16 \\
16 \\
16\end{array}$ & $\begin{array}{r}4 \\
6 \\
10 \\
11 \\
46\end{array}$ & $\begin{array}{c}-.030 \\
-- \\
- \\
-.090 \\
--\end{array}$ & $\begin{array}{l}-.022 \\
-.074 \\
-.051 \\
-.107 \\
-.025\end{array}$ & $\begin{array}{l}-.022 \\
-.157 \\
-.010 \\
-.032 \\
-.025\end{array}$ & $\begin{array}{l}-.022 \\
-.074 \\
-.010 \\
-.022 \\
-.025\end{array}$ & $\begin{array}{l}-.033 \\
-.212 \\
-.016 \\
-.041 \\
-.032\end{array}$ \\
\hline $\begin{array}{l}7 \\
7 \\
7 \\
7 \\
7\end{array}$ & $\begin{array}{l}17 \\
17 \\
17 \\
18 \\
18\end{array}$ & $\begin{array}{r}7 \\
11 \\
42 \\
7 \\
8\end{array}$ & $\begin{array}{l}-.120 \\
-.080 \\
-.030 \\
-.070 \\
-.020\end{array}$ & $\begin{array}{l}-.785 \\
-.225 \\
-.256 \\
-.250 \\
-.115\end{array}$ & $\begin{array}{l}-.318 \\
-.046 \\
-.312 \\
-.245 \\
-.188\end{array}$ & $\begin{array}{l}-.318 \\
-.046 \\
-.256 \\
-.170 \\
-.115\end{array}$ & $\begin{array}{l}-.442 \\
-.064 \\
-.411 \\
-.335 \\
-.257\end{array}$ \\
\hline $\begin{array}{l}7 \\
7 \\
7 \\
7 \\
7\end{array}$ & $\begin{array}{l}18 \\
19 \\
21 \\
21 \\
21\end{array}$ & $\begin{array}{l}9 \\
8 \\
6 \\
7 \\
8\end{array}$ & $\begin{array}{l}-.050 \\
-.110 \\
-- \\
-.030 \\
--\end{array}$ & $\begin{array}{l}-.050 \\
-.119 \\
-.120 \\
-- \\
-.075\end{array}$ & $\begin{array}{c}-.050 \\
-.196 \\
-.217 \\
-- \\
-.156\end{array}$ & $\begin{array}{l}-.050 \\
-.119 \\
-.120 \\
-- \\
-.075\end{array}$ & $\begin{array}{l}-.076 \\
-.267 \\
-.295 \\
-- \\
-.211\end{array}$ \\
\hline $\begin{array}{l}7 \\
7 \\
7 \\
7 \\
7\end{array}$ & $\begin{array}{l}21 \\
22 \\
22 \\
22 \\
22\end{array}$ & $\begin{array}{r}23 \\
7 \\
8 \\
17 \\
19\end{array}$ & $\begin{array}{l}-.010 \\
-.960 \\
-.030 \\
-- \\
-.010\end{array}$ & $\begin{array}{c}-- \\
-1.039 \\
-.141 \\
-.006 \\
--\end{array}$ & $\begin{array}{r}-- \\
-1.297 \\
-.057 \\
-.006 \\
--\end{array}$ & $\begin{array}{l}-- \\
-.732 \\
-.057 \\
-.006 \\
--\end{array}$ & $\begin{array}{r}-- \\
-1.765 \\
-.080 \\
-.007 \\
--\end{array}$ \\
\hline
\end{tabular}


Appendix B.--Withdrawals simulated at each cell

for all simulations--Continued

\begin{tabular}{|c|c|c|c|c|c|c|c|}
\hline $\begin{array}{l}\text { Model } \\
\text { layer }\end{array}$ & $\begin{array}{c}\text { Cell } \\
\text { column }\end{array}$ & $\begin{array}{l}\text { Cell } \\
\text { row }\end{array}$ & $\begin{array}{l}\text { Calibration } \\
\text { simulation } \\
(1970-79)\end{array}$ & $\begin{array}{c}\text { Scenario } \\
1\end{array}$ & $\begin{array}{c}\text { Scenario } \\
2\end{array}$ & $\underset{3}{\text { Scenario }}$ & $\underset{4}{\text { Scenario }}$ \\
\hline $\begin{array}{l}7 \\
7 \\
7 \\
7 \\
7\end{array}$ & $\begin{array}{l}22 \\
22 \\
23 \\
23 \\
23\end{array}$ & $\begin{array}{l}23 \\
24 \\
19 \\
20 \\
23\end{array}$ & $\begin{array}{r}-0.020 \\
-.000 \\
-.040 \\
-.050 \\
-.010\end{array}$ & $\begin{array}{c}-0.024 \\
-.045 \\
-\overline{018}\end{array}$ & $\begin{array}{c}-0.024 \\
-.045 \\
-.- \\
-.018\end{array}$ & $\begin{array}{c}-0.024 \\
-.045 \\
-\overline{018}\end{array}$ & $\begin{array}{c}-0.025 \\
-- \\
-.057 \\
-- \\
-.020\end{array}$ \\
\hline $\begin{array}{l}7 \\
7 \\
7 \\
7 \\
7\end{array}$ & $\begin{array}{l}23 \\
23 \\
23 \\
24 \\
24\end{array}$ & $\begin{array}{r}24 \\
37 \\
45 \\
6 \\
7\end{array}$ & $\begin{array}{r}-.020 \\
-.030 \\
.000 \\
--.050\end{array}$ & $\begin{array}{l}-- \\
-.073 \\
-.124 \\
-.215 \\
-.048\end{array}$ & $\begin{array}{l}-- \\
-.075 \\
-.207 \\
-.260 \\
-.059\end{array}$ & $\begin{array}{l}--- \\
-.073 \\
-.124 \\
-.215 \\
-.048\end{array}$ & $\begin{array}{l}-- \\
-.103 \\
-.276 \\
-.355 \\
-.080\end{array}$ \\
\hline $\begin{array}{l}7 \\
7 \\
7 \\
7 \\
7\end{array}$ & $\begin{array}{l}24 \\
24 \\
25 \\
25 \\
25\end{array}$ & $\begin{array}{r}8 \\
10 \\
5 \\
7 \\
13\end{array}$ & $\begin{array}{l}-.010 \\
-.040 \\
-.020 \\
-.420 \\
-.060\end{array}$ & $\begin{array}{r}-.057 \\
-.018 \\
-.015 \\
-2.302 \\
-.023\end{array}$ & $\begin{array}{r}-.069 \\
-.018 \\
-.015 \\
-2.789 \\
-.029\end{array}$ & $\begin{array}{r}-.057 \\
-.018 \\
-.015 \\
-2.302 \\
-.023\end{array}$ & $\begin{array}{r}-.095 \\
-.025 \\
-.023 \\
-3.810 \\
-.038\end{array}$ \\
\hline $\begin{array}{l}7 \\
7 \\
7 \\
7 \\
7\end{array}$ & $\begin{array}{l}25 \\
25 \\
26 \\
26 \\
26\end{array}$ & $\begin{array}{r}17 \\
22 \\
6 \\
7 \\
8\end{array}$ & $\begin{array}{r}-.010 \\
.000 \\
-.220 \\
-.480 \\
-.390\end{array}$ & $\begin{array}{c}-- \\
-\overline{371} \\
-1.3 \overline{-} \\
-1.538\end{array}$ & $\begin{array}{c}-- \\
-- \\
-1.661 \\
\overline{-} \\
-1.863\end{array}$ & $\begin{array}{c}-- \\
-- \\
-1.371 \\
-1.538\end{array}$ & $\begin{array}{c}-- \\
-\overline{-} \\
-2.269 \\
-- \\
-2.545\end{array}$ \\
\hline $\begin{array}{l}7 \\
7 \\
7 \\
7 \\
7\end{array}$ & $\begin{array}{l}26 \\
27 \\
27 \\
27 \\
27\end{array}$ & $\begin{array}{r}10 \\
7 \\
9 \\
25 \\
27\end{array}$ & $\begin{array}{r}.000 \\
-.020 \\
.000 \\
.000\end{array}$ & $\begin{array}{r}-.006 \\
-1.927 \\
-.185 \\
-- \\
--\end{array}$ & $\begin{array}{r}-.006 \\
-2.335 \\
-.227 \\
-- \\
--\end{array}$ & $\begin{array}{r}-.006 \\
-1.927 \\
-.185 \\
-- \\
--\end{array}$ & $\begin{array}{c}-.008 \\
-3.190 \\
-.310 \\
-- \\
--\end{array}$ \\
\hline $\begin{array}{l}7 \\
7 \\
7 \\
7 \\
7\end{array}$ & $\begin{array}{l}28 \\
28 \\
28 \\
30 \\
30\end{array}$ & $\begin{array}{r}2 \\
6 \\
30 \\
6 \\
7\end{array}$ & $\begin{array}{r}-.010 \\
.000 \\
.000 \\
.000 \\
-.010\end{array}$ & $\begin{array}{r}-.059 \\
-.003 \\
-- \\
.000 \\
-.009\end{array}$ & $\begin{array}{r}-.059 \\
-.003 \\
-- \\
.000 \\
-.009\end{array}$ & $\begin{array}{l}-.059 \\
-.003 \\
-- \\
.000 \\
-.009\end{array}$ & $\begin{array}{r}-.088 \\
-.004 \\
-.000 \\
-.014\end{array}$ \\
\hline $\begin{array}{l}7 \\
7 \\
7 \\
7 \\
7\end{array}$ & $\begin{array}{l}31 \\
31 \\
32 \\
33 \\
33\end{array}$ & $\begin{array}{l}4 \\
10 \\
26 \\
26 \\
27\end{array}$ & $\begin{array}{r}.000 \\
-.080 \\
-.050 \\
-.060 \\
-.170\end{array}$ & $\begin{array}{c}.000 \\
-.049 \\
-- \\
-- \\
--\end{array}$ & $\begin{array}{c}.000 \\
-.049 \\
-- \\
--\end{array}$ & $\begin{array}{r}.000 \\
-.049 \\
-- \\
-- \\
--\end{array}$ & $\begin{array}{c}-.001 \\
-.068 \\
-- \\
-- \\
--\end{array}$ \\
\hline $\begin{array}{l}7 \\
7 \\
7 \\
7 \\
7\end{array}$ & $\begin{array}{l}34 \\
34 \\
34 \\
35 \\
36\end{array}$ & $\begin{array}{r}9 \\
26 \\
32 \\
8 \\
8\end{array}$ & $\begin{array}{l}-- \\
-.040 \\
-.010 \\
-- \\
-.150\end{array}$ & $\begin{array}{l}-.584 \\
-- \\
-- \\
-.255 \\
-.293\end{array}$ & $\begin{array}{l}-.707 \\
-- \\
-- \\
-.255 \\
-.370\end{array}$ & $\begin{array}{l}-.584 \\
-- \\
-.255 \\
-.253 \\
-.293\end{array}$ & $\begin{array}{c}-.966 \\
-- \\
-- \\
-.355 \\
-.503\end{array}$ \\
\hline $\begin{array}{l}7 \\
7 \\
7 \\
7 \\
7\end{array}$ & $\begin{array}{l}37 \\
38 \\
40 \\
41 \\
42\end{array}$ & $\begin{array}{r}52 \\
7 \\
15 \\
45 \\
28\end{array}$ & $\begin{array}{l}-.030 \\
-.040 \\
-.010 \\
-.010 \\
.000\end{array}$ & $\begin{array}{c}-- \\
-.062 \\
-- \\
--\end{array}$ & $\begin{array}{c}-- \\
-.062 \\
-- \\
-- \\
--\end{array}$ & $\begin{array}{c}-- \\
-.062 \\
-- \\
--\end{array}$ & $\begin{array}{c}-- \\
-.067 \\
-- \\
-- \\
--\end{array}$ \\
\hline $\begin{array}{l}7 \\
7 \\
7 \\
7 \\
7\end{array}$ & $\begin{array}{l}43 \\
45 \\
47 \\
47 \\
48\end{array}$ & $\begin{array}{r}8 \\
26 \\
35 \\
46 \\
5\end{array}$ & $\begin{array}{l}-.010 \\
-.120 \\
-.010 \\
-.310 \\
--\end{array}$ & $\begin{array}{c}-\overline{112} \\
-.- \\
-\overline{430}\end{array}$ & $\begin{array}{c}-\overline{-} \\
-.112 \\
-- \\
-1.430\end{array}$ & $\begin{array}{c}-\overline{112} \\
-.12 \\
-\overline{-1.430}\end{array}$ & $\begin{array}{c}-\overline{-} \\
-.141 \\
-\overline{-} \\
-1.803\end{array}$ \\
\hline $\begin{array}{l}7 \\
7 \\
7 \\
7 \\
7\end{array}$ & $\begin{array}{l}48 \\
48 \\
49 \\
49 \\
49\end{array}$ & $\begin{array}{l}36 \\
46 \\
20 \\
36 \\
37\end{array}$ & $\begin{array}{r}-.100 \\
.000 \\
.000 \\
-.110 \\
-.770\end{array}$ & $\begin{array}{c}-- \\
-.005 \\
-- \\
--\end{array}$ & $\begin{array}{c}-- \\
-.005 \\
-- \\
-- \\
--\end{array}$ & $\begin{array}{c}-.005 \\
-- \\
--\end{array}$ & $\begin{array}{c}-- \\
-.006 \\
-- \\
--\end{array}$ \\
\hline $\begin{array}{l}7 \\
7 \\
7 \\
7 \\
7\end{array}$ & $\begin{array}{l}49 \\
51 \\
52 \\
52 \\
57\end{array}$ & $\begin{array}{r}38 \\
11 \\
4 \\
11 \\
20\end{array}$ & $\begin{array}{l}-.140 \\
-.010 \\
-.100 \\
-.030 \\
-.010\end{array}$ & $\begin{array}{c}-.062 \\
-- \\
-.003 \\
-- \\
--\end{array}$ & $\begin{array}{c}-.062 \\
-- \\
-.004 \\
-- \\
--\end{array}$ & $\begin{array}{c}-.062 \\
-- \\
-.003 \\
-- \\
--\end{array}$ & $\begin{array}{c}-.078 \\
-- \\
-.006 \\
-- \\
--\end{array}$ \\
\hline
\end{tabular}


Appendix B.--Withdrawals simulated at each cell

for all simulations--Continued

\begin{tabular}{|c|c|c|c|c|c|c|c|}
\hline $\begin{array}{l}\text { Model } \\
\text { layer }\end{array}$ & $\begin{array}{c}\text { Cell } \\
\text { column }\end{array}$ & $\begin{array}{l}\text { Cel1 } \\
\text { row }\end{array}$ & $\begin{array}{l}\text { Calibration } \\
\text { simulation } \\
(1970-79)\end{array}$ & $\begin{array}{c}\text { Scenario } \\
1\end{array}$ & $\underset{2}{\text { Scenario }}$ & $\underset{3}{\text { Scenario }}$ & $\underset{4}{\text { Scenario }}$ \\
\hline $\begin{array}{l}7 \\
7 \\
7 \\
7 \\
7\end{array}$ & $\begin{array}{l}59 \\
60 \\
61 \\
62 \\
63\end{array}$ & $\begin{array}{l}14 \\
49 \\
14 \\
28 \\
17\end{array}$ & $\begin{array}{r}-- \\
-0.020 \\
-.030 \\
-.020 \\
-.0150\end{array}$ & $\begin{array}{c}0.000 \\
-- \\
-- \\
-.165\end{array}$ & $\begin{array}{c}0.000 \\
-- \\
-- \\
-.165\end{array}$ & $\begin{array}{c}0.000 \\
-- \\
=- \\
-.165\end{array}$ & $\begin{array}{c}0.000 \\
-- \\
-- \\
-.229\end{array}$ \\
\hline $\begin{array}{l}7 \\
7 \\
7 \\
7 \\
7\end{array}$ & $\begin{array}{l}63 \\
63 \\
63 \\
64 \\
64\end{array}$ & $\begin{array}{r}18 \\
40 \\
51 \\
4 \\
17\end{array}$ & $\begin{array}{l}-.340 \\
-.170 \\
-.020 \\
-.010 \\
-.110\end{array}$ & $\begin{array}{l}-.192 \\
-- \\
-.053 \\
-.017 \\
-.170\end{array}$ & $\begin{array}{l}-.192 \\
-- \\
-.053 \\
-.017 \\
-.170\end{array}$ & $\begin{array}{l}-.192 \\
-- \\
-.053 \\
-.017 \\
-.170\end{array}$ & $\begin{array}{l}-.267 \\
-- \\
-.080 \\
-.021 \\
-.215\end{array}$ \\
\hline $\begin{array}{l}7 \\
8 \\
8 \\
8 \\
8\end{array}$ & $\begin{array}{r}64 \\
2 \\
2 \\
3 \\
3\end{array}$ & $\begin{array}{l}27 \\
47 \\
48 \\
25 \\
26\end{array}$ & $\begin{array}{l}-.030 \\
-.100 \\
-- \\
-.180 \\
-.080\end{array}$ & $\begin{array}{l}-.032 \\
-.057 \\
-.040 \\
-.289 \\
-.009\end{array}$ & $\begin{array}{l}-.032 \\
-.057 \\
-.040 \\
-.289 \\
-.009\end{array}$ & $\begin{array}{l}-.032 \\
-.057 \\
-.040 \\
-.289 \\
-.009\end{array}$ & $\begin{array}{l}-.040 \\
-.077 \\
-.054 \\
-.415 \\
-.013\end{array}$ \\
\hline $\begin{array}{l}8 \\
8 \\
8 \\
8 \\
8\end{array}$ & $\begin{array}{l}3 \\
4 \\
4 \\
4 \\
5\end{array}$ & $\begin{array}{r}53 \\
29 \\
40 \\
53 \\
7\end{array}$ & $\begin{array}{l}-.020 \\
-.040 \\
-.340 \\
-.400 \\
-.160\end{array}$ & $\begin{array}{l}-.039 \\
-.- \\
-.285 \\
-.573 \\
-.182\end{array}$ & $\begin{array}{l}-.039 \\
-.- \\
-.292 \\
-.573 \\
-.182\end{array}$ & $\begin{array}{l}-.039 \\
-.- \\
-.285 \\
-.573 \\
-.182\end{array}$ & $\begin{array}{l}-.059 \\
-. .417 \\
-.823 \\
-.262\end{array}$ \\
\hline $\begin{array}{l}8 \\
8 \\
8 \\
8 \\
8\end{array}$ & $\begin{array}{l}5 \\
5 \\
6 \\
6 \\
6\end{array}$ & $\begin{array}{l}53 \\
54 \\
27 \\
31 \\
38\end{array}$ & $\begin{array}{r}-.350 \\
-.020 \\
-.020 \\
-1.160 \\
--\end{array}$ & $\begin{array}{l}-. \\
-.224 \\
-.046 \\
-.956 \\
-.018\end{array}$ & $\begin{array}{l}-- \\
-.224 \\
-.046 \\
-.956 \\
-.018\end{array}$ & $\begin{array}{l}-- \\
-.224 \\
-.046 \\
-.956 \\
-.018\end{array}$ & $\begin{array}{r}-.- \\
-.336 \\
-.061 \\
-1.373 \\
-.027\end{array}$ \\
\hline $\begin{array}{l}8 \\
8 \\
8 \\
8 \\
8\end{array}$ & $\begin{array}{l}7 \\
7 \\
7 \\
8 \\
8\end{array}$ & $\begin{array}{l}31 \\
36 \\
38 \\
22 \\
30\end{array}$ & $\begin{array}{r}-.330 \\
-- \\
.000 \\
-.230 \\
-.140\end{array}$ & $\begin{array}{l}-.424 \\
-.008 \\
-.015 \\
-.280 \\
--\end{array}$ & $\begin{array}{l}-.424 \\
-.008 \\
-.015 \\
-.331 \\
--.\end{array}$ & $\begin{array}{l}-.424 \\
-.008 \\
-.015 \\
-.280 \\
---\end{array}$ & $\begin{array}{l}-.571 \\
-.010 \\
-.020 \\
-.431 \\
-.\end{array}$ \\
\hline $\begin{array}{l}8 \\
8 \\
8 \\
8 \\
8\end{array}$ & $\begin{array}{l}8 \\
8 \\
8 \\
8 \\
8\end{array}$ & $\begin{array}{l}34 \\
35 \\
37 \\
39 \\
45\end{array}$ & $\begin{array}{l}-.120 \\
-.550 \\
-.040 \\
-.160 \\
-.050\end{array}$ & $\begin{array}{l}-.170 \\
-.876 \\
-.121 \\
-.181 \\
-.049\end{array}$ & $\begin{array}{r}-.170 \\
-1.122 \\
-.866 \\
-1.299 \\
-.049\end{array}$ & $\begin{array}{l}-.170 \\
-.876 \\
-.121 \\
-.181 \\
-.049\end{array}$ & $\begin{array}{r}-.229 \\
-1.419 \\
-1.110 \\
-1.666 \\
-.052\end{array}$ \\
\hline $\begin{array}{l}8 \\
8 \\
8 \\
8 \\
8\end{array}$ & $\begin{array}{l}8 \\
8 \\
9 \\
9 \\
9\end{array}$ & $\begin{array}{l}46 \\
49 \\
22 \\
34 \\
39\end{array}$ & $\begin{array}{c}-.050 \\
-.240 \\
-.000 \\
.000\end{array}$ & $\begin{array}{l}-.035 \\
-.089 \\
-.110 \\
-.057 \\
-.060\end{array}$ & $\begin{array}{l}-.035 \\
-.089 \\
-.130 \\
-.057 \\
-.433\end{array}$ & $\begin{array}{l}-.035 \\
-.089 \\
-.110 \\
-.057 \\
-.060\end{array}$ & $\begin{array}{l}-.047 \\
-.112 \\
-.169 \\
-.077 \\
-.555\end{array}$ \\
\hline $\begin{array}{l}8 \\
8 \\
8 \\
8 \\
8\end{array}$ & $\begin{array}{r}9 \\
9 \\
10 \\
10 \\
10\end{array}$ & $\begin{array}{l}40 \\
45 \\
21 \\
23 \\
24\end{array}$ & $\begin{array}{r}-.- \\
-.640 \\
.000 \\
-- \\
-.250\end{array}$ & $\begin{array}{r}-.060 \\
-1.592 \\
-.679 \\
-.093 \\
-.310\end{array}$ & $\begin{array}{r}-.433 \\
-1.592 \\
-1.153 \\
-.093 \\
-.327\end{array}$ & $\begin{array}{r}-.060 \\
-1.592 \\
-.679 \\
-.093 \\
-.310\end{array}$ & $\begin{array}{r}-.555 \\
-2.006 \\
-1.497 \\
-.140 \\
-.436\end{array}$ \\
\hline $\begin{array}{l}8 \\
8 \\
8 \\
8 \\
8\end{array}$ & $\begin{array}{l}10 \\
10 \\
10 \\
10 \\
11\end{array}$ & $\begin{array}{l}34 \\
39 \\
44 \\
45 \\
19\end{array}$ & $\begin{array}{r}-.190 \\
-.090 \\
-.570 \\
-1.200\end{array}$ & $\begin{array}{r}-.446 \\
-.060 \\
-.545 \\
-1.665 \\
-5.989\end{array}$ & $\begin{array}{r}-.908 \\
-.433 \\
-.776 \\
-2.479 \\
-8.995\end{array}$ & $\begin{array}{r}-.446 \\
-.060 \\
-.545 \\
-1.665 \\
-5.989\end{array}$ & $\begin{array}{r}-1.174 \\
-.555 \\
-.977 \\
-3.100 \\
-11.761\end{array}$ \\
\hline $\begin{array}{l}8 \\
8 \\
8 \\
8 \\
8\end{array}$ & $\begin{array}{l}11 \\
11 \\
11 \\
11 \\
11\end{array}$ & $\begin{array}{l}20 \\
22 \\
32 \\
34 \\
35\end{array}$ & $\begin{array}{c}-.100 \\
.000 \\
-- \\
-.300 \\
-.120\end{array}$ & $\begin{array}{c}-- \\
-. \\
-.446 \\
-.446 \\
--\end{array}$ & $\begin{array}{c}-- \\
-. \\
-.908 \\
-.908 \\
--\end{array}$ & $\begin{array}{c}-- \\
-.- \\
-.446 \\
-.446 \\
--\end{array}$ & $\begin{array}{c}-- \\
-- \\
-1.174 \\
-1.174 \\
--\end{array}$ \\
\hline $\begin{array}{l}8 \\
8 \\
8 \\
8 \\
8\end{array}$ & $\begin{array}{l}11 \\
11 \\
11 \\
11 \\
12\end{array}$ & $\begin{array}{r}39 \\
44 \\
45 \\
46 \\
2\end{array}$ & $\begin{array}{c}-- \\
-.030 \\
-- \\
--\end{array}$ & $\begin{array}{c}-.054 \\
-.058 \\
-- \\
-1.673 \\
-.892\end{array}$ & $\begin{array}{c}-.094 \\
-.058 \\
-- \\
-2.380 \\
-1.816\end{array}$ & $\begin{array}{c}-.054 \\
-.058 \\
-- \\
-1.673 \\
-.892\end{array}$ & $\begin{array}{c}-.120 \\
-.073 \\
-- \\
-2.998 \\
-2.347\end{array}$ \\
\hline
\end{tabular}


Appendix B.--Withdrawals simulated at each cell

for all simulations--Continued

\begin{tabular}{|c|c|c|c|c|c|c|c|}
\hline $\begin{array}{l}\text { Mode1 } \\
\text { layer }\end{array}$ & $\begin{array}{c}\text { Cell } \\
\text { column }\end{array}$ & $\begin{array}{l}\text { Cell } \\
\text { row }\end{array}$ & $\begin{array}{l}\text { Calibration } \\
\text { simulation } \\
(1970-79)\end{array}$ & $\begin{array}{c}\text { Scenario } \\
1\end{array}$ & $\begin{array}{c}\text { Scenario } \\
2\end{array}$ & $\underset{3}{\text { Scenario }}$ & Scenario \\
\hline $\begin{array}{l}8 \\
8 \\
8 \\
8 \\
8\end{array}$ & $\begin{array}{l}12 \\
12 \\
12 \\
12 \\
12\end{array}$ & $\begin{array}{l}19 \\
20 \\
23 \\
25 \\
26\end{array}$ & $\begin{array}{c}-1.500 \\
-.260 \\
-- \\
-.030 \\
-.010\end{array}$ & $\begin{array}{r}-13.886 \\
-.197 \\
-.446 \\
-.446 \\
--\end{array}$ & $\begin{array}{r}-21.126 \\
-.296 \\
-.908 \\
-.908 \\
--\end{array}$ & $\begin{array}{r}-13.886 \\
-.197 \\
-.446 \\
-.446 \\
--\end{array}$ & $\begin{array}{r}-27.599 \\
-.387 \\
-1.174 \\
-1.174 \\
--\end{array}$ \\
\hline $\begin{array}{l}8 \\
8 \\
8 \\
8 \\
8\end{array}$ & $\begin{array}{l}12 \\
12 \\
12 \\
12 \\
12\end{array}$ & $\begin{array}{l}30 \\
32 \\
33 \\
34 \\
39\end{array}$ & $\begin{array}{l}-.040 \\
-.120 \\
-.060 \\
-.880 \\
-.840\end{array}$ & $\begin{array}{r}-- \\
-.446 \\
-.446 \\
-.446 \\
-14.140\end{array}$ & $\begin{array}{r}-- \\
-.908 \\
-.908 \\
-.908 \\
-24.452\end{array}$ & $\begin{array}{r}-.- \\
-.446 \\
-.446 \\
-.446 \\
-14.140\end{array}$ & $\begin{array}{c}-- \\
-1.174 \\
-1.174 \\
-1.174 \\
-31.417\end{array}$ \\
\hline $\begin{array}{l}8 \\
8 \\
8 \\
8 \\
8\end{array}$ & $\begin{array}{l}12 \\
12 \\
12 \\
13 \\
13\end{array}$ & $\begin{array}{r}40 \\
41 \\
45 \\
4 \\
8\end{array}$ & $\begin{array}{l}-.460 \\
-.- \\
-.920 \\
-.010 \\
-.080\end{array}$ & $\begin{array}{r}-2.911 \\
-.004 \\
-1.688 \\
-- \\
-.146\end{array}$ & $\begin{array}{r}-5.056 \\
-.004 \\
-2.311 \\
- \\
-.146\end{array}$ & $\begin{array}{r}-2.911 \\
-.004 \\
-1.688 \\
-.146\end{array}$ & $\begin{array}{r}-6.497 \\
-.006 \\
-2.911 \\
-.183\end{array}$ \\
\hline $\begin{array}{l}8 \\
8 \\
8 \\
8 \\
8\end{array}$ & $\begin{array}{l}13 \\
13 \\
13 \\
13 \\
13\end{array}$ & $\begin{array}{r}9 \\
10 \\
31 \\
32 \\
36\end{array}$ & $\begin{array}{r}-.670 \\
-.160 \\
-.890 \\
.000 \\
-.880\end{array}$ & $\begin{array}{c}-8.425 \\
-.106 \\
-1.508 \\
-- \\
-9.016\end{array}$ & $\begin{array}{c}-21.582 \\
-.106 \\
-1.800 \\
- \\
-9.940\end{array}$ & $\begin{array}{r}-18.609 \\
-.106 \\
-1.508 \\
-- \\
-9.016\end{array}$ & $\begin{array}{c}-30.694 \\
-.133 \\
-2.318 \\
-13.298\end{array}$ \\
\hline $\begin{array}{l}8 \\
8 \\
8 \\
8 \\
8\end{array}$ & $\begin{array}{l}13 \\
13 \\
14 \\
14 \\
14\end{array}$ & $\begin{array}{r}39 \\
45 \\
3 \\
6 \\
17\end{array}$ & $\begin{array}{r}-.080 \\
-9.240 \\
-.010 \\
-.230 \\
-.020\end{array}$ & $\begin{array}{r}-.053 \\
-10.454 \\
-.118 \\
-.679\end{array}$ & $\begin{array}{r}-.053 \\
-10.454 \\
-.118 \\
-1.153\end{array}$ & $\begin{array}{r}-.053 \\
-10.454 \\
-. .118 \\
-.679\end{array}$ & $\begin{array}{r}-.059 \\
-10.454 \\
--.178 \\
-1.497\end{array}$ \\
\hline $\begin{array}{l}8 \\
8 \\
8 \\
8 \\
8\end{array}$ & $\begin{array}{l}14 \\
14 \\
14 \\
14 \\
14\end{array}$ & $\begin{array}{l}20 \\
23 \\
25 \\
26 \\
28\end{array}$ & $\begin{array}{r}-.370 \\
-1.850 \\
-1.230 \\
-.950 \\
-.610\end{array}$ & $\begin{array}{r}-.260 \\
-1.330 \\
-2.148 \\
-1.621 \\
-.892\end{array}$ & $\begin{array}{r}-.260 \\
-1.330 \\
-2.347 \\
-1.771 \\
-1.816\end{array}$ & $\begin{array}{r}-.260 \\
-1.330 \\
-2.148 \\
-1.621 \\
-.892\end{array}$ & $\begin{array}{r}-.327 \\
-1.418 \\
-3.076 \\
-2.321 \\
-2.347\end{array}$ \\
\hline $\begin{array}{l}8 \\
8 \\
8 \\
8 \\
8\end{array}$ & $\begin{array}{l}14 \\
14 \\
14 \\
15 \\
15\end{array}$ & $\begin{array}{r}31 \\
33 \\
49 \\
6 \\
8\end{array}$ & $\begin{array}{r}-1.150 \\
-1.760 \\
-.330 \\
-.800 \\
-.050\end{array}$ & $\begin{array}{r}-.148 \\
-3.691 \\
-3.362 \\
-1.036 \\
-.023\end{array}$ & $\begin{array}{r}-.152 \\
-4.627 \\
-5.936 \\
-1.496 \\
-.023\end{array}$ & $\begin{array}{r}-.148 \\
-3.691 \\
-3.362 \\
-1.036 \\
-.023\end{array}$ & $\begin{array}{r}-.223 \\
-5.716 \\
-7.905 \\
-1.990 \\
-.034\end{array}$ \\
\hline $\begin{array}{l}8 \\
8 \\
8 \\
8 \\
8\end{array}$ & $\begin{array}{l}15 \\
15 \\
15 \\
15 \\
15\end{array}$ & $\begin{array}{l}12 \\
15 \\
21 \\
23 \\
27\end{array}$ & $\begin{array}{l}-.360 \\
-. \\
-.840 \\
-. \\
-.590\end{array}$ & $\begin{array}{r}-2.175 \\
-.448 \\
-.693 \\
-.603 \\
-.617\end{array}$ & $\begin{array}{r}-3.419 \\
-.970 \\
-.693 \\
-.603 \\
-.617\end{array}$ & $\begin{array}{r}-2.342 \\
-.448 \\
-.693 \\
-.603 \\
-.617\end{array}$ & $\begin{array}{r}-4.454 \\
-1.133 \\
-.874 \\
-.643 \\
-.777\end{array}$ \\
\hline $\begin{array}{l}8 \\
8 \\
8 \\
8 \\
8\end{array}$ & $\begin{array}{l}15 \\
15 \\
15 \\
15 \\
15\end{array}$ & $\begin{array}{l}28 \\
30 \\
31 \\
32 \\
33\end{array}$ & $\begin{array}{l}-.360 \\
-.260 \\
-.110 \\
-.660 \\
-.150\end{array}$ & $\begin{array}{c}-- \\
\overline{-} \\
-.123 \\
-.059\end{array}$ & $\begin{array}{c}-- \\
\overline{-} \\
-.248 \\
-.059\end{array}$ & $\begin{array}{c}-- \\
-- \\
-\overline{-} \\
-.123 \\
-.059\end{array}$ & $\begin{array}{c}-- \\
-- \\
-.288 \\
-.089\end{array}$ \\
\hline $\begin{array}{l}8 \\
8 \\
8 \\
8 \\
8\end{array}$ & $\begin{array}{l}15 \\
15 \\
15 \\
16 \\
16\end{array}$ & $\begin{array}{r}34 \\
37 \\
39 \\
7 \\
11\end{array}$ & $\begin{array}{l}-.420 \\
-.750 \\
-.100 \\
-.020 \\
-.320\end{array}$ & $\begin{array}{r}-.201 \\
-1.156 \\
-.129 \\
-- \\
-.337\end{array}$ & $\begin{array}{r}-.231 \\
-1.327 \\
-.149 \\
-\overline{-.177}\end{array}$ & $\begin{array}{r}-.201 \\
-1.156 \\
-.129 \\
-. .5 \\
-.129\end{array}$ & $\begin{array}{c}-.300 \\
-1.724 \\
-.193 \\
-.212\end{array}$ \\
\hline $\begin{array}{l}8 \\
8 \\
8 \\
8 \\
8\end{array}$ & $\begin{array}{l}16 \\
16 \\
16 \\
16 \\
16\end{array}$ & $\begin{array}{l}20 \\
22 \\
27 \\
28 \\
29\end{array}$ & $\begin{array}{r}-1.490 \\
-.210 \\
-.210 \\
-.770 \\
-.790\end{array}$ & $\begin{array}{r}-- \\
-.057 \\
-.192 \\
-.119 \\
--\end{array}$ & $\begin{array}{c}-- \\
-.057 \\
-.192 \\
-.207 \\
-.\end{array}$ & $\begin{array}{l}-- \\
-.057 \\
-.192 \\
-.119 \\
--\end{array}$ & $\begin{array}{l}--\overline{-} \\
-.072 \\
-.242 \\
-.240 \\
--\end{array}$ \\
\hline $\begin{array}{l}8 \\
8 \\
8 \\
8 \\
8\end{array}$ & $\begin{array}{l}16 \\
16 \\
16 \\
16 \\
16\end{array}$ & $\begin{array}{l}31 \\
33 \\
35 \\
37 \\
41\end{array}$ & $\begin{array}{r}-.320 \\
-1.680 \\
-.140 \\
-.150 \\
-.670\end{array}$ & $\begin{array}{l}-.248 \\
-.705 \\
-.326 \\
-.089 \\
-.010\end{array}$ & $\begin{array}{l}-.248 \\
-.877 \\
-.375 \\
-.102 \\
-.010\end{array}$ & $\begin{array}{l}-.248 \\
-.705 \\
-.326 \\
-.089 \\
-.010\end{array}$ & $\begin{array}{r}-.313 \\
-1.074 \\
-.488 \\
-.133 \\
-.015\end{array}$ \\
\hline
\end{tabular}


Appendix B.--Withdrawals simulated at each cell

for all simulations--Continued

\begin{tabular}{|c|c|c|c|c|c|c|c|}
\hline $\begin{array}{l}\text { Model } \\
\text { layer }\end{array}$ & $\begin{array}{c}\text { Cell } \\
\text { column }\end{array}$ & $\begin{array}{l}\text { Cell } \\
\text { row }\end{array}$ & $\begin{array}{l}\text { Calibration } \\
\text { simulation } \\
(1970-79)\end{array}$ & $\begin{array}{c}\text { Scenario } \\
1\end{array}$ & $\underset{2}{\text { Scenario }}$ & $\underset{3}{\text { Scenario. }}$ & $\underset{4}{\text { Scenario }}$ \\
\hline $\begin{array}{l}8 \\
8 \\
8 \\
8 \\
8\end{array}$ & $\begin{array}{l}17 \\
17 \\
17 \\
17 \\
17\end{array}$ & $\begin{array}{r}6 \\
11 \\
16 \\
17 \\
22\end{array}$ & $\begin{array}{r}-0.060 \\
-.410 \\
-.790 \\
-.440 \\
-.140\end{array}$ & $\begin{array}{c}-0.049 \\
-1.780 \\
-1.658 \\
-.289 \\
--\end{array}$ & $\begin{array}{r}-0.049 \\
-.816 \\
-1.671 \\
-.291 \\
--\end{array}$ & $\begin{array}{r}-0.049 \\
-.551 \\
-1.658 \\
-.289 \\
--\end{array}$ & $\begin{array}{c}-0.073 \\
-1.001 \\
-2.247 \\
-.392 \\
--\end{array}$ \\
\hline $\begin{array}{l}8 \\
8 \\
8 \\
8 \\
8\end{array}$ & $\begin{array}{l}17 \\
17 \\
17 \\
17 \\
17\end{array}$ & $\begin{array}{l}32 \\
34 \\
35 \\
36 \\
39\end{array}$ & $\begin{array}{r}-.250 \\
-1.700 \\
-.450 \\
-1.090 \\
-1.450\end{array}$ & $\begin{array}{r}-- \\
-1.857 \\
-.504 \\
-1.741 \\
-2.869\end{array}$ & $\begin{array}{r}-- \\
-2.136 \\
-.567 \\
-2.002 \\
-3.299\end{array}$ & $\begin{array}{r}-- \\
-1.857 \\
-.504 \\
-1.741 \\
-2.869\end{array}$ & $\begin{array}{r}-- \\
-2.775 \\
-.753 \\
-2.602 \\
-4.288\end{array}$ \\
\hline $\begin{array}{l}8 \\
8 \\
8 \\
8 \\
8\end{array}$ & $\begin{array}{l}17 \\
17 \\
17 \\
17 \\
18\end{array}$ & $\begin{array}{r}42 \\
45 \\
46 \\
55 \\
7\end{array}$ & $\begin{array}{r}-1.880 \\
-.700 \\
-.640 \\
-.040 \\
-.010\end{array}$ & $\begin{array}{c}-23.124 \\
-.084 \\
-.257 \\
-- \\
-.499\end{array}$ & $\begin{array}{r}-27.853 \\
-.084 \\
-.257 \\
-- \\
-2.137\end{array}$ & $\begin{array}{c}-23.124 \\
-.084 \\
-.257 \\
-- \\
-1.028\end{array}$ & $\begin{array}{c}-35.955 \\
-.090 \\
-.324 \\
-- \\
-2.980\end{array}$ \\
\hline $\begin{array}{l}8 \\
8 \\
8 \\
8 \\
8\end{array}$ & $\begin{array}{l}18 \\
18 \\
18 \\
18 \\
18\end{array}$ & $\begin{array}{l}12 \\
13 \\
18 \\
25 \\
30\end{array}$ & $\begin{array}{r}-- \\
-.690 \\
-.550 \\
-.340 \\
--\end{array}$ & $\begin{array}{l}-.034 \\
-.- \\
-.301 \\
-.0 \\
-.095\end{array}$ & $\begin{array}{c}-.041 \\
-- \\
-.304 \\
-- \\
-.095\end{array}$ & $\begin{array}{c}-.034 \\
-- \\
-.301 \\
-- \\
-.095\end{array}$ & $\begin{array}{c}-.053 \\
-- \\
-.408 \\
--. \\
-.143\end{array}$ \\
\hline $\begin{array}{l}8 \\
8 \\
8 \\
8 \\
8\end{array}$ & $\begin{array}{l}18 \\
18 \\
18 \\
18 \\
18\end{array}$ & $\begin{array}{l}34 \\
36 \\
37 \\
38 \\
40\end{array}$ & $\begin{array}{l}-.080 \\
-.170 \\
-.840 \\
-.910 \\
-.680\end{array}$ & $\begin{array}{l}-.033 \\
-.203 \\
-.558 \\
-.135 \\
-.280\end{array}$ & $\begin{array}{l}-.038 \\
-.233 \\
-.558 \\
-.155 \\
-.280\end{array}$ & $\begin{array}{l}-.033 \\
-.203 \\
-.558 \\
-.135 \\
-.280\end{array}$ & $\begin{array}{l}-.050 \\
-.303 \\
-.594 \\
-.201 \\
-.353\end{array}$ \\
\hline $\begin{array}{l}8 \\
8 \\
8 \\
8 \\
8\end{array}$ & $\begin{array}{l}18 \\
18 \\
18 \\
18 \\
19\end{array}$ & $\begin{array}{l}44 \\
45 \\
46 \\
48 \\
13\end{array}$ & $\begin{array}{c}-.200 \\
-1.660 \\
-- \\
-.020 \\
-.290\end{array}$ & $\begin{array}{c}-- \\
-1.953 \\
-- \\
--\end{array}$ & $\begin{array}{c}-- \\
-- \\
-1.953 \\
-- \\
--\end{array}$ & $\begin{array}{c}-- \\
-- \\
-1.953 \\
-- \\
--\end{array}$ & $\begin{array}{c}-- \\
-\overline{-} \\
-2.462 \\
-- \\
--\end{array}$ \\
\hline $\begin{array}{l}8 \\
8 \\
8 \\
8 \\
8\end{array}$ & $\begin{array}{l}19 \\
19 \\
19 \\
19 \\
19\end{array}$ & $\begin{array}{l}18 \\
20 \\
29 \\
30 \\
38\end{array}$ & $\begin{array}{l}-.510 \\
-.020 \\
-.240 \\
-.180 \\
-.200\end{array}$ & $\begin{array}{c}-.244 \\
-- \\
-.255 \\
-- \\
--\end{array}$ & $\begin{array}{c}-.246 \\
-- \\
-.255 \\
-- \\
--\end{array}$ & $\begin{array}{c}-.244 \\
-. \\
-.255 \\
-- \\
--\end{array}$ & $\begin{array}{c}-.331 \\
-- \\
-.272 \\
-- \\
--\end{array}$ \\
\hline $\begin{array}{l}8 \\
8 \\
8 \\
8 \\
8\end{array}$ & $\begin{array}{l}19 \\
19 \\
19 \\
20 \\
20\end{array}$ & $\begin{array}{l}39 \\
42 \\
50 \\
12 \\
23\end{array}$ & $\begin{array}{c}-.070 \\
-.300 \\
-- \\
-1.390 \\
--\end{array}$ & $\begin{array}{r}-.044 \\
-.259 \\
.000 \\
-1.502 \\
-.158\end{array}$ & $\begin{array}{r}-.051 \\
-.259 \\
.000 \\
-1.794 \\
-.158\end{array}$ & $\begin{array}{r}-.044 \\
-.259 \\
.000 \\
-1.502 \\
-.158\end{array}$ & $\begin{array}{r}-.066 \\
-.276 \\
-.001 \\
-2.322 \\
-.200\end{array}$ \\
\hline $\begin{array}{l}8 \\
8 \\
8 \\
8 \\
8\end{array}$ & $\begin{array}{l}20 \\
20 \\
20 \\
20 \\
21\end{array}$ & $\begin{array}{r}28 \\
31 \\
41 \\
45 \\
6\end{array}$ & $\begin{array}{c}-.100 \\
-.090 \\
-- \\
-.040 \\
-.160\end{array}$ & $\begin{array}{c}-- \\
-.- \\
-.995 \\
-.825 \\
-.017\end{array}$ & $\begin{array}{c}-- \\
-- \\
-1.210 \\
-1.379 \\
-.017\end{array}$ & $\begin{array}{c}-- \\
-.- \\
-.995 \\
-.825 \\
-.017\end{array}$ & $\begin{array}{r}-- \\
-- \\
-1.520 \\
-1.793 \\
-.025\end{array}$ \\
\hline $\begin{array}{l}8 \\
8 \\
8 \\
8 \\
8\end{array}$ & $\begin{array}{l}21 \\
21 \\
21 \\
21 \\
21\end{array}$ & $\begin{array}{l}11 \\
12 \\
20 \\
23 \\
38\end{array}$ & $\begin{array}{r}-.160 \\
-2.490 \\
-.020 \\
-.610 \\
-.230\end{array}$ & $\begin{array}{c}-1.787 \\
-3.060 \\
-- \\
-.118 \\
-.140\end{array}$ & $\begin{array}{c}-2.136 \\
-3.656 \\
-- \\
-.118 \\
-.142\end{array}$ & $\begin{array}{c}-1.787 \\
-3.060 \\
-- \\
-.118 \\
-.140\end{array}$ & $\begin{array}{c}-2.763 \\
-4.731 \\
-- \\
-.148 \\
-.179\end{array}$ \\
\hline $\begin{array}{l}8 \\
8 \\
8 \\
8 \\
8\end{array}$ & $\begin{array}{l}21 \\
21 \\
21 \\
22 \\
22\end{array}$ & $\begin{array}{r}45 \\
46 \\
49 \\
7 \\
13\end{array}$ & $\begin{array}{c}-1.230 \\
-1.180 \\
-- \\
-1.330\end{array}$ & $\begin{array}{r}-- \\
-2.476 \\
-.004 \\
-.474 \\
-.041\end{array}$ & $\begin{array}{r}-- \\
-4.137 \\
-.004 \\
-5.231 \\
-.052\end{array}$ & $\begin{array}{r}-- \\
-2.476 \\
-.004 \\
-2.516 \\
-.041\end{array}$ & $\begin{array}{r}-- \\
-5.381 \\
-.006 \\
-7.219 \\
-.066\end{array}$ \\
\hline $\begin{array}{l}8 \\
8 \\
8 \\
8 \\
8\end{array}$ & $\begin{array}{l}22 \\
22 \\
22 \\
22 \\
22\end{array}$ & $\begin{array}{l}14 \\
17 \\
19 \\
20 \\
21\end{array}$ & $\begin{array}{l}-.210 \\
-.140 \\
-.290 \\
--.040\end{array}$ & $\begin{array}{c}-15.746 \\
-.107 \\
-- \\
-.412 \\
.-\end{array}$ & $\begin{array}{c}-31.246 \\
-.107 \\
-- \\
-.412 \\
-.-\end{array}$ & $\begin{array}{c}-15.746 \\
-.107 \\
-- \\
-.412 \\
-.-\end{array}$ & $\begin{array}{c}-42.098 \\
-.135 \\
-- \\
-.519 \\
--\end{array}$ \\
\hline
\end{tabular}


Appendix B.--Withdrawals simulated at each cell

for all simulations--Continued

\begin{tabular}{|c|c|c|c|c|c|c|c|}
\hline $\begin{array}{l}\text { Model } \\
\text { layer }\end{array}$ & $\begin{array}{l}\text { Cell } \\
\text { column }\end{array}$ & $\begin{array}{l}\text { Cell } \\
\text { row }\end{array}$ & $\begin{array}{l}\text { Calibration } \\
\text { simulation } \\
(1970-79)\end{array}$ & $\underset{1}{\text { Scenario }}$ & $\begin{array}{c}\text { Scenario } \\
2\end{array}$ & $\underset{3}{\text { Scenario }}$ & $\underset{4}{\text { Scenario }}$ \\
\hline $\begin{array}{l}8 \\
8 \\
8 \\
8 \\
8\end{array}$ & $\begin{array}{l}22 \\
22 \\
22 \\
22 \\
22\end{array}$ & $\begin{array}{l}22 \\
23 \\
24 \\
25 \\
28\end{array}$ & $\begin{array}{r}-0.680 \\
-3.120 \\
-.470 \\
-.070 \\
-.040\end{array}$ & $\begin{array}{c}-- \\
-2.556 \\
-- \\
-- \\
--\end{array}$ & $\begin{array}{c}-- \\
-4.359 \\
-- \\
-- \\
--\end{array}$ & $\begin{array}{c}-- \\
-2.556 \\
-- \\
-- \\
--\end{array}$ & $\begin{array}{c}-- \\
-4.993 \\
-- \\
-- \\
--\end{array}$ \\
\hline $\begin{array}{l}8 \\
8 \\
8 \\
8 \\
8\end{array}$ & $\begin{array}{l}22 \\
22 \\
22 \\
22 \\
22\end{array}$ & $\begin{array}{l}37 \\
45 \\
46 \\
47 \\
49\end{array}$ & $\begin{array}{r}-1.480 \\
-.710 \\
-1.660 \\
-.030 \\
-.040\end{array}$ & $\begin{array}{r}-1.082 \\
-.825 \\
-3.301 \\
-. \\
-.825\end{array}$ & $\begin{array}{c}-1.100 \\
-1.379 \\
-5.515 \\
-- \\
-1.379\end{array}$ & $\begin{array}{r}-1.082 \\
-.825 \\
-3.301 \\
-- \\
-.825\end{array}$ & $\begin{array}{c}-1.477 \\
-1.793 \\
-7.174 \\
-- \\
-1.793\end{array}$ \\
\hline $\begin{array}{l}8 \\
8 \\
8 \\
8 \\
8\end{array}$ & $\begin{array}{l}23 \\
23 \\
23 \\
23 \\
23\end{array}$ & $\begin{array}{l}11 \\
14 \\
16 \\
19 \\
20\end{array}$ & $\begin{array}{r}-.070 \\
-.680 \\
.000 \\
-.710 \\
-.730\end{array}$ & $\begin{array}{c}-.025 \\
-.- \\
-.859 \\
--\end{array}$ & $\begin{array}{c}-.025 \\
-- \\
-- \\
-.859 \\
--\end{array}$ & $\begin{array}{c}-.025 \\
-- \\
-- \\
-.859 \\
--\end{array}$ & $\begin{array}{c}-.031 \\
-- \\
-- \\
-1.083 \\
--\end{array}$ \\
\hline $\begin{array}{l}8 \\
8 \\
8 \\
8 \\
8\end{array}$ & $\begin{array}{l}23 \\
23 \\
23 \\
23 \\
23\end{array}$ & $\begin{array}{l}22 \\
23 \\
24 \\
27 \\
37\end{array}$ & $\begin{array}{r}-.530 \\
-3.780 \\
-3.030 \\
-.130 \\
-4.560\end{array}$ & $\begin{array}{r}-.368 \\
-9.109 \\
-.135 \\
-\overline{-5.158}\end{array}$ & $\begin{array}{r}-.368 \\
-13.522 \\
-.135 \\
-- \\
-5.244\end{array}$ & $\begin{array}{r}-.368 \\
-9.109 \\
-.135 \\
--5 \\
-5.158\end{array}$ & $\begin{array}{r}-.392 \\
-15.142 \\
-.144 \\
-.0 \\
-7.025\end{array}$ \\
\hline $\begin{array}{l}8 \\
8 \\
8 \\
8 \\
8\end{array}$ & $\begin{array}{l}23 \\
23 \\
24 \\
24 \\
24\end{array}$ & $\begin{array}{l}45 \\
50 \\
11 \\
15 \\
16\end{array}$ & $\begin{array}{l}-.750 \\
-- \\
-.440 \\
-.300 \\
-.190\end{array}$ & $\begin{array}{r}-1.651 \\
-.862 \\
-.680 \\
-.157 \\
--\end{array}$ & $\begin{array}{c}-2.757 \\
-1.197 \\
-.848 \\
-.157 \\
--\end{array}$ & $\begin{array}{r}-1.651 \\
-.862 \\
-.680 \\
-.157 \\
--\end{array}$ & $\begin{array}{c}-3.587 \\
-1.592 \\
-1.088 \\
-.198 \\
--\end{array}$ \\
\hline $\begin{array}{l}8 \\
8 \\
8 \\
8 \\
8\end{array}$ & $\begin{array}{l}24 \\
24 \\
24 \\
24 \\
24\end{array}$ & $\begin{array}{l}21 \\
22 \\
24 \\
27 \\
45\end{array}$ & $\begin{array}{l}-.530 \\
-.380 \\
-.530 \\
-.810 \\
-.110\end{array}$ & $\begin{array}{c}-- \\
-- \\
-\overline{-} \\
-.220\end{array}$ & $\begin{array}{c}-- \\
\overline{--} \\
-\overline{-} \\
-.220\end{array}$ & $\begin{array}{c}-- \\
-- \\
-- \\
-.220\end{array}$ & $\begin{array}{c}-- \\
-- \\
-\overline{-} \\
-.278\end{array}$ \\
\hline $\begin{array}{l}8 \\
8 \\
8 \\
8 \\
8\end{array}$ & $\begin{array}{l}25 \\
25 \\
25 \\
25 \\
25\end{array}$ & $\begin{array}{l}12 \\
17 \\
22 \\
24 \\
44\end{array}$ & $\begin{array}{r}-1.700 \\
-.150 \\
-.300 \\
-.110 \\
-.110\end{array}$ & $\begin{array}{c}-2.053 \\
-- \\
-.129 \\
-.056\end{array}$ & $\begin{array}{c}-2.561 \\
-. \\
-.129 \\
-.056\end{array}$ & $\begin{array}{c}-2.053 \\
-- \\
-.129 \\
-.056\end{array}$ & $\begin{array}{c}-3.286 \\
-- \\
-.162 \\
-.070 \\
-.070\end{array}$ \\
\hline $\begin{array}{l}8 \\
8 \\
8 \\
8 \\
8\end{array}$ & $\begin{array}{l}26 \\
26 \\
26 \\
26 \\
26\end{array}$ & $\begin{array}{l}10 \\
11 \\
26 \\
48 \\
52\end{array}$ & $\begin{array}{l}-.050 \\
-.060 \\
-.050 \\
-.460 \\
.000\end{array}$ & $\begin{array}{l}-.114 \\
-.034 \\
--178 \\
-.1709 \\
-.909\end{array}$ & $\begin{array}{r}-.114 \\
-.042 \\
-- \\
-.253 \\
-1.439\end{array}$ & $\begin{array}{l}-.114 \\
-.034 \\
-- \\
-.178 \\
-.909\end{array}$ & $\begin{array}{c}-.154 \\
-.054 \\
-- \\
-.338 \\
-1.906\end{array}$ \\
\hline $\begin{array}{l}8 \\
8 \\
8 \\
8 \\
8\end{array}$ & $\begin{array}{l}27 \\
27 \\
27 \\
27 \\
27\end{array}$ & $\begin{array}{r}9 \\
21 \\
25 \\
27 \\
28\end{array}$ & $\begin{array}{l}-.370 \\
-.040 \\
-.040 \\
-.150 \\
-.070\end{array}$ & $\begin{array}{c}-.717 \\
-- \\
-- \\
--\end{array}$ & $\begin{array}{c}-.931 \\
-- \\
-- \\
-- \\
--\end{array}$ & $\begin{array}{c}-.717 \\
-- \\
-- \\
--\end{array}$ & $\begin{array}{c}-1.230 \\
=- \\
-- \\
-- \\
--\end{array}$ \\
\hline $\begin{array}{l}8 \\
8 \\
8 \\
8 \\
8\end{array}$ & $\begin{array}{l}27 \\
27 \\
28 \\
28 \\
28\end{array}$ & $\begin{array}{l}44 \\
48 \\
14 \\
20 \\
21\end{array}$ & $\begin{array}{l}-.040 \\
-.350 \\
-.260 \\
-.140 \\
-.120\end{array}$ & $\begin{array}{c}-- \\
-.136 \\
-.757 \\
-1.098 \\
--\end{array}$ & $\begin{array}{c}-- \\
-.193 \\
-.818 \\
-1.098 \\
--\end{array}$ & $\begin{array}{r}-.- \\
-.136 \\
-.757 \\
-1.098 \\
--\end{array}$ & $\begin{array}{c}-- \\
-.258 \\
-1.097 \\
-1.384 \\
--\end{array}$ \\
\hline $\begin{array}{l}8 \\
8 \\
8 \\
8 \\
8\end{array}$ & $\begin{array}{l}28 \\
28 \\
28 \\
28 \\
28\end{array}$ & $\begin{array}{l}23 \\
27 \\
30 \\
40 \\
47\end{array}$ & $\begin{array}{r}-.060 \\
-.680 \\
.000 \\
-.030 \\
-.370\end{array}$ & $\begin{array}{c}-- \\
-1.040 \\
-- \\
-.129 \\
-2.965\end{array}$ & $\begin{array}{c}-- \\
-1.040 \\
-\overline{129} \\
-.129 \\
-4.200\end{array}$ & $\begin{array}{c}-- \\
-1.040 \\
-\overline{129} \\
-.129 \\
-2.965\end{array}$ & $\begin{array}{c}-\overline{311} \\
-1 . \overline{1} \\
-.138 \\
-5.614\end{array}$ \\
\hline $\begin{array}{l}8 \\
8 \\
8 \\
8 \\
8\end{array}$ & $\begin{array}{l}29 \\
29 \\
29 \\
29 \\
29\end{array}$ & $\begin{array}{l}10 \\
13 \\
14 \\
15 \\
20\end{array}$ & $\begin{array}{r}-.310 \\
-2.130 \\
-.340 \\
-.490 \\
-1.260\end{array}$ & $\begin{array}{c}-.531 \\
-- \\
-- \\
-.060 \\
--\end{array}$ & $\begin{array}{c}-.531 \\
-- \\
-- \\
-.060 \\
--\end{array}$ & $\begin{array}{c}-.531 \\
-- \\
-- \\
-.060 \\
--\end{array}$ & $\begin{array}{c}-.716 \\
-- \\
-.076 \\
--\end{array}$ \\
\hline
\end{tabular}




\section{Appendix B.--Withdrawals simulated at each cell \\ for all simulations--Continued}

\begin{tabular}{|c|c|c|c|c|c|c|c|}
\hline $\begin{array}{l}\text { Model } \\
\text { layer }\end{array}$ & $\begin{array}{c}\text { Cell } \\
\text { colum }\end{array}$ & $\begin{array}{l}\text { Cell } \\
\text { row }\end{array}$ & $\begin{array}{l}\text { Calibration } \\
\text { simulation } \\
(1970-79)\end{array}$ & $\begin{array}{c}\text { Scenario } \\
1\end{array}$ & $\begin{array}{c}\text { Scenario } \\
2\end{array}$ & $\begin{array}{c}\text { Scenario } \\
3\end{array}$ & $\underset{4}{S c e n a r i o}$ \\
\hline $\begin{array}{l}8 \\
8 \\
8 \\
8 \\
8\end{array}$ & $\begin{array}{l}29 \\
29 \\
29 \\
29 \\
29\end{array}$ & $\begin{array}{l}21 \\
24 \\
25 \\
40 \\
52\end{array}$ & $\begin{array}{r}-0.130 \\
-.670 \\
-.200 \\
-.130 \\
-.350\end{array}$ & $\begin{array}{r}-- \\
-0.303 \\
-- \\
-.396 \\
-2.319\end{array}$ & $\begin{array}{c}-- \\
-0.303 \\
-- \\
-.396 \\
-3.221\end{array}$ & $\begin{array}{c}-- \\
-0.303 \\
-- \\
-.396 \\
-2.319\end{array}$ & $\begin{array}{c}-- \\
-0.381 \\
-\overline{-} \\
-.423 \\
-4.286\end{array}$ \\
\hline $\begin{array}{l}8 \\
8 \\
8 \\
8 \\
8\end{array}$ & $\begin{array}{l}30 \\
30 \\
30 \\
30 \\
30\end{array}$ & $\begin{array}{l}16 \\
19 \\
20 \\
24 \\
25\end{array}$ & $\begin{array}{r}-1.820 \\
-.060 \\
-.390 \\
-.420 \\
-.050\end{array}$ & $\begin{array}{c}-- \\
-\overline{-307} \\
-\overline{-} \\
-.059\end{array}$ & $\begin{array}{c}-- \\
-. \overline{307} \\
-.059\end{array}$ & $\begin{array}{c}-- \\
-\overline{307} \\
-. \overline{-0} \\
-.059\end{array}$ & $\begin{array}{c}-\overline{-} \\
-. \overline{387} \\
-\overline{0} \\
-.074\end{array}$ \\
\hline $\begin{array}{l}8 \\
8 \\
8 \\
8 \\
8\end{array}$ & $\begin{array}{l}30 \\
30 \\
31 \\
31 \\
31\end{array}$ & $\begin{array}{l}44 \\
49 \\
10 \\
11 \\
18\end{array}$ & $\begin{array}{l}-.170 \\
-.620 \\
-.350 \\
-.380 \\
-.280\end{array}$ & $\begin{array}{r}-1.190 \\
-2.679 \\
-.325 \\
-.486 \\
--\end{array}$ & $\begin{array}{c}-1.847 \\
-3.721 \\
-.325 \\
-.486 \\
--\end{array}$ & $\begin{array}{r}-1.190 \\
-2.679 \\
-.325 \\
-.486 \\
--\end{array}$ & $\begin{array}{r}-2.411 \\
-4.951 \\
-.438 \\
-.655 \\
--\end{array}$ \\
\hline $\begin{array}{l}8 \\
8 \\
8 \\
8 \\
8\end{array}$ & $\begin{array}{l}31 \\
31 \\
31 \\
31 \\
32\end{array}$ & $\begin{array}{l}19 \\
37 \\
38 \\
48 \\
18\end{array}$ & $\begin{array}{r}-.040 \\
-1.030 \\
-1.980 \\
-.610 \\
-.220\end{array}$ & $\begin{array}{r}-- \\
-.973 \\
-1.016 \\
-.513 \\
-.202\end{array}$ & $\begin{array}{r}--- \\
-.973 \\
-1.016 \\
-.513 \\
-.202\end{array}$ & $\begin{array}{r}--- \\
-.973 \\
-1.016 \\
-.513 \\
-.202\end{array}$ & $\begin{array}{r}-- \\
-1.038 \\
-1.281 \\
-.647 \\
-.255\end{array}$ \\
\hline $\begin{array}{l}8 \\
8 \\
8 \\
8 \\
8\end{array}$ & $\begin{array}{l}32 \\
32 \\
32 \\
32 \\
32\end{array}$ & $\begin{array}{l}20 \\
26 \\
28 \\
38 \\
48\end{array}$ & $\begin{array}{r}-- \\
-.660 \\
-.090 \\
-\overline{810}\end{array}$ & $\begin{array}{c}-.034 \\
-- \\
-1.062 \\
-5.888\end{array}$ & $\begin{array}{c}-.034 \\
-- \\
-- \\
-1.062 \\
-8.340\end{array}$ & $\begin{array}{c}-.034 \\
-- \\
-1.062 \\
-5.888\end{array}$ & $\begin{array}{c}-.036 \\
-- \\
-1.339 \\
-11.149\end{array}$ \\
\hline $\begin{array}{l}8 \\
8 \\
8 \\
8 \\
8\end{array}$ & $\begin{array}{l}32 \\
33 \\
33 \\
33 \\
33\end{array}$ & $\begin{array}{l}50 \\
13 \\
20 \\
26 \\
27\end{array}$ & $\begin{array}{r}-.050 \\
-.020 \\
-.080 \\
-1.200 \\
-8.120\end{array}$ & $\begin{array}{r}-.030 \\
-.056 \\
-.005 \\
-1.639 \\
-6.105\end{array}$ & $\begin{array}{r}-.030 \\
-.056 \\
-.005 \\
-1.639 \\
-6.105\end{array}$ & $\begin{array}{r}-.030 \\
-.056 \\
-.005 \\
-1.639 \\
-6.105\end{array}$ & $\begin{array}{r}-.044 \\
-.071 \\
-.007 \\
-2.066 \\
-7.696\end{array}$ \\
\hline $\begin{array}{l}8 \\
8 \\
8 \\
8 \\
8\end{array}$ & $\begin{array}{l}33 \\
33 \\
34 \\
34 \\
34\end{array}$ & $\begin{array}{r}33 \\
48 \\
9 \\
11 \\
20\end{array}$ & $\begin{array}{r}-.110 \\
-.240 \\
-.230 \\
-2.560 \\
--\end{array}$ & $\begin{array}{r}-.059 \\
-3.236 \\
-.151 \\
-.864 \\
-.069\end{array}$ & $\begin{array}{r}-.059 \\
-4.583 \\
-.151 \\
-.864 \\
-.069\end{array}$ & $\begin{array}{r}-.059 \\
-3.236 \\
-.151 \\
-.864 \\
-.069\end{array}$ & $\begin{array}{r}-.062 \\
-6.127 \\
-.203 \\
-1.089 \\
-.074\end{array}$ \\
\hline $\begin{array}{l}8 \\
8 \\
8 \\
8 \\
8\end{array}$ & $\begin{array}{l}34 \\
34 \\
34 \\
34 \\
34\end{array}$ & $\begin{array}{l}25 \\
26 \\
27 \\
32 \\
36\end{array}$ & $\begin{array}{l}-.320 \\
-.930 \\
-.180 \\
-.150 \\
-.570\end{array}$ & $\begin{array}{c}-- \\
-\overline{-} \\
-.212 \\
--\end{array}$ & $\begin{array}{c}-- \\
-\overline{-} \\
-.212 \\
-- \\
--\end{array}$ & $\begin{array}{c}-- \\
-\overline{-} \\
-. \overline{-} \\
--\end{array}$ & $\begin{array}{c}-- \\
-\overline{-} \\
-.226 \\
-- \\
--\end{array}$ \\
\hline $\begin{array}{l}8 \\
8 \\
8 \\
8 \\
8\end{array}$ & $\begin{array}{l}34 \\
34 \\
34 \\
35 \\
35\end{array}$ & $\begin{array}{r}41 \\
42 \\
51 \\
9 \\
12\end{array}$ & $\begin{array}{r}-.070 \\
-2.220 \\
-.450 \\
-. \\
-.430\end{array}$ & $\begin{array}{r}-.003 \\
-19.149 \\
-.922 \\
-.016 \\
-.020\end{array}$ & $\begin{array}{r}-.003 \\
-29.716 \\
-2.896 \\
-.016 \\
-.020\end{array}$ & $\begin{array}{r}-.003 \\
-19.149 \\
-.922 \\
-.016 \\
-.020\end{array}$ & $\begin{array}{r}-.003 \\
-38.780 \\
-3.792 \\
-.022 \\
-.025\end{array}$ \\
\hline $\begin{array}{l}8 \\
8 \\
8 \\
8 \\
8\end{array}$ & $\begin{array}{l}35 \\
35 \\
35 \\
35 \\
35\end{array}$ & $\begin{array}{l}14 \\
24 \\
27 \\
28 \\
56\end{array}$ & $\begin{array}{l}-.100 \\
-. \overline{150} \\
-.010\end{array}$ & $\begin{array}{c}-- \\
-8.420 \\
-- \\
-.110 \\
--\end{array}$ & $\begin{array}{c}-- \\
-16.287 \\
-- \\
-.110 \\
--\end{array}$ & $\begin{array}{c}-- \\
-8.420 \\
-- \\
-.110 \\
--\end{array}$ & $\begin{array}{c}-\overline{-} \\
-18.871 \\
-\overline{139} \\
--\end{array}$ \\
\hline $\begin{array}{l}8 \\
8 \\
8 \\
8 \\
8\end{array}$ & $\begin{array}{l}36 \\
36 \\
36 \\
36 \\
36\end{array}$ & $\begin{array}{l}15 \\
25 \\
27 \\
34 \\
35\end{array}$ & $\begin{array}{l}-.010 \\
-.870 \\
-.070 \\
-.240\end{array}$ & $\begin{array}{c}-- \\
-- \\
-.026 \\
-.460\end{array}$ & $\begin{array}{c}-- \\
-- \\
-.026 \\
-.460\end{array}$ & $\begin{array}{c}-- \\
-- \\
-.026 \\
-.460\end{array}$ & $\begin{array}{c}-- \\
-- \\
-.033 \\
-.580\end{array}$ \\
\hline $\begin{array}{l}8 \\
8 \\
8 \\
8 \\
8\end{array}$ & $\begin{array}{l}36 \\
36 \\
36 \\
36 \\
36\end{array}$ & $\begin{array}{l}38 \\
40 \\
46 \\
53 \\
56\end{array}$ & $\begin{array}{r}-- \\
-.120 \\
-.040 \\
-.020 \\
-.010\end{array}$ & $\begin{array}{l}-.029 \\
-.533 \\
-.085 \\
-.023 \\
-.062\end{array}$ & $\begin{array}{l}-.029 \\
-.533 \\
-.085 \\
-.023 \\
-.062\end{array}$ & $\begin{array}{l}-.029 \\
-.533 \\
-.085 \\
-.023 \\
-.062\end{array}$ & $\begin{array}{l}-.043 \\
-.672 \\
-.128 \\
-.035 \\
-.094\end{array}$ \\
\hline
\end{tabular}


Appendix B.--Withdrawals simulated at each cell

for all simulations--Continued

\begin{tabular}{|c|c|c|c|c|c|c|c|}
\hline $\begin{array}{l}\text { Model } \\
\text { layer }\end{array}$ & $\begin{array}{c}\text { Cell } \\
\text { column }\end{array}$ & $\begin{array}{l}\text { Cell } \\
\text { row }\end{array}$ & $\begin{array}{l}\text { Calibration } \\
\text { simulation } \\
(1970-79)\end{array}$ & $\underset{1}{\text { Scenario }}$ & $\underset{2}{\text { Scenario }}$ & $\underset{3}{\text { Scenario }}$ & Scenario \\
\hline $\begin{array}{l}8 \\
8 \\
8 \\
8 \\
8\end{array}$ & $\begin{array}{l}37 \\
37 \\
37 \\
37 \\
37\end{array}$ & $\begin{array}{r}8 \\
13 \\
15 \\
34 \\
48\end{array}$ & $\begin{array}{r}-0.280 \\
-.210 \\
-.010 \\
-.560 \\
-.130\end{array}$ & $\begin{array}{c}-0.224 \\
-.059 \\
-1.707 \\
-- \\
-.020\end{array}$ & $\begin{array}{c}-0.224 \\
-.059 \\
-2.643 \\
-- \\
-.077\end{array}$ & $\begin{array}{c}-0.224 \\
-.059 \\
-1.707 \\
-- \\
-.020\end{array}$ & $\begin{array}{c}-0.302 \\
-.062 \\
-3.531 \\
-- \\
-.100\end{array}$ \\
\hline $\begin{array}{l}8 \\
8 \\
8 \\
8 \\
8\end{array}$ & $\begin{array}{l}37 \\
37 \\
37 \\
38 \\
38\end{array}$ & $\begin{array}{l}52 \\
53 \\
57 \\
11 \\
12\end{array}$ & $\begin{array}{r}-1.850 \\
-.210 \\
-.010 \\
-.530 \\
-1.330\end{array}$ & $\begin{array}{c}-- \\
-.352 \\
-.004 \\
-- \\
-3.922\end{array}$ & $\begin{array}{c}-- \\
-1.105 \\
-.004 \\
-- \\
-5.522\end{array}$ & $\begin{array}{c}-- \\
-.352 \\
-.004 \\
-- \\
-3.922\end{array}$ & $\begin{array}{c}-- \\
-1.447 \\
-.006 \\
-- \\
-7.361\end{array}$ \\
\hline $\begin{array}{l}8 \\
8 \\
8 \\
8 \\
8\end{array}$ & $\begin{array}{l}38 \\
38 \\
38 \\
39 \\
39\end{array}$ & $\begin{array}{r}14 \\
48 \\
56 \\
2 \\
24\end{array}$ & $\begin{array}{r}-.010 \\
-.060 \\
.000 \\
-- \\
-.060\end{array}$ & $\begin{array}{l}-\overline{-} \\
-.512 \\
-- \\
-.709 \\
--\end{array}$ & $\begin{array}{c}-- \\
-1.994 \\
-- \\
-.709 \\
--\end{array}$ & $\begin{array}{c}-- \\
-.512 \\
-- \\
-.709 \\
--\end{array}$ & $\begin{array}{c}-- \\
-2.594 \\
-- \\
-.756 \\
--\end{array}$ \\
\hline $\begin{array}{l}8 \\
8 \\
8 \\
8 \\
8\end{array}$ & $\begin{array}{l}39 \\
39 \\
39 \\
39 \\
39\end{array}$ & $\begin{array}{l}32 \\
35 \\
39 \\
42 \\
47\end{array}$ & $\begin{array}{r}-2.290 \\
-.090 \\
-.190 \\
-.010 \\
-.160\end{array}$ & $\begin{array}{l}-- \\
-.079 \\
-- \\
-.053 \\
-.145\end{array}$ & $\begin{array}{l}-- \\
-.079 \\
-- \\
-.082 \\
-.145\end{array}$ & $\begin{array}{l}-- \\
-.079 \\
-- \\
-.053 \\
-.145\end{array}$ & $\begin{array}{c}-- \\
-.084 \\
-- \\
-.107 \\
-.182\end{array}$ \\
\hline $\begin{array}{l}8 \\
8 \\
8 \\
8 \\
8\end{array}$ & $\begin{array}{l}39 \\
39 \\
40 \\
40 \\
40\end{array}$ & $\begin{array}{r}48 \\
53 \\
2 \\
12 \\
15\end{array}$ & $\begin{array}{r}-.210 \\
.000 \\
-- \\
-.030 \\
-.230\end{array}$ & $\begin{array}{c}-.442 \\
-.037 \\
-.565 \\
-- \\
--\end{array}$ & $\begin{array}{r}-1.720 \\
-.037 \\
-.565 \\
-- \\
--\end{array}$ & $\begin{array}{c}-.442 \\
-.037 \\
-.565 \\
-- \\
--\end{array}$ & $\begin{array}{c}-2.238 \\
-.055 \\
-.603 \\
-- \\
--\end{array}$ \\
\hline $\begin{array}{l}8 \\
8 \\
8 \\
8 \\
8\end{array}$ & $\begin{array}{l}40 \\
40 \\
40 \\
40 \\
40\end{array}$ & $\begin{array}{l}19 \\
29 \\
30 \\
31 \\
32\end{array}$ & $\begin{array}{l}-.030 \\
-.010 \\
-.860 \\
-.130 \\
-.220\end{array}$ & $\begin{array}{r}-.027 \\
-.559 \\
-- \\
-.093 \\
-3.559\end{array}$ & $\begin{array}{r}-.027 \\
-.559 \\
-- \\
-.093 \\
-5.023\end{array}$ & $\begin{array}{r}-.027 \\
-.559 \\
-- \\
-.093 \\
-3.559\end{array}$ & $\begin{array}{c}-.034 \\
-.596 \\
-- \\
-.118 \\
-5.654\end{array}$ \\
\hline $\begin{array}{l}8 \\
8 \\
8 \\
8 \\
8\end{array}$ & $\begin{array}{l}40 \\
40 \\
40 \\
40 \\
41\end{array}$ & $\begin{array}{l}52 \\
53 \\
55 \\
56 \\
12\end{array}$ & $\begin{array}{c}-- \\
-.020 \\
-.020 \\
-.040 \\
--\end{array}$ & $\begin{array}{r}-.020 \\
-.027 \\
-- \\
-.143 \\
-1.838\end{array}$ & $\begin{array}{r}-.020 \\
-.027 \\
-- \\
-.143 \\
-1.865\end{array}$ & $\begin{array}{r}-.020 \\
-.027 \\
-- \\
-.143 \\
-1.838\end{array}$ & $\begin{array}{c}-.031 \\
-.041 \\
-- \\
-.214 \\
-2.506\end{array}$ \\
\hline $\begin{array}{l}8 \\
8 \\
8 \\
8 \\
8\end{array}$ & $\begin{array}{l}41 \\
41 \\
41 \\
41 \\
41\end{array}$ & $\begin{array}{l}15 \\
17 \\
27 \\
28 \\
29\end{array}$ & $\begin{array}{r}-- \\
-.040 \\
-.090 \\
-.410 \\
-.770\end{array}$ & $\begin{array}{c}-14.513 \\
-- \\
-.012 \\
-- \\
--\end{array}$ & $\begin{array}{c}-24.846 \\
-- \\
-.012 \\
-- \\
--\end{array}$ & $\begin{array}{c}-14.513 \\
-- \\
-.012 \\
-- \\
--\end{array}$ & $\begin{array}{c}-33.493 \\
-- \\
-.013 \\
-- \\
--\end{array}$ \\
\hline $\begin{array}{l}8 \\
8 \\
8 \\
8 \\
8\end{array}$ & $\begin{array}{l}41 \\
41 \\
41 \\
41 \\
42\end{array}$ & $\begin{array}{r}52 \\
53 \\
56 \\
57 \\
8\end{array}$ & $\begin{array}{l}-.050 \\
-.030 \\
-.060 \\
-.050 \\
--\end{array}$ & $\begin{array}{l}-.085 \\
-.058 \\
-.221 \\
-.051 \\
-.059\end{array}$ & $\begin{array}{l}-.085 \\
-.058 \\
-.221 \\
-.051 \\
-.165\end{array}$ & $\begin{array}{l}-.085 \\
-.058 \\
-.221 \\
-.051 \\
-.059\end{array}$ & $\begin{array}{l}-.127 \\
-.087 \\
-.331 \\
-.076 \\
-.192\end{array}$ \\
\hline $\begin{array}{l}8 \\
8 \\
8 \\
8 \\
8\end{array}$ & $\begin{array}{l}42 \\
42 \\
42 \\
42 \\
42\end{array}$ & $\begin{array}{l}13 \\
14 \\
16 \\
27 \\
28\end{array}$ & $\begin{array}{l}-.110 \\
-- \\
-- \\
-.700 \\
-.940\end{array}$ & $\begin{array}{r}-.204 \\
-29.027 \\
-.112 \\
-.956 \\
-.061\end{array}$ & $\begin{array}{r}-.207 \\
-49.693 \\
-.112 \\
-.956 \\
-.061\end{array}$ & $\begin{array}{r}-.204 \\
-29.027 \\
-.112 \\
-.956 \\
-.061\end{array}$ & $\begin{array}{r}-. .278 \\
-66.986 \\
-.120 \\
-1.019 \\
-.076\end{array}$ \\
\hline $\begin{array}{l}8 \\
8 \\
8 \\
8 \\
8\end{array}$ & $\begin{array}{l}42 \\
42 \\
42 \\
43 \\
43\end{array}$ & $\begin{array}{l}29 \\
30 \\
55 \\
25 \\
29\end{array}$ & $\begin{array}{r}-3.430 \\
-.200 \\
-.010 \\
-.010 \\
-.070\end{array}$ & $\begin{array}{r}-1.563 \\
-.402 \\
-.087 \\
-- \\
--\end{array}$ & $\begin{array}{c}-1.563 \\
-.402 \\
-.087 \\
-- \\
--\end{array}$ & $\begin{array}{c}-1.563 \\
-.402 \\
-.087 \\
-- \\
--\end{array}$ & $\begin{array}{c}-1.689 \\
-.428 \\
-.131 \\
-- \\
--\end{array}$ \\
\hline $\begin{array}{l}8 \\
8 \\
8 \\
8 \\
8\end{array}$ & $\begin{array}{l}43 \\
43 \\
43 \\
43 \\
44\end{array}$ & $\begin{array}{l}30 \\
52 \\
53 \\
57 \\
31\end{array}$ & $\begin{array}{l}-.030 \\
-.100 \\
-- \\
-.070 \\
-.070\end{array}$ & $\begin{array}{l}-.068 \\
-.042 \\
-.016 \\
-.098 \\
--\end{array}$ & $\begin{array}{l}-.068 \\
-.042 \\
-.016 \\
-.098 \\
--\end{array}$ & $\begin{array}{l}-.068 \\
-.042 \\
-.016 \\
-.098 \\
--\end{array}$ & $\begin{array}{l}-.086 \\
-.062 \\
-.024 \\
-.146 \\
--\end{array}$ \\
\hline
\end{tabular}


Appendix B.--Withdrawals simulated at each cell

for all simulations--Continued

\begin{tabular}{|c|c|c|c|c|c|c|c|}
\hline $\begin{array}{l}\text { Model } \\
\text { layer }\end{array}$ & $\begin{array}{c}\text { Cell } \\
\text { column }\end{array}$ & $\begin{array}{l}\text { Cell } \\
\text { row }\end{array}$ & $\begin{array}{l}\text { Calibration } \\
\text { simulation } \\
(1970-79)\end{array}$ & $\begin{array}{c}\text { Scenario } \\
1\end{array}$ & $\begin{array}{c}\text { Scenario } \\
2\end{array}$ & $\underset{3}{\text { Scenario }}$ & $\underset{4}{\text { Scenario }}$ \\
\hline $\begin{array}{l}8 \\
8 \\
8 \\
8 \\
8\end{array}$ & $\begin{array}{l}44 \\
44 \\
44 \\
44 \\
45\end{array}$ & $\begin{array}{l}52 \\
53 \\
56 \\
57 \\
25\end{array}$ & $\begin{array}{r}-0.070 \\
-.040 \\
.000 \\
-.020 \\
-1.930\end{array}$ & $\begin{array}{c}-- \\
-\overline{0} \\
-0.098 \\
-\overline{174}\end{array}$ & $\begin{array}{c}-- \\
-- \\
-0.098 \\
-\overline{174} \\
-1.10\end{array}$ & $\begin{array}{c}-- \\
-\overline{-} \\
-0.098 \\
-\overline{174}\end{array}$ & $\begin{array}{c}-- \\
-\overline{-} \\
-0.147 \\
-\overline{-1} \\
-1.480\end{array}$ \\
\hline $\begin{array}{l}8 \\
8 \\
8 \\
8 \\
8\end{array}$ & $\begin{array}{l}45 \\
45 \\
45 \\
45 \\
45\end{array}$ & $\begin{array}{l}26 \\
33 \\
34 \\
52 \\
53\end{array}$ & $\begin{array}{c}-10.210 \\
-- \\
-.010 \\
-.050\end{array}$ & $\begin{array}{c}-6.842 \\
-.913 \\
-.021 \\
-- \\
-.094\end{array}$ & $\begin{array}{r}-6.842 \\
-.913 \\
-.021 \\
-- \\
-.094\end{array}$ & $\begin{array}{c}-6.842 \\
-.913 \\
-.021 \\
-- \\
-.094\end{array}$ & $\begin{array}{c}-8.624 \\
-1.151 \\
-.022 \\
-- \\
-.141\end{array}$ \\
\hline $\begin{array}{l}8 \\
8 \\
8 \\
8 \\
8\end{array}$ & $\begin{array}{l}45 \\
45 \\
45 \\
46 \\
46\end{array}$ & $\begin{array}{l}54 \\
55 \\
56 \\
19 \\
20\end{array}$ & $\begin{array}{l}-.030 \\
-.010 \\
-.100 \\
-.590 \\
-.580\end{array}$ & $\begin{array}{l}-.121 \\
-.077 \\
-.213 \\
-.511 \\
-.647\end{array}$ & $\begin{array}{l}-.121 \\
-.077 \\
-.213 \\
-.511 \\
-.647\end{array}$ & $\begin{array}{l}-.121 \\
-.077 \\
-.213 \\
-.511 \\
-.647\end{array}$ & $\begin{array}{l}-.182 \\
-.115 \\
-.319 \\
-.767 \\
-.816\end{array}$ \\
\hline $\begin{array}{l}8 \\
8 \\
8 \\
8 \\
8\end{array}$ & $\begin{array}{l}46 \\
46 \\
46 \\
46 \\
46\end{array}$ & $\begin{array}{l}25 \\
26 \\
34 \\
35 \\
37\end{array}$ & $\begin{array}{r}-3.500 \\
-.950 \\
-.270 \\
-.440 \\
-.400\end{array}$ & $\begin{array}{c}-3.357 \\
-1.627 \\
-- \\
-.049 \\
-.872\end{array}$ & $\begin{array}{c}-3.357 \\
-1.627 \\
-- \\
-.049 \\
-.872\end{array}$ & $\begin{array}{c}-3.357 \\
-1.627 \\
-- \\
-.049 \\
-.872\end{array}$ & $\begin{array}{r}-4.232 \\
-2.051 \\
-- \\
-.066 \\
-1.176\end{array}$ \\
\hline $\begin{array}{l}8 \\
8 \\
8 \\
8 \\
8\end{array}$ & $\begin{array}{l}46 \\
46 \\
46 \\
47 \\
47\end{array}$ & $\begin{array}{l}51 \\
55 \\
56 \\
14 \\
15\end{array}$ & $\begin{array}{c}-.020 \\
-.030 \\
-.030 \\
-- \\
--\end{array}$ & $\begin{array}{r}-.050 \\
-.086 \\
-.071 \\
-2.002 \\
-1.183\end{array}$ & $\begin{array}{r}-.050 \\
-.086 \\
-.071 \\
-2.032 \\
-1.200\end{array}$ & $\begin{array}{r}-.050 \\
-.086 \\
-.071 \\
-2.002 \\
-1.183\end{array}$ & $\begin{array}{r}-.074 \\
-.129 \\
-.106 \\
-2.730 \\
-1.612\end{array}$ \\
\hline $\begin{array}{l}8 \\
8 \\
8 \\
8 \\
8\end{array}$ & $\begin{array}{l}47 \\
47 \\
47 \\
47 \\
47\end{array}$ & $\begin{array}{l}32 \\
35 \\
38 \\
41 \\
48\end{array}$ & $\begin{array}{r}-2.960 \\
-.090 \\
-.600 \\
-.690 \\
-.010\end{array}$ & $\begin{array}{r}-3.777 \\
-- \\
-.146 \\
-3.186 \\
-.034\end{array}$ & $\begin{array}{r}-3.777 \\
-- \\
-.146 \\
-3.186 \\
-.034\end{array}$ & $\begin{array}{r}-3.777 \\
-. \\
-.146 \\
-3.186 \\
-.034\end{array}$ & $\begin{array}{r}-4.761 \\
-- \\
-.196 \\
-4.295 \\
-.051\end{array}$ \\
\hline $\begin{array}{l}8 \\
8 \\
8 \\
8 \\
8\end{array}$ & $\begin{array}{l}47 \\
47 \\
48 \\
48 \\
48\end{array}$ & $\begin{array}{l}55 \\
56 \\
12 \\
36 \\
37\end{array}$ & $\begin{array}{r}-.030 \\
-.080 \\
-.050 \\
-1.400 \\
-1.320\end{array}$ & $\begin{array}{r}-.055 \\
-.296 \\
-- \\
-2.157 \\
-1.327\end{array}$ & $\begin{array}{r}-.055 \\
-.296 \\
-- \\
-2.157 \\
-1.327\end{array}$ & $\begin{array}{r}-.055 \\
-.296 \\
-- \\
-2.157 \\
-1.327\end{array}$ & $\begin{array}{c}-.083 \\
-.444 \\
-- \\
-2.907 \\
-1.672\end{array}$ \\
\hline $\begin{array}{l}8 \\
8 \\
8 \\
8 \\
8\end{array}$ & $\begin{array}{l}48 \\
48 \\
48 \\
48 \\
48\end{array}$ & $\begin{array}{l}38 \\
39 \\
41 \\
42 \\
46\end{array}$ & $\begin{array}{l}-.910 \\
-.150 \\
-.410 \\
-.410 \\
-.560\end{array}$ & $\begin{array}{c}-1.135 \\
-- \\
-1.184 \\
-1.591 \\
--\end{array}$ & $\begin{array}{c}-1.135 \\
-- \\
-1.184 \\
-1.591 \\
--\end{array}$ & $\begin{array}{c}-1.135 \\
-- \\
-1.184 \\
-1.591 \\
--\end{array}$ & $\begin{array}{c}-1.530 \\
-- \\
-1.596 \\
-2.144 \\
--\end{array}$ \\
\hline $\begin{array}{l}8 \\
8 \\
8 \\
8 \\
8\end{array}$ & $\begin{array}{l}48 \\
48 \\
48 \\
48 \\
48\end{array}$ & $\begin{array}{l}47 \\
50 \\
51 \\
52 \\
55\end{array}$ & $\begin{array}{r}-2.820 \\
-.010 \\
-.020 \\
-.060 \\
-.010\end{array}$ & $\begin{array}{l}-.622 \\
-.033 \\
-.021 \\
-.046 \\
-.024\end{array}$ & $\begin{array}{l}-.622 \\
-.033 \\
-.021 \\
-.046 \\
-.024\end{array}$ & $\begin{array}{l}-.622 \\
-.033 \\
-.021 \\
-.046 \\
-.024\end{array}$ & $\begin{array}{l}-.784 \\
-.049 \\
-.031 \\
-.069 \\
-.036\end{array}$ \\
\hline $\begin{array}{l}8 \\
8 \\
8 \\
8 \\
8\end{array}$ & $\begin{array}{l}48 \\
49 \\
49 \\
49 \\
49\end{array}$ & $\begin{array}{l}57 \\
20 \\
36 \\
38 \\
47\end{array}$ & $\begin{array}{r}-.010 \\
-.120 \\
-2.480 \\
-.460 \\
-1.960\end{array}$ & $\begin{array}{r}-.077 \\
-.282 \\
-.330 \\
-.175 \\
-1.105\end{array}$ & $\begin{array}{r}-.077 \\
-.282 \\
-.330 \\
-.175 \\
-1.105\end{array}$ & $\begin{array}{r}-.077 \\
-.282 \\
-.330 \\
-.175 \\
-1.105\end{array}$ & $\begin{array}{r}-.115 \\
-.424 \\
-.416 \\
-.236 \\
-1.393\end{array}$ \\
\hline $\begin{array}{l}8 \\
8 \\
8 \\
8 \\
8\end{array}$ & $\begin{array}{l}49 \\
49 \\
49 \\
49 \\
49\end{array}$ & $\begin{array}{l}49 \\
52 \\
53 \\
54 \\
56\end{array}$ & $\begin{array}{r}-.030 \\
-.080 \\
.000 \\
-.040 \\
-.030\end{array}$ & $\begin{array}{c}-.016 \\
-.302 \\
-- \\
-.073 \\
-.044\end{array}$ & $\begin{array}{l}-.016 \\
-.302 \\
-- \\
-.073 \\
-.044\end{array}$ & $\begin{array}{l}-.016 \\
-.302 \\
-- \\
-.073 \\
-.044\end{array}$ & $\begin{array}{l}-.024 \\
-.453 \\
-- \\
-.110 \\
-.066\end{array}$ \\
\hline $\begin{array}{l}8 \\
8 \\
8 \\
8 \\
8\end{array}$ & $\begin{array}{l}50 \\
50 \\
50 \\
50 \\
50\end{array}$ & $\begin{array}{l}17 \\
36 \\
48 \\
49 \\
50\end{array}$ & $\begin{array}{l}-.330 \\
-.500 \\
-.060 \\
-.040 \\
-.070\end{array}$ & $\begin{array}{l}-.295 \\
-.257 \\
-.027 \\
-.039 \\
-.148\end{array}$ & $\begin{array}{l}-.295 \\
-.257 \\
-.027 \\
-.039 \\
-.148\end{array}$ & $\begin{array}{l}-.295 \\
-.257 \\
-.027 \\
-.039 \\
-.148\end{array}$ & $\begin{array}{l}-.398 \\
-.324 \\
-.040 \\
-.059 \\
-.222\end{array}$ \\
\hline
\end{tabular}


Appendix B.--Withdrawals simulated at each cell

for all simulations--Continued

\begin{tabular}{|c|c|c|c|c|c|c|c|}
\hline $\begin{array}{l}\text { Model } \\
\text { layer }\end{array}$ & $\begin{array}{l}\text { Cell } \\
\text { column }\end{array}$ & $\begin{array}{l}\text { Cell } \\
\text { row }\end{array}$ & $\begin{array}{l}\text { Calibration } \\
\text { simulation } \\
(1970-79)\end{array}$ & $\underset{1}{\text { Scenario }}$ & $\begin{array}{c}\text { Scenario } \\
2\end{array}$ & $\begin{array}{c}\text { Scenario } \\
3\end{array}$ & $\underset{4}{\text { Scenario }}$ \\
\hline $\begin{array}{l}8 \\
8 \\
8 \\
8 \\
8\end{array}$ & $\begin{array}{l}50 \\
50 \\
50 \\
51 \\
51\end{array}$ & $\begin{array}{r}53 \\
55 \\
56 \\
8 \\
11\end{array}$ & $\begin{array}{r}-0.010 \\
-.010 \\
-.020 \\
-.090 \\
-.390\end{array}$ & $\begin{array}{r}-0.059 \\
-.053 \\
-.075 \\
-.170 \\
---\end{array}$ & $\begin{array}{r}-0.059 \\
-.053 \\
-.075 \\
-2.498 \\
--\end{array}$ & $\begin{array}{r}-0.059 \\
-.053 \\
-.075 \\
-.170 \\
---\end{array}$ & $\begin{array}{r}-0.080 \\
-.112 \\
-3.339 \\
--\end{array}$ \\
\hline $\begin{array}{l}8 \\
8 \\
8 \\
8 \\
8\end{array}$ & $\begin{array}{l}51 \\
51 \\
51 \\
51 \\
51\end{array}$ & $\begin{array}{l}13 \\
15 \\
18 \\
19 \\
28\end{array}$ & $\begin{array}{r}.000 \\
-2.720 \\
-.420 \\
-1.010 \\
-.070\end{array}$ & $\begin{array}{r}-.089 \\
-5.317 \\
-.221 \\
-1.491 \\
---\end{array}$ & $\begin{array}{r}-.126 \\
-7.522 \\
-.221 \\
-1.491 \\
--\end{array}$ & $\begin{array}{r}-.089 \\
-5.317 \\
-.221 \\
-1.491 \\
--\end{array}$ & $\begin{array}{r}-.169 \\
-10.096 \\
-.298 \\
-2.010 \\
--\end{array}$ \\
\hline $\begin{array}{l}8 \\
8 \\
8 \\
8 \\
8\end{array}$ & $\begin{array}{l}51 \\
51 \\
51 \\
51 \\
51\end{array}$ & $\begin{array}{l}38 \\
39 \\
40 \\
44 \\
45\end{array}$ & $\begin{array}{r}-.290 \\
-.170 \\
-3.540 \\
-.640 \\
-4.290\end{array}$ & $\begin{array}{r}-.247 \\
-.319 \\
-2.751 \\
-7.927 \\
---\end{array}$ & $\begin{array}{r}-.277 \\
-.357 \\
-2.751 \\
-7.927 \\
---\end{array}$ & $\begin{array}{r}-.247 \\
-. .319 \\
-2.751 \\
-7.927 \\
---\end{array}$ & $\begin{array}{r}-.365 \\
-. .471 \\
-3.468 \\
-7.927 \\
---\end{array}$ \\
\hline $\begin{array}{l}8 \\
8 \\
8 \\
8 \\
8\end{array}$ & $\begin{array}{l}51 \\
51 \\
51 \\
51 \\
51\end{array}$ & $\begin{array}{l}48 \\
49 \\
50 \\
51 \\
52\end{array}$ & $\begin{array}{l}-.040 \\
-.100 \\
-.030 \\
-.030 \\
-.030\end{array}$ & $\begin{array}{l}-.059 \\
-.264 \\
-.025 \\
-.156 \\
-.069\end{array}$ & $\begin{array}{l}-.059 \\
-.264 \\
-.025 \\
-.156 \\
-.069\end{array}$ & $\begin{array}{l}-.059 \\
-.264 \\
-.025 \\
-.156 \\
-.069\end{array}$ & $\begin{array}{l}-.089 \\
-.395 \\
-.038 \\
-.234 \\
-.103 \\
-\quad 070\end{array}$ \\
\hline $\begin{array}{l}8 \\
8 \\
8 \\
8 \\
8\end{array}$ & $\begin{array}{l}52 \\
52 \\
52 \\
52 \\
52\end{array}$ & $\begin{array}{l}4 \\
11 \\
17 \\
21 \\
22\end{array}$ & $\begin{array}{l}-- \\
-.540 \\
-.010 \\
-.150 \\
-.210\end{array}$ & $\begin{array}{c}-.052 \\
-- \\
-- \\
-- \\
--\end{array}$ & $\begin{array}{c}-.052 \\
-- \\
-- \\
-- \\
--\end{array}$ & $\begin{array}{c}-.052 \\
-- \\
-- \\
-- \\
--\end{array}$ & $\begin{array}{c}-.070 \\
-- \\
-- \\
-- \\
-- \\
-\end{array}$ \\
\hline $\begin{array}{l}8 \\
8 \\
8 \\
8 \\
8\end{array}$ & $\begin{array}{l}52 \\
52 \\
52 \\
52 \\
52\end{array}$ & $\begin{array}{l}30 \\
32 \\
41 \\
42 \\
48\end{array}$ & $\begin{array}{l}-.010 \\
-.050 \\
-.250 \\
-.180 \\
-.070\end{array}$ & $\begin{array}{l}-.002 \\
-.- \\
-.223 \\
-.441 \\
-.182\end{array}$ & $\begin{array}{l}-.003 \\
-- \\
-.223 \\
-.441 \\
-.182\end{array}$ & $\begin{array}{l}-.002 \\
-- \\
-.223 \\
-.441 \\
-.182\end{array}$ & $\begin{array}{r}-. \\
-.300 \\
-.594 \\
-.273 \\
-\quad 120\end{array}$ \\
\hline $\begin{array}{l}8 \\
8 \\
8 \\
8 \\
8\end{array}$ & $\begin{array}{l}52 \\
52 \\
52 \\
52 \\
52\end{array}$ & $\begin{array}{l}49 \\
50 \\
51 \\
52 \\
54\end{array}$ & $\begin{array}{l}-.060 \\
-.020 \\
-.040 \\
-.070 \\
-.040\end{array}$ & $\begin{array}{c}-.080 \\
-.084 \\
-- \\
-.179 \\
--\end{array}$ & $\begin{array}{c}-.080 \\
-.084 \\
-- \\
-.179 \\
--\end{array}$ & $\begin{array}{c}-.080 \\
-.084 \\
-- \\
-.179 \\
--\end{array}$ & $\begin{array}{l}-.120 \\
-.127 \\
-- \\
-.269 \\
--\end{array}$ \\
\hline $\begin{array}{l}8 \\
8 \\
8 \\
8 \\
8\end{array}$ & $\begin{array}{l}52 \\
52 \\
53 \\
53 \\
53\end{array}$ & $\begin{array}{l}55 \\
56 \\
19 \\
26 \\
27\end{array}$ & $\begin{array}{l}-.030 \\
-.250 \\
-.300 \\
-.300 \\
-.300\end{array}$ & $\begin{array}{r}-.038 \\
-. .311 \\
-.017 \\
-.785 \\
-1.971\end{array}$ & $\begin{array}{r}-.038 \\
-.311 \\
-.029 \\
-.785 \\
-3.473\end{array}$ & $\begin{array}{r}-.038 \\
-. .311 \\
-.017 \\
-.785 \\
-1.971\end{array}$ & $\begin{array}{r}-.057 \\
-. .467 \\
-.039 \\
-1.058 \\
-4.593\end{array}$ \\
\hline $\begin{array}{l}8 \\
8 \\
8 \\
8 \\
8\end{array}$ & $\begin{array}{l}53 \\
53 \\
53 \\
53 \\
53\end{array}$ & $\begin{array}{l}28 \\
42 \\
43 \\
44 \\
48\end{array}$ & $\begin{array}{l}-.080 \\
-.340 \\
-.340 \\
-.010 \\
-.020\end{array}$ & $\begin{array}{c}-- \\
-1.017 \\
-.433 \\
-.064 \\
--\end{array}$ & $\begin{array}{c}-- \\
-1.354 \\
-.577 \\
-.064 \\
---\end{array}$ & $\begin{array}{c}-- \\
-1.017 \\
-.433 \\
-.064 \\
--\end{array}$ & $\begin{array}{c}-1.811 \\
-.772 \\
-.096 \\
-- \\
--\end{array}$ \\
\hline $\begin{array}{l}8 \\
8 \\
8 \\
8 \\
8\end{array}$ & $\begin{array}{l}53 \\
53 \\
53 \\
53 \\
53\end{array}$ & $\begin{array}{l}49 \\
50 \\
51 \\
52 \\
53\end{array}$ & $\begin{array}{l}-.080 \\
-.050 \\
-.050 \\
-.130 \\
-.010\end{array}$ & $\begin{array}{r}-- \\
-.147 \\
-.177 \\
-.184 \\
-.038\end{array}$ & $\begin{array}{r}-- \\
-.147 \\
-.177 \\
-.184 \\
-.038\end{array}$ & $\begin{array}{r}-- \\
-.147 \\
-.177 \\
-.184 \\
-.038\end{array}$ & $\begin{array}{l}-.220 \\
-.265 \\
-.276 \\
-.057 \\
-.\end{array}$ \\
\hline $\begin{array}{l}8 \\
8 \\
8 \\
8 \\
8\end{array}$ & $\begin{array}{l}53 \\
53 \\
53 \\
54 \\
54\end{array}$ & $\begin{array}{l}54 \\
55 \\
56 \\
12 \\
13\end{array}$ & $\begin{array}{l}-.020 \\
-.030 \\
-.130 \\
-.190 \\
-.320\end{array}$ & $\begin{array}{r}-- \\
-.079 \\
-.164 \\
-.133 \\
-.371\end{array}$ & $\begin{array}{r}-- \\
-.079 \\
-.164 \\
-.133 \\
-.371\end{array}$ & $\begin{array}{l}-- \\
-.079 \\
-.164 \\
-.133 \\
-.371\end{array}$ & $\begin{array}{r}-.119 \\
-.246 \\
-.179 \\
-.500\end{array}$ \\
\hline $\begin{array}{l}8 \\
8 \\
8 \\
8 \\
8\end{array}$ & $\begin{array}{l}54 \\
54 \\
54 \\
54 \\
54\end{array}$ & $\begin{array}{l}24 \\
29 \\
37 \\
44 \\
49\end{array}$ & $\begin{array}{c}-- \\
-\overline{-} \\
-.010 \\
-- \\
-.010\end{array}$ & $\begin{array}{r}-1.690 \\
-.029 \\
-.025 \\
-.004 \\
-1.842\end{array}$ & $\begin{array}{r}-2.078 \\
-.029 \\
-.025 \\
-.004 \\
-2.013\end{array}$ & $\begin{array}{r}-1.690 \\
-.029 \\
-.025 \\
-.004 \\
-1.842\end{array}$ & $\begin{array}{r}-3.938 \\
-.044 \\
-.037 \\
-.006 \\
-2.670\end{array}$ \\
\hline
\end{tabular}


Appendix B.--Withdrawals simulated at each cell

for all simulations--Continued

\begin{tabular}{|c|c|c|c|c|c|c|c|}
\hline $\begin{array}{l}\text { Model } \\
\text { layer }\end{array}$ & $\begin{array}{c}\text { Cell } \\
\text { column }\end{array}$ & $\begin{array}{l}\text { Cell } \\
\text { row }\end{array}$ & $\begin{array}{l}\text { Calibration } \\
\text { simulation } \\
(1970-79)\end{array}$ & $\underset{1}{\text { Sconario }}$ & $\underset{2}{\text { Sconario }}$ & $\underset{3}{\text { Scenario }}$ & $\underset{4}{\text { Scenario }}$ \\
\hline $\begin{array}{l}8 \\
8 \\
8 \\
8 \\
8\end{array}$ & $\begin{array}{l}54 \\
54 \\
54 \\
54 \\
54\end{array}$ & $\begin{array}{l}50 \\
51 \\
52 \\
53 \\
54\end{array}$ & $\begin{array}{r}-0.040 \\
-.030 \\
-.090 \\
-.090 \\
-.040\end{array}$ & $\begin{array}{c}-0.130 \\
-.098 \\
-.129 \\
-.059 \\
--\end{array}$ & $\begin{array}{c}-0.130 \\
-.098 \\
-.129 \\
-.059 \\
--\end{array}$ & $\begin{array}{c}-0.130 \\
-.098 \\
-.129 \\
-.059 \\
--\end{array}$ & $\begin{array}{c}-0.195 \\
-.147 \\
-.194 \\
-.089 \\
---\end{array}$ \\
\hline $\begin{array}{l}8 \\
8 \\
8 \\
8 \\
8\end{array}$ & $\begin{array}{l}54 \\
55 \\
55 \\
55 \\
55\end{array}$ & $\begin{array}{l}56 \\
33 \\
42 \\
44 \\
45\end{array}$ & $\begin{array}{r}-.140 \\
-1.080 \\
-1.550 \\
.000 \\
-.070\end{array}$ & $\begin{array}{r}-.160 \\
-9.355 \\
-6.489 \\
-.007 \\
-.036\end{array}$ & $\begin{array}{r}-.160 \\
-15.050 \\
-8.645 \\
-.007 \\
-.036\end{array}$ & $\begin{array}{r}-.160 \\
-9.355 \\
-6.489 \\
-.007 \\
-.036\end{array}$ & $\begin{array}{r}-.241 \\
-19.923 \\
-11.560 \\
-.011 \\
-.053\end{array}$ \\
\hline $\begin{array}{l}8 \\
8 \\
8 \\
8 \\
8\end{array}$ & $\begin{array}{l}55 \\
55 \\
55 \\
55 \\
55\end{array}$ & $\begin{array}{l}48 \\
49 \\
50 \\
51 \\
52\end{array}$ & $\begin{array}{l}-.040 \\
-.110 \\
-.100 \\
-.150 \\
-.110\end{array}$ & $\begin{array}{l}-.667 \\
-.141 \\
-.247 \\
-.183 \\
-.147\end{array}$ & $\begin{array}{l}-.667 \\
-.141 \\
-.247 \\
-.183 \\
-.147\end{array}$ & $\begin{array}{l}-.667 \\
-.141 \\
-.247 \\
-.183 \\
-.147\end{array}$ & $\begin{array}{r}-1.000 \\
-.212 \\
-.371 \\
-.274 \\
-.221\end{array}$ \\
\hline $\begin{array}{l}8 \\
8 \\
8 \\
8 \\
8\end{array}$ & $\begin{array}{l}55 \\
55 \\
55 \\
55 \\
56\end{array}$ & $\begin{array}{l}53 \\
54 \\
55 \\
56 \\
11\end{array}$ & $\begin{array}{l}-.030 \\
-.020 \\
-.080 \\
-.010 \\
-.070\end{array}$ & $\begin{array}{l}-- \\
-.014 \\
-.076 \\
-.038 \\
-.022\end{array}$ & $\begin{array}{l}-- \\
-.014 \\
-.076 \\
-.038 \\
-.022\end{array}$ & $\begin{array}{l}--. \\
-.014 \\
-.076 \\
-.038 \\
-.022\end{array}$ & $\begin{array}{l}-- \\
-.019 \\
-.114 \\
-.057 \\
-.033\end{array}$ \\
\hline $\begin{array}{l}8 \\
8 \\
8 \\
8 \\
8\end{array}$ & $\begin{array}{l}56 \\
56 \\
56 \\
56 \\
56\end{array}$ & $\begin{array}{l}27 \\
45 \\
47 \\
49 \\
50\end{array}$ & $\begin{array}{r}-.230 \\
-10.670 \\
-.050 \\
-.080 \\
-.260\end{array}$ & $\begin{array}{r}-.249 \\
-10.790 \\
-.046 \\
-.202 \\
-.287\end{array}$ & $\begin{array}{r}-.249 \\
-10.790 \\
-.046 \\
-.202 \\
-.287\end{array}$ & $\begin{array}{r}-.249 \\
-10.790 \\
-.046 \\
-.202 \\
-.287\end{array}$ & $\begin{array}{r}-.335 \\
-13.601 \\
-.069 \\
-.304 \\
-.430\end{array}$ \\
\hline $\begin{array}{l}8 \\
8 \\
8 \\
8 \\
8\end{array}$ & $\begin{array}{l}56 \\
56 \\
56 \\
56 \\
56\end{array}$ & $\begin{array}{l}51 \\
52 \\
53 \\
54 \\
55\end{array}$ & $\begin{array}{l}-.140 \\
-.230 \\
-.080 \\
-.040 \\
-.050\end{array}$ & $\begin{array}{l}-.316 \\
-.315 \\
-.111 \\
-.100 \\
-.112\end{array}$ & $\begin{array}{l}-.316 \\
-.315 \\
-.111 \\
-.100 \\
-.112\end{array}$ & $\begin{array}{l}-.316 \\
-.315 \\
-.111 \\
-.100 \\
-.112\end{array}$ & $\begin{array}{l}-.474 \\
-.473 \\
-.167 \\
-.150 \\
-.167\end{array}$ \\
\hline $\begin{array}{l}8 \\
8 \\
8 \\
8 \\
8\end{array}$ & $\begin{array}{l}56 \\
57 \\
57 \\
57 \\
57\end{array}$ & $\begin{array}{r}56 \\
5 \\
17 \\
36 \\
39\end{array}$ & $\begin{array}{r}-. \\
-.030 \\
-- \\
-.030 \\
-4.870\end{array}$ & $\begin{array}{r}-.034 \\
-.007 \\
-.036 \\
-.022 \\
-6.052\end{array}$ & $\begin{array}{r}-.034 \\
-.007 \\
-.036 \\
-.022 \\
-6.052\end{array}$ & $\begin{array}{r}-.034 \\
-.007 \\
-.036 \\
-.022 \\
-6.052\end{array}$ & $\begin{array}{r}-.051 \\
-.011 \\
-.039 \\
-.033 \\
-7.628\end{array}$ \\
\hline $\begin{array}{l}8 \\
8 \\
8 \\
8 \\
8\end{array}$ & $\begin{array}{l}57 \\
57 \\
57 \\
57 \\
57\end{array}$ & $\begin{array}{l}40 \\
41 \\
42 \\
45 \\
49\end{array}$ & $\begin{array}{l}-.010 \\
-.010 \\
-.030 \\
-- \\
-.160\end{array}$ & $\begin{array}{c}-- \\
-- \\
-.031 \\
-.0360\end{array}$ & $\begin{array}{c}-- \\
-- \\
-\overline{-} \\
-.031 \\
-.160\end{array}$ & $\begin{array}{c}-- \\
-- \\
-- \\
-.031 \\
-.160\end{array}$ & $\begin{array}{c}-- \\
-- \\
-.046 \\
-.240\end{array}$ \\
\hline $\begin{array}{l}8 \\
8 \\
8 \\
8 \\
8\end{array}$ & $\begin{array}{l}57 \\
57 \\
57 \\
57 \\
57\end{array}$ & $\begin{array}{l}50 \\
51 \\
52 \\
54 \\
55\end{array}$ & $\begin{array}{l}-.230 \\
-.140 \\
-.260 \\
-.010 \\
-.100\end{array}$ & $\begin{array}{l}-.265 \\
-.272 \\
-.586 \\
-.025 \\
-.533\end{array}$ & $\begin{array}{l}-.265 \\
-.272 \\
-.586 \\
-.025 \\
-.533\end{array}$ & $\begin{array}{l}-.265 \\
-.272 \\
-.586 \\
-.025 \\
-.533\end{array}$ & $\begin{array}{l}-.397 \\
-.408 \\
-.879 \\
-.037 \\
-.799\end{array}$ \\
\hline $\begin{array}{l}8 \\
8 \\
8 \\
8 \\
8\end{array}$ & $\begin{array}{l}57 \\
58 \\
58 \\
58 \\
58\end{array}$ & $\begin{array}{l}56 \\
24 \\
38 \\
45 \\
48\end{array}$ & $\begin{array}{r}-. \\
-.220 \\
-.010 \\
-.060 \\
-1.120\end{array}$ & $\begin{array}{r}-.021 \\
-. .101 \\
-.043 \\
-.031 \\
-1.853\end{array}$ & $\begin{array}{r}-.021 \\
-. .101 \\
-.043 \\
-.031 \\
-2.028\end{array}$ & $\begin{array}{r}-.021 \\
-. .101 \\
-.043 \\
-.031 \\
-1.853\end{array}$ & $\begin{array}{r}-.032 \\
-. .152 \\
-.065 \\
-.046 \\
-2.685\end{array}$ \\
\hline $\begin{array}{l}8 \\
8 \\
8 \\
8 \\
8\end{array}$ & $\begin{array}{l}58 \\
58 \\
58 \\
58 \\
58\end{array}$ & $\begin{array}{l}49 \\
50 \\
51 \\
52 \\
53\end{array}$ & $\begin{array}{l}-.670 \\
-.030 \\
-.250 \\
-.250 \\
-.070\end{array}$ & $\begin{array}{r}-1.121 \\
-. \\
-.520 \\
-.517 \\
-.059\end{array}$ & $\begin{array}{r}-1.218 \\
-- \\
-.520 \\
-.517 \\
-.059\end{array}$ & $\begin{array}{r}-1.121 \\
-. \\
-.520 \\
-.517 \\
-.059\end{array}$ & $\begin{array}{r}-1.629 \\
-- \\
-.780 \\
-.776 \\
-.088\end{array}$ \\
\hline $\begin{array}{l}8 \\
8 \\
8 \\
8 \\
8\end{array}$ & $\begin{array}{l}58 \\
59 \\
59 \\
59 \\
59\end{array}$ & $\begin{array}{r}55 \\
9 \\
15 \\
41 \\
44\end{array}$ & $\begin{array}{l}-.080 \\
-.040 \\
-.100 \\
-.040 \\
-.010\end{array}$ & $\begin{array}{l}-.295 \\
-.012 \\
-.391 \\
-.010 \\
--\end{array}$ & $\begin{array}{c}-.295 \\
-.012 \\
-.425 \\
-.010 \\
--\end{array}$ & $\begin{array}{l}-.295 \\
-.012 \\
-.391 \\
-.010 \\
-.\end{array}$ & $\begin{array}{l}-.442 \\
-.018 \\
-.560 \\
-.015 \\
--.\end{array}$ \\
\hline
\end{tabular}


Appendix B.--Withdrawals simulated at each cell

for all simulations--Continued

\begin{tabular}{|c|c|c|c|c|c|c|c|}
\hline $\begin{array}{l}\text { Model } \\
\text { layer }\end{array}$ & $\begin{array}{c}\text { Cell } \\
\text { column }\end{array}$ & $\begin{array}{l}\text { Cell } \\
\text { row }\end{array}$ & $\begin{array}{l}\text { Calibration } \\
\text { simulation } \\
\text { (1970-79) }\end{array}$ & $\underset{1}{\text { Scenario }}$ & $\underset{2}{\text { Scenario }}$ & $\underset{3}{\text { Scenario }}$ & Scenario \\
\hline $\begin{array}{l}8 \\
8 \\
8 \\
8 \\
8\end{array}$ & $\begin{array}{l}59 \\
59 \\
59 \\
59 \\
59\end{array}$ & $\begin{array}{l}45 \\
46 \\
48 \\
49 \\
50\end{array}$ & $\begin{array}{r}-0.010 \\
-.010 \\
-.150 \\
-.720 \\
-.170\end{array}$ & $\begin{array}{c}-- \\
-- \\
-0.163 \\
-.080 \\
-.493\end{array}$ & $\begin{array}{c}-- \\
-- \\
-0.178 \\
-.080 \\
-.493\end{array}$ & $\begin{array}{c}-- \\
-\overline{-} \\
-0.163 \\
-.080 \\
-.493\end{array}$ & $\begin{array}{r}-- \\
-- \\
-0.236 \\
-.101 \\
-.740\end{array}$ \\
\hline $\begin{array}{l}8 \\
8 \\
8 \\
8 \\
8\end{array}$ & $\begin{array}{l}59 \\
59 \\
59 \\
59 \\
59\end{array}$ & $\begin{array}{l}51 \\
52 \\
53 \\
54 \\
55\end{array}$ & $\begin{array}{l}-.070 \\
-.060 \\
-.050 \\
-.050 \\
-.060\end{array}$ & $\begin{array}{l}-.244 \\
-.131 \\
-.057 \\
-.032 \\
-.205\end{array}$ & $\begin{array}{l}-.244 \\
-.131 \\
-.057 \\
-.032 \\
-.205\end{array}$ & $\begin{array}{l}-.244 \\
-.131 \\
-.057 \\
-.032 \\
-.205\end{array}$ & $\begin{array}{l}-.365 \\
-.197 \\
-.086 \\
-.048 \\
-.308\end{array}$ \\
\hline $\begin{array}{l}8 \\
8 \\
8 \\
8 \\
8\end{array}$ & $\begin{array}{l}59 \\
60 \\
60 \\
60 \\
60\end{array}$ & $\begin{array}{l}56 \\
12 \\
13 \\
14 \\
15\end{array}$ & $\begin{array}{r}.000 \\
-- \\
-.100 \\
-.760 \\
-.020\end{array}$ & $\begin{array}{l}-.101 \\
-.047 \\
-.001 \\
-.531 \\
-.377\end{array}$ & $\begin{array}{l}-.101 \\
-.047 \\
-.002 \\
-.578 \\
-.410\end{array}$ & $\begin{array}{l}-.101 \\
-.047 \\
-.001 \\
-.531 \\
-.377\end{array}$ & $\begin{array}{l}-.152 \\
-.071 \\
-.002 \\
-.762 \\
-.540\end{array}$ \\
\hline $\begin{array}{l}8 \\
8 \\
8 \\
8 \\
8\end{array}$ & $\begin{array}{l}60 \\
60 \\
60 \\
60 \\
60\end{array}$ & $\begin{array}{l}16 \\
49 \\
50 \\
52 \\
53\end{array}$ & $\begin{array}{l}-.260 \\
-.050 \\
-.020 \\
-.010 \\
-.010\end{array}$ & $\begin{array}{l}-.513 \\
-.081 \\
-.062 \\
-.050\end{array}$ & $\begin{array}{l}-.900 \\
-.081 \\
-.062 \\
-.050\end{array}$ & $\begin{array}{c}-.513 \\
-- \\
-.081 \\
-.062 \\
-.050\end{array}$ & $\begin{array}{c}-1.108 \\
-.121 \\
-.092 \\
-.075\end{array}$ \\
\hline $\begin{array}{l}8 \\
8 \\
8 \\
8 \\
8\end{array}$ & $\begin{array}{l}60 \\
61 \\
61 \\
61 \\
61\end{array}$ & $\begin{array}{l}54 \\
14 \\
15 \\
51 \\
52\end{array}$ & $\begin{array}{l}-.120 \\
-.760 \\
-.360 \\
-.050 \\
-.010\end{array}$ & $\begin{array}{l}-.612 \\
-.324 \\
-.886 \\
-.204 \\
-.021\end{array}$ & $\begin{array}{l}-.612 \\
-.352 \\
-.963 \\
-.204 \\
-.021\end{array}$ & $\begin{array}{l}-.612 \\
-.324 \\
-.886 \\
-.204 \\
-.021\end{array}$ & $\begin{array}{r}-.918 \\
-.464 \\
-1.270 \\
-.306 \\
-.032\end{array}$ \\
\hline $\begin{array}{l}8 \\
8 \\
8 \\
8 \\
8\end{array}$ & $\begin{array}{l}61 \\
61 \\
62 \\
62 \\
62\end{array}$ & $\begin{array}{l}53 \\
54 \\
28 \\
50 \\
51\end{array}$ & $\begin{array}{l}-.050 \\
-.010 \\
-.300 \\
-.070 \\
-.060\end{array}$ & $\begin{array}{l}-.154 \\
-.052 \\
-- \\
-.142 \\
-.242\end{array}$ & $\begin{array}{l}-.154 \\
-.052 \\
--.142 \\
-.1242\end{array}$ & $\begin{array}{l}-.154 \\
-.052 \\
--.142 \\
-.1242\end{array}$ & $\begin{array}{l}-.232 \\
-.078 \\
-- \\
-.213 \\
-.363\end{array}$ \\
\hline $\begin{array}{l}8 \\
8 \\
8 \\
8 \\
8\end{array}$ & $\begin{array}{l}62 \\
62 \\
63 \\
63 \\
64\end{array}$ & $\begin{array}{l}53 \\
54 \\
50 \\
54 \\
27\end{array}$ & $\begin{array}{l}-.040 \\
-.020 \\
-.050 \\
-.010 \\
-.660\end{array}$ & $\begin{array}{l}-.124 \\
-.075 \\
-.356 \\
-.042 \\
-.600\end{array}$ & $\begin{array}{l}-.124 \\
-.075 \\
-.356 \\
-.042 \\
-.600\end{array}$ & $\begin{array}{l}-.124 \\
-.075 \\
-.356 \\
-.042 \\
-.600\end{array}$ & $\begin{array}{l}-.186 \\
-.112 \\
-.535 \\
-.062 \\
-.756\end{array}$ \\
\hline $\begin{array}{l}8 \\
8 \\
8 \\
8 \\
9\end{array}$ & $\begin{array}{r}64 \\
64 \\
65 \\
66 \\
7\end{array}$ & $\begin{array}{l}50 \\
52 \\
50 \\
50 \\
47\end{array}$ & $\begin{array}{l}-.040 \\
-.030 \\
-.010 \\
-.010 \\
.000\end{array}$ & $\begin{array}{l}-.137 \\
-.091 \\
-.006 \\
-.032 \\
--\end{array}$ & $\begin{array}{l}-.137 \\
-.091 \\
-.006 \\
-.032 \\
--\end{array}$ & $\begin{array}{c}-.137 \\
-.091 \\
-.006 \\
-.032 \\
---\end{array}$ & $\begin{array}{l}-.206 \\
-.136 \\
-.009 \\
-.048 \\
--\end{array}$ \\
\hline $\begin{array}{l}9 \\
9 \\
9 \\
9 \\
9\end{array}$ & $\begin{array}{r}8 \\
8 \\
8 \\
8 \\
13\end{array}$ & $\begin{array}{l}18 \\
20 \\
42 \\
44 \\
10\end{array}$ & $\begin{array}{l}-.030 \\
-. \\
-.100 \\
-.270 \\
-.160\end{array}$ & $\begin{array}{c}-.110 \\
-.061 \\
-.059 \\
-- \\
--\end{array}$ & $\begin{array}{c}-.219 \\
-.095 \\
-.059 \\
-- \\
--\end{array}$ & $\begin{array}{c}-.110 \\
-.061 \\
-.059 \\
-- \\
--\end{array}$ & $\begin{array}{c}-.258 \\
-.118 \\
-.088 \\
-- \\
--\end{array}$ \\
\hline $\begin{array}{l}9 \\
9 \\
9 \\
9 \\
9\end{array}$ & $\begin{array}{l}13 \\
14 \\
15 \\
15 \\
15\end{array}$ & $\begin{array}{r}49 \\
10 \\
9 \\
10 \\
33\end{array}$ & $\begin{array}{l}-.100 \\
-.450 \\
-.080 \\
-.880 \\
-.030\end{array}$ & $\begin{array}{r}-.020 \\
-5.548 \\
-.038 \\
- \\
--\end{array}$ & $\begin{array}{r}-.042 \\
-7.087 \\
-.038 \\
-- \\
--\end{array}$ & $\begin{array}{r}-.020 \\
-4.774 \\
-.038 \\
-- \\
--\end{array}$ & $\begin{array}{r}-.059 \\
-9.944 \\
-.057 \\
-- \\
--\end{array}$ \\
\hline $\begin{array}{l}9 \\
9 \\
9 \\
9 \\
9\end{array}$ & $\begin{array}{l}16 \\
17 \\
17 \\
17 \\
17\end{array}$ & $\begin{array}{r}28 \\
9 \\
16 \\
22 \\
34\end{array}$ & $\begin{array}{l}-.230 \\
-.110 \\
-.230 \\
-.080 \\
-.090\end{array}$ & $\begin{array}{l}-.083 \\
-- \\
-.155 \\
--.328 \\
-.328\end{array}$ & $\begin{array}{c}-.144 \\
-\overline{-} \\
-.156 \\
-.077 \\
-.37\end{array}$ & $\begin{array}{c}-.083 \\
-- \\
-.155 \\
-.- \\
-.328\end{array}$ & $\begin{array}{r}-.930 \\
-.012 \\
-.012 \\
-.470\end{array}$ \\
\hline $\begin{array}{l}9 \\
9 \\
9 \\
9 \\
9\end{array}$ & $\begin{array}{l}18 \\
22 \\
22 \\
22 \\
24\end{array}$ & $\begin{array}{r}9 \\
14 \\
22 \\
24 \\
11\end{array}$ & $\begin{array}{l}-.070 \\
-- \\
-.250 \\
-.010 \\
-.680\end{array}$ & $\begin{array}{c}-- \\
-15.500 \\
- \\
-1.650\end{array}$ & $\begin{array}{c}-30.999 \\
- \\
-2.059\end{array}$ & $\begin{array}{c}-- \\
-15.500 \\
- \\
-- \\
-1.650\end{array}$ & $\begin{array}{c}-- \\
-44.527 \\
-- \\
-- \\
-2.769\end{array}$ \\
\hline
\end{tabular}


Appendix B.--Withdrawals simulated at each cell

for all simulations--Continued

\begin{tabular}{|c|c|c|c|c|c|c|c|}
\hline $\begin{array}{l}\text { Model } \\
\text { layer }\end{array}$ & $\begin{array}{c}\text { Cell } \\
\text { column }\end{array}$ & $\begin{array}{l}\text { Cell } \\
\text { row }\end{array}$ & $\begin{array}{l}\text { Calibration } \\
\text { simulation } \\
(1970-79)\end{array}$ & $\begin{array}{c}\text { Scenario } \\
1\end{array}$ & $\begin{array}{c}\text { Scenario } \\
2\end{array}$ & $\begin{array}{c}\text { Scenario } \\
3\end{array}$ & $\underset{4}{\text { Scenario }}$ \\
\hline $\begin{array}{l}9 \\
9 \\
9 \\
9 \\
9\end{array}$ & $\begin{array}{l}24 \\
26 \\
27 \\
28 \\
28\end{array}$ & $\begin{array}{l}24 \\
10 \\
25 \\
10 \\
30\end{array}$ & $\begin{array}{r}-0.150 \\
-.050 \\
-.010 \\
-.090 \\
.000\end{array}$ & $\begin{array}{l}-- \\
-- \\
-- \\
--\end{array}$ & $\begin{array}{l}-- \\
-- \\
-- \\
--\end{array}$ & $\begin{array}{l}-- \\
-- \\
-- \\
--\end{array}$ & $\begin{array}{l}-- \\
-- \\
-- \\
--\end{array}$ \\
\hline $\begin{array}{l}9 \\
9 \\
9 \\
9 \\
9\end{array}$ & $\begin{array}{l}30 \\
32 \\
33 \\
34 \\
34\end{array}$ & $\begin{array}{r}19 \\
50 \\
27 \\
9 \\
32\end{array}$ & $\begin{array}{l}-.030 \\
-- \\
-.080 \\
-.170 \\
-.070\end{array}$ & $\begin{array}{c}-- \\
-0.005 \\
-- \\
-- \\
--\end{array}$ & $\begin{array}{c}-- \\
-0.005 \\
-- \\
--\end{array}$ & $\begin{array}{c}-- \\
-0.005 \\
-- \\
--\end{array}$ & $\begin{array}{c}-- \\
-0.008 \\
-- \\
-- \\
--\end{array}$ \\
\hline $\begin{array}{l}9 \\
9 \\
9 \\
9 \\
9\end{array}$ & $\begin{array}{l}35 \\
36 \\
36 \\
36 \\
36\end{array}$ & $\begin{array}{r}50 \\
8 \\
15 \\
27 \\
46\end{array}$ & $\begin{array}{r}-.030 \\
-.070 \\
.000 \\
.000 \\
-.020\end{array}$ & $\begin{array}{c}-- \\
-1.117 \\
-- \\
-\overline{015}\end{array}$ & $\begin{array}{c}-- \\
-1.451 \\
-- \\
-. \overline{015}\end{array}$ & $\begin{array}{c}-\overline{1} \\
-1.117 \\
-- \\
-.015\end{array}$ & $\begin{array}{c}-- \\
-2.031 \\
-- \\
-\overline{0} \\
-.023\end{array}$ \\
\hline $\begin{array}{l}9 \\
9 \\
9 \\
9 \\
9\end{array}$ & $\begin{array}{l}36 \\
37 \\
39 \\
42 \\
42\end{array}$ & $\begin{array}{l}51 \\
51 \\
48 \\
28 \\
29\end{array}$ & $\begin{array}{l}-.060 \\
-.020 \\
-.010 \\
-.020 \\
-.020\end{array}$ & $\begin{array}{c}-.008 \\
-.016 \\
-- \\
-- \\
--\end{array}$ & $\begin{array}{c}-.008 \\
-.016 \\
--- \\
--\end{array}$ & $\begin{array}{c}-.008 \\
-.016 \\
-- \\
--\end{array}$ & $\begin{array}{c}-.012 \\
-.024 \\
-- \\
-- \\
--\end{array}$ \\
\hline $\begin{array}{l}9 \\
9 \\
9 \\
9 \\
9\end{array}$ & $\begin{array}{l}43 \\
46 \\
49 \\
49 \\
49\end{array}$ & $\begin{array}{r}25 \\
51 \\
8 \\
20 \\
36\end{array}$ & $\begin{array}{r}.000 \\
-.010 \\
-.010 \\
-.060 \\
-.180\end{array}$ & $\begin{array}{l}-- \\
-.018 \\
-.030 \\
-.050 \\
--\end{array}$ & $\begin{array}{r}-- \\
-.018 \\
-.030 \\
-.050 \\
--\end{array}$ & $\begin{array}{r}-.- \\
-.018 \\
-.030 \\
-.050 \\
--\end{array}$ & $\begin{array}{l}-- \\
-.027 \\
-.045 \\
-.075 \\
--\end{array}$ \\
\hline $\begin{array}{l}9 \\
9 \\
9 \\
9 \\
9\end{array}$ & $\begin{array}{l}49 \\
52 \\
52 \\
53 \\
54\end{array}$ & $\begin{array}{l}37 \\
17 \\
56 \\
55 \\
56\end{array}$ & $\begin{array}{l}-.020 \\
-.010 \\
-.070 \\
-.020 \\
-.140\end{array}$ & $\begin{array}{c}-- \\
-- \\
-.031 \\
-.051 \\
-.197\end{array}$ & $\begin{array}{r}-- \\
-- \\
-.031 \\
-.051 \\
-.197\end{array}$ & $\begin{array}{c}-- \\
-- \\
-.031 \\
-.051 \\
-.197\end{array}$ & $\begin{array}{r}-- \\
-- \\
-.047 \\
-.076 \\
-.295\end{array}$ \\
\hline $\begin{array}{r}9 \\
9 \\
9 \\
9 \\
10\end{array}$ & $\begin{array}{r}55 \\
55 \\
56 \\
56 \\
8\end{array}$ & $\begin{array}{l}55 \\
56 \\
55 \\
56 \\
36\end{array}$ & $\begin{array}{r}-- \\
-.050 \\
-.010 \\
-.050 \\
-.040\end{array}$ & $\begin{array}{l}-.031 \\
-.104 \\
-.059 \\
-.057 \\
--\end{array}$ & $\begin{array}{l}-.031 \\
-.104 \\
-.059 \\
-.057 \\
--\end{array}$ & $\begin{array}{l}-.031 \\
-.104 \\
-.059 \\
-.057 \\
--\end{array}$ & $\begin{array}{l}-.046 \\
-.156 \\
-.088 \\
-.086 \\
--\end{array}$ \\
\hline $\begin{array}{l}10 \\
10 \\
10 \\
10 \\
10\end{array}$ & $\begin{array}{r}9 \\
10 \\
10 \\
15 \\
16\end{array}$ & $\begin{array}{l}15 \\
15 \\
24 \\
33 \\
24\end{array}$ & $\begin{array}{l}-.040 \\
-.100 \\
-.660 \\
-.070 \\
-.270\end{array}$ & $\begin{array}{l}-.078 \\
--. \\
-.997 \\
-.065 \\
-.280\end{array}$ & $\begin{array}{r}-.121 \\
-- \\
-1.052 \\
-.065 \\
-.280\end{array}$ & $\begin{array}{l}-.078 \\
-- \\
-.997 \\
-.065 \\
-.280\end{array}$ & $\begin{array}{r}-.152 \\
-- \\
-1.488 \\
-.097 \\
-.298\end{array}$ \\
\hline $\begin{array}{l}10 \\
10 \\
10 \\
10 \\
10\end{array}$ & $\begin{array}{l}18 \\
23 \\
24 \\
25 \\
27\end{array}$ & $\begin{array}{l}38 \\
13 \\
21 \\
12 \\
21\end{array}$ & $\begin{array}{r}-.440 \\
-- \\
-.920 \\
-1.220 \\
-.390\end{array}$ & $\begin{array}{r}-.150 \\
-.043 \\
-.738 \\
-2.097 \\
--\end{array}$ & $\begin{array}{r}-.150 \\
-.043 \\
-.738 \\
-2.605 \\
--\end{array}$ & $\begin{array}{r}-.150 \\
-.043 \\
-.738 \\
-2.097 \\
--\end{array}$ & $\begin{array}{r}-.160 \\
-.054 \\
-.931 \\
-3.511 \\
--\end{array}$ \\
\hline $\begin{array}{l}10 \\
10 \\
10 \\
10 \\
10\end{array}$ & $\begin{array}{l}27 \\
34 \\
35 \\
36 \\
38\end{array}$ & $\begin{array}{l}49 \\
53 \\
53 \\
53 \\
12\end{array}$ & $\begin{array}{l}-.520 \\
-.030 \\
-.020 \\
-.070 \\
-.230\end{array}$ & $\begin{array}{c}-- \\
-.017 \\
-- \\
-.086 \\
-.568\end{array}$ & $\begin{array}{c}-.- \\
-.017 \\
-- \\
-.086 \\
-.568\end{array}$ & $\begin{array}{c}-- \\
-.017 \\
-.086 \\
-.0868\end{array}$ & $\begin{array}{l}-- \\
-.025 \\
-\overline{-} \\
-.129 \\
-.816\end{array}$ \\
\hline $\begin{array}{l}10 \\
10\end{array}$ & $\begin{array}{l}41 \\
45\end{array}$ & $\begin{array}{l}52 \\
52\end{array}$ & $\begin{array}{l}-.010 \\
-.010\end{array}$ &.$- \overline{-}$ & $-\overline{-0}$ & $-\overline{024}$ &.$- \overline{-0}$ \\
\hline
\end{tabular}


Appendix C.--True differences between model-calculated and observed heads (residuals) for model calibration

\begin{tabular}{|c|c|c|c|c|c|c|c|}
\hline \multirow{2}{*}{$\begin{array}{l}\text { Percent } \\
\text { displacement } \\
\text { from center } \\
\text { to edge of } \\
\text { cell in y- } \\
\text { direction }\end{array}$} & \multirow{2}{*}{$\begin{array}{l}\text { Percent } \\
\text { displacement } \\
\text { from conter } \\
\text { to edge of } \\
\text { cell in } x- \\
\text { direction }\end{array}$} & \multicolumn{3}{|c|}{ Cell Location } & \multirow{2}{*}{$\begin{array}{c}\text { Model } \\
\text { calculated } \\
\text { head }\end{array}$} & \multirow{2}{*}{$\begin{array}{l}\text { Median of } \\
\text { measured } \\
\text { heads, } \\
\text { 1971-80 }\end{array}$} & \multirow{2}{*}{$\begin{array}{l}\text { Difference } \\
\text { between model } \\
\text { calculated and } \\
\text { measured heads }\end{array}$} \\
\hline & & Row & Column & $\begin{array}{l}\text { Model } \\
\text { layor }\end{array}$ & & & \\
\hline $\begin{array}{r}-21 \\
-42 \\
-14 \\
17 \\
14 \\
68\end{array}$ & $\begin{array}{r}-47 \\
-1 \\
76 \\
-84 \\
-10 \\
-20\end{array}$ & $\begin{array}{l}7 \\
36 \\
33 \\
28 \\
51 \\
28\end{array}$ & $\begin{array}{r}65 \\
16 \\
14 \\
16 \\
7 \\
24\end{array}$ & $\begin{array}{l}1 \\
1 \\
1 \\
1 \\
1 \\
1\end{array}$ & $\begin{array}{l}797 \\
697 \\
700 \\
678 \\
781 \\
682\end{array}$ & $\begin{array}{l}701 \\
608 \\
621 \\
611 \\
742 \\
651\end{array}$ & $\begin{array}{l}96 \\
89 \\
79 \\
67 \\
39 \\
31\end{array}$ \\
\hline $\begin{array}{r}17 \\
-77 \\
-11 \\
-91 \\
-36\end{array}$ & $\begin{array}{r}77 \\
11 \\
30 \\
-7 \\
-22\end{array}$ & $\begin{array}{r}39 \\
47 \\
54 \\
4 \\
4\end{array}$ & $\begin{array}{r}17 \\
22 \\
9 \\
6 \\
52\end{array}$ & $\begin{array}{l}1 \\
1 \\
1 \\
1 \\
1\end{array}$ & $\begin{array}{l}694 \\
722 \\
783 \\
913 \\
848\end{array}$ & $\begin{array}{l}664 \\
694 \\
755 \\
888 \\
823\end{array}$ & $\begin{array}{l}30 \\
28 \\
28 \\
25 \\
25\end{array}$ \\
\hline $\begin{array}{r}-59 \\
54 \\
89 \\
-16 \\
-36\end{array}$ & $\begin{array}{r}42 \\
-55 \\
-23 \\
32 \\
65\end{array}$ & $\begin{array}{l}24 \\
11 \\
46 \\
11 \\
11\end{array}$ & $\begin{array}{l}22 \\
16 \\
48 \\
19 \\
17\end{array}$ & $\begin{array}{l}1 \\
1 \\
1 \\
1 \\
1\end{array}$ & $\begin{array}{l}677 \\
713 \\
673 \\
697 \\
706\end{array}$ & $\begin{array}{l}657 \\
698 \\
665 \\
689 \\
701\end{array}$ & $\begin{array}{r}20 \\
15 \\
8 \\
8 \\
5\end{array}$ \\
\hline $\begin{array}{r}21 \\
87 \\
-7 \\
-76 \\
62\end{array}$ & $\begin{array}{l}-33 \\
-37 \\
-13 \\
-19 \\
-68\end{array}$ & $\begin{array}{l}16 \\
22 \\
25 \\
26 \\
10\end{array}$ & $\begin{array}{l}64 \\
23 \\
27 \\
39 \\
31\end{array}$ & $\begin{array}{l}1 \\
1 \\
1 \\
1 \\
1\end{array}$ & $\begin{array}{l}706 \\
674 \\
681 \\
685 \\
709\end{array}$ & $\begin{array}{l}702 \\
670 \\
678 \\
684 \\
709\end{array}$ & $\begin{array}{l}4 \\
4 \\
3 \\
1 \\
0\end{array}$ \\
\hline $\begin{array}{r}-15 \\
9 \\
-51 \\
61 \\
76\end{array}$ & $\begin{array}{r}35 \\
-69 \\
71 \\
-85 \\
81\end{array}$ & $\begin{array}{r}26 \\
29 \\
12 \\
4 \\
3\end{array}$ & $\begin{array}{r}41 \\
41 \\
24 \\
5 \\
3\end{array}$ & $\begin{array}{l}1 \\
1 \\
1 \\
1 \\
1\end{array}$ & $\begin{array}{l}685 \\
680 \\
676 \\
924 \\
920\end{array}$ & $\begin{array}{l}688 \\
685 \\
688 \\
937 \\
933\end{array}$ & $\begin{array}{r}-3 \\
-5 \\
-12 \\
-13 \\
-14\end{array}$ \\
\hline $\begin{array}{l}-24 \\
-89 \\
-30 \\
-19 \\
-20\end{array}$ & $\begin{array}{r}-71 \\
-66 \\
38 \\
-44 \\
61\end{array}$ & $\begin{array}{r}12 \\
46 \\
3 \\
6 \\
29\end{array}$ & $\begin{array}{r}25 \\
3 \\
5 \\
14 \\
6\end{array}$ & $\begin{array}{l}1 \\
1 \\
1 \\
1 \\
1\end{array}$ & $\begin{array}{l}669 \\
821 \\
893 \\
801 \\
818\end{array}$ & $\begin{array}{l}683 \\
850 \\
925 \\
857 \\
878\end{array}$ & $\begin{array}{l}-14 \\
-29 \\
-32 \\
-56 \\
-60\end{array}$ \\
\hline $\begin{array}{r}-69 \\
-88 \\
-97 \\
-9 \\
39\end{array}$ & $\begin{array}{r}18 \\
88 \\
-77 \\
-56 \\
23\end{array}$ & $\begin{array}{r}3 \\
10 \\
54 \\
50 \\
48\end{array}$ & $\begin{array}{l}8 \\
3 \\
4 \\
9 \\
8\end{array}$ & $\begin{array}{l}1 \\
7 \\
7 \\
7 \\
7\end{array}$ & $\begin{array}{r}895 \\
1005 \\
796 \\
826 \\
799\end{array}$ & $\begin{array}{l}955 \\
919 \\
714 \\
747 \\
730\end{array}$ & $\begin{array}{r}-60 \\
86 \\
82 \\
79 \\
69\end{array}$ \\
\hline $\begin{array}{r}13 \\
1 \\
-62 \\
-2 \\
-25\end{array}$ & $\begin{array}{r}57 \\
-39 \\
-24 \\
46 \\
52\end{array}$ & $\begin{array}{l}49 \\
54 \\
50 \\
50 \\
40\end{array}$ & $\begin{array}{r}5 \\
5 \\
11 \\
4 \\
26\end{array}$ & $\begin{array}{l}7 \\
7 \\
7 \\
7 \\
7\end{array}$ & $\begin{array}{l}808 \\
804 \\
846 \\
827 \\
763\end{array}$ & $\begin{array}{l}744 \\
741 \\
793 \\
780 \\
724\end{array}$ & $\begin{array}{l}64 \\
63 \\
53 \\
47 \\
39\end{array}$ \\
\hline $\begin{array}{r}97 \\
-51 \\
95 \\
59 \\
-49\end{array}$ & $\begin{array}{r}-80 \\
-64 \\
59 \\
4 \\
-10\end{array}$ & $\begin{array}{l}51 \\
35 \\
51 \\
49 \\
56\end{array}$ & $\begin{array}{l}5 \\
4 \\
6 \\
8 \\
5\end{array}$ & $\begin{array}{l}7 \\
7 \\
7 \\
7 \\
7\end{array}$ & $\begin{array}{l}777 \\
922 \\
786 \\
803 \\
845\end{array}$ & $\begin{array}{l}741 \\
887 \\
752 \\
780 \\
826\end{array}$ & $\begin{array}{l}36 \\
35 \\
34 \\
23 \\
19\end{array}$ \\
\hline $\begin{array}{r}-69 \\
14 \\
61 \\
81 \\
10\end{array}$ & $\begin{array}{r}19 \\
-43 \\
-56 \\
-17 \\
13\end{array}$ & $\begin{array}{r}52 \\
6 \\
53 \\
6 \\
47\end{array}$ & $\begin{array}{r}2 \\
25 \\
7 \\
9 \\
13\end{array}$ & $\begin{array}{l}7 \\
7 \\
7 \\
7 \\
7\end{array}$ & $\begin{array}{l}865 \\
864 \\
827 \\
887 \\
805\end{array}$ & $\begin{array}{l}847 \\
852 \\
818 \\
879 \\
798\end{array}$ & $\begin{array}{r}18 \\
12 \\
9 \\
8 \\
7\end{array}$ \\
\hline $\begin{array}{l}-79 \\
-55 \\
-72 \\
-21 \\
-81\end{array}$ & $\begin{array}{r}0 \\
74 \\
-52 \\
30 \\
-22\end{array}$ & $\begin{array}{r}4 \\
51 \\
46 \\
7 \\
37\end{array}$ & $\begin{array}{r}46 \\
3 \\
48 \\
22 \\
3\end{array}$ & $\begin{array}{l}7 \\
7 \\
7 \\
7 \\
7\end{array}$ & $\begin{array}{l}892 \\
842 \\
743 \\
828 \\
927\end{array}$ & $\begin{array}{l}885 \\
835 \\
737 \\
824 \\
923\end{array}$ & $\begin{array}{l}7 \\
7 \\
6 \\
4 \\
4\end{array}$ \\
\hline $\begin{array}{r}-59 \\
-80 \\
48 \\
58 \\
-99\end{array}$ & $\begin{array}{r}-55 \\
82 \\
-12 \\
-5 \\
-24\end{array}$ & $\begin{array}{r}34 \\
47 \\
42 \\
2 \\
5\end{array}$ & $\begin{array}{r}4 \\
2 \\
3 \\
40 \\
9\end{array}$ & $\begin{array}{l}7 \\
7 \\
7 \\
7 \\
7\end{array}$ & $\begin{array}{l}923 \\
884 \\
906 \\
895 \\
865\end{array}$ & $\begin{array}{l}920 \\
881 \\
906 \\
899 \\
870\end{array}$ & $\begin{array}{r}3 \\
3 \\
0 \\
-4 \\
-5\end{array}$ \\
\hline
\end{tabular}


Appendix C.--True differences between model-calculated and observed heads (residuals) for model calibration--Continued

\begin{tabular}{|c|c|c|c|c|c|c|c|}
\hline \multirow{2}{*}{$\begin{array}{l}\text { Percent } \\
\text { displacement } \\
\text { from center } \\
\text { to edge of } \\
\text { cell in y- } \\
\text { direction }\end{array}$} & \multirow{2}{*}{$\begin{array}{l}\text { Percent } \\
\text { displacement } \\
\text { from center } \\
\text { to edge of } \\
\text { cell in } x- \\
\text { direction }\end{array}$} & \multicolumn{3}{|c|}{ Cell Location } & \multirow{2}{*}{$\begin{array}{c}\text { Model } \\
\text { calculated } \\
\text { head }\end{array}$} & \multirow{2}{*}{$\begin{array}{l}\text { Median of } \\
\text { measured } \\
\text { heads, } \\
1971-80\end{array}$} & \multirow{2}{*}{$\begin{array}{l}\text { Difference } \\
\text { between model } \\
\text { calculated and } \\
\text { measured heads }\end{array}$} \\
\hline & & Row & Column & $\begin{array}{l}\text { Model } \\
\text { layer }\end{array}$ & & & \\
\hline $\begin{array}{r}-29 \\
-79 \\
-90 \\
66 \\
42\end{array}$ & $\begin{array}{r}60 \\
75 \\
27 \\
-26 \\
88\end{array}$ & $\begin{array}{r}8 \\
52 \\
11 \\
41 \\
54\end{array}$ & $\begin{array}{r}21 \\
7 \\
9 \\
6 \\
10\end{array}$ & $\begin{array}{l}7 \\
7 \\
7 \\
7 \\
7\end{array}$ & $\begin{array}{l}828 \\
812 \\
892 \\
861 \\
875\end{array}$ & $\begin{array}{l}835 \\
831 \\
914 \\
886 \\
905\end{array}$ & $\begin{array}{l}-7 \\
-19 \\
-22 \\
-25 \\
-30\end{array}$ \\
\hline $\begin{array}{r}-80 \\
-75 \\
4 \\
-38 \\
-72\end{array}$ & $\begin{array}{r}11 \\
7 \\
-24 \\
67 \\
-46\end{array}$ & $\begin{array}{r}11 \\
9 \\
9 \\
46 \\
42\end{array}$ & $\begin{array}{r}50 \\
65 \\
55 \\
21 \\
5\end{array}$ & $\begin{array}{l}7 \\
8 \\
8 \\
8 \\
8\end{array}$ & $\begin{array}{l}824 \\
814 \\
934 \\
790 \\
927\end{array}$ & $\begin{array}{l}897 \\
694 \\
842 \\
707 \\
850\end{array}$ & $\begin{array}{r}-73 \\
120 \\
92 \\
83 \\
77\end{array}$ \\
\hline $\begin{array}{r}-23 \\
-89 \\
52 \\
-99 \\
-94\end{array}$ & $\begin{array}{r}58 \\
18 \\
-73 \\
80 \\
-4\end{array}$ & $\begin{array}{l}47 \\
49 \\
51 \\
38 \\
38\end{array}$ & $\begin{array}{r}6 \\
54 \\
9 \\
47 \\
49\end{array}$ & $\begin{array}{l}8 \\
8 \\
8 \\
8 \\
8\end{array}$ & $\begin{array}{l}812 \\
807 \\
876 \\
746 \\
736\end{array}$ & $\begin{array}{l}736 \\
732 \\
806 \\
676 \\
667\end{array}$ & $\begin{array}{l}76 \\
75 \\
70 \\
70 \\
69\end{array}$ \\
\hline $\begin{array}{r}-41 \\
25 \\
-49 \\
-48 \\
-74\end{array}$ & $\begin{array}{r}18 \\
95 \\
-74 \\
-5 \\
13\end{array}$ & $\begin{array}{l}52 \\
46 \\
36 \\
51 \\
41\end{array}$ & $\begin{array}{l}64 \\
19 \\
48 \\
58 \\
62\end{array}$ & $\begin{array}{l}8 \\
8 \\
8 \\
8 \\
8\end{array}$ & $\begin{array}{l}759 \\
794 \\
733 \\
794 \\
808\end{array}$ & $\begin{array}{l}698 \\
734 \\
674 \\
736 \\
750\end{array}$ & $\begin{array}{l}61 \\
60 \\
59 \\
58 \\
58\end{array}$ \\
\hline $\begin{array}{r}-34 \\
-94 \\
3 \\
-36 \\
-66\end{array}$ & $\begin{array}{r}39 \\
-27 \\
72 \\
-2 \\
-30\end{array}$ & $\begin{array}{l}49 \\
38 \\
42 \\
47 \\
26\end{array}$ & $\begin{array}{r}9 \\
36 \\
10 \\
51 \\
35\end{array}$ & $\begin{array}{l}8 \\
8 \\
8 \\
8 \\
8\end{array}$ & $\begin{array}{l}820 \\
752 \\
803 \\
773 \\
729\end{array}$ & $\begin{array}{l}763 \\
695 \\
747 \\
720 \\
677\end{array}$ & $\begin{array}{l}57 \\
57 \\
56 \\
53 \\
52\end{array}$ \\
\hline $\begin{array}{r}33 \\
-32 \\
-79 \\
-85 \\
-32\end{array}$ & $\begin{array}{r}-11 \\
47 \\
75 \\
-55 \\
53\end{array}$ & $\begin{array}{l}49 \\
44 \\
52 \\
46 \\
16\end{array}$ & $\begin{array}{r}56 \\
25 \\
7 \\
22 \\
60\end{array}$ & $\begin{array}{l}8 \\
8 \\
8 \\
8 \\
8\end{array}$ & $\begin{array}{l}783 \\
756 \\
850 \\
791 \\
849\end{array}$ & $\begin{array}{l}732 \\
706 \\
801 \\
743 \\
802\end{array}$ & $\begin{array}{l}51 \\
50 \\
49 \\
48 \\
47\end{array}$ \\
\hline $\begin{array}{r}28 \\
16 \\
8 \\
15 \\
46\end{array}$ & $\begin{array}{r}79 \\
-18 \\
-11 \\
-75 \\
37\end{array}$ & $\begin{array}{l}50 \\
45 \\
42 \\
55 \\
38\end{array}$ & $\begin{array}{l}56 \\
23 \\
34 \\
12 \\
48\end{array}$ & $\begin{array}{l}8 \\
8 \\
8 \\
8 \\
8\end{array}$ & $\begin{array}{l}803 \\
763 \\
761 \\
987 \\
738\end{array}$ & $\begin{array}{l}757 \\
718 \\
716 \\
942 \\
693\end{array}$ & $\begin{array}{l}46 \\
45 \\
45 \\
45 \\
45\end{array}$ \\
\hline $\begin{array}{r}-7 \\
-1 \\
-96 \\
46 \\
65\end{array}$ & $\begin{array}{r}90 \\
-73 \\
-57 \\
83 \\
-81\end{array}$ & $\begin{array}{l}37 \\
54 \\
51 \\
38 \\
50\end{array}$ & $\begin{array}{l}50 \\
15 \\
60 \\
51 \\
57\end{array}$ & $\begin{array}{l}8 \\
8 \\
8 \\
8 \\
8\end{array}$ & $\begin{array}{l}746 \\
973 \\
766 \\
750 \\
786\end{array}$ & $\begin{array}{l}702 \\
929 \\
724 \\
709 \\
747\end{array}$ & $\begin{array}{l}44 \\
44 \\
42 \\
41 \\
38\end{array}$ \\
\hline $\begin{array}{r}-83 \\
-85 \\
-53 \\
-95 \\
71\end{array}$ & $\begin{array}{r}-72 \\
70 \\
-6 \\
-25 \\
-38\end{array}$ & $\begin{array}{l}47 \\
35 \\
48 \\
50 \\
36\end{array}$ & $\begin{array}{r}49 \\
36 \\
8 \\
17 \\
42\end{array}$ & $\begin{array}{l}8 \\
8 \\
8 \\
8 \\
8\end{array}$ & $\begin{array}{l}784 \\
728 \\
752 \\
912 \\
755\end{array}$ & $\begin{array}{l}746 \\
691 \\
715 \\
876 \\
720\end{array}$ & $\begin{array}{l}38 \\
37 \\
37 \\
36 \\
35\end{array}$ \\
\hline $\begin{array}{r}6 \\
-86 \\
-27 \\
-55 \\
-51\end{array}$ & $\begin{array}{r}-81 \\
-14 \\
82 \\
-90 \\
-98\end{array}$ & $\begin{array}{l}45 \\
26 \\
31 \\
51 \\
35\end{array}$ & $\begin{array}{r}24 \\
7 \\
7 \\
56 \\
6\end{array}$ & $\begin{array}{l}8 \\
8 \\
8 \\
8 \\
8\end{array}$ & $\begin{array}{l}774 \\
930 \\
930 \\
815 \\
926\end{array}$ & $\begin{array}{l}740 \\
897 \\
897 \\
782 \\
893\end{array}$ & $\begin{array}{l}34 \\
33 \\
33 \\
33 \\
33\end{array}$ \\
\hline $\begin{array}{r}33 \\
-11 \\
-14 \\
-84 \\
-59\end{array}$ & $\begin{array}{r}28 \\
57 \\
-42 \\
88 \\
-31\end{array}$ & $\begin{array}{l}42 \\
35 \\
12 \\
52 \\
53\end{array}$ & $\begin{array}{l}47 \\
38 \\
60 \\
18 \\
37\end{array}$ & $\begin{array}{l}8 \\
8 \\
8 \\
8 \\
8\end{array}$ & $\begin{array}{l}743 \\
736 \\
833 \\
946 \\
925\end{array}$ & $\begin{array}{l}711 \\
705 \\
803 \\
917 \\
897\end{array}$ & $\begin{array}{l}32 \\
31 \\
30 \\
29 \\
28\end{array}$ \\
\hline $\begin{array}{r}-49 \\
-46 \\
-70 \\
-74 \\
37\end{array}$ & $\begin{array}{r}65 \\
-18 \\
-97 \\
-95 \\
95\end{array}$ & $\begin{array}{l}52 \\
47 \\
45 \\
52 \\
55\end{array}$ & $\begin{array}{l}43 \\
61 \\
11 \\
52 \\
16\end{array}$ & $\begin{array}{l}8 \\
8 \\
8 \\
8 \\
8\end{array}$ & $\begin{array}{l}901 \\
703 \\
736 \\
861 \\
989\end{array}$ & $\begin{array}{l}873 \\
675 \\
709 \\
834 \\
963\end{array}$ & $\begin{array}{l}28 \\
28 \\
27 \\
27 \\
26\end{array}$ \\
\hline
\end{tabular}


Appendix C.--True differences between model-calculated and observed heads (residuals) for model calibration--Continued

\begin{tabular}{|c|c|c|c|c|c|c|c|}
\hline \multirow{2}{*}{$\begin{array}{l}\text { Percent } \\
\text { displacement } \\
\text { from center } \\
\text { to edge of } \\
\text { cell in y- } \\
\text { direction }\end{array}$} & \multirow{2}{*}{$\begin{array}{l}\text { Percent } \\
\text { displacement } \\
\text { from center } \\
\text { to edge of } \\
\text { cell in } x- \\
\text { direction }\end{array}$} & \multicolumn{3}{|c|}{ Cell Location } & \multirow{2}{*}{$\begin{array}{c}\text { Model } \\
\text { calculated } \\
\text { head }\end{array}$} & \multirow{2}{*}{$\begin{array}{l}\text { Median of } \\
\text { measured } \\
\text { heads, } \\
1971-80\end{array}$} & \multirow{2}{*}{$\begin{array}{l}\text { Difference } \\
\text { between model } \\
\text { calculated and } \\
\text { measured heads }\end{array}$} \\
\hline & & Row & Columm & $\begin{array}{l}\text { Mode1 } \\
\text { layer }\end{array}$ & & & \\
\hline $\begin{array}{r}16 \\
-13 \\
-45 \\
-6 \\
-16\end{array}$ & $\begin{array}{r}89 \\
-87 \\
-53 \\
-1 \\
-21\end{array}$ & $\begin{array}{r}52 \\
47 \\
44 \\
45 \\
4\end{array}$ & $\begin{array}{r}8 \\
59 \\
62 \\
56 \\
62\end{array}$ & $\begin{array}{l}8 \\
8 \\
8 \\
8 \\
8\end{array}$ & $\begin{array}{l}873 \\
708 \\
738 \\
687 \\
894\end{array}$ & $\begin{array}{l}849 \\
684 \\
715 \\
664 \\
872\end{array}$ & $\begin{array}{l}24 \\
24 \\
23 \\
23 \\
22\end{array}$ \\
\hline $\begin{array}{r}-7 \\
-42 \\
-93 \\
41 \\
97\end{array}$ & $\begin{array}{r}-10 \\
-82 \\
-40 \\
30 \\
18\end{array}$ & $\begin{array}{r}14 \\
8 \\
54 \\
20 \\
52\end{array}$ & $\begin{array}{l}60 \\
44 \\
24 \\
12 \\
37\end{array}$ & $\begin{array}{l}8 \\
8 \\
8 \\
8 \\
8\end{array}$ & $\begin{array}{l}844 \\
888 \\
964 \\
877 \\
914\end{array}$ & $\begin{array}{l}822 \\
866 \\
943 \\
856 \\
893\end{array}$ & $\begin{array}{l}22 \\
22 \\
21 \\
21 \\
21\end{array}$ \\
\hline $\begin{array}{r}-73 \\
-33 \\
-7 \\
-51 \\
63\end{array}$ & $\begin{array}{r}-35 \\
55 \\
32 \\
-82 \\
56\end{array}$ & $\begin{array}{l}34 \\
22 \\
14 \\
10 \\
50\end{array}$ & $\begin{array}{r}8 \\
8 \\
9 \\
42 \\
55\end{array}$ & $\begin{array}{l}8 \\
8 \\
8 \\
8 \\
8\end{array}$ & $\begin{array}{l}897 \\
929 \\
936 \\
879 \\
815\end{array}$ & $\begin{array}{l}877 \\
910 \\
917 \\
860 \\
796\end{array}$ & $\begin{array}{l}20 \\
19 \\
19 \\
19 \\
19\end{array}$ \\
\hline $\begin{array}{r}38 \\
65 \\
-57 \\
-19 \\
35\end{array}$ & $\begin{array}{r}-84 \\
84 \\
-61 \\
-24 \\
-31\end{array}$ & $\begin{array}{r}8 \\
18 \\
50 \\
53 \\
50\end{array}$ & $\begin{array}{l}18 \\
40 \\
60 \\
13 \\
12\end{array}$ & $\begin{array}{l}8 \\
8 \\
8 \\
8 \\
8\end{array}$ & $\begin{array}{l}854 \\
817 \\
741 \\
944 \\
909\end{array}$ & $\begin{array}{l}835 \\
798 \\
723 \\
926 \\
891\end{array}$ & $\begin{array}{l}19 \\
19 \\
18 \\
18 \\
18\end{array}$ \\
\hline $\begin{array}{l}-66 \\
-10 \\
-14 \\
-40 \\
-18\end{array}$ & $\begin{array}{l}62 \\
17 \\
86 \\
74 \\
97\end{array}$ & $\begin{array}{l}54 \\
29 \\
38 \\
29 \\
53\end{array}$ & $\begin{array}{l}31 \\
47 \\
41 \\
42 \\
12\end{array}$ & $\begin{array}{l}8 \\
8 \\
8 \\
8 \\
8\end{array}$ & $\begin{array}{l}952 \\
750 \\
773 \\
702 \\
930\end{array}$ & $\begin{array}{l}934 \\
732 \\
756 \\
685 \\
914\end{array}$ & $\begin{array}{l}18 \\
18 \\
17 \\
17 \\
16\end{array}$ \\
\hline $\begin{array}{r}87 \\
81 \\
-4 \\
-52 \\
-81\end{array}$ & $\begin{array}{r}20 \\
13 \\
0 \\
-69 \\
10\end{array}$ & $\begin{array}{l}52 \\
50 \\
46 \\
39 \\
29\end{array}$ & $\begin{array}{l}31 \\
19 \\
25 \\
12 \\
43\end{array}$ & $\begin{array}{l}8 \\
8 \\
8 \\
8 \\
8\end{array}$ & $\begin{array}{l}933 \\
916 \\
810 \\
811 \\
713\end{array}$ & $\begin{array}{l}917 \\
900 \\
795 \\
797 \\
699\end{array}$ & $\begin{array}{l}16 \\
16 \\
15 \\
14 \\
14\end{array}$ \\
\hline $\begin{array}{r}-48 \\
-98 \\
94 \\
34 \\
-47\end{array}$ & $\begin{array}{r}80 \\
-8 \\
-18 \\
-99 \\
42\end{array}$ & $\begin{array}{l}56 \\
51 \\
11 \\
34 \\
25\end{array}$ & $\begin{array}{l}30 \\
39 \\
21 \\
11 \\
12\end{array}$ & $\begin{array}{l}8 \\
8 \\
8 \\
8 \\
8\end{array}$ & $\begin{array}{l}963 \\
904 \\
832 \\
860 \\
869\end{array}$ & $\begin{array}{l}949 \\
890 \\
818 \\
846 \\
856\end{array}$ & $\begin{array}{l}14 \\
14 \\
14 \\
14 \\
13\end{array}$ \\
\hline $\begin{array}{r}-5 \\
62 \\
38 \\
1 \\
97\end{array}$ & $\begin{array}{r}13 \\
2 \\
-26 \\
32 \\
-46\end{array}$ & $\begin{array}{l}15 \\
10 \\
28 \\
41 \\
32\end{array}$ & $\begin{array}{l}58 \\
31 \\
43 \\
48 \\
10\end{array}$ & $\begin{array}{l}8 \\
8 \\
8 \\
8 \\
8\end{array}$ & $\begin{array}{l}892 \\
853 \\
715 \\
724 \\
882\end{array}$ & $\begin{array}{l}879 \\
840 \\
702 \\
712 \\
870\end{array}$ & $\begin{array}{l}13 \\
13 \\
13 \\
12 \\
12\end{array}$ \\
\hline $\begin{array}{r}14 \\
-23 \\
52 \\
36 \\
0\end{array}$ & $\begin{array}{r}10 \\
-60 \\
-51 \\
41 \\
-20\end{array}$ & $\begin{array}{r}44 \\
11 \\
56 \\
17 \\
4\end{array}$ & $\begin{array}{l}30 \\
31 \\
45 \\
10 \\
57\end{array}$ & $\begin{array}{l}8 \\
8 \\
8 \\
8 \\
8\end{array}$ & $\begin{array}{l}787 \\
842 \\
890 \\
914 \\
917\end{array}$ & $\begin{array}{l}775 \\
830 \\
878 \\
903 \\
906\end{array}$ & $\begin{array}{l}12 \\
12 \\
12 \\
11 \\
11\end{array}$ \\
\hline $\begin{array}{r}-83 \\
-33 \\
79 \\
38 \\
-33\end{array}$ & $\begin{array}{r}-70 \\
-51 \\
-18 \\
84 \\
-73\end{array}$ & $\begin{array}{l}36 \\
34 \\
37 \\
28 \\
41\end{array}$ & $\begin{array}{l}13 \\
12 \\
31 \\
15 \\
35\end{array}$ & $\begin{array}{l}8 \\
8 \\
8 \\
8 \\
8\end{array}$ & $\begin{array}{l}818 \\
842 \\
726 \\
811 \\
763\end{array}$ & $\begin{array}{l}808 \\
832 \\
716 \\
801 \\
753\end{array}$ & $\begin{array}{l}10 \\
10 \\
10 \\
10 \\
10\end{array}$ \\
\hline $\begin{array}{r}77 \\
89 \\
57 \\
-36 \\
30\end{array}$ & $\begin{array}{r}-85 \\
44 \\
-84 \\
76 \\
-15\end{array}$ & $\begin{array}{l}54 \\
15 \\
51 \\
15 \\
45\end{array}$ & $\begin{array}{l}23 \\
57 \\
34 \\
37 \\
14\end{array}$ & $\begin{array}{l}8 \\
8 \\
8 \\
8 \\
8\end{array}$ & $\begin{array}{l}966 \\
898 \\
916 \\
830 \\
725\end{array}$ & $\begin{array}{l}956 \\
888 \\
907 \\
821 \\
716\end{array}$ & $\begin{array}{r}10 \\
10 \\
9 \\
9 \\
9\end{array}$ \\
\hline $\begin{array}{r}-24 \\
76 \\
1 \\
17 \\
-76\end{array}$ & $\begin{array}{r}-17 \\
-95 \\
-8 \\
-10 \\
55\end{array}$ & $\begin{array}{l}35 \\
53 \\
48 \\
56 \\
48\end{array}$ & $\begin{array}{r}8 \\
18 \\
49 \\
36 \\
49\end{array}$ & $\begin{array}{l}8 \\
8 \\
8 \\
8 \\
8\end{array}$ & $\begin{array}{l}893 \\
958 \\
840 \\
936 \\
817\end{array}$ & $\begin{array}{l}884 \\
950 \\
832 \\
928 \\
809\end{array}$ & $\begin{array}{l}8 \\
8 \\
8 \\
8 \\
8\end{array}$ \\
\hline
\end{tabular}


Appendix C.--True differences between model-calculated and observed heads (residuals) for model calibration--Continued

\begin{tabular}{|c|c|c|c|c|c|c|c|}
\hline \multirow{2}{*}{$\begin{array}{l}\text { Percent } \\
\text { displacement } \\
\text { from center } \\
\text { to edge of } \\
\text { cell in y- } \\
\text { direction }\end{array}$} & \multirow{2}{*}{$\begin{array}{l}\text { Percent } \\
\text { displacement } \\
\text { from center } \\
\text { to edge of } \\
\text { cell in } x- \\
\text { direction }\end{array}$} & \multicolumn{3}{|c|}{ Cell Location } & \multirow{2}{*}{$\begin{array}{c}\text { Model } \\
\text { calculated } \\
\text { head }\end{array}$} & \multirow{2}{*}{$\begin{array}{l}\text { Median of } \\
\text { measured } \\
\text { heads, } \\
1971-80\end{array}$} & \multirow{2}{*}{$\begin{array}{l}\text { Difference } \\
\text { between model } \\
\text { calculated and } \\
\text { measured heads }\end{array}$} \\
\hline & & Row & Column & $\begin{array}{l}\text { Mode1 } \\
\text { layer }\end{array}$ & & & \\
\hline $\begin{array}{r}-27 \\
58 \\
-95 \\
-38 \\
99\end{array}$ & $\begin{array}{r}8 \\
76 \\
-66 \\
58 \\
-70\end{array}$ & $\begin{array}{l}31 \\
39 \\
50 \\
55 \\
52\end{array}$ & $\begin{array}{r}59 \\
9 \\
42 \\
40 \\
29\end{array}$ & $\begin{array}{l}8 \\
8 \\
8 \\
8 \\
8\end{array}$ & $\begin{array}{l}839 \\
855 \\
885 \\
921 \\
936\end{array}$ & $\begin{array}{l}831 \\
848 \\
878 \\
914 \\
929\end{array}$ & $\begin{array}{l}8 \\
7 \\
7 \\
7 \\
7\end{array}$ \\
\hline $\begin{array}{r}42 \\
50 \\
-24 \\
69 \\
-16\end{array}$ & $\begin{array}{r}60 \\
26 \\
3 \\
68 \\
93\end{array}$ & $\begin{array}{l}10 \\
29 \\
49 \\
49 \\
21\end{array}$ & $\begin{array}{l}28 \\
60 \\
40 \\
59 \\
15\end{array}$ & $\begin{array}{l}8 \\
8 \\
8 \\
8 \\
8\end{array}$ & $\begin{array}{l}848 \\
821 \\
878 \\
732 \\
829\end{array}$ & $\begin{array}{l}842 \\
815 \\
872 \\
726 \\
823\end{array}$ & $\begin{array}{l}6 \\
6 \\
6 \\
6 \\
6\end{array}$ \\
\hline $\begin{array}{r}-93 \\
-66 \\
34 \\
-3 \\
92\end{array}$ & $\begin{array}{r}13 \\
-29 \\
-35 \\
99 \\
0\end{array}$ & $\begin{array}{l}56 \\
54 \\
52 \\
41 \\
52\end{array}$ & $\begin{array}{l}38 \\
49 \\
60 \\
22 \\
58\end{array}$ & $\begin{array}{l}8 \\
8 \\
8 \\
8 \\
8\end{array}$ & $\begin{array}{l}924 \\
888 \\
783 \\
754 \\
802\end{array}$ & $\begin{array}{l}918 \\
883 \\
778 \\
749 \\
797\end{array}$ & $\begin{array}{l}8 \\
5 \\
5 \\
5 \\
5\end{array}$ \\
\hline $\begin{array}{r}7 \\
38 \\
66 \\
-90 \\
54\end{array}$ & $\begin{array}{r}80 \\
23 \\
46 \\
-64 \\
13\end{array}$ & $\begin{array}{r}28 \\
54 \\
27 \\
8 \\
16\end{array}$ & $\begin{array}{l}21 \\
33 \\
35 \\
55 \\
14\end{array}$ & $\begin{array}{l}8 \\
8 \\
8 \\
8 \\
8\end{array}$ & $\begin{array}{l}770 \\
947 \\
725 \\
936 \\
861\end{array}$ & $\begin{array}{l}766 \\
943 \\
721 \\
932 \\
857\end{array}$ & $\begin{array}{l}4 \\
4 \\
4 \\
4 \\
4\end{array}$ \\
\hline $\begin{array}{r}62 \\
-63 \\
30 \\
8 \\
20\end{array}$ & $\begin{array}{l}-12 \\
-56 \\
-24 \\
-86 \\
-56\end{array}$ & $\begin{array}{r}9 \\
32 \\
53 \\
49 \\
9\end{array}$ & $\begin{array}{l}39 \\
11 \\
52 \\
14 \\
57\end{array}$ & $\begin{array}{l}8 \\
8 \\
8 \\
8 \\
8\end{array}$ & $\begin{array}{l}877 \\
869 \\
868 \\
883 \\
932\end{array}$ & $\begin{array}{l}873 \\
865 \\
864 \\
879 \\
928\end{array}$ & $\begin{array}{l}4 \\
4 \\
4 \\
4 \\
4\end{array}$ \\
\hline $\begin{array}{l}32 \\
33 \\
36 \\
52 \\
98\end{array}$ & $\begin{array}{r}-24 \\
98 \\
-56 \\
29 \\
29\end{array}$ & $\begin{array}{r}14 \\
6 \\
27 \\
33 \\
4\end{array}$ & $\begin{array}{l}38 \\
53 \\
41 \\
33 \\
59\end{array}$ & $\begin{array}{l}8 \\
8 \\
8 \\
8 \\
8\end{array}$ & $\begin{array}{l}840 \\
922 \\
725 \\
728 \\
919\end{array}$ & $\begin{array}{l}838 \\
918 \\
722 \\
725 \\
917\end{array}$ & $\begin{array}{l}4 \\
4 \\
3 \\
3 \\
2\end{array}$ \\
\hline $\begin{array}{r}57 \\
-82 \\
7 \\
34 \\
93\end{array}$ & $\begin{array}{r}7 \\
-81 \\
-23 \\
-72 \\
-95\end{array}$ & $\begin{array}{l}48 \\
28 \\
22 \\
26 \\
14\end{array}$ & $\begin{array}{r}46 \\
37 \\
11 \\
9 \\
35\end{array}$ & $\begin{array}{l}8 \\
8 \\
8 \\
8 \\
8\end{array}$ & $\begin{array}{l}842 \\
733 \\
891 \\
907 \\
828\end{array}$ & $\begin{array}{l}840 \\
731 \\
889 \\
906 \\
827\end{array}$ & $\begin{array}{l}2 \\
2 \\
2 \\
1 \\
1\end{array}$ \\
\hline $\begin{array}{r}1 \\
63 \\
25 \\
19 \\
-59\end{array}$ & $\begin{array}{r}-75 \\
32 \\
-47 \\
56 \\
-42\end{array}$ & $\begin{array}{l}48 \\
50 \\
44 \\
19 \\
44\end{array}$ & $\begin{array}{l}58 \\
52 \\
15 \\
46 \\
48\end{array}$ & $\begin{array}{l}8 \\
8 \\
8 \\
8 \\
8\end{array}$ & $\begin{array}{l}717 \\
838 \\
745 \\
819 \\
746\end{array}$ & $\begin{array}{l}716 \\
837 \\
744 \\
818 \\
745\end{array}$ & $\begin{array}{l}1 \\
1 \\
1 \\
1 \\
1\end{array}$ \\
\hline $\begin{array}{l}-90 \\
-57 \\
-68 \\
-49 \\
-59\end{array}$ & $\begin{array}{r}34 \\
-2 \\
86 \\
-37 \\
65\end{array}$ & $\begin{array}{r}11 \\
21 \\
46 \\
8 \\
30\end{array}$ & $\begin{array}{r}26 \\
46 \\
8 \\
46 \\
52\end{array}$ & $\begin{array}{l}8 \\
8 \\
8 \\
8 \\
8\end{array}$ & $\begin{array}{l}837 \\
797 \\
719 \\
892 \\
826\end{array}$ & $\begin{array}{l}836 \\
796 \\
718 \\
891 \\
825\end{array}$ & $\begin{array}{l}1 \\
1 \\
1 \\
1 \\
1\end{array}$ \\
\hline $\begin{array}{r}-39 \\
-48 \\
-58 \\
84 \\
-34\end{array}$ & $\begin{array}{r}34 \\
-22 \\
-94 \\
48 \\
10\end{array}$ & $\begin{array}{l}49 \\
12 \\
54 \\
11 \\
33\end{array}$ & $\begin{array}{l}45 \\
21 \\
40 \\
44 \\
58\end{array}$ & $\begin{array}{l}8 \\
8 \\
8 \\
8 \\
8\end{array}$ & $\begin{array}{l}863 \\
813 \\
921 \\
879 \\
843\end{array}$ & $\begin{array}{l}863 \\
813 \\
921 \\
879 \\
843\end{array}$ & \\
\hline $\begin{array}{r}11 \\
21 \\
-92 \\
-20 \\
22\end{array}$ & $\begin{array}{r}-11 \\
73 \\
83 \\
4 \\
-71\end{array}$ & $\begin{array}{r}7 \\
41 \\
8 \\
45 \\
10\end{array}$ & $\begin{array}{r}58 \\
12 \\
51 \\
9 \\
37\end{array}$ & $\begin{array}{l}8 \\
8 \\
8 \\
8 \\
8\end{array}$ & $\begin{array}{l}932 \\
790 \\
914 \\
697 \\
864\end{array}$ & $\begin{array}{l}932 \\
790 \\
914 \\
697 \\
865\end{array}$ & $\begin{array}{r}0 \\
- \\
- \\
-1\end{array}$ \\
\hline $\begin{array}{r}-16 \\
71 \\
51 \\
-5 \\
-44\end{array}$ & $\begin{array}{r}-12 \\
-94 \\
63 \\
-84 \\
-56\end{array}$ & $\begin{array}{l}36 \\
13 \\
53 \\
20 \\
12\end{array}$ & $\begin{array}{l}30 \\
51 \\
59 \\
46 \\
25\end{array}$ & $\begin{array}{l}8 \\
8 \\
8 \\
8 \\
8\end{array}$ & $\begin{array}{l}734 \\
889 \\
795 \\
808 \\
819\end{array}$ & $\begin{array}{l}735 \\
890 \\
797 \\
810 \\
821\end{array}$ & $\begin{array}{l}-1 \\
-1 \\
-2 \\
-2 \\
-2\end{array}$ \\
\hline
\end{tabular}


Appendix C.--True differences between model-calculated and observed heads (residuals) for model calibration--Continued

\begin{tabular}{|c|c|c|c|c|c|c|c|}
\hline \multirow{2}{*}{$\begin{array}{l}\text { Percent } \\
\text { displacement } \\
\text { from center } \\
\text { to edge of } \\
\text { cell in y- } \\
\text { direction }\end{array}$} & \multirow{2}{*}{$\begin{array}{l}\text { Percent } \\
\text { displacement } \\
\text { from center } \\
\text { to edge of } \\
\text { celi in } x- \\
\text { direction }\end{array}$} & \multicolumn{3}{|c|}{ Cell Location } & \multirow{2}{*}{$\begin{array}{l}\text { Model } \\
\text { calculated } \\
\text { head }\end{array}$} & \multirow{2}{*}{$\begin{array}{l}\text { Median of } \\
\text { measured } \\
\text { heads, } \\
1971-80\end{array}$} & \multirow{2}{*}{$\begin{array}{l}\text { Difference } \\
\text { between model } \\
\text { calculated and } \\
\text { measured heads }\end{array}$} \\
\hline & & Row & Column & $\begin{array}{l}\text { Model } \\
\text { layer }\end{array}$ & & & \\
\hline $\begin{array}{r}-94 \\
25 \\
-7 \\
-63 \\
0\end{array}$ & $\begin{array}{r}-25 \\
75 \\
-28 \\
79 \\
-34\end{array}$ & $\begin{array}{r}27 \\
8 \\
25 \\
14 \\
6\end{array}$ & $\begin{array}{l}53 \\
53 \\
26 \\
28 \\
60\end{array}$ & $\begin{array}{l}8 \\
8 \\
8 \\
8 \\
8\end{array}$ & $\begin{array}{l}846 \\
926 \\
739 \\
806 \\
913\end{array}$ & $\begin{array}{l}848 \\
928 \\
741 \\
809 \\
916\end{array}$ & $\begin{array}{l}-2 \\
-2 \\
-2 \\
-3 \\
-3\end{array}$ \\
\hline $\begin{array}{r}74 \\
-80 \\
47 \\
35 \\
0\end{array}$ & $\begin{array}{r}40 \\
-19 \\
-21 \\
-32 \\
9\end{array}$ & $\begin{array}{r}47 \\
4 \\
56 \\
13 \\
15\end{array}$ & $\begin{array}{l}36 \\
31 \\
50 \\
22 \\
29\end{array}$ & $\begin{array}{l}8 \\
8 \\
8 \\
8 \\
8\end{array}$ & $\begin{array}{l}862 \\
903 \\
863 \\
807 \\
800\end{array}$ & $\begin{array}{l}865 \\
906 \\
867 \\
811 \\
804\end{array}$ & $\begin{array}{l}-3 \\
-3 \\
-4 \\
-4 \\
-4\end{array}$ \\
\hline $\begin{array}{r}92 \\
42 \\
46 \\
-13 \\
2\end{array}$ & $\begin{array}{r}52 \\
15 \\
32 \\
71 \\
-61\end{array}$ & $\begin{array}{r}44 \\
14 \\
19 \\
45 \\
5\end{array}$ & $\begin{array}{l}17 \\
31 \\
34 \\
13 \\
57\end{array}$ & $\begin{array}{l}8 \\
8 \\
8 \\
8 \\
8\end{array}$ & $\begin{array}{l}744 \\
813 \\
785 \\
700 \\
931\end{array}$ & $\begin{array}{l}748 \\
817 \\
789 \\
705 \\
936\end{array}$ & $\begin{array}{l}-4 \\
-4 \\
-4 \\
-5 \\
-5\end{array}$ \\
\hline $\begin{array}{r}63 \\
84 \\
41 \\
61 \\
-42\end{array}$ & $\begin{array}{r}23 \\
-51 \\
95 \\
43 \\
-86\end{array}$ & $\begin{array}{l}21 \\
36 \\
16 \\
20 \\
18\end{array}$ & $\begin{array}{l}52 \\
12 \\
29 \\
48 \\
55\end{array}$ & $\begin{array}{l}8 \\
8 \\
8 \\
8 \\
8\end{array}$ & $\begin{array}{l}852 \\
835 \\
793 \\
828 \\
886\end{array}$ & $\begin{array}{l}858 \\
841 \\
799 \\
835 \\
893\end{array}$ & $\begin{array}{l}-6 \\
-6 \\
-6 \\
-7 \\
-7\end{array}$ \\
\hline $\begin{array}{r}-64 \\
21 \\
-7 \\
8 \\
83\end{array}$ & $\begin{array}{r}73 \\
-68 \\
-80 \\
-81 \\
46\end{array}$ & $\begin{array}{r}17 \\
16 \\
19 \\
42 \\
9\end{array}$ & $\begin{array}{l}35 \\
59 \\
56 \\
40 \\
46\end{array}$ & $\begin{array}{l}8 \\
8 \\
8 \\
8 \\
8\end{array}$ & $\begin{array}{l}805 \\
872 \\
884 \\
780 \\
892\end{array}$ & $\begin{array}{l}813 \\
880 \\
892 \\
788 \\
900\end{array}$ & $\begin{array}{l}-8 \\
-8 \\
-8 \\
-8 \\
-8\end{array}$ \\
\hline $\begin{array}{r}-72 \\
-61 \\
-26 \\
94 \\
71\end{array}$ & $\begin{array}{r}-15 \\
74 \\
-81 \\
88 \\
64\end{array}$ & $\begin{array}{r}20 \\
6 \\
15 \\
52 \\
13\end{array}$ & $\begin{array}{l}32 \\
40 \\
51 \\
54 \\
29\end{array}$ & $\begin{array}{l}8 \\
8 \\
8 \\
8 \\
8\end{array}$ & $\begin{array}{l}769 \\
888 \\
867 \\
845 \\
810\end{array}$ & $\begin{array}{l}777 \\
896 \\
875 \\
853 \\
818\end{array}$ & $\begin{array}{l}-8 \\
-8 \\
-8 \\
-8 \\
-8\end{array}$ \\
\hline $\begin{array}{r}-43 \\
20 \\
-21 \\
65 \\
66\end{array}$ & $\begin{array}{r}55 \\
-8 \\
-41 \\
26 \\
11\end{array}$ & $\begin{array}{r}11 \\
11 \\
33 \\
18 \\
5\end{array}$ & $\begin{array}{l}17 \\
51 \\
55 \\
18 \\
59\end{array}$ & $\begin{array}{l}8 \\
8 \\
8 \\
8 \\
8\end{array}$ & $\begin{array}{l}841 \\
900 \\
833 \\
812 \\
924\end{array}$ & $\begin{array}{l}850 \\
909 \\
843 \\
822 \\
934\end{array}$ & $\begin{array}{r}-9 \\
-9 \\
-10 \\
-10 \\
-10\end{array}$ \\
\hline $\begin{array}{r}-85 \\
-95 \\
76 \\
-61 \\
81\end{array}$ & $\begin{array}{r}-91 \\
-77 \\
59 \\
87 \\
-11\end{array}$ & $\begin{array}{l}12 \\
12 \\
12 \\
33 \\
34\end{array}$ & $\begin{array}{l}56 \\
34 \\
54 \\
16 \\
18\end{array}$ & $\begin{array}{l}8 \\
8 \\
8 \\
8 \\
8\end{array}$ & $\begin{array}{l}917 \\
837 \\
908 \\
786 \\
781\end{array}$ & $\begin{array}{l}927 \\
847 \\
919 \\
797 \\
792\end{array}$ & $\begin{array}{l}-10 \\
-10 \\
-11 \\
-11 \\
-11\end{array}$ \\
\hline $\begin{array}{r}-50 \\
-32 \\
-64 \\
4 \\
-39\end{array}$ & $\begin{array}{r}-63 \\
75 \\
-15 \\
31 \\
35\end{array}$ & $\begin{array}{l}54 \\
42 \\
27 \\
26 \\
13\end{array}$ & $\begin{array}{l}52 \\
52 \\
58 \\
58 \\
54\end{array}$ & $\begin{array}{l}8 \\
8 \\
8 \\
8 \\
8\end{array}$ & $\begin{array}{l}869 \\
716 \\
850 \\
851 \\
902\end{array}$ & $\begin{array}{l}881 \\
728 \\
862 \\
863 \\
914\end{array}$ & $\begin{array}{l}-12 \\
-12 \\
-12 \\
-12 \\
-12\end{array}$ \\
\hline $\begin{array}{r}54 \\
-46 \\
22 \\
-42 \\
-31\end{array}$ & $\begin{array}{r}-55 \\
91 \\
-98 \\
88 \\
-78\end{array}$ & $\begin{array}{l}11 \\
34 \\
12 \\
53 \\
12\end{array}$ & $\begin{array}{l}16 \\
15 \\
15 \\
54 \\
38\end{array}$ & $\begin{array}{l}8 \\
8 \\
8 \\
8 \\
8\end{array}$ & $\begin{array}{l}847 \\
798 \\
852 \\
851 \\
849\end{array}$ & $\begin{array}{l}860 \\
811 \\
866 \\
865 \\
864\end{array}$ & $\begin{array}{l}-13 \\
-13 \\
-14 \\
-14 \\
-15\end{array}$ \\
\hline $\begin{array}{r}97 \\
-69 \\
-94 \\
-4 \\
9\end{array}$ & $\begin{array}{r}-8 \\
-37 \\
72 \\
22 \\
5\end{array}$ & $\begin{array}{l}22 \\
30 \\
48 \\
53 \\
17\end{array}$ & $\begin{array}{l}34 \\
15 \\
33 \\
60 \\
17\end{array}$ & $\begin{array}{l}8 \\
8 \\
8 \\
8 \\
8\end{array}$ & $\begin{array}{l}755 \\
807 \\
871 \\
786 \\
823\end{array}$ & $\begin{array}{l}770 \\
822 \\
886 \\
802 \\
840\end{array}$ & $\begin{array}{l}-15 \\
-15 \\
-15 \\
-16 \\
-17\end{array}$ \\
\hline $\begin{array}{r}39 \\
-61 \\
56 \\
-6 \\
38\end{array}$ & $\begin{array}{r}-70 \\
34 \\
14 \\
-73 \\
65\end{array}$ & $\begin{array}{l}15 \\
23 \\
52 \\
53 \\
42\end{array}$ & $\begin{array}{l}15 \\
23 \\
56 \\
61 \\
53\end{array}$ & $\begin{array}{l}8 \\
8 \\
8 \\
8 \\
8\end{array}$ & $\begin{array}{l}850 \\
716 \\
823 \\
781 \\
729\end{array}$ & $\begin{array}{l}867 \\
733 \\
840 \\
798 \\
747\end{array}$ & $\begin{array}{l}-17 \\
-17 \\
-17 \\
-17 \\
-18\end{array}$ \\
\hline
\end{tabular}


Appendix C.--True differences between model-calculated and observed heads (residuals) for model calibration--Continued

\begin{tabular}{|c|c|c|c|c|c|c|c|}
\hline \multirow{2}{*}{$\begin{array}{l}\text { Percent } \\
\text { displacement } \\
\text { from center } \\
\text { to edge of } \\
\text { cell in y- } \\
\text { direction }\end{array}$} & \multirow{2}{*}{$\begin{array}{l}\text { Percent } \\
\text { displacement } \\
\text { from center } \\
\text { to edge of } \\
\text { cell in } x- \\
\text { direction }\end{array}$} & \multicolumn{3}{|c|}{ Cell Location } & \multirow{2}{*}{$\begin{array}{c}\text { Model } \\
\text { calculated } \\
\text { head }\end{array}$} & \multirow{2}{*}{$\begin{array}{l}\text { Median of } \\
\text { measured } \\
\text { heads, } \\
1971-80\end{array}$} & \multirow{2}{*}{$\begin{array}{l}\text { Difference } \\
\text { between model } \\
\text { calculated and } \\
\text { measured heads }\end{array}$} \\
\hline & & Row & Column & $\begin{array}{l}\text { Model } \\
\text { layer }\end{array}$ & & & \\
\hline $\begin{array}{r}-87 \\
-19 \\
-64 \\
91 \\
76\end{array}$ & $\begin{array}{r}-6 \\
-14 \\
62 \\
-81 \\
-72\end{array}$ & $\begin{array}{l}19 \\
24 \\
27 \\
24 \\
53\end{array}$ & $\begin{array}{l}12 \\
58 \\
15 \\
61 \\
5\end{array}$ & $\begin{array}{l}8 \\
8 \\
8 \\
8 \\
8\end{array}$ & $\begin{array}{l}878 \\
853 \\
814 \\
802 \\
707\end{array}$ & $\begin{array}{l}896 \\
871 \\
832 \\
821 \\
726\end{array}$ & $\begin{array}{l}-18 \\
-18 \\
-18 \\
-19 \\
-19\end{array}$ \\
\hline $\begin{array}{r}-14 \\
-1 \\
-27 \\
86 \\
-5\end{array}$ & $\begin{array}{r}76 \\
28 \\
-66 \\
-9 \\
38\end{array}$ & $\begin{array}{l}33 \\
55 \\
31 \\
49 \\
43\end{array}$ & $\begin{array}{l}14 \\
47 \\
14 \\
30 \\
53\end{array}$ & $\begin{array}{l}8 \\
8 \\
8 \\
8 \\
8\end{array}$ & $\begin{array}{l}810 \\
893 \\
816 \\
889 \\
724\end{array}$ & $\begin{array}{l}829 \\
912 \\
835 \\
909 \\
744\end{array}$ & $\begin{array}{l}-19 \\
-19 \\
-19 \\
-20 \\
-20\end{array}$ \\
\hline $\begin{array}{r}81 \\
-6 \\
-74 \\
58 \\
84\end{array}$ & $\begin{array}{r}-90 \\
-90 \\
-22 \\
-87 \\
82\end{array}$ & $\begin{array}{l}16 \\
53 \\
45 \\
28 \\
36\end{array}$ & $\begin{array}{l}30 \\
62 \\
55 \\
56 \\
59\end{array}$ & $\begin{array}{l}8 \\
8 \\
8 \\
8 \\
8\end{array}$ & $\begin{array}{l}790 \\
776 \\
716 \\
856 \\
836\end{array}$ & $\begin{array}{l}810 \\
796 \\
737 \\
877 \\
858\end{array}$ & $\begin{array}{l}-20 \\
-20 \\
-21 \\
-21 \\
-22\end{array}$ \\
\hline $\begin{array}{r}86 \\
-49 \\
58 \\
6 \\
-12\end{array}$ & $\begin{array}{l}20 \\
21 \\
-2 \\
48 \\
-9\end{array}$ & $\begin{array}{l}12 \\
38 \\
42 \\
41 \\
39\end{array}$ & $\begin{array}{l}20 \\
18 \\
55 \\
16 \\
15\end{array}$ & $\begin{array}{l}8 \\
8 \\
8 \\
8 \\
8\end{array}$ & $\begin{array}{l}819 \\
765 \\
748 \\
765 \\
786\end{array}$ & $\begin{array}{l}842 \\
789 \\
772 \\
789 \\
810\end{array}$ & $\begin{array}{l}-23 \\
-24 \\
-24 \\
-24 \\
-25\end{array}$ \\
\hline $\begin{array}{r}-47 \\
99 \\
-24 \\
-12 \\
96\end{array}$ & $\begin{array}{r}88 \\
-62 \\
43 \\
59 \\
16\end{array}$ & $\begin{array}{r}6 \\
42 \\
53 \\
34 \\
35\end{array}$ & $\begin{array}{l}52 \\
54 \\
56 \\
17 \\
17\end{array}$ & $\begin{array}{l}8 \\
8 \\
8 \\
8 \\
8\end{array}$ & $\begin{array}{l}915 \\
740 \\
827 \\
778 \\
778\end{array}$ & $\begin{array}{l}940 \\
765 \\
852 \\
804 \\
804\end{array}$ & $\begin{array}{l}-25 \\
-25 \\
-25 \\
-26 \\
-26\end{array}$ \\
\hline $\begin{array}{r}-91 \\
68 \\
0 \\
66 \\
-6\end{array}$ & $\begin{array}{r}59 \\
-11 \\
5 \\
5 \\
49\end{array}$ & $\begin{array}{l}29 \\
28 \\
19 \\
37 \\
54\end{array}$ & $\begin{array}{l}17 \\
55 \\
59 \\
16 \\
55\end{array}$ & $\begin{array}{l}8 \\
8 \\
8 \\
8 \\
8\end{array}$ & $\begin{array}{l}797 \\
850 \\
847 \\
782 \\
843\end{array}$ & $\begin{array}{l}824 \\
878 \\
875 \\
810 \\
872\end{array}$ & $\begin{array}{l}-27 \\
-28 \\
-28 \\
-28 \\
-28\end{array}$ \\
\hline $\begin{array}{r}-71 \\
-39 \\
-72 \\
67 \\
-91\end{array}$ & $\begin{array}{r}-97 \\
-45 \\
-14 \\
1 \\
73\end{array}$ & $\begin{array}{l}29 \\
56 \\
28 \\
22 \\
35\end{array}$ & $\begin{array}{l}19 \\
53 \\
11 \\
37 \\
16\end{array}$ & $\begin{array}{l}8 \\
8 \\
8 \\
8 \\
8\end{array}$ & $\begin{array}{l}786 \\
845 \\
879 \\
766 \\
786\end{array}$ & $\begin{array}{l}816 \\
876 \\
911 \\
798 \\
820\end{array}$ & $\begin{array}{l}-30 \\
-31 \\
-32 \\
-32 \\
-34\end{array}$ \\
\hline $\begin{array}{r}92 \\
53 \\
58 \\
-28 \\
-88\end{array}$ & $\begin{array}{r}55 \\
41 \\
-80 \\
-7 \\
7\end{array}$ & $\begin{array}{l}30 \\
37 \\
39 \\
55 \\
37\end{array}$ & $\begin{array}{l}16 \\
24 \\
17 \\
58 \\
22\end{array}$ & $\begin{array}{l}8 \\
8 \\
8 \\
8 \\
8\end{array}$ & $\begin{array}{l}798 \\
740 \\
766 \\
794 \\
743\end{array}$ & $\begin{array}{l}833 \\
780 \\
806 \\
835 \\
784\end{array}$ & $\begin{array}{l}-35 \\
-40 \\
-40 \\
-41 \\
-41\end{array}$ \\
\hline $\begin{array}{r}-94 \\
96 \\
-13 \\
64 \\
21\end{array}$ & $\begin{array}{r}18 \\
-94 \\
-96 \\
-89 \\
53\end{array}$ & $\begin{array}{l}37 \\
35 \\
41 \\
55 \\
20\end{array}$ & $\begin{array}{l}23 \\
26 \\
58 \\
56 \\
49\end{array}$ & $\begin{array}{l}8 \\
8 \\
8 \\
8 \\
8\end{array}$ & $\begin{array}{l}730 \\
750 \\
794 \\
822 \\
836\end{array}$ & $\begin{array}{l}775 \\
795 \\
841 \\
869 \\
883\end{array}$ & $\begin{array}{l}-45 \\
-45 \\
-47 \\
-47 \\
-47\end{array}$ \\
\hline $\begin{array}{r}-66 \\
-72 \\
-88 \\
-9 \\
-46\end{array}$ & $\begin{array}{r}-99 \\
-44 \\
61 \\
-47 \\
3\end{array}$ & $\begin{array}{l}55 \\
42 \\
55 \\
32 \\
26\end{array}$ & $\begin{array}{l}59 \\
17 \\
57 \\
12 \\
33\end{array}$ & $\begin{array}{l}8 \\
8 \\
8 \\
8 \\
8\end{array}$ & $\begin{array}{l}783 \\
745 \\
808 \\
852 \\
706\end{array}$ & $\begin{array}{l}833 \\
797 \\
861 \\
908 \\
768\end{array}$ & $\begin{array}{l}-50 \\
-52 \\
-53 \\
-56 \\
-62\end{array}$ \\
\hline $\begin{array}{r}-49 \\
88 \\
-98 \\
-5 \\
-17\end{array}$ & $\begin{array}{r}88 \\
17 \\
3 \\
95 \\
55\end{array}$ & $\begin{array}{l}41 \\
44 \\
39 \\
51 \\
50\end{array}$ & $\begin{array}{r}59 \\
7 \\
38 \\
15 \\
21\end{array}$ & $\begin{array}{l}8 \\
8 \\
9 \\
9 \\
9\end{array}$ & $\begin{array}{l}796 \\
817 \\
875 \\
966 \\
931\end{array}$ & $\begin{array}{l}858 \\
890 \\
778 \\
906 \\
880\end{array}$ & $\begin{array}{r}-62 \\
-73 \\
97 \\
60 \\
51\end{array}$ \\
\hline $\begin{array}{l}47 \\
55 \\
28 \\
53 \\
-5\end{array}$ & $\begin{array}{r}24 \\
12 \\
33 \\
-61 \\
21\end{array}$ & $\begin{array}{l}51 \\
40 \\
46 \\
49 \\
44\end{array}$ & $\begin{array}{l}22 \\
48 \\
35 \\
17 \\
18\end{array}$ & $\begin{array}{l}9 \\
9 \\
9 \\
9 \\
9\end{array}$ & $\begin{array}{l}978 \\
761 \\
889 \\
915 \\
788\end{array}$ & $\begin{array}{l}930 \\
723 \\
854 \\
881 \\
758\end{array}$ & $\begin{array}{l}48 \\
38 \\
35 \\
34 \\
30\end{array}$ \\
\hline
\end{tabular}


Appendix C.--True differences between model-calculated and observed heads (residuals) for model calibration--Continued

\begin{tabular}{|c|c|c|c|c|c|c|c|}
\hline \multirow{2}{*}{$\begin{array}{l}\text { Percent } \\
\text { displacement } \\
\text { from center } \\
\text { to edge of } \\
\text { cell in y- } \\
\text { direction }\end{array}$} & \multirow{2}{*}{$\begin{array}{l}\text { Percent } \\
\text { displacement } \\
\text { from center } \\
\text { to edge of } \\
\text { cell in } x^{-} \\
\text {direction }\end{array}$} & \multicolumn{3}{|c|}{ Cell Location } & \multirow{2}{*}{$\begin{array}{c}\text { Model } \\
\text { calculated } \\
\text { head }\end{array}$} & \multirow{2}{*}{$\begin{array}{l}\text { Median of } \\
\text { measured } \\
\text { heads, } \\
1971-80\end{array}$} & \multirow{2}{*}{$\begin{array}{l}\text { Difference } \\
\text { between model } \\
\text { calculated and } \\
\text { measured heads }\end{array}$} \\
\hline & & Row & Column & $\begin{array}{l}\text { Model } \\
\text { layer }\end{array}$ & & & \\
\hline $\begin{array}{r}-39 \\
87 \\
-56 \\
-63 \\
66\end{array}$ & $\begin{array}{r}79 \\
-47 \\
-94 \\
-70 \\
-48\end{array}$ & $\begin{array}{l}38 \\
19 \\
11 \\
36 \\
13\end{array}$ & $\begin{array}{l}10 \\
48 \\
44 \\
38 \\
35\end{array}$ & $\begin{array}{l}9 \\
9 \\
9 \\
9 \\
9 \\
9\end{array}$ & $\begin{array}{l}879 \\
853 \\
888 \\
765 \\
852\end{array}$ & $\begin{array}{l}853 \\
828 \\
864 \\
741 \\
830\end{array}$ & $\begin{array}{l}26 \\
25 \\
24 \\
24 \\
22\end{array}$ \\
\hline $\begin{array}{r}-31 \\
-14 \\
99 \\
35 \\
-43\end{array}$ & $\begin{array}{r}46 \\
-67 \\
-77 \\
-9 \\
2\end{array}$ & $\begin{array}{l}49 \\
10 \\
54 \\
56 \\
21\end{array}$ & $\begin{array}{l}40 \\
19 \\
30 \\
51 \\
44\end{array}$ & $\begin{array}{l}9 \\
9 \\
9 \\
9 \\
9 \\
9\end{array}$ & $\begin{array}{l}892 \\
836 \\
976 \\
876 \\
810\end{array}$ & $\begin{array}{l}870 \\
814 \\
954 \\
858 \\
794\end{array}$ & $\begin{array}{l}22 \\
22 \\
22 \\
18 \\
16\end{array}$ \\
\hline $\begin{array}{r}-43 \\
7 \\
-14 \\
84 \\
-63\end{array}$ & $\begin{array}{r}-83 \\
-43 \\
-94 \\
99 \\
-52\end{array}$ & $\begin{array}{l}21 \\
11 \\
49 \\
11 \\
55\end{array}$ & $\begin{array}{l}51 \\
24 \\
45 \\
40 \\
40\end{array}$ & $\begin{array}{l}9 \\
9 \\
9 \\
9 \\
9\end{array}$ & $\begin{array}{l}867 \\
833 \\
879 \\
881 \\
930\end{array}$ & $\begin{array}{l}852 \\
818 \\
866 \\
869 \\
920\end{array}$ & $\begin{array}{l}15 \\
15 \\
13 \\
12 \\
10\end{array}$ \\
\hline $\begin{array}{r}-89 \\
94 \\
40 \\
68 \\
-2\end{array}$ & $\begin{array}{r}-67 \\
99 \\
39 \\
-56 \\
-52\end{array}$ & $\begin{array}{l}48 \\
45 \\
13 \\
20 \\
14\end{array}$ & $\begin{array}{l}20 \\
31 \\
20 \\
43 \\
37\end{array}$ & $\begin{array}{l}9 \\
9 \\
9 \\
9 \\
9 \\
9\end{array}$ & $\begin{array}{l}888 \\
827 \\
826 \\
818 \\
852\end{array}$ & $\begin{array}{l}879 \\
819 \\
818 \\
813 \\
847\end{array}$ & $\begin{array}{l}9 \\
8 \\
8 \\
5 \\
5\end{array}$ \\
\hline $\begin{array}{r}-23 \\
-39 \\
-76 \\
-5 \\
70\end{array}$ & $\begin{array}{r}-19 \\
26 \\
64 \\
-89 \\
-37\end{array}$ & $\begin{array}{l}22 \\
13 \\
11 \\
20 \\
17\end{array}$ & $\begin{array}{l}12 \\
55 \\
46 \\
58 \\
17\end{array}$ & $\begin{array}{l}9 \\
9 \\
9 \\
9 \\
9\end{array}$ & $\begin{array}{l}885 \\
920 \\
893 \\
890 \\
836\end{array}$ & $\begin{array}{l}880 \\
919 \\
892 \\
890 \\
838\end{array}$ & $\begin{array}{r}5 \\
1 \\
1 \\
-0 \\
-2\end{array}$ \\
\hline $\begin{array}{r}60 \\
34 \\
-14 \\
-74 \\
83\end{array}$ & $\begin{array}{r}91 \\
-37 \\
99 \\
-36 \\
28\end{array}$ & $\begin{array}{r}11 \\
11 \\
10 \\
7 \\
9\end{array}$ & $\begin{array}{l}42 \\
45 \\
14 \\
39 \\
14\end{array}$ & $\begin{array}{l}9 \\
9 \\
9 \\
9 \\
9\end{array}$ & $\begin{array}{l}885 \\
890 \\
860 \\
880 \\
859\end{array}$ & $\begin{array}{l}888 \\
893 \\
864 \\
885 \\
865\end{array}$ & $\begin{array}{l}-3 \\
-3 \\
-4 \\
-5 \\
-6\end{array}$ \\
\hline $\begin{array}{r}-49 \\
-34 \\
-3 \\
-88 \\
-6\end{array}$ & $\begin{array}{r}-37 \\
80 \\
20 \\
60 \\
-17\end{array}$ & $\begin{array}{r}8 \\
12 \\
21 \\
33 \\
11\end{array}$ & $\begin{array}{r}46 \\
16 \\
40 \\
9 \\
15\end{array}$ & $\begin{array}{l}9 \\
9 \\
9 \\
9 \\
9\end{array}$ & $\begin{array}{l}890 \\
848 \\
799 \\
905 \\
857\end{array}$ & $\begin{array}{l}896 \\
854 \\
805 \\
911 \\
865\end{array}$ & $\begin{array}{l}-6 \\
-6 \\
-6 \\
-6 \\
-8\end{array}$ \\
\hline $\begin{array}{r}31 \\
-34 \\
70 \\
56 \\
24\end{array}$ & $\begin{array}{r}54 \\
-56 \\
53 \\
40 \\
-99\end{array}$ & $\begin{array}{l}18 \\
13 \\
17 \\
17 \\
15\end{array}$ & $\begin{array}{l}42 \\
52 \\
31 \\
34 \\
37\end{array}$ & $\begin{array}{l}9 \\
9 \\
9 \\
9 \\
9\end{array}$ & $\begin{array}{l}836 \\
903 \\
805 \\
813 \\
845\end{array}$ & $\begin{array}{l}847 \\
914 \\
817 \\
825 \\
857\end{array}$ & $\begin{array}{l}-11 \\
-11 \\
-12 \\
-12 \\
-12\end{array}$ \\
\hline $\begin{array}{r}57 \\
-37 \\
-15 \\
33 \\
-30\end{array}$ & $\begin{array}{r}41 \\
54 \\
-39 \\
37 \\
-84\end{array}$ & $\begin{array}{r}22 \\
17 \\
51 \\
8 \\
21\end{array}$ & $\begin{array}{l}15 \\
38 \\
31 \\
16 \\
39\end{array}$ & $\begin{array}{l}9 \\
9 \\
9 \\
9 \\
9\end{array}$ & $\begin{array}{l}843 \\
835 \\
935 \\
843 \\
794\end{array}$ & $\begin{array}{l}856 \\
848 \\
950 \\
858 \\
813\end{array}$ & $\begin{array}{l}-13 \\
-13 \\
-15 \\
-15 \\
-19\end{array}$ \\
\hline $\begin{array}{r}-52 \\
19 \\
-4 \\
35 \\
-17\end{array}$ & $\begin{array}{r}68 \\
-34 \\
-37 \\
-37 \\
-11\end{array}$ & $\begin{array}{l}16 \\
19 \\
54 \\
20 \\
17\end{array}$ & $\begin{array}{l}34 \\
35 \\
55 \\
17 \\
36\end{array}$ & $\begin{array}{l}9 \\
9 \\
9 \\
9 \\
9\end{array}$ & $\begin{array}{l}822 \\
797 \\
851 \\
827 \\
824\end{array}$ & $\begin{array}{l}842 \\
818 \\
873 \\
850 \\
848\end{array}$ & $\begin{array}{l}-20 \\
-21 \\
-22 \\
-23 \\
-24\end{array}$ \\
\hline $\begin{array}{r}-64 \\
-49 \\
6 \\
-4 \\
2\end{array}$ & $\begin{array}{r}-23 \\
-72 \\
0 \\
-68 \\
80\end{array}$ & $\begin{array}{l}38 \\
30 \\
19 \\
35 \\
17\end{array}$ & $\begin{array}{l}15 \\
11 \\
37 \\
19 \\
52\end{array}$ & $\begin{array}{l}9 \\
9 \\
9 \\
9 \\
9\end{array}$ & $\begin{array}{l}809 \\
883 \\
807 \\
796 \\
887\end{array}$ & $\begin{array}{l}834 \\
911 \\
836 \\
828 \\
923\end{array}$ & $\begin{array}{l}-25 \\
-28 \\
-29 \\
-32 \\
-36\end{array}$ \\
\hline $\begin{array}{r}42 \\
-81 \\
-37 \\
-76 \\
82\end{array}$ & $\begin{array}{r}60 \\
-95 \\
-40 \\
-96 \\
-78\end{array}$ & $\begin{array}{l}10 \\
29 \\
35 \\
52 \\
52\end{array}$ & $\begin{array}{l}28 \\
20 \\
18 \\
45 \\
39\end{array}$ & $\begin{array}{r}9 \\
9 \\
9 \\
10 \\
10\end{array}$ & $\begin{array}{l}853 \\
802 \\
800 \\
953 \\
965\end{array}$ & $\begin{array}{l}889 \\
839 \\
844 \\
866 \\
888\end{array}$ & $\begin{array}{r}-36 \\
-37 \\
-44 \\
87 \\
77\end{array}$ \\
\hline
\end{tabular}


Appendix C.--True differences between model-calculated and observed heads (residuals) for model calibration--Continued

\begin{tabular}{|c|c|c|c|c|c|c|c|}
\hline \multirow{2}{*}{$\begin{array}{l}\text { Percent } \\
\text { displacement } \\
\text { from center } \\
\text { to edge of } \\
\text { cell in y- } \\
\text { direction }\end{array}$} & \multirow{2}{*}{$\begin{array}{l}\text { Percent } \\
\text { displacement } \\
\text { from center } \\
\text { to edge of } \\
\text { cell in } x- \\
\text { direction }\end{array}$} & \multicolumn{3}{|c|}{ Cell Location } & \multirow{2}{*}{$\begin{array}{c}\text { Model } \\
\text { calculated } \\
\text { head }\end{array}$} & \multirow{2}{*}{$\begin{array}{l}\text { Median of } \\
\text { measured } \\
\text { heads, } \\
1971-80\end{array}$} & \multirow{2}{*}{$\begin{array}{l}\text { Difference } \\
\text { between model } \\
\text { calculated and } \\
\text { measured heads }\end{array}$} \\
\hline & & Row & Column & $\begin{array}{l}\text { Model } \\
\text { layer }\end{array}$ & & & \\
\hline $\begin{array}{r}-14 \\
-79 \\
-54 \\
56 \\
93\end{array}$ & $\begin{array}{r}92 \\
-28 \\
-71 \\
-54 \\
-95\end{array}$ & $\begin{array}{l}12 \\
30 \\
12 \\
27 \\
14\end{array}$ & $\begin{array}{l}38 \\
37 \\
25 \\
19 \\
35\end{array}$ & $\begin{array}{l}10 \\
10 \\
10 \\
10 \\
10\end{array}$ & $\begin{array}{l}888 \\
847 \\
830 \\
854 \\
874\end{array}$ & $\begin{array}{l}860 \\
834 \\
820 \\
846 \\
869\end{array}$ & $\begin{array}{r}28 \\
13 \\
10 \\
8 \\
5\end{array}$ \\
\hline $\begin{array}{r}-10 \\
61 \\
93 \\
-5 \\
33\end{array}$ & $\begin{array}{l}-51 \\
-63 \\
-86 \\
-84 \\
-90\end{array}$ & $\begin{array}{l}15 \\
20 \\
14 \\
20 \\
19\end{array}$ & $\begin{array}{l}40 \\
41 \\
42 \\
46 \\
12\end{array}$ & $\begin{array}{l}10 \\
10 \\
10 \\
10 \\
10\end{array}$ & $\begin{array}{l}885 \\
843 \\
883 \\
858 \\
918\end{array}$ & $\begin{array}{l}883 \\
843 \\
883 \\
858 \\
919\end{array}$ & $\begin{array}{r}2 \\
0 \\
0 \\
-1\end{array}$ \\
\hline $\begin{array}{r}-57 \\
28 \\
21\end{array}$ & $\begin{array}{r}-2 \\
-84 \\
53\end{array}$ & $\begin{array}{l}21 \\
28 \\
20\end{array}$ & $\begin{array}{l}46 \\
16 \\
49\end{array}$ & $\begin{array}{l}10 \\
10 \\
10\end{array}$ & $\begin{array}{l}858 \\
838 \\
900\end{array}$ & $\begin{array}{l}864 \\
874 \\
942\end{array}$ & $\begin{array}{r}-6 \\
-36 \\
-42\end{array}$ \\
\hline
\end{tabular}


Appendix D.--Absolute differences between model-calculated and observed heads (residuals) for model calibration

\begin{tabular}{|c|c|c|c|c|c|c|c|}
\hline \multirow{2}{*}{$\begin{array}{l}\text { Percent } \\
\text { displacement } \\
\text { from center } \\
\text { to edge of } \\
\text { cell in y- } \\
\text { direction }\end{array}$} & \multirow{2}{*}{$\begin{array}{l}\text { Percent } \\
\text { di splacement } \\
\text { from center } \\
\text { to edge of } \\
\text { cell in } x- \\
\text { direction }\end{array}$} & \multicolumn{3}{|c|}{ Cell Location } & \multirow{2}{*}{$\begin{array}{l}\text { Model } \\
\text { calculated } \\
\text { head }\end{array}$} & \multirow{2}{*}{$\begin{array}{l}\text { Median of } \\
\text { measured } \\
\text { heads } \\
1971-80\end{array}$} & \multirow{2}{*}{$\begin{array}{l}\text { Difference } \\
\text { between model } \\
\text { calculated and } \\
\text { measured heads }\end{array}$} \\
\hline & & Row & Column & $\begin{array}{l}\text { Model } \\
\text { layer }\end{array}$ & & & \\
\hline $\begin{array}{r}-21 \\
-42 \\
-14 \\
17 \\
69 \\
20\end{array}$ & $\begin{array}{r}-47 \\
-1 \\
76 \\
-84 \\
18 \\
61\end{array}$ & $\begin{array}{r}7 \\
36 \\
33 \\
28 \\
3 \\
29\end{array}$ & $\begin{array}{r}65 \\
16 \\
14 \\
16 \\
8 \\
6\end{array}$ & $\begin{array}{l}1 \\
1 \\
1 \\
1 \\
1 \\
1\end{array}$ & $\begin{array}{l}797 \\
697 \\
700 \\
678 \\
895 \\
818\end{array}$ & $\begin{array}{l}701 \\
608 \\
621 \\
611 \\
955 \\
878\end{array}$ & $\begin{array}{l}96 \\
89 \\
79 \\
67 \\
60 \\
60\end{array}$ \\
\hline $\begin{array}{r}-19 \\
14 \\
-30 \\
68 \\
17\end{array}$ & $\begin{array}{r}-44 \\
-10 \\
38 \\
-20 \\
77\end{array}$ & $\begin{array}{r}6 \\
51 \\
3 \\
28 \\
39\end{array}$ & $\begin{array}{r}14 \\
7 \\
5 \\
24 \\
17\end{array}$ & $\begin{array}{l}1 \\
1 \\
1 \\
1 \\
1\end{array}$ & $\begin{array}{l}801 \\
781 \\
893 \\
682 \\
694\end{array}$ & $\begin{array}{l}857 \\
742 \\
925 \\
651 \\
664\end{array}$ & $\begin{array}{l}56 \\
39 \\
32 \\
31 \\
30\end{array}$ \\
\hline $\begin{array}{l}-89 \\
-77 \\
-11 \\
-91 \\
-36\end{array}$ & $\begin{array}{r}-86 \\
11 \\
30 \\
-7 \\
-22\end{array}$ & $\begin{array}{r}46 \\
47 \\
54 \\
4 \\
4\end{array}$ & $\begin{array}{r}3 \\
22 \\
9 \\
6 \\
52\end{array}$ & $\begin{array}{l}1 \\
1 \\
1 \\
1 \\
1\end{array}$ & $\begin{array}{l}821 \\
722 \\
783 \\
913 \\
848\end{array}$ & $\begin{array}{l}850 \\
694 \\
755 \\
888 \\
823\end{array}$ & $\begin{array}{l}29 \\
28 \\
28 \\
25 \\
25\end{array}$ \\
\hline $\begin{array}{r}-59 \\
54 \\
-24 \\
76 \\
61\end{array}$ & $\begin{array}{r}42 \\
-55 \\
-71 \\
81 \\
-85\end{array}$ & $\begin{array}{r}24 \\
11 \\
12 \\
3 \\
4\end{array}$ & $\begin{array}{r}22 \\
16 \\
25 \\
3 \\
5\end{array}$ & $\begin{array}{l}1 \\
1 \\
1 \\
1 \\
1\end{array}$ & $\begin{array}{l}677 \\
713 \\
669 \\
920 \\
924\end{array}$ & $\begin{array}{l}657 \\
698 \\
683 \\
933 \\
937\end{array}$ & $\begin{array}{l}20 \\
15 \\
14 \\
14 \\
13\end{array}$ \\
\hline $\begin{array}{r}-51 \\
89 \\
-16 \\
-36 \\
9\end{array}$ & $\begin{array}{r}71 \\
-23 \\
32 \\
65 \\
-69\end{array}$ & $\begin{array}{l}12 \\
46 \\
11 \\
11 \\
29\end{array}$ & $\begin{array}{l}24 \\
48 \\
19 \\
17 \\
41\end{array}$ & $\begin{array}{l}1 \\
1 \\
1 \\
1 \\
1\end{array}$ & $\begin{array}{l}676 \\
673 \\
697 \\
706 \\
680\end{array}$ & $\begin{array}{l}688 \\
665 \\
689 \\
701 \\
685\end{array}$ & $\begin{array}{r}12 \\
8 \\
8 \\
5 \\
5\end{array}$ \\
\hline $\begin{array}{r}21 \\
87 \\
-15 \\
-7 \\
-76\end{array}$ & $\begin{array}{r}-33 \\
-37 \\
35 \\
-13 \\
-19\end{array}$ & $\begin{array}{l}16 \\
22 \\
26 \\
25 \\
26\end{array}$ & $\begin{array}{l}64 \\
23 \\
41 \\
27 \\
39\end{array}$ & $\begin{array}{l}1 \\
1 \\
1 \\
1 \\
1\end{array}$ & $\begin{array}{l}706 \\
674 \\
685 \\
681 \\
685\end{array}$ & $\begin{array}{l}702 \\
670 \\
688 \\
678 \\
684\end{array}$ & $\begin{array}{l}4 \\
4 \\
3 \\
3 \\
1\end{array}$ \\
\hline $\begin{array}{r}62 \\
-88 \\
-97 \\
-9 \\
-80\end{array}$ & $\begin{array}{r}-68 \\
88 \\
-77 \\
-56 \\
11\end{array}$ & $\begin{array}{l}10 \\
10 \\
54 \\
50 \\
11\end{array}$ & $\begin{array}{r}31 \\
3 \\
4 \\
9 \\
50\end{array}$ & $\begin{array}{l}1 \\
7 \\
7 \\
7 \\
7\end{array}$ & $\begin{array}{r}709 \\
1005 \\
796 \\
826 \\
824\end{array}$ & $\begin{array}{l}709 \\
919 \\
714 \\
747 \\
897\end{array}$ & $\begin{array}{r}0 \\
86 \\
82 \\
79 \\
73\end{array}$ \\
\hline $\begin{array}{r}39 \\
13 \\
1 \\
-62 \\
-2\end{array}$ & $\begin{array}{r}23 \\
57 \\
-39 \\
-24 \\
46\end{array}$ & $\begin{array}{l}48 \\
49 \\
54 \\
50 \\
50\end{array}$ & $\begin{array}{r}8 \\
5 \\
5 \\
11 \\
4\end{array}$ & $\begin{array}{l}7 \\
7 \\
7 \\
7 \\
7\end{array}$ & $\begin{array}{l}799 \\
808 \\
804 \\
846 \\
827\end{array}$ & $\begin{array}{l}730 \\
744 \\
741 \\
793 \\
780\end{array}$ & $\begin{array}{l}69 \\
64 \\
63 \\
53 \\
47\end{array}$ \\
\hline $\begin{array}{r}-25 \\
97 \\
-51 \\
95 \\
42\end{array}$ & $\begin{array}{r}52 \\
-80 \\
-64 \\
59 \\
88\end{array}$ & $\begin{array}{l}40 \\
51 \\
35 \\
51 \\
54\end{array}$ & $\begin{array}{r}26 \\
5 \\
4 \\
6 \\
10\end{array}$ & $\begin{array}{l}7 \\
7 \\
7 \\
7 \\
7\end{array}$ & $\begin{array}{l}763 \\
777 \\
922 \\
786 \\
875\end{array}$ & $\begin{array}{l}724 \\
741 \\
887 \\
752 \\
905\end{array}$ & $\begin{array}{l}39 \\
36 \\
35 \\
34 \\
30\end{array}$ \\
\hline $\begin{array}{r}66 \\
59 \\
-90 \\
-49 \\
-79\end{array}$ & $\begin{array}{r}-26 \\
4 \\
27 \\
-10 \\
75\end{array}$ & $\begin{array}{l}41 \\
49 \\
11 \\
56 \\
52\end{array}$ & $\begin{array}{l}6 \\
8 \\
9 \\
5 \\
7\end{array}$ & $\begin{array}{l}7 \\
7 \\
7 \\
7 \\
7\end{array}$ & $\begin{array}{l}861 \\
803 \\
892 \\
845 \\
812\end{array}$ & $\begin{array}{l}886 \\
780 \\
914 \\
826 \\
831\end{array}$ & $\begin{array}{l}25 \\
23 \\
22 \\
19 \\
19\end{array}$ \\
\hline $\begin{array}{r}-69 \\
14 \\
61 \\
81 \\
-29\end{array}$ & $\begin{array}{r}19 \\
-43 \\
-56 \\
-17 \\
60\end{array}$ & $\begin{array}{r}52 \\
6 \\
53 \\
6 \\
8\end{array}$ & $\begin{array}{r}2 \\
25 \\
7 \\
9 \\
21\end{array}$ & $\begin{array}{l}7 \\
7 \\
7 \\
7 \\
7\end{array}$ & $\begin{array}{l}865 \\
864 \\
827 \\
887 \\
828\end{array}$ & $\begin{array}{l}847 \\
852 \\
818 \\
879 \\
835\end{array}$ & $\begin{array}{r}18 \\
12 \\
9 \\
8 \\
7\end{array}$ \\
\hline $\begin{array}{r}10 \\
-79 \\
-55 \\
-72 \\
-99\end{array}$ & $\begin{array}{r}13 \\
0 \\
74 \\
-52 \\
-24\end{array}$ & $\begin{array}{r}47 \\
4 \\
51 \\
46 \\
5\end{array}$ & $\begin{array}{r}13 \\
46 \\
3 \\
48 \\
9\end{array}$ & $\begin{array}{l}7 \\
7 \\
7 \\
7 \\
7\end{array}$ & $\begin{array}{l}805 \\
892 \\
842 \\
743 \\
865\end{array}$ & $\begin{array}{l}798 \\
885 \\
835 \\
737 \\
870\end{array}$ & $\begin{array}{l}7 \\
7 \\
7 \\
6 \\
5\end{array}$ \\
\hline
\end{tabular}


Appendix D.--Absolute differences between model-calculated and observed heads (residuals) for

model calibration--Continued

\begin{tabular}{|c|c|c|c|c|c|c|c|}
\hline \multirow{2}{*}{$\begin{array}{l}\text { Percent } \\
\text { displacement } \\
\text { from center } \\
\text { to edge of } \\
\text { cell in y- } \\
\text { direction }\end{array}$} & \multirow{2}{*}{$\begin{array}{l}\text { Percent } \\
\text { displacement } \\
\text { from center } \\
\text { to edge of } \\
\text { cell in } x- \\
\text { direction }\end{array}$} & \multicolumn{3}{|c|}{ Cell Location } & \multirow{2}{*}{$\begin{array}{l}\text { Model } \\
\text { calculated } \\
\text { head }\end{array}$} & \multirow{2}{*}{$\begin{array}{l}\text { Median of } \\
\text { measured } \\
\text { heads, } \\
1971-80\end{array}$} & \multirow{2}{*}{$\begin{array}{l}\text { Difference } \\
\text { between model } \\
\text { calculated and } \\
\text { measured heads }\end{array}$} \\
\hline & & Ron & Column & $\begin{array}{l}\text { Model } \\
\text { layer }\end{array}$ & & & \\
\hline $\begin{array}{r}-21 \\
58 \\
-81 \\
-59 \\
-80\end{array}$ & $\begin{array}{r}30 \\
-5 \\
-22 \\
-55 \\
82\end{array}$ & $\begin{array}{r}7 \\
2 \\
37 \\
34 \\
47\end{array}$ & $\begin{array}{r}22 \\
40 \\
3 \\
4 \\
2\end{array}$ & $\begin{array}{l}7 \\
7 \\
7 \\
7 \\
7\end{array}$ & $\begin{array}{l}828 \\
895 \\
927 \\
923 \\
884\end{array}$ & $\begin{array}{l}824 \\
899 \\
923 \\
920 \\
881\end{array}$ & $\begin{array}{l}4 \\
4 \\
4 \\
3 \\
3\end{array}$ \\
\hline $\begin{array}{r}48 \\
-75 \\
4 \\
-38 \\
-72\end{array}$ & $\begin{array}{r}-12 \\
7 \\
-24 \\
67 \\
-46\end{array}$ & $\begin{array}{r}42 \\
9 \\
9 \\
46 \\
42\end{array}$ & $\begin{array}{r}3 \\
65 \\
55 \\
21 \\
5\end{array}$ & $\begin{array}{l}7 \\
8 \\
8 \\
8 \\
8\end{array}$ & $\begin{array}{l}906 \\
814 \\
934 \\
790 \\
927\end{array}$ & $\begin{array}{l}906 \\
694 \\
842 \\
707 \\
850\end{array}$ & $\begin{array}{r}0 \\
120 \\
92 \\
83 \\
77\end{array}$ \\
\hline $\begin{array}{r}-23 \\
-89 \\
88 \\
52 \\
-99\end{array}$ & $\begin{array}{r}58 \\
18 \\
17 \\
-73 \\
80\end{array}$ & $\begin{array}{l}47 \\
49 \\
44 \\
51 \\
38\end{array}$ & $\begin{array}{r}6 \\
54 \\
7 \\
9 \\
47\end{array}$ & $\begin{array}{l}8 \\
8 \\
8 \\
8 \\
8\end{array}$ & $\begin{array}{l}812 \\
807 \\
817 \\
876 \\
746\end{array}$ & $\begin{array}{l}736 \\
732 \\
890 \\
806 \\
676\end{array}$ & $\begin{array}{l}76 \\
75 \\
73 \\
70 \\
70\end{array}$ \\
\hline $\begin{array}{l}-94 \\
-49 \\
-46 \\
-41 \\
25\end{array}$ & $\begin{array}{r}-4 \\
88 \\
3 \\
18 \\
95\end{array}$ & $\begin{array}{l}38 \\
41 \\
26 \\
52 \\
46\end{array}$ & $\begin{array}{l}49 \\
59 \\
33 \\
64 \\
19\end{array}$ & $\begin{array}{l}8 \\
8 \\
8 \\
8 \\
8\end{array}$ & $\begin{array}{l}736 \\
796 \\
706 \\
759 \\
794\end{array}$ & $\begin{array}{l}667 \\
858 \\
768 \\
698 \\
734\end{array}$ & $\begin{array}{l}69 \\
62 \\
62 \\
61 \\
60\end{array}$ \\
\hline $\begin{array}{l}-49 \\
-48 \\
-74 \\
-34 \\
-94\end{array}$ & $\begin{array}{r}-74 \\
-5 \\
13 \\
39 \\
-27\end{array}$ & $\begin{array}{l}36 \\
51 \\
41 \\
49 \\
38\end{array}$ & $\begin{array}{r}48 \\
58 \\
62 \\
9 \\
36\end{array}$ & $\begin{array}{l}8 \\
8 \\
8 \\
8 \\
8\end{array}$ & $\begin{array}{l}733 \\
794 \\
808 \\
820 \\
752\end{array}$ & $\begin{array}{l}674 \\
736 \\
750 \\
763 \\
695\end{array}$ & $\begin{array}{l}59 \\
58 \\
58 \\
57 \\
57\end{array}$ \\
\hline $\begin{array}{r}3 \\
-9 \\
-88 \\
-36 \\
-66\end{array}$ & $\begin{array}{r}72 \\
-47 \\
61 \\
-2 \\
-30\end{array}$ & $\begin{array}{l}42 \\
32 \\
55 \\
47 \\
26\end{array}$ & $\begin{array}{l}10 \\
12 \\
57 \\
51 \\
35\end{array}$ & $\begin{array}{l}8 \\
8 \\
8 \\
8 \\
8\end{array}$ & $\begin{array}{l}803 \\
852 \\
808 \\
773 \\
729\end{array}$ & $\begin{array}{l}747 \\
908 \\
861 \\
720 \\
677\end{array}$ & $\begin{array}{l}56 \\
56 \\
53 \\
53 \\
52\end{array}$ \\
\hline $\begin{array}{r}-72 \\
33 \\
-32 \\
-66 \\
-79\end{array}$ & $\begin{array}{r}-44 \\
-11 \\
47 \\
-99 \\
75\end{array}$ & $\begin{array}{l}42 \\
49 \\
44 \\
55 \\
52\end{array}$ & $\begin{array}{r}17 \\
56 \\
25 \\
59 \\
7\end{array}$ & $\begin{array}{l}8 \\
8 \\
8 \\
8 \\
8\end{array}$ & $\begin{array}{l}745 \\
783 \\
756 \\
783 \\
850\end{array}$ & $\begin{array}{l}797 \\
732 \\
706 \\
833 \\
801\end{array}$ & $\begin{array}{l}52 \\
51 \\
50 \\
50 \\
49\end{array}$ \\
\hline $\begin{array}{r}-85 \\
-32 \\
21 \\
64 \\
-13\end{array}$ & $\begin{array}{r}-55 \\
53 \\
53 \\
-89 \\
-96\end{array}$ & $\begin{array}{l}46 \\
16 \\
20 \\
55 \\
41\end{array}$ & $\begin{array}{l}22 \\
60 \\
49 \\
56 \\
58\end{array}$ & $\begin{array}{l}8 \\
8 \\
8 \\
8 \\
8\end{array}$ & $\begin{array}{l}791 \\
849 \\
836 \\
822 \\
794\end{array}$ & $\begin{array}{l}743 \\
802 \\
883 \\
869 \\
841\end{array}$ & $\begin{array}{l}48 \\
47 \\
47 \\
47 \\
47\end{array}$ \\
\hline $\begin{array}{r}28 \\
96 \\
16 \\
-94 \\
8\end{array}$ & $\begin{array}{r}79 \\
-94 \\
-18 \\
18 \\
-11\end{array}$ & $\begin{array}{l}50 \\
35 \\
45 \\
37 \\
42\end{array}$ & $\begin{array}{l}56 \\
26 \\
23 \\
23 \\
34\end{array}$ & $\begin{array}{l}8 \\
8 \\
8 \\
8 \\
8\end{array}$ & $\begin{array}{l}803 \\
750 \\
763 \\
730 \\
761\end{array}$ & $\begin{array}{l}757 \\
795 \\
718 \\
775 \\
716\end{array}$ & $\begin{array}{l}46 \\
45 \\
45 \\
45 \\
45\end{array}$ \\
\hline $\begin{array}{r}15 \\
46 \\
-7 \\
-1 \\
-96\end{array}$ & $\begin{array}{r}-75 \\
37 \\
90 \\
-73 \\
-57\end{array}$ & $\begin{array}{l}55 \\
38 \\
37 \\
54 \\
51\end{array}$ & $\begin{array}{l}12 \\
48 \\
50 \\
15 \\
60\end{array}$ & $\begin{array}{l}8 \\
8 \\
8 \\
8 \\
8\end{array}$ & $\begin{array}{l}987 \\
738 \\
746 \\
973 \\
766\end{array}$ & $\begin{array}{l}942 \\
693 \\
702 \\
929 \\
724\end{array}$ & $\begin{array}{l}45 \\
45 \\
44 \\
44 \\
42\end{array}$ \\
\hline $\begin{array}{r}-88 \\
46 \\
-28 \\
58 \\
53\end{array}$ & $\begin{array}{r}7 \\
83 \\
-7 \\
-80 \\
41\end{array}$ & $\begin{array}{l}37 \\
38 \\
55 \\
39 \\
37\end{array}$ & $\begin{array}{l}22 \\
51 \\
58 \\
17 \\
24\end{array}$ & $\begin{array}{l}8 \\
8 \\
8 \\
8 \\
8\end{array}$ & $\begin{array}{l}743 \\
750 \\
794 \\
766 \\
740\end{array}$ & $\begin{array}{l}784 \\
709 \\
835 \\
806 \\
780\end{array}$ & $\begin{array}{l}41 \\
41 \\
41 \\
40 \\
40\end{array}$ \\
\hline $\begin{array}{r}65 \\
-83 \\
-85 \\
-53 \\
-95\end{array}$ & $\begin{array}{r}-81 \\
-72 \\
70 \\
-6 \\
-25\end{array}$ & $\begin{array}{l}50 \\
47 \\
35 \\
48 \\
50\end{array}$ & $\begin{array}{r}57 \\
49 \\
36 \\
8 \\
17\end{array}$ & $\begin{array}{l}8 \\
8 \\
8 \\
8 \\
8\end{array}$ & $\begin{array}{l}786 \\
784 \\
728 \\
752 \\
912\end{array}$ & $\begin{array}{l}747 \\
746 \\
691 \\
715 \\
876\end{array}$ & $\begin{array}{l}39 \\
38 \\
37 \\
37 \\
36\end{array}$ \\
\hline
\end{tabular}


Appendix D.--Absolute differences between model-calculated and observed heads (residuals) for

model calibration--Continued

\begin{tabular}{|c|c|c|c|c|c|c|c|}
\hline \multirow{2}{*}{$\begin{array}{l}\text { Percent } \\
\text { displacement } \\
\text { from center } \\
\text { to edge of } \\
\text { celi in y- } \\
\text { direction }\end{array}$} & \multirow{2}{*}{$\begin{array}{l}\text { Percent } \\
\text { displacement } \\
\text { from center } \\
\text { to edge of } \\
\text { celi in } x- \\
\text { direction }\end{array}$} & \multicolumn{3}{|c|}{ Cell Location } & \multirow[b]{2}{*}{$\begin{array}{c}\text { Model } \\
\text { calculated } \\
\text { head }\end{array}$} & \multirow{2}{*}{$\begin{array}{l}\text { Median of } \\
\text { measured } \\
\text { heads } \\
1971-80\end{array}$} & \multirow{2}{*}{$\begin{array}{l}\text { Difference } \\
\text { between model } \\
\text { calculated and } \\
\text { measured heads }\end{array}$} \\
\hline & & Row & Column & $\begin{array}{l}\text { Mode1 } \\
\text { layer }\end{array}$ & & & \\
\hline $\begin{array}{r}71 \\
92 \\
-91 \\
6 \\
-86\end{array}$ & $\begin{array}{r}-38 \\
55 \\
73 \\
-81 \\
-14\end{array}$ & $\begin{array}{l}36 \\
30 \\
35 \\
45 \\
26\end{array}$ & $\begin{array}{r}42 \\
16 \\
16 \\
24 \\
7\end{array}$ & $\begin{array}{l}8 \\
8 \\
8 \\
8 \\
8\end{array}$ & $\begin{array}{l}755 \\
798 \\
786 \\
774 \\
930\end{array}$ & $\begin{array}{l}720 \\
833 \\
820 \\
740 \\
897\end{array}$ & $\begin{array}{l}35 \\
35 \\
34 \\
34 \\
33\end{array}$ \\
\hline $\begin{array}{r}-27 \\
-55 \\
-51 \\
67 \\
33\end{array}$ & $\begin{array}{r}82 \\
-90 \\
-98 \\
1 \\
28\end{array}$ & $\begin{array}{l}31 \\
51 \\
35 \\
22 \\
42\end{array}$ & $\begin{array}{r}7 \\
58 \\
6 \\
37 \\
47\end{array}$ & $\begin{array}{l}8 \\
8 \\
8 \\
8 \\
8\end{array}$ & $\begin{array}{l}930 \\
815 \\
926 \\
766 \\
743\end{array}$ & $\begin{array}{l}897 \\
782 \\
893 \\
798 \\
711\end{array}$ & $\begin{array}{l}33 \\
33 \\
33 \\
32 \\
32\end{array}$ \\
\hline $\begin{array}{l}-72 \\
-11 \\
-39 \\
-71 \\
-14\end{array}$ & $\begin{array}{r}-14 \\
57 \\
-45 \\
-97 \\
-42\end{array}$ & $\begin{array}{l}28 \\
35 \\
56 \\
29 \\
12\end{array}$ & $\begin{array}{l}11 \\
38 \\
53 \\
19 \\
60\end{array}$ & $\begin{array}{l}8 \\
8 \\
8 \\
8 \\
8\end{array}$ & $\begin{array}{l}879 \\
736 \\
845 \\
786 \\
833\end{array}$ & $\begin{array}{l}911 \\
705 \\
876 \\
816 \\
803\end{array}$ & $\begin{array}{l}32 \\
31 \\
31 \\
30 \\
30\end{array}$ \\
\hline $\begin{array}{r}-84 \\
-6 \\
-59 \\
-49 \\
66\end{array}$ & $\begin{array}{r}88 \\
49 \\
-31 \\
65 \\
5\end{array}$ & $\begin{array}{l}52 \\
54 \\
53 \\
52 \\
37\end{array}$ & $\begin{array}{l}18 \\
55 \\
37 \\
43 \\
16\end{array}$ & $\begin{array}{l}8 \\
8 \\
8 \\
8 \\
8\end{array}$ & $\begin{array}{l}946 \\
843 \\
925 \\
901 \\
782\end{array}$ & $\begin{array}{l}917 \\
872 \\
897 \\
873 \\
810\end{array}$ & $\begin{array}{l}29 \\
29 \\
28 \\
28 \\
28\end{array}$ \\
\hline $\begin{array}{r}0 \\
68 \\
-46 \\
-91 \\
-70\end{array}$ & $\begin{array}{r}5 \\
-11 \\
-18 \\
59 \\
-97\end{array}$ & $\begin{array}{l}19 \\
28 \\
47 \\
29 \\
45\end{array}$ & $\begin{array}{l}59 \\
55 \\
61 \\
17 \\
11\end{array}$ & $\begin{array}{l}8 \\
8 \\
8 \\
8 \\
8\end{array}$ & $\begin{array}{l}847 \\
850 \\
703 \\
797 \\
736\end{array}$ & $\begin{array}{l}875 \\
878 \\
675 \\
824 \\
709\end{array}$ & $\begin{array}{l}28 \\
28 \\
28 \\
27 \\
27\end{array}$ \\
\hline $\begin{array}{r}-74 \\
96 \\
-12 \\
37 \\
-24\end{array}$ & $\begin{array}{r}-95 \\
16 \\
59 \\
95 \\
43\end{array}$ & $\begin{array}{l}52 \\
35 \\
34 \\
55 \\
53\end{array}$ & $\begin{array}{l}52 \\
17 \\
17 \\
16 \\
56\end{array}$ & $\begin{array}{l}8 \\
8 \\
8 \\
8 \\
8\end{array}$ & $\begin{array}{l}861 \\
778 \\
778 \\
989 \\
827\end{array}$ & $\begin{array}{l}834 \\
804 \\
804 \\
963 \\
852\end{array}$ & $\begin{array}{l}27 \\
26 \\
26 \\
26 \\
25\end{array}$ \\
\hline $\begin{array}{r}99 \\
-47 \\
-12 \\
16 \\
6\end{array}$ & $\begin{array}{r}-62 \\
88 \\
-9 \\
89 \\
48\end{array}$ & $\begin{array}{r}42 \\
6 \\
39 \\
52 \\
41\end{array}$ & $\begin{array}{r}54 \\
52 \\
15 \\
8 \\
16\end{array}$ & $\begin{array}{l}8 \\
8 \\
8 \\
8 \\
8\end{array}$ & $\begin{array}{l}740 \\
915 \\
786 \\
873 \\
765\end{array}$ & $\begin{array}{l}765 \\
940 \\
810 \\
849 \\
789\end{array}$ & $\begin{array}{l}25 \\
25 \\
25 \\
24 \\
24\end{array}$ \\
\hline $\begin{array}{r}58 \\
-13 \\
-49 \\
-45 \\
86\end{array}$ & $\begin{array}{r}-2 \\
-87 \\
21 \\
-53 \\
20\end{array}$ & $\begin{array}{l}42 \\
47 \\
38 \\
44 \\
12\end{array}$ & $\begin{array}{l}55 \\
59 \\
18 \\
62 \\
20\end{array}$ & $\begin{array}{l}8 \\
8 \\
8 \\
8 \\
8\end{array}$ & $\begin{array}{l}748 \\
708 \\
765 \\
738 \\
819\end{array}$ & $\begin{array}{l}772 \\
684 \\
789 \\
715 \\
842\end{array}$ & $\begin{array}{l}24 \\
24 \\
24 \\
23 \\
23\end{array}$ \\
\hline $\begin{array}{r}-6 \\
-16 \\
84 \\
-7 \\
-42\end{array}$ & $\begin{array}{r}-1 \\
-21 \\
82 \\
-10 \\
-82\end{array}$ & $\begin{array}{r}45 \\
4 \\
36 \\
14 \\
8\end{array}$ & $\begin{array}{l}56 \\
62 \\
59 \\
60 \\
44\end{array}$ & $\begin{array}{l}8 \\
8 \\
8 \\
8 \\
8\end{array}$ & $\begin{array}{l}687 \\
894 \\
836 \\
844 \\
888\end{array}$ & $\begin{array}{l}664 \\
872 \\
858 \\
822 \\
866\end{array}$ & $\begin{array}{l}23 \\
22 \\
22 \\
22 \\
22\end{array}$ \\
\hline $\begin{array}{r}-93 \\
41 \\
58 \\
-74 \\
97\end{array}$ & $\begin{array}{r}-40 \\
30 \\
-87 \\
-22 \\
18\end{array}$ & $\begin{array}{l}54 \\
20 \\
28 \\
45 \\
52\end{array}$ & $\begin{array}{l}24 \\
12 \\
56 \\
55 \\
37\end{array}$ & $\begin{array}{l}8 \\
8 \\
8 \\
8 \\
8\end{array}$ & $\begin{array}{l}964 \\
877 \\
856 \\
716 \\
914\end{array}$ & $\begin{array}{l}943 \\
856 \\
877 \\
737 \\
893\end{array}$ & $\begin{array}{l}21 \\
21 \\
21 \\
21 \\
21\end{array}$ \\
\hline $\begin{array}{r}-6 \\
-73 \\
81 \\
-5 \\
86\end{array}$ & $\begin{array}{r}-90 \\
-35 \\
-90 \\
38 \\
-9\end{array}$ & $\begin{array}{l}53 \\
34 \\
16 \\
43 \\
49\end{array}$ & $\begin{array}{r}62 \\
8 \\
30 \\
53 \\
30\end{array}$ & $\begin{array}{l}8 \\
8 \\
8 \\
8 \\
8\end{array}$ & $\begin{array}{l}776 \\
897 \\
790 \\
724 \\
889\end{array}$ & $\begin{array}{l}796 \\
877 \\
810 \\
744 \\
909\end{array}$ & $\begin{array}{l}20 \\
20 \\
20 \\
20 \\
20\end{array}$ \\
\hline $\begin{array}{r}-33 \\
-27 \\
-1 \\
-7 \\
-51\end{array}$ & $\begin{array}{r}55 \\
-66 \\
28 \\
32 \\
-82\end{array}$ & $\begin{array}{l}22 \\
31 \\
55 \\
14 \\
10\end{array}$ & $\begin{array}{r}8 \\
14 \\
47 \\
9 \\
42\end{array}$ & $\begin{array}{l}8 \\
8 \\
8 \\
8 \\
8\end{array}$ & $\begin{array}{l}929 \\
816 \\
893 \\
936 \\
879\end{array}$ & $\begin{array}{l}910 \\
835 \\
912 \\
917 \\
860\end{array}$ & $\begin{array}{l}19 \\
19 \\
19 \\
19 \\
19\end{array}$ \\
\hline
\end{tabular}


Appendix D.--Absolute differences between mode1-calculated and observed heads (residuals) for

model calibration--Continued

\begin{tabular}{|c|c|c|c|c|c|c|c|}
\hline \multirow{2}{*}{$\begin{array}{l}\text { Percent } \\
\text { displacement } \\
\text { from center } \\
\text { to edge of } \\
\text { cell in y- } \\
\text { direction }\end{array}$} & \multirow{2}{*}{$\begin{array}{l}\text { Percent } \\
\text { displacement } \\
\text { from center } \\
\text { to edge of } \\
\text { cell in } x- \\
\text { direction }\end{array}$} & \multicolumn{3}{|c|}{ Cell Location } & \multirow{2}{*}{$\begin{array}{l}\text { Model } \\
\text { calculated } \\
\text { head }\end{array}$} & \multirow{2}{*}{$\begin{array}{l}\text { Modian of } \\
\text { measured } \\
\text { heads, } \\
1971-80\end{array}$} & \multirow{2}{*}{$\begin{array}{l}\text { Difference } \\
\text { between model } \\
\text { calculated and } \\
\text { measured heads }\end{array}$} \\
\hline & & Row & Column & $\begin{array}{l}\text { Model } \\
\text { layer }\end{array}$ & & & \\
\hline $\begin{array}{r}-14 \\
63 \\
76 \\
38 \\
65\end{array}$ & $\begin{array}{r}76 \\
56 \\
-72 \\
-84 \\
84\end{array}$ & $\begin{array}{r}33 \\
50 \\
53 \\
8 \\
18\end{array}$ & $\begin{array}{r}14 \\
55 \\
5 \\
18 \\
40\end{array}$ & $\begin{array}{l}8 \\
8 \\
8 \\
8 \\
8\end{array}$ & $\begin{array}{l}810 \\
815 \\
707 \\
854 \\
817\end{array}$ & $\begin{array}{l}829 \\
796 \\
726 \\
835 \\
798\end{array}$ & $\begin{array}{l}19 \\
19 \\
18 \\
19 \\
19\end{array}$ \\
\hline $\begin{array}{r}91 \\
-64 \\
-19 \\
-57 \\
-18\end{array}$ & $\begin{array}{r}-81 \\
62 \\
-14 \\
-61 \\
-24\end{array}$ & $\begin{array}{l}24 \\
27 \\
24 \\
50 \\
53\end{array}$ & $\begin{array}{l}61 \\
15 \\
58 \\
60 \\
13\end{array}$ & $\begin{array}{l}8 \\
8 \\
8 \\
8 \\
8\end{array}$ & $\begin{array}{l}802 \\
814 \\
853 \\
741 \\
944\end{array}$ & $\begin{array}{l}821 \\
832 \\
871 \\
723 \\
926\end{array}$ & $\begin{array}{l}19 \\
18 \\
18 \\
18 \\
18\end{array}$ \\
\hline $\begin{array}{r}35 \\
-87 \\
-66 \\
38 \\
-10\end{array}$ & $\begin{array}{r}-31 \\
-6 \\
62 \\
65 \\
17\end{array}$ & $\begin{array}{l}50 \\
19 \\
54 \\
42 \\
29\end{array}$ & $\begin{array}{l}12 \\
12 \\
31 \\
53 \\
47\end{array}$ & $\begin{array}{l}8 \\
8 \\
8 \\
8 \\
8\end{array}$ & $\begin{array}{l}909 \\
878 \\
952 \\
729 \\
750\end{array}$ & $\begin{array}{l}891 \\
896 \\
934 \\
747 \\
732\end{array}$ & $\begin{array}{l}18 \\
18 \\
18 \\
18 \\
18\end{array}$ \\
\hline $\begin{array}{r}-6 \\
56 \\
-14 \\
-61 \\
-40\end{array}$ & $\begin{array}{r}-73 \\
14 \\
86 \\
34 \\
74\end{array}$ & $\begin{array}{l}53 \\
52 \\
38 \\
23 \\
28\end{array}$ & $\begin{array}{l}61 \\
56 \\
41 \\
23 \\
42\end{array}$ & $\begin{array}{l}8 \\
8 \\
8 \\
8 \\
8\end{array}$ & $\begin{array}{l}781 \\
823 \\
773 \\
716 \\
702\end{array}$ & $\begin{array}{l}798 \\
840 \\
756 \\
733 \\
685\end{array}$ & $\begin{array}{l}17 \\
17 \\
17 \\
17 \\
17\end{array}$ \\
\hline $\begin{array}{r}39 \\
8 \\
-19 \\
87 \\
81\end{array}$ & $\begin{array}{r}-70 \\
5 \\
97 \\
20 \\
13\end{array}$ & $\begin{array}{l}15 \\
17 \\
53 \\
52 \\
50\end{array}$ & $\begin{array}{l}15 \\
17 \\
12 \\
31 \\
19\end{array}$ & $\begin{array}{l}8 \\
8 \\
8 \\
8 \\
8\end{array}$ & $\begin{array}{r}850 \\
823 \\
930 \\
933 \\
916\end{array}$ & $\begin{array}{l}867 \\
840 \\
814 \\
917 \\
900\end{array}$ & $\begin{array}{l}17 \\
17 \\
16 \\
16 \\
16\end{array}$ \\
\hline $\begin{array}{r}-4 \\
-4 \\
-94 \\
-69 \\
97\end{array}$ & $\begin{array}{r}22 \\
0 \\
72 \\
-37 \\
-8\end{array}$ & $\begin{array}{l}53 \\
46 \\
48 \\
30 \\
22\end{array}$ & $\begin{array}{l}60 \\
25 \\
33 \\
15 \\
34\end{array}$ & $\begin{array}{l}8 \\
8 \\
8 \\
8 \\
8\end{array}$ & $\begin{array}{l}786 \\
810 \\
871 \\
807 \\
755\end{array}$ & $\begin{array}{l}802 \\
795 \\
886 \\
822 \\
770\end{array}$ & $\begin{array}{l}16 \\
15 \\
15 \\
15 \\
15\end{array}$ \\
\hline $\begin{array}{l}-31 \\
-52 \\
-42 \\
-81 \\
-49\end{array}$ & $\begin{array}{r}-78 \\
-69 \\
88 \\
10 \\
80\end{array}$ & $\begin{array}{l}12 \\
39 \\
53 \\
29 \\
56\end{array}$ & $\begin{array}{l}38 \\
12 \\
54 \\
43 \\
30\end{array}$ & $\begin{array}{l}8 \\
8 \\
8 \\
8 \\
8\end{array}$ & $\begin{array}{l}849 \\
811 \\
851 \\
713 \\
963\end{array}$ & $\begin{array}{l}864 \\
797 \\
865 \\
699 \\
949\end{array}$ & $\begin{array}{l}15 \\
14 \\
14 \\
14 \\
14\end{array}$ \\
\hline $\begin{array}{r}22 \\
-98 \\
94 \\
34 \\
-46\end{array}$ & $\begin{array}{r}-98 \\
-8 \\
-18 \\
-99 \\
91\end{array}$ & $\begin{array}{l}12 \\
51 \\
11 \\
34 \\
34\end{array}$ & $\begin{array}{l}15 \\
39 \\
21 \\
11 \\
15\end{array}$ & $\begin{array}{l}8 \\
8 \\
8 \\
8 \\
8\end{array}$ & $\begin{array}{l}852 \\
904 \\
832 \\
860 \\
798\end{array}$ & $\begin{array}{l}866 \\
890 \\
818 \\
846 \\
811\end{array}$ & $\begin{array}{l}14 \\
14 \\
14 \\
14 \\
13\end{array}$ \\
\hline $\begin{array}{r}54 \\
-47 \\
-5 \\
62 \\
38\end{array}$ & $\begin{array}{r}-55 \\
42 \\
13 \\
2 \\
-26\end{array}$ & $\begin{array}{l}11 \\
25 \\
15 \\
10 \\
28\end{array}$ & $\begin{array}{l}16 \\
12 \\
58 \\
31 \\
43\end{array}$ & $\begin{array}{l}8 \\
8 \\
8 \\
8 \\
8\end{array}$ & $\begin{array}{l}847 \\
869 \\
892 \\
853 \\
715\end{array}$ & $\begin{array}{l}860 \\
856 \\
879 \\
840 \\
702\end{array}$ & $\begin{array}{l}13 \\
13 \\
13 \\
13 \\
13\end{array}$ \\
\hline $\begin{array}{r}-39 \\
4 \\
1 \\
-64 \\
-32\end{array}$ & $\begin{array}{r}35 \\
31 \\
32 \\
-15 \\
75\end{array}$ & $\begin{array}{l}13 \\
26 \\
41 \\
27 \\
42\end{array}$ & $\begin{array}{l}54 \\
58 \\
48 \\
58 \\
52\end{array}$ & $\begin{array}{l}8 \\
8 \\
8 \\
8 \\
8\end{array}$ & $\begin{array}{l}802 \\
851 \\
724 \\
850 \\
716\end{array}$ & $\begin{array}{l}914 \\
863 \\
712 \\
862 \\
728\end{array}$ & $\begin{array}{l}12 \\
12 \\
12 \\
12 \\
12\end{array}$ \\
\hline $\begin{array}{r}97 \\
14 \\
-50 \\
-23 \\
52\end{array}$ & $\begin{array}{r}-46 \\
10 \\
-63 \\
-60 \\
-51\end{array}$ & $\begin{array}{l}32 \\
44 \\
54 \\
11 \\
56\end{array}$ & $\begin{array}{l}10 \\
30 \\
52 \\
31 \\
45\end{array}$ & $\begin{array}{l}8 \\
8 \\
8 \\
8 \\
8\end{array}$ & $\begin{array}{l}882 \\
787 \\
869 \\
842 \\
880\end{array}$ & $\begin{array}{l}870 \\
775 \\
881 \\
830 \\
878\end{array}$ & $\begin{array}{l}12 \\
12 \\
12 \\
12 \\
12\end{array}$ \\
\hline $\begin{array}{r}81 \\
36 \\
-61 \\
76 \\
0\end{array}$ & $\begin{array}{r}-11 \\
41 \\
87 \\
58 \\
-20\end{array}$ & $\begin{array}{r}34 \\
17 \\
33 \\
12 \\
4\end{array}$ & $\begin{array}{l}18 \\
10 \\
16 \\
54 \\
57\end{array}$ & $\begin{array}{l}8 \\
8 \\
8 \\
8 \\
8\end{array}$ & $\begin{array}{l}781 \\
914 \\
786 \\
808 \\
817\end{array}$ & $\begin{array}{l}792 \\
903 \\
797 \\
919 \\
906\end{array}$ & $\begin{array}{l}11 \\
11 \\
11 \\
11 \\
11\end{array}$ \\
\hline
\end{tabular}


Appendix D.--Absolute differences between model-calculated and observed heads (residuals) for

model calibration--Continued

\begin{tabular}{|c|c|c|c|c|c|c|c|}
\hline \multirow{2}{*}{$\begin{array}{l}\text { Percent } \\
\text { displacement } \\
\text { from center } \\
\text { to edge of } \\
\text { cell in y- } \\
\text { direction }\end{array}$} & \multirow{2}{*}{$\begin{array}{l}\text { Percent } \\
\text { displacement } \\
\text { from center } \\
\text { to edge of } \\
\text { cell in } x- \\
\text { direction }\end{array}$} & \multicolumn{3}{|c|}{ Cell Location } & \multirow{2}{*}{$\begin{array}{l}\text { Model } \\
\text { calculated } \\
\text { head }\end{array}$} & \multirow{2}{*}{$\begin{array}{l}\text { Median of } \\
\text { measured } \\
\text { heads, } \\
1971-80\end{array}$} & \multirow{2}{*}{$\begin{array}{l}\text { Difference } \\
\text { between model } \\
\text { calculated and } \\
\text { measured heads }\end{array}$} \\
\hline & & Row & Column & $\begin{array}{l}\text { Model } \\
\text { layer }\end{array}$ & & & \\
\hline $\begin{array}{r}-83 \\
-95 \\
-33 \\
79 \\
-85\end{array}$ & $\begin{array}{l}-70 \\
-77 \\
-51 \\
-18 \\
-91\end{array}$ & $\begin{array}{l}36 \\
12 \\
34 \\
37 \\
12\end{array}$ & $\begin{array}{l}13 \\
34 \\
12 \\
31 \\
56\end{array}$ & $\begin{array}{l}8 \\
8 \\
8 \\
8 \\
8\end{array}$ & $\begin{array}{l}818 \\
837 \\
842 \\
726 \\
917\end{array}$ & $\begin{array}{l}808 \\
847 \\
832 \\
716 \\
927\end{array}$ & $\begin{array}{l}10 \\
10 \\
10 \\
10 \\
10\end{array}$ \\
\hline $\begin{array}{r}38 \\
-33 \\
66 \\
65 \\
77\end{array}$ & $\begin{array}{r}84 \\
-73 \\
11 \\
26 \\
-85\end{array}$ & $\begin{array}{r}28 \\
41 \\
5 \\
18 \\
54\end{array}$ & $\begin{array}{l}15 \\
35 \\
59 \\
18 \\
23\end{array}$ & $\begin{array}{l}8 \\
8 \\
8 \\
8 \\
8\end{array}$ & $\begin{array}{l}811 \\
763 \\
924 \\
812 \\
966\end{array}$ & $\begin{array}{l}801 \\
753 \\
934 \\
822 \\
956\end{array}$ & $\begin{array}{l}10 \\
10 \\
10 \\
10 \\
10\end{array}$ \\
\hline $\begin{array}{r}89 \\
-21 \\
20 \\
57 \\
-43\end{array}$ & $\begin{array}{r}44 \\
-41 \\
-8 \\
-84 \\
55\end{array}$ & $\begin{array}{l}15 \\
33 \\
11 \\
51 \\
11\end{array}$ & $\begin{array}{l}57 \\
55 \\
51 \\
34 \\
17\end{array}$ & $\begin{array}{l}8 \\
8 \\
8 \\
8 \\
8\end{array}$ & $\begin{array}{l}898 \\
833 \\
900 \\
916 \\
841\end{array}$ & $\begin{array}{l}888 \\
843 \\
909 \\
907 \\
850\end{array}$ & $\begin{array}{r}10 \\
10 \\
9 \\
9 \\
9\end{array}$ \\
\hline $\begin{array}{r}-36 \\
30 \\
-24 \\
76 \\
1\end{array}$ & $\begin{array}{r}76 \\
-15 \\
-17 \\
-95 \\
-8\end{array}$ & $\begin{array}{l}15 \\
45 \\
35 \\
53 \\
49\end{array}$ & $\begin{array}{r}37 \\
14 \\
8 \\
18 \\
49\end{array}$ & $\begin{array}{l}8 \\
8 \\
8 \\
8 \\
8\end{array}$ & $\begin{array}{l}830 \\
725 \\
893 \\
958 \\
840\end{array}$ & $\begin{array}{l}821 \\
716 \\
884 \\
950 \\
832\end{array}$ & $\begin{array}{l}9 \\
9 \\
9 \\
8 \\
8\end{array}$ \\
\hline $\begin{array}{r}71 \\
94 \\
-61 \\
-26 \\
17\end{array}$ & $\begin{array}{r}64 \\
88 \\
74 \\
-81 \\
10\end{array}$ & $\begin{array}{r}13 \\
52 \\
6 \\
15 \\
56\end{array}$ & $\begin{array}{l}29 \\
54 \\
40 \\
51 \\
36\end{array}$ & $\begin{array}{l}8 \\
8 \\
8 \\
8 \\
8\end{array}$ & $\begin{array}{l}810 \\
845 \\
888 \\
867 \\
936\end{array}$ & $\begin{array}{l}818 \\
853 \\
896 \\
875 \\
928\end{array}$ & $\begin{array}{l}8 \\
8 \\
8 \\
8 \\
8\end{array}$ \\
\hline $\begin{array}{r}-72 \\
83 \\
8 \\
-7 \\
-76\end{array}$ & $\begin{array}{r}-15 \\
46 \\
-81 \\
-80 \\
55\end{array}$ & $\begin{array}{r}20 \\
9 \\
42 \\
19 \\
48\end{array}$ & $\begin{array}{l}32 \\
46 \\
40 \\
56 \\
49\end{array}$ & $\begin{array}{l}8 \\
8 \\
8 \\
8 \\
8\end{array}$ & $\begin{array}{l}769 \\
892 \\
780 \\
884 \\
817\end{array}$ & $\begin{array}{l}777 \\
900 \\
788 \\
892 \\
809\end{array}$ & $\begin{array}{l}8 \\
8 \\
8 \\
8 \\
8\end{array}$ \\
\hline $\begin{array}{r}-27 \\
21 \\
-64 \\
58 \\
-95\end{array}$ & $\begin{array}{r}8 \\
-68 \\
73 \\
76 \\
-66\end{array}$ & $\begin{array}{l}31 \\
16 \\
17 \\
39 \\
50\end{array}$ & $\begin{array}{r}59 \\
59 \\
35 \\
9 \\
42\end{array}$ & $\begin{array}{l}8 \\
8 \\
8 \\
8 \\
8\end{array}$ & $\begin{array}{l}839 \\
872 \\
805 \\
855 \\
885\end{array}$ & $\begin{array}{l}831 \\
880 \\
813 \\
848 \\
878\end{array}$ & $\begin{array}{l}8 \\
8 \\
8 \\
7 \\
7\end{array}$ \\
\hline $\begin{array}{r}-38 \\
-42 \\
61 \\
99 \\
42\end{array}$ & $\begin{array}{r}58 \\
-86 \\
43 \\
-70 \\
60\end{array}$ & $\begin{array}{l}55 \\
18 \\
20 \\
52 \\
10\end{array}$ & $\begin{array}{l}40 \\
55 \\
48 \\
29 \\
28\end{array}$ & $\begin{array}{l}8 \\
8 \\
8 \\
8 \\
8\end{array}$ & $\begin{array}{l}921 \\
886 \\
828 \\
936 \\
848\end{array}$ & $\begin{array}{l}914 \\
893 \\
835 \\
929 \\
842\end{array}$ & $\begin{array}{l}7 \\
7 \\
7 \\
7 \\
6\end{array}$ \\
\hline $\begin{array}{r}50 \\
-24 \\
69 \\
-16 \\
-93\end{array}$ & $\begin{array}{r}26 \\
3 \\
68 \\
93 \\
13\end{array}$ & $\begin{array}{l}29 \\
49 \\
49 \\
21 \\
56\end{array}$ & $\begin{array}{l}60 \\
40 \\
59 \\
15 \\
38\end{array}$ & $\begin{array}{l}8 \\
8 \\
8 \\
8 \\
8\end{array}$ & $\begin{array}{l}821 \\
878 \\
732 \\
829 \\
924\end{array}$ & $\begin{array}{l}815 \\
872 \\
726 \\
823 \\
918\end{array}$ & $\begin{array}{l}6 \\
6 \\
6 \\
6 \\
6\end{array}$ \\
\hline $\begin{array}{r}41 \\
84 \\
63 \\
-66 \\
34\end{array}$ & $\begin{array}{r}95 \\
-51 \\
23 \\
-29 \\
-35\end{array}$ & $\begin{array}{l}16 \\
36 \\
21 \\
54 \\
52\end{array}$ & $\begin{array}{l}29 \\
12 \\
52 \\
49 \\
60\end{array}$ & $\begin{array}{l}8 \\
8 \\
8 \\
8 \\
8\end{array}$ & $\begin{array}{l}793 \\
835 \\
852 \\
888 \\
783\end{array}$ & $\begin{array}{l}799 \\
841 \\
858 \\
883 \\
778\end{array}$ & $\begin{array}{l}6 \\
6 \\
6 \\
5 \\
5\end{array}$ \\
\hline $\begin{array}{r}-3 \\
2 \\
92 \\
-13 \\
7\end{array}$ & $\begin{array}{r}99 \\
-61 \\
0 \\
71 \\
80\end{array}$ & $\begin{array}{r}41 \\
5 \\
52 \\
45 \\
28\end{array}$ & $\begin{array}{l}22 \\
57 \\
58 \\
13 \\
21\end{array}$ & $\begin{array}{l}8 \\
8 \\
8 \\
8 \\
8\end{array}$ & $\begin{array}{l}754 \\
931 \\
802 \\
700 \\
770\end{array}$ & $\begin{array}{l}749 \\
936 \\
797 \\
705 \\
766\end{array}$ & $\begin{array}{l}5 \\
5 \\
5 \\
5 \\
4\end{array}$ \\
\hline $\begin{array}{r}38 \\
66 \\
-90 \\
46 \\
54\end{array}$ & $\begin{array}{r}23 \\
46 \\
-64 \\
32 \\
13\end{array}$ & $\begin{array}{r}54 \\
27 \\
8 \\
19 \\
16\end{array}$ & $\begin{array}{l}33 \\
35 \\
55 \\
34 \\
14\end{array}$ & $\begin{array}{l}8 \\
8 \\
8 \\
8 \\
8\end{array}$ & $\begin{array}{l}947 \\
725 \\
936 \\
785 \\
861\end{array}$ & $\begin{array}{l}943 \\
721 \\
932 \\
789 \\
857\end{array}$ & $\begin{array}{l}4 \\
4 \\
4 \\
4 \\
4\end{array}$ \\
\hline
\end{tabular}


Appendix D.--Absoluate differences between model-calculated and observed heads (residuals) for model calibration--Continued

\begin{tabular}{|c|c|c|c|c|c|c|c|}
\hline \multirow{2}{*}{$\begin{array}{l}\text { Percent } \\
\text { displacement } \\
\text { from center } \\
\text { to edge of } \\
\text { cell in y- } \\
\text { direction }\end{array}$} & \multirow{2}{*}{$\begin{array}{l}\text { Percent } \\
\text { displacement } \\
\text { from center } \\
\text { to edge of } \\
\text { cell in } x- \\
\text { direction }\end{array}$} & \multicolumn{3}{|c|}{ Cell Location } & \multirow{2}{*}{$\begin{array}{l}\text { Model } \\
\text { calculated } \\
\text { hoad }\end{array}$} & \multirow{2}{*}{$\begin{array}{l}\text { Median of } \\
\text { moasured } \\
\text { heads, } \\
1971-80\end{array}$} & \multirow{2}{*}{$\begin{array}{l}\text { Difference } \\
\text { between model } \\
\text { calculated and } \\
\text { measured heads }\end{array}$} \\
\hline & & Row & Column & $\begin{array}{l}\text { Model } \\
\text { layer }\end{array}$ & & & \\
\hline $\begin{array}{r}42 \\
62 \\
-63 \\
30 \\
8\end{array}$ & $\begin{array}{r}15 \\
-12 \\
-56 \\
-24 \\
-86\end{array}$ & $\begin{array}{r}14 \\
9 \\
32 \\
53 \\
49\end{array}$ & $\begin{array}{l}31 \\
39 \\
11 \\
52 \\
14\end{array}$ & $\begin{array}{l}8 \\
8 \\
8 \\
8 \\
8\end{array}$ & $\begin{array}{l}813 \\
877 \\
869 \\
868 \\
883\end{array}$ & $\begin{array}{l}817 \\
873 \\
865 \\
864 \\
879\end{array}$ & $\begin{array}{l}4 \\
4 \\
4 \\
4 \\
4\end{array}$ \\
\hline $\begin{array}{r}92 \\
20 \\
0 \\
32 \\
33\end{array}$ & $\begin{array}{r}52 \\
-56 \\
9 \\
-24 \\
98\end{array}$ & $\begin{array}{r}44 \\
9 \\
15 \\
14 \\
6\end{array}$ & $\begin{array}{l}17 \\
57 \\
29 \\
38 \\
53\end{array}$ & $\begin{array}{l}8 \\
8 \\
8 \\
8 \\
8\end{array}$ & $\begin{array}{l}744 \\
932 \\
800 \\
840 \\
922\end{array}$ & $\begin{array}{l}748 \\
928 \\
804 \\
836 \\
918\end{array}$ & $\begin{array}{l}4 \\
4 \\
4 \\
4 \\
4\end{array}$ \\
\hline $\begin{array}{r}35 \\
47 \\
-80 \\
74 \\
0\end{array}$ & $\begin{array}{r}-32 \\
-21 \\
-19 \\
40 \\
-34\end{array}$ & $\begin{array}{r}13 \\
56 \\
4 \\
47 \\
6\end{array}$ & $\begin{array}{l}22 \\
50 \\
31 \\
36 \\
60\end{array}$ & $\begin{array}{l}8 \\
8 \\
8 \\
8 \\
8\end{array}$ & $\begin{array}{l}870 \\
863 \\
903 \\
862 \\
913\end{array}$ & $\begin{array}{l}811 \\
867 \\
906 \\
865 \\
916\end{array}$ & $\begin{array}{l}4 \\
4 \\
3 \\
3 \\
3\end{array}$ \\
\hline $\begin{array}{r}-63 \\
36 \\
52 \\
-7 \\
25\end{array}$ & $\begin{array}{r}79 \\
-56 \\
29 \\
-28 \\
75\end{array}$ & $\begin{array}{r}14 \\
27 \\
33 \\
25 \\
8\end{array}$ & $\begin{array}{l}28 \\
41 \\
33 \\
26 \\
53\end{array}$ & $\begin{array}{l}8 \\
8 \\
8 \\
8 \\
8\end{array}$ & $\begin{array}{l}806 \\
725 \\
728 \\
739 \\
926\end{array}$ & $\begin{array}{l}809 \\
722 \\
725 \\
741 \\
928\end{array}$ & $\begin{array}{l}3 \\
3 \\
2 \\
2 \\
2\end{array}$ \\
\hline $\begin{array}{r}-94 \\
98 \\
-44 \\
57 \\
-5\end{array}$ & $\begin{array}{r}-25 \\
29 \\
-56 \\
7 \\
-84\end{array}$ & $\begin{array}{r}27 \\
4 \\
12 \\
48 \\
20\end{array}$ & $\begin{array}{l}53 \\
59 \\
25 \\
46 \\
46\end{array}$ & $\begin{array}{l}8 \\
8 \\
8 \\
8 \\
8\end{array}$ & $\begin{array}{l}846 \\
919 \\
819 \\
842 \\
808\end{array}$ & $\begin{array}{l}848 \\
917 \\
821 \\
840 \\
810\end{array}$ & $\begin{array}{l}2 \\
2 \\
2 \\
2 \\
2\end{array}$ \\
\hline $\begin{array}{r}-82 \\
7 \\
51 \\
34 \\
93\end{array}$ & $\begin{array}{r}-81 \\
-23 \\
63 \\
-72 \\
-95\end{array}$ & $\begin{array}{l}28 \\
22 \\
53 \\
26 \\
14\end{array}$ & $\begin{array}{r}37 \\
11 \\
59 \\
9 \\
35\end{array}$ & $\begin{array}{l}8 \\
8 \\
8 \\
8 \\
8\end{array}$ & $\begin{array}{l}733 \\
891 \\
795 \\
907 \\
828\end{array}$ & $\begin{array}{l}731 \\
889 \\
797 \\
906 \\
827\end{array}$ & $\begin{array}{l}2 \\
2 \\
2 \\
1 \\
1\end{array}$ \\
\hline $\begin{array}{r}71 \\
1 \\
63 \\
25 \\
19\end{array}$ & $\begin{array}{r}-94 \\
-75 \\
32 \\
-47 \\
56\end{array}$ & $\begin{array}{l}13 \\
48 \\
50 \\
44 \\
19\end{array}$ & $\begin{array}{l}51 \\
58 \\
52 \\
15 \\
46\end{array}$ & $\begin{array}{l}8 \\
8 \\
8 \\
8 \\
8\end{array}$ & $\begin{array}{l}889 \\
717 \\
838 \\
745 \\
819\end{array}$ & $\begin{array}{l}890 \\
716 \\
837 \\
744 \\
818\end{array}$ & $\begin{array}{l}1 \\
1 \\
1 \\
1 \\
1\end{array}$ \\
\hline $\begin{array}{l}-59 \\
-90 \\
-16 \\
-57 \\
-68\end{array}$ & $\begin{array}{r}-42 \\
34 \\
-12 \\
-2 \\
86\end{array}$ & $\begin{array}{l}44 \\
11 \\
36 \\
21 \\
46\end{array}$ & $\begin{array}{r}48 \\
26 \\
30 \\
46 \\
8\end{array}$ & $\begin{array}{l}8 \\
8 \\
8 \\
8 \\
8\end{array}$ & $\begin{array}{l}746 \\
837 \\
734 \\
797 \\
719\end{array}$ & $\begin{array}{l}745 \\
836 \\
735 \\
796 \\
718\end{array}$ & $\begin{array}{l}1 \\
1 \\
1 \\
1 \\
1\end{array}$ \\
\hline $\begin{array}{r}22 \\
-49 \\
-59 \\
-39 \\
-48\end{array}$ & $\begin{array}{r}-71 \\
-37 \\
65 \\
34 \\
-22\end{array}$ & $\begin{array}{r}10 \\
8 \\
30 \\
49 \\
12\end{array}$ & $\begin{array}{l}37 \\
46 \\
52 \\
45 \\
21\end{array}$ & $\begin{array}{l}8 \\
8 \\
8 \\
8 \\
8\end{array}$ & $\begin{array}{l}864 \\
892 \\
826 \\
863 \\
813\end{array}$ & $\begin{array}{l}865 \\
891 \\
825 \\
863 \\
813\end{array}$ & $\begin{array}{l}1 \\
1 \\
1 \\
0 \\
0\end{array}$ \\
\hline $\begin{array}{r}-58 \\
-20 \\
-92 \\
21 \\
84\end{array}$ & $\begin{array}{r}-94 \\
4 \\
83 \\
73 \\
48\end{array}$ & $\begin{array}{r}54 \\
45 \\
8 \\
41 \\
11\end{array}$ & $\begin{array}{r}40 \\
9 \\
51 \\
12 \\
44\end{array}$ & $\begin{array}{l}8 \\
8 \\
8 \\
8 \\
8\end{array}$ & $\begin{array}{l}921 \\
697 \\
914 \\
790 \\
879\end{array}$ & $\begin{array}{l}921 \\
697 \\
914 \\
790 \\
879\end{array}$ & $\begin{array}{l}0 \\
0 \\
0 \\
0 \\
0\end{array}$ \\
\hline $\begin{array}{r}-34 \\
11 \\
-98 \\
-5 \\
-17\end{array}$ & $\begin{array}{r}10 \\
-11 \\
3 \\
95 \\
55\end{array}$ & $\begin{array}{r}33 \\
7 \\
39 \\
51 \\
50\end{array}$ & $\begin{array}{l}58 \\
58 \\
38 \\
15 \\
21\end{array}$ & $\begin{array}{l}8 \\
8 \\
9 \\
9 \\
9\end{array}$ & $\begin{array}{l}843 \\
932 \\
875 \\
966 \\
931\end{array}$ & $\begin{array}{l}843 \\
932 \\
778 \\
906 \\
880\end{array}$ & $\begin{array}{r}0 \\
0 \\
97 \\
60 \\
51\end{array}$ \\
\hline $\begin{array}{r}47 \\
-37 \\
55 \\
-81 \\
60\end{array}$ & $\begin{array}{r}24 \\
-40 \\
12 \\
-95 \\
10\end{array}$ & $\begin{array}{l}51 \\
35 \\
40 \\
29 \\
28\end{array}$ & $\begin{array}{l}22 \\
18 \\
48 \\
20 \\
36\end{array}$ & $\begin{array}{l}9 \\
9 \\
9 \\
9 \\
9\end{array}$ & $\begin{array}{l}978 \\
800 \\
761 \\
802 \\
853\end{array}$ & $\begin{array}{l}930 \\
844 \\
723 \\
839 \\
889\end{array}$ & $\begin{array}{l}48 \\
44 \\
38 \\
37 \\
36\end{array}$ \\
\hline
\end{tabular}


Appendix D.--Absolute differences between model-calculated and observed heads (residuals) for

model calibration--Continued

\begin{tabular}{|c|c|c|c|c|c|c|c|}
\hline \multirow{2}{*}{$\begin{array}{l}\text { Percent } \\
\text { displacement } \\
\text { from center } \\
\text { to edge of } \\
\text { cell in y- } \\
\text { direction }\end{array}$} & \multirow{2}{*}{$\begin{array}{l}\text { Percent } \\
\text { displacement } \\
\text { from center } \\
\text { to edge of } \\
\text { cell in } x- \\
\text { direction }\end{array}$} & \multicolumn{3}{|c|}{ Cell Location } & \multirow{2}{*}{$\begin{array}{l}\text { Model } \\
\text { calculated } \\
\text { head }\end{array}$} & \multirow{2}{*}{$\begin{array}{l}\text { Median of } \\
\text { measured } \\
\text { heads, } \\
1971-80\end{array}$} & \multirow{2}{*}{$\begin{array}{l}\text { Difference } \\
\text { between model } \\
\text { calculated and } \\
\text { measured heads }\end{array}$} \\
\hline & & Row & Column & $\begin{array}{l}\text { Model } \\
\text { layer }\end{array}$ & & & \\
\hline $\begin{array}{r}2 \\
28 \\
53 \\
-4 \\
-5\end{array}$ & $\begin{array}{r}80 \\
33 \\
-61 \\
-68 \\
21\end{array}$ & $\begin{array}{l}17 \\
46 \\
49 \\
35 \\
44\end{array}$ & $\begin{array}{l}52 \\
35 \\
17 \\
19 \\
18\end{array}$ & $\begin{array}{l}9 \\
9 \\
9 \\
9 \\
9\end{array}$ & $\begin{array}{l}887 \\
889 \\
915 \\
796 \\
788\end{array}$ & $\begin{array}{l}923 \\
854 \\
881 \\
828 \\
758\end{array}$ & $\begin{array}{l}36 \\
35 \\
34 \\
32 \\
30\end{array}$ \\
\hline $\begin{array}{r}6 \\
-49 \\
-39 \\
-64 \\
87\end{array}$ & $\begin{array}{r}0 \\
-72 \\
79 \\
-23 \\
-47\end{array}$ & $\begin{array}{l}19 \\
30 \\
38 \\
38 \\
19\end{array}$ & $\begin{array}{l}37 \\
11 \\
10 \\
15 \\
48\end{array}$ & $\begin{array}{l}9 \\
9 \\
9 \\
9 \\
9\end{array}$ & $\begin{array}{l}807 \\
883 \\
879 \\
809 \\
853\end{array}$ & $\begin{array}{l}836 \\
911 \\
853 \\
834 \\
828\end{array}$ & $\begin{array}{l}29 \\
28 \\
26 \\
25 \\
25\end{array}$ \\
\hline $\begin{array}{r}-17 \\
-56 \\
-63 \\
35 \\
-4\end{array}$ & $\begin{array}{l}-11 \\
-94 \\
-70 \\
-37 \\
-37\end{array}$ & $\begin{array}{l}17 \\
11 \\
36 \\
20 \\
54\end{array}$ & $\begin{array}{l}36 \\
44 \\
38 \\
17 \\
55\end{array}$ & $\begin{array}{l}9 \\
9 \\
9 \\
9 \\
9\end{array}$ & $\begin{array}{l}824 \\
888 \\
765 \\
827 \\
851\end{array}$ & $\begin{array}{l}848 \\
864 \\
741 \\
850 \\
873\end{array}$ & $\begin{array}{l}24 \\
24 \\
24 \\
23 \\
22\end{array}$ \\
\hline $\begin{array}{r}66 \\
-31 \\
-14 \\
99 \\
19\end{array}$ & $\begin{array}{l}-48 \\
46 \\
-67 \\
-77 \\
-34\end{array}$ & $\begin{array}{l}13 \\
49 \\
10 \\
54 \\
19\end{array}$ & $\begin{array}{l}35 \\
40 \\
19 \\
30 \\
35\end{array}$ & $\begin{array}{l}9 \\
9 \\
9 \\
9 \\
9\end{array}$ & $\begin{array}{l}852 \\
892 \\
836 \\
976 \\
797\end{array}$ & $\begin{array}{l}830 \\
870 \\
814 \\
954 \\
818\end{array}$ & $\begin{array}{l}22 \\
22 \\
22 \\
22 \\
21\end{array}$ \\
\hline $\begin{array}{r}-52 \\
-30 \\
35 \\
-43 \\
33\end{array}$ & $\begin{array}{r}68 \\
-84 \\
-9 \\
2 \\
37\end{array}$ & $\begin{array}{r}16 \\
21 \\
56 \\
21 \\
8\end{array}$ & $\begin{array}{l}34 \\
39 \\
51 \\
44 \\
16\end{array}$ & $\begin{array}{l}9 \\
9 \\
9 \\
9 \\
9\end{array}$ & $\begin{array}{l}822 \\
794 \\
876 \\
810 \\
843\end{array}$ & $\begin{array}{l}842 \\
813 \\
858 \\
794 \\
858\end{array}$ & $\begin{array}{l}20 \\
19 \\
18 \\
16 \\
15\end{array}$ \\
\hline $\begin{array}{r}-43 \\
-15 \\
7 \\
-37 \\
-14\end{array}$ & $\begin{array}{r}-83 \\
-39 \\
-43 \\
54 \\
-94\end{array}$ & $\begin{array}{l}21 \\
51 \\
11 \\
17 \\
49\end{array}$ & $\begin{array}{l}51 \\
31 \\
24 \\
38 \\
45\end{array}$ & $\begin{array}{l}9 \\
9 \\
9 \\
9 \\
9\end{array}$ & $\begin{array}{l}867 \\
935 \\
833 \\
835 \\
879\end{array}$ & $\begin{array}{l}852 \\
950 \\
818 \\
848 \\
866\end{array}$ & $\begin{array}{l}15 \\
15 \\
15 \\
13 \\
13\end{array}$ \\
\hline $\begin{array}{l}57 \\
84 \\
24 \\
56 \\
70\end{array}$ & $\begin{array}{r}41 \\
99 \\
-99 \\
40 \\
53\end{array}$ & $\begin{array}{l}22 \\
11 \\
15 \\
17 \\
17\end{array}$ & $\begin{array}{l}15 \\
40 \\
37 \\
34 \\
31\end{array}$ & $\begin{array}{l}9 \\
9 \\
9 \\
9 \\
9\end{array}$ & $\begin{array}{l}843 \\
881 \\
845 \\
825 \\
805\end{array}$ & $\begin{array}{l}856 \\
869 \\
857 \\
813 \\
817\end{array}$ & $\begin{array}{l}13 \\
12 \\
12 \\
12 \\
12\end{array}$ \\
\hline $\begin{array}{r}-34 \\
31 \\
-63 \\
-89 \\
-6\end{array}$ & $\begin{array}{r}-56 \\
54 \\
-52 \\
-67 \\
-17\end{array}$ & $\begin{array}{l}13 \\
18 \\
55 \\
48 \\
11\end{array}$ & $\begin{array}{l}52 \\
42 \\
40 \\
20 \\
15\end{array}$ & $\begin{array}{l}9 \\
9 \\
9 \\
9 \\
9\end{array}$ & $\begin{array}{l}903 \\
836 \\
930 \\
888 \\
857\end{array}$ & $\begin{array}{l}914 \\
847 \\
920 \\
879 \\
865\end{array}$ & $\begin{array}{r}11 \\
11 \\
10 \\
9 \\
8\end{array}$ \\
\hline $\begin{array}{r}94 \\
40 \\
-88 \\
-3 \\
-34\end{array}$ & $\begin{array}{l}99 \\
39 \\
60 \\
20 \\
80\end{array}$ & $\begin{array}{l}45 \\
13 \\
33 \\
21 \\
12\end{array}$ & $\begin{array}{r}31 \\
20 \\
9 \\
40 \\
16\end{array}$ & $\begin{array}{l}9 \\
9 \\
9 \\
9 \\
9\end{array}$ & $\begin{array}{l}827 \\
826 \\
905 \\
799 \\
848\end{array}$ & $\begin{array}{l}819 \\
818 \\
911 \\
805 \\
854\end{array}$ & $\begin{array}{l}8 \\
8 \\
6 \\
6 \\
6\end{array}$ \\
\hline $\begin{array}{r}-49 \\
83 \\
68 \\
-2 \\
-23\end{array}$ & $\begin{array}{r}-37 \\
28 \\
-56 \\
-52 \\
-19\end{array}$ & $\begin{array}{r}8 \\
9 \\
20 \\
14 \\
22\end{array}$ & $\begin{array}{l}46 \\
14 \\
43 \\
37 \\
12\end{array}$ & $\begin{array}{l}9 \\
9 \\
9 \\
9 \\
9\end{array}$ & $\begin{array}{l}890 \\
859 \\
818 \\
852 \\
885\end{array}$ & $\begin{array}{l}896 \\
865 \\
813 \\
847 \\
880\end{array}$ & $\begin{array}{l}6 \\
6 \\
5 \\
5 \\
5\end{array}$ \\
\hline $\begin{array}{r}-74 \\
-14 \\
34 \\
60 \\
70\end{array}$ & $\begin{array}{r}-36 \\
99 \\
-37 \\
91 \\
-37\end{array}$ & $\begin{array}{r}7 \\
10 \\
11 \\
11 \\
17\end{array}$ & $\begin{array}{l}39 \\
14 \\
45 \\
42 \\
17\end{array}$ & $\begin{array}{l}9 \\
9 \\
9 \\
9 \\
9\end{array}$ & $\begin{array}{l}880 \\
860 \\
890 \\
885 \\
836\end{array}$ & $\begin{array}{l}885 \\
864 \\
893 \\
888 \\
838\end{array}$ & $\begin{array}{l}5 \\
4 \\
3 \\
3 \\
2\end{array}$ \\
\hline $\begin{array}{r}-39 \\
-76 \\
-5 \\
-76 \\
82\end{array}$ & $\begin{array}{r}26 \\
64 \\
-89 \\
-96 \\
-78\end{array}$ & $\begin{array}{l}13 \\
11 \\
20 \\
52 \\
52\end{array}$ & $\begin{array}{l}55 \\
46 \\
58 \\
45 \\
39\end{array}$ & $\begin{array}{r}9 \\
9 \\
9 \\
10 \\
10\end{array}$ & $\begin{array}{l}920 \\
893 \\
890 \\
953 \\
965\end{array}$ & $\begin{array}{l}919 \\
892 \\
890 \\
866 \\
888\end{array}$ & $\begin{array}{r}1 \\
1 \\
0 \\
87 \\
77\end{array}$ \\
\hline
\end{tabular}


Appendix D.--Absolute differences between model-calculated and observed heads (residuals) for

model calibration--Continued

\begin{tabular}{|c|c|c|c|c|c|c|c|}
\hline \multirow{2}{*}{$\begin{array}{l}\text { Percent } \\
\text { displacement } \\
\text { from center } \\
\text { to edge of } \\
\text { cell in y- } \\
\text { direction }\end{array}$} & \multirow{2}{*}{$\begin{array}{l}\text { Percent } \\
\text { displacement } \\
\text { from center } \\
\text { to edge of } \\
\text { cell in } x- \\
\text { direction }\end{array}$} & \multicolumn{3}{|c|}{ Cell Location } & \multirow[b]{2}{*}{$\begin{array}{l}\text { Model } \\
\text { calculated } \\
\text { head }\end{array}$} & \multirow{2}{*}{$\begin{array}{l}\text { Modian of } \\
\text { measured } \\
\text { heads, } \\
1971-80\end{array}$} & \multirow{2}{*}{$\begin{array}{l}\text { Difference } \\
\text { between model } \\
\text { calculated and } \\
\text { measured heads }\end{array}$} \\
\hline & & Row & Column & $\begin{array}{l}\text { Model } \\
\text { layer }\end{array}$ & & & \\
\hline $\begin{array}{r}21 \\
28 \\
-14 \\
-79 \\
-54\end{array}$ & $\begin{array}{r}53 \\
-84 \\
92 \\
-28 \\
-71\end{array}$ & $\begin{array}{l}20 \\
28 \\
12 \\
30 \\
12\end{array}$ & $\begin{array}{l}49 \\
16 \\
38 \\
37 \\
25\end{array}$ & $\begin{array}{l}10 \\
10 \\
10 \\
10 \\
10\end{array}$ & $\begin{array}{l}900 \\
838 \\
888 \\
847 \\
830\end{array}$ & $\begin{array}{l}942 \\
874 \\
860 \\
834 \\
829\end{array}$ & $\begin{array}{l}42 \\
36 \\
28 \\
13 \\
10\end{array}$ \\
\hline $\begin{array}{r}56 \\
-57 \\
93 \\
-10 \\
33\end{array}$ & $\begin{array}{r}-54 \\
-2 \\
-95 \\
-51 \\
-90\end{array}$ & $\begin{array}{l}27 \\
21 \\
14 \\
15 \\
19\end{array}$ & $\begin{array}{l}19 \\
46 \\
35 \\
40 \\
12\end{array}$ & $\begin{array}{l}10 \\
10 \\
10 \\
10 \\
10\end{array}$ & $\begin{array}{l}854 \\
858 \\
874 \\
885 \\
918\end{array}$ & $\begin{array}{l}846 \\
864 \\
869 \\
883 \\
919\end{array}$ & $\begin{array}{l}8 \\
6 \\
5 \\
2 \\
1\end{array}$ \\
\hline $\begin{array}{l}61 \\
93 \\
-5\end{array}$ & $\begin{array}{l}-63 \\
-86 \\
-84\end{array}$ & $\begin{array}{l}20 \\
14 \\
20\end{array}$ & $\begin{array}{l}41 \\
42 \\
46\end{array}$ & $\begin{array}{l}10 \\
10 \\
10\end{array}$ & $\begin{array}{l}843 \\
883 \\
858\end{array}$ & $\begin{array}{l}843 \\
883 \\
858\end{array}$ & $\begin{array}{l}0 \\
0 \\
0\end{array}$ \\
\hline
\end{tabular}

